STEREOTYPES AND HUMAN RIGHTS LAW 



\title{
STEREOTYPES \\ AND HUMAN RIGHTS LAW
}

\author{
Edited by \\ Eva BREMS \\ Alexandra Timmer
}

intersentia

Cambridge - Antwerp - Portland 
Intersentia Ltd

Sheraton House | Castle Park

Cambridge | CB3 0AX | United Kingdom

Tel.: +441223 370170 | Fax: +44 1223370169

Email: mail@intersentia.co.uk

www.intersentia.com | www.intersentia.co.uk

Distribution for the UK and Ireland:

NBN International

Airport Business Centre, 10 Thornbury Road

Plymouth, PL6 7PP

United Kingdom

Tel: +44 1752202301 | Fax: +44 1752202331

Email: orders@nbninternational.com

Distribution for Europe and all other countries:

Intersentia Publishing nv

Groenstraat 31

2640 Mortsel

Belgium

Tel.: +32 36801550 | Fax: +32 36587121

Email: mail@intersentia.be

Distribution for the USA and Canada:

International Specialized Book Services

920 NE $58^{\text {th }}$ Ave Suite 300

Portland, OR 97213

USA

Tel.: +1 8009446190 (toll free) | Fax: +1 5032808832

Email: info@isbs.com

Stereotypes and Human Rights Law

(C) The editors and contributors severally 2016

The authors have asserted the right under the Copyright, Designs and Patents Act 1988, to be identified as authors of this work.

No part of this book may be reproduced, stored in a retrieval system, or transmitted, in any form, or by any means, without prior written permission from Intersentia, or as expressly permitted by law or under the terms agreed with the appropriate reprographic rights organisation. Enquiries concerning reproduction which may not be covered by the above should be addressed to Intersentia at the address above.

Cover image: Portefeuille des Maîtres du Bauhaus, Schlemmer Oskar (18881943) (C Centre Pompidou, MNAM-CCI, Dist. RMN-Grand Palais/Jean-Claude Planchet

ISBN 978-1-78068-368-3

D/2016/7849/48

NUR 828

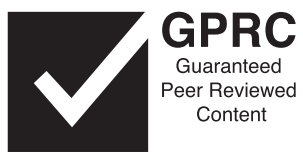

British Library Cataloguing in Publication Data. A catalogue record for this book is available from the British Library. 


\section{CONTENTS}

\section{Introduction}

Eva Brems and Alexandra Timmer........................

1. Stereotyping as a Human Rights Issue: Crosscutting Themes . . . . . . 2

2. Overview of the Volume .............................. 5

Building Momentum Towards Change. How the UN's Response to Stereotyping is Evolving

Simone Cusack ................................... 11

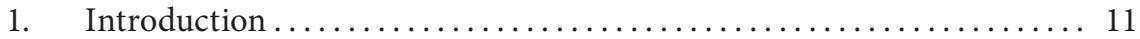

2. Key Developments in UN Responses to Stereotyping.............. 13

2.1. There is Greater Visibility of Stereotyping within the UN . ..... 14

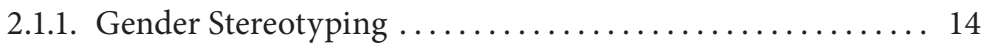

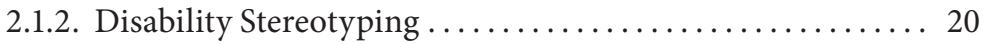

2.1.3. Other Types of Stereotyping ................. 24

2.2. Analysis of Gender Stereotyping is More Sophisticated ....... 26

2.2.1. The Language Used to Engage with Gender Stereotyping is More Nuanced .......................... 27

2.2.2. Analysis of the Impact of Stereotyping is More In-Depth. . 28

2.3. The OHCHR is Playing a Leadership Role on Stereotyping ..... . 30

3. Strategies for Strengthening UN Responses to Stereotyping ......... 31

3.1. Build Capacity to Understand and Identify Stereotypes

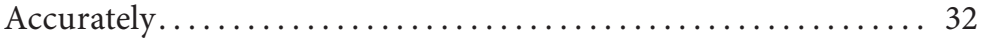

3.1.1. Failure to Identify Stereotypes Accurately........... 32

3.1.2. Build Capacity of UN Mechanisms .............. 33

3.2. Elaborate State Obligations Related to Stereotyping........... 34

3.2.1. Limited Guidance on State Obligations Related to Stereotyping $\ldots \ldots \ldots \ldots \ldots \ldots \ldots \ldots \ldots \ldots \ldots \ldots \ldots \ldots \ldots \ldots \ldots$

3.2.2. Elaborate State Obligations Related to Stereotyping...... 34

3.3. Highlight Good Practice Examples of Challenging Stereotyping. . 36

3.3.1. Limited Awareness of Effective Responses to Stereotyping . 36

3.3.2. Identify and Highlight Measures that are Bringing about

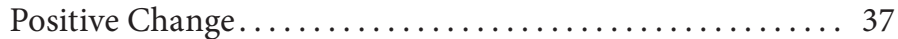

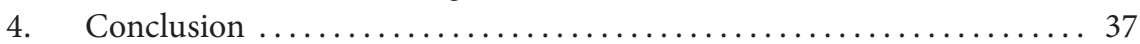


Gender Stereotyping in Domestic Violence Cases. An Analysis of the European Court of Human Rights' Jurisprudence

Lourdes Peroni and Alexandra Timmer..................... 39

1. The Conceptual and Legal Framework ..................... 40

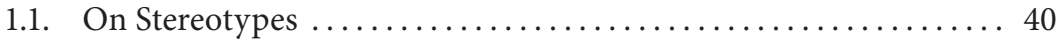

1.2. Gender Stereotypes as a Root Cause of Violence Against

Women in International Human Rights Law ............ 42

2. Naming and Contesting Gender Stereotypes in Domestic Violence Case Law ....................................... 48

2.1. Naming Gender Stereotypes and Exposing their Harms ....... 48

2.1.1. Women are (or Ought to be) Weak, Passive and Helpless ... 49

2.1.2. Women Ought to be Submissive................ 51

2.1.3. Women (Ought to) Endure Men's Aggressiveness or Violence (and Other Gender Stereotypes) ......... 54

2.1.4. Women are Financially Dependent............... 55

2.1.5. Women are Mothers and Homemakers (and Other Gender Stereotypes) ..................... 57

2.2. Contesting Gender Stereotypes ................... 61

2.2.1. Contesting Individuals' Stereotyping: States' Positive Obligations............................. 61

2.2.2. Contesting Gender Stereotyping by the State: Discrimination $\ldots \ldots \ldots \ldots \ldots \ldots \ldots \ldots \ldots \ldots \ldots \ldots \ldots$

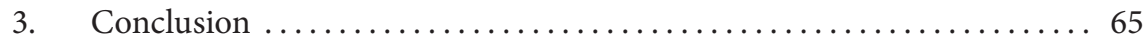

Gender Stereotyping in the Case Law of the Inter-American Court of Human Rights

Verónica UndurRaga .............................67 67

1. The Inter-American Human Rights System................. 68

2. Gender and Gender Stereotyping in the Inter-American Human

Rights System...................................... 69

2.1. The Cotton Field Case ............................. 70

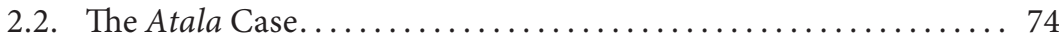

3. Some Common Approaches to Both Cases ..................... 77

4. Debunking Gender Stereotypes through Adjudication ............ 81

5. Separating the Wheat from the Chaff .................... 83

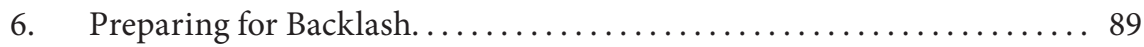




\section{'My Sense of Humanity Has Gone Down the Drain'. Stereotypes, Stigma and Sanism}

Michael Perlin ...................................... 95

1. How Stereotypes Limit Human Rights ..................... 97

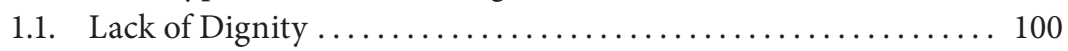

1.2. Stereotypes Contaminate Legislative Debate ............ 102

1.3. 'Hearts and Minds'................................. 104

1.4. Value of Test Cases............................. 106

1.5. Relationship to Other Sorts of Stigma and Stereotypes ....... 110

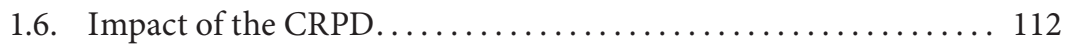

2. Therapeutic Jurisprudence ............................ 114

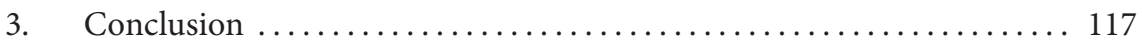

\section{Racial Stereotypes and Human Rights}

Mathias Möschel.................................. 119

1. Racial Stereotypes and Violence ...................... 121

1.1. In Relation to State-Organised Violence/Genocide.......... 121

1.2. Racially Motivated/Biased Violence by State or Public Actors ... 123

1.3. Racially Motivated/Biased Violence by Private Actors ....... 126

2. Racial Stereotypes in the Absence of Violence ................ 127

2.1. Racial Bias in Court Decisions ..................... 127

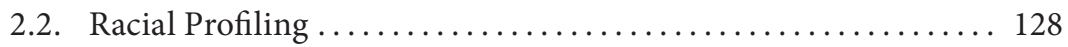

2.3. Racial Imagery or Depictions not Leading to Violence . . . . . . . 129

3. Specialised Human Rights Bodies Against Racism .............. 131

3.1. International Convention on the Elimination of All Forms

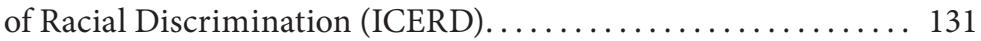

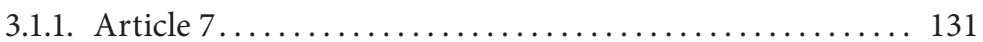

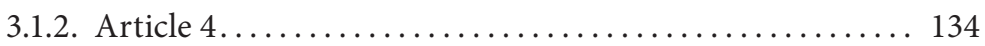

3.2. European Commission against Racism and Intolerance (ECRI) . 136 4. Fighting Racial Stereotypes through Human Rights in the Future?.. . 137

The Head of the Woman is the Man. The Failure to Address Gender Stereotypes in the Legal Procedures around the Dutch SGP

Rikki Holtma Aт. . . . . . . . . . . . . . . . . . . . . . . ........ 143

1. The SGP: its Origins and Principles, and the Political and Legal

Responses to its Discriminatory Policy.................. 146

1.1. The SGP: its Origins and Principles................... 146

1.2. The Position of the Dutch Government as Regards the SGP ... . 149

1.3. Legal Procedures Against the SGP and Against the Dutch State

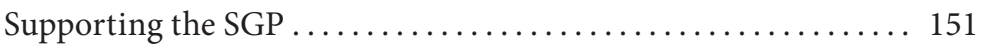


2. The Construction of the Legal Problem as an Issue of Unequal

Treatment of Women ............................... 154

2.1. Four Different Possibilities to Legally Address the SGP's Policy to Exclude Women from Political Participation............ 155

2.2. The Construction of the SGP's Policy as a Case of Unequal Treatment of Women............................. 159

2.3. The Impossibility of Justifying Discrimination Against Women with an Appeal to Traditional Gender Roles.............. 165

3. The Metaphors Used in the Justification Test in Sex-Equality Cases . . 167

3.1. The Disastrous Language of Conflicting Rights. . . . . . . . . . 167

3.2. Towards Using a Different Metaphor ............... 170

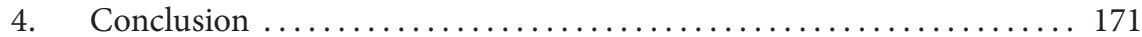

Gender Stereotyping in the Military. Insights From Court Cases

Rebecca Cook and Cornelia Weiss ............................ 175

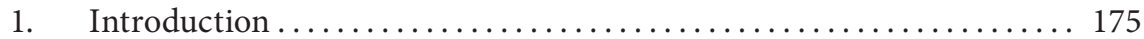

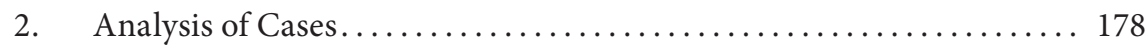

2.1. Exclusion Cases................................. 178

2.2. Unequal Treatment Cases....................... 188

2.3. Sexual Assault Cases ................................ 192

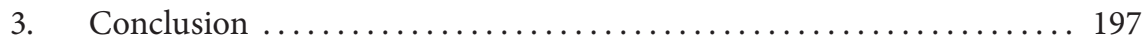




\title{
INTRODUCTION
}

\author{
Eva Brems and Alexandra Timmer
}

Stereotyping has emerged as a human rights law topic. Stereotypes assign certain roles and characteristics to a group. Examples include the notions that women are nurturing and weak, men combative and powerful, and gays promiscuous and unsuited to parenting. Such stereotypes can deeply impact the enjoyment of human rights. They reinforce inequality and discrimination. Several human rights treaties therefore mention that states are under an obligation to combat stereotyping. Examples include Article 5(a) of the Convention on the Elimination of All Forms of Discrimination against Women (CEDAW); Article 8(b) of the Convention on the Rights of Persons with Disabilities (CRPD); and Articles 12 and 14 of the Council of Europe Convention on preventing and combating violence against women and domestic violence (the Istanbul Convention). Increasingly, human rights courts and treaty bodies - including the European Court of Human Rights (ECtHR), the Inter-American Court of Human Rights (IACtHR), the CEDAW Committee, and the Committee on the Elimination of Racial Discrimination (CERD) - voice concerns about stereotyping and insist that states should not enforce harmful stereotypes.

Nevertheless, stereotypes have so far received little sustained consideration from human rights law scholars. The literature has largely been confined either to domestic borders (ie focusing on American equal protection law), ${ }^{1}$ or to single human rights treaties (typically CEDAW), ${ }^{2}$ or to a single ground (namely gender). The stereotyping concept is markedly further developed in the context of gender discrimination compared to other grounds of discrimination, raising the question how well the concept travels to other grounds. This volume is innovative by taking a broad view on the human rights dimensions of stereotyping. The book investigates different stereotyping grounds - namely race, gender, and disability -

eg Cary Franklin, 'The Anti-Stereotyping Principle in Constitutional Sex Discrimination Law' (2010) 85 New York University Law Review 83; Neil S Siegel and Reva B Siegel, 'Struck By Stereotype: Ruth Bader Ginsburg on Pregnancy Discrimination as Sex Discrimination' (2010) 59 Duke Law Journal 771.

2 eg Rebecca J Cook and Simone Cusack, Gender Stereotyping: Transnational Legal Perspectives (University of Pennsylvania Press 2010); Rikki Holtmaat, 'Article 5 CEDAW' in Marsha A Freeman, Christine Chinkin and Beate Rudolf (eds), The Convention on the Elimination of All Forms of Discrimination against Women: A Commentary (OUP 2012). 
as well as different human rights bodies and courts, including the UN system, the ECtHR and the IACtHR.

\section{STEREOTYPING AS A HUMAN RIGHTS ISSUE: CROSSCUTTING THEMES}

As a human rights issue, stereotyping raises several important crosscutting themes. We will discuss three of them below. The first theme is how to conceive of stereotypes, the second is how to distinguish harmful from acceptable stereotyping, and the third is the role of courts and treaty bodies in addressing stereotypes. These are all contested topics, which the authors in this volume address in different ways.

The first theme, how to conceive of stereotypes, is conceptual. There is extensive social psychology literature on this topic, ${ }^{3}$ but it remains an open question what conceptualisation is most useful in human rights law contexts. In their book entitled Gender Stereotyping: Transnational Legal Perspectives, Rebecca Cook and Simone Cusack have proposed the following definition of a stereotype: 'a generalized view or preconception of attributes or characteristics possessed by, or the roles that should be performed by, members of a particular group'. This definition, or something akin to it, is also used by several of the authors in the present volume focusing on gender and race stereotyping. ${ }^{5}$ Cook and Cusack's definition underlines that stereotypes can both be descriptive and normative in content. Often, the descriptive and the normative lie very close together, as in the 'women are homemakers' and 'women should be homemakers' stereotype. Moreover, the definition is neutral in the sense that it can encompass both positive and negative preconceptions. ${ }^{6}$ It would be a mistake to think, however, that only negative stereotypes - of the variety 'women are weak' or 'Roma are thieves' - have negative consequences. Positive stereotypes can be malignant too. ${ }^{7}$ Salient examples are the many benevolent yet patronising stereotypes about

3 Good introductions include Charles Stangor (ed), Stereotypes and Prejudice: Essential Readings (Psychology Press 2000); Todd D Nelson (ed), Handbook of Prejudice, Stereotyping and Discrimination (Psychology Press 2009); John F Dovidio et al (eds), The SAGE Handbook of Prejudice, Stereotyping and Discrimination (SAGE 2010).

$4 \quad$ Cook and Cusack (n 2) 9.

$5 \quad$ Cusack (ch 2); Cook and Weiss (ch 8); Möschel draws on a similar definition: 'beliefs about another group in such terms as personality traits, attributions, or behavioural descriptions' (ch 6); Peroni and Timmer simply conceive of stereotypes as 'beliefs about groups of people' (ch 3).

6 Not every author in this volume takes the same view, however. Perlin stresses that stereotypes typify in negative ways, and that, when applied to persons with disabilities, there is no evidence of positive stereotyping (see ch 5).

7 See eg Peter Glick and Susan T Fiske, 'An Ambivalent Alliance: Hostile and Benevolent Sexism as Complementary Justifications for Gender Inequality’ (2001) 56 American Psychologist 109; John T Jost and Aaron C Kay, 'Exposure to Benevolent Sexism and Complementary Gender 
women: when women are held to be nurturing, warm and caring, this serves to justify a system of patriarchy where men perform the leading roles and women the supportive ones.

Not all stereotyping can or should be eliminated, however. There are two main reasons for this, one legal and the other psychological. The legal reason is that law is inevitably based on classifications and generalisations. Equality scholars have long emphasised this. ${ }^{8}$ Classifications are usually based on stereotypes, as when the law prohibits people below a certain age to drive (the stereotype at issue is that children are reckless). Thus law cannot be purged from all stereotyping. The second reason is that, as an empirical psychological matter, all people stereotype. Stereotypes serve several psychological functions: they can both 'supplement an information-impoverished environment' and 'reduce the complexity of an information-rich environment'. In other words, stereotypes provide predictability. ${ }^{10}$ Another psychological function of stereotypes concerns our feelings about ourselves. Stereotyping is a 'self-image-maintenance' strategy. ${ }^{11}$

This brings us to the second crosscutting theme. As not all stereotyping can or need be eliminated, legal scholars and judges face the perennial difficulty of distinguishing between harmful and acceptable stereotyping. In her chapter, Verónica Undurraga calls this 'separating the wheat from the chaff'. ${ }^{12}$ Legal scholars seem to agree that identifying harmful stereotypes requires a form of contextual analysis. ${ }^{13}$ But there is no consensus as to what kind of contextual aspects courts should take into account. This comes as no surprise: not only is there no consensus in the scholarship, but the approach of national courts to the question of what makes stereotypes harmful also varies greatly. For example, the US Supreme Court regularly invalidates measures that are based on protective stereotyping (in other words: stereotyping that serves the purpose of ameliorating

Stereotypes: Consequences for Specific and Diffuse Forms of System Justification' (2005) 88 Journal of Personality and Social Psychology 498.

$8 \quad$ eg Joseph Tussman and Jacobus ten Broek, 'The Equal Protection of the Laws' (1949) 37 California Law Review 341, 343-344. See also more generally John H Ely, Democracy and Distrust: A Theory of Judicial Review (Harvard University Press 1980) 156 ('[s]tereotypes ... are the inevitable stuff of legislation'); Frederick Schauer, Profiles, Probabilities, and Stereotypes (Belknap Press 2006).

$9 \quad$ Charles Stangor and Mark Schaller, 'Stereotypes as Individual and Collective Representations' in Charles Stangor (ed), Stereotypes and Prejudice: Essential Readings (Psychology Press 2000) 74 .

$10 \quad$ Cook and Cusack (n 2) 14-15.

11 Steven Fein and Steven J Spencer, 'Prejudice as Self-Image Maintenance: Affirming the Self Through Derogating Others' in Charles Stangor (ed), Stereotypes and Prejudice: Essential Readings (Psychology Press 2000) 186.

12 See Undurraga (ch 4).

13 Alexandra Timmer, 'Judging Stereotypes: What the European Court of Human Rights Can Borrow from American and Canadian Equal Protection Law' (2015) 63 American Journal of Comparative Law 239, 279-281. 
the position of a disadvantaged group), whereas the Supreme Court of Canada is much more likely to approve such stereotyping. ${ }^{14}$

What does the challenge to distinguish harmful stereotypes entail, more specifically, in the framework of human rights law? Stereotypes become problematic when they operate to deny individuals their human rights. ${ }^{15}$ Thus, in human rights law, identifying harmful stereotyping requires identifying whether the application of a stereotype constitutes a human rights violation in itself, and/or whether the application of a stereotype is a contributing factor in a human rights violation. An example of the first scenario is when a state does not accord fathers parental leave, because mothers are supped to take care of children. This scenario was at issue in the ECtHR case of Konstantin Markin $v$ Russia. ${ }^{16}$ An example of the second scenario, where stereotyping was a factor that contributed to a human rights violation, can be found in the ECtHR case of V.C. $v$ Slovakia, concerning the forced sterilisation of a Roma woman. ${ }^{17}$ The physician of V.C. had noted in her medical file 'patient is of Roma origin'. ${ }^{18}$ Stereotypes about the high birth-rate of Roma women, coupled to the stereotype that Roma want to live of social benefits, ${ }^{19}$ might have influenced the doctor in performing the forced sterilisation - which in turn is a violation of the prohibition of degrading treatment and the right to private and family life (Articles 3 and 8 ECHR).

This raises the third and last crosscutting theme, namely what courts (including both regional human rights courts and national courts) and treaty bodies can and should do to address harmful stereotypes. The first step, authors in this volume agree, is that courts should name stereotypes properly in their legal reasoning. ${ }^{20}$ Naming stereotyping entails identifying what beliefs about groups of people are at play in a case, and it also entails exposing what harms these beliefs do. Naming stereotypes makes them visible. Naming stereotypes is a prerequisite for changing them. The second step is that courts and treaty bodies should clarify - as much as possible - the state's obligations as regards stereotyping. In the first place state obligations are negative in character: states ought to refrain from legislating or acting on the basis of harmful stereotypes. But that is not all. States have also a more proactive role to play. States' positive obligation to address stereotypes regards the question what role states can play in preventing officials from relying on harmful stereotypes and in ensuring that individuals do not stereotype each other in harmful ways.

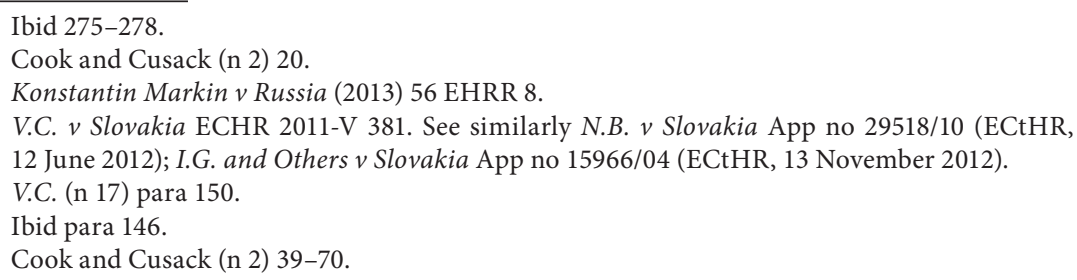




\section{OVERVIEW OF THE VOLUME}

The institutional framework that has been created for the international monitoring of states' respect for human rights is pluriform and fragmented. The first three chapters of the volume single out for separate analysis the three layers or fora that can be considered to be leading in terms of setting standards for human rights law overall. These are the United Nations Treaty Bodies (Chapter 2), the European Court of Human Rights (Chapter 3) and the Inter-American Court of Human Rights (Chapter 4).

In human rights treaty provisions, references to stereotyping are scarce. They can be found neither in the European Convention on Human Rights and its additional protocols, nor in the American Convention on Human Rights and its protocols. Yet, among the United Nations human rights treaties that address specific target groups, two explicitly include a reference to stereotypes. In that respect it is interesting to note that the CEDAW, which was adopted in 1979, is the first treaty of this type, and the CRPD, which was adopted in 2006, is the most recent one. Moreover, the provision on stereotyping in the CRPD is more elaborate than that in CEDAW. Even though the concept of stereotyping has not prominently risen to the forefront in the intervening decades, this shows that combatting harmful stereotypes has for a long time been considered a relevant aspect of the United Nations agenda for the protection of the human rights of individuals belonging to specific categories, and that it remains a feature on this agenda today.

In Chapter 2, Simone Cusack analyses the engagement of the UN Treaty Bodies and Special Mechanisms with the concept of stereotyping. She finds that, as a result of the work of the CEDAW Committee, references to gender stereotyping are most common. In her analysis of the CEDAW Committee's work, Cusack finds increasing nuance in the language that is used to engage with gender stereotyping, as well as increasing depth in the analysis of the impact of stereotyping. In terms of commonality of referencing, disability stereotyping comes second. Nevertheless, Cusack finds neither the CEDAW Committee nor the CRPD Committee systematically and consistently integrate an antistereotyping approach in their work, and that a lot of work remains to be done to further develop such an approach. References to other types of stereotyping (eg racial stereotyping) occasionally occur in the UN mechanisms, yet Cusack finds that these have been mostly weak and ad hoc. Missed opportunities abound to strengthen the analysis of human rights violations by pointing out the harmful work of stereotyping. The chapter adopts a constructive approach, putting the finger on the main weaknesses of current approaches, and suggesting strategies to overcome these. Cusack emphasises in particular the need to accurately identify stereotypes. This implies distinguishing them from related concepts, such as myths or prejudice, as well as distinguishing between the actual stereotypes and the assumptions that underpin them. In Cusack's opinion, correctly naming the 
stereotype at work is crucial to avoid 'concealment of the specific belief that needs to be modified or transformed and the practice that needs to be eliminated'. In addition, she points at the importance of elaborating state obligations related to stereotyping.

Chapter 3, by Lourdes Peroni and Alexandra Timmer, combines a focus on a single forum (the European Court of Human Rights) with a thematic focus on domestic violence cases. Thus, the authors' starting point is not the intrinsic harm of stereotyping as such, but rather its pernicious role as a facilitator of other human rights violations. Concretely, they discuss gender stereotyping as 'one of the factors that structurally contribute to domestic violence and ineffective state responses'. The authors find the confirmation of this structurallink in international human rights law, in particular in the work of the CEDAW Committee and in the Istanbul Convention. This implies that gender-based violence cannot be tackled without addressing the gender stereotypes in which it is rooted. In that context, it is vital that those combatting gender-based violence avoid reiterating narratives of vulnerability that may reconfirm harmful gender stereotypes. In line with Cusack's argument (cf Chapter 2), the authors put a lot of emphasis on naming stereotypes. In a careful analysis of the European Court's domestic violence case law, they identify at least five distinct gender stereotypes, and explain how they work. Like Cusack, they also adopt a constructive approach that shows the way forward. In addition to naming stereotypes, they argue that the Court should contest them. They argue that the Court should stipulate positive state obligations to address the stereotypes that are at the root of domestic violence. In addition, they argue that evidence that state agents gender stereotyped the victim and/or the perpetrator of domestic violence, should lead to a finding of discrimination.

If we wanted to stereotype regional human rights courts, the ECtHR would be typecast as very prudent, always looking over its shoulder for the political reaction its judgments might cause, preferring incremental over radical approaches, and electing to be silent about potentially controversial issues that it need not strictly address. In contrast, the IACtHR might be presented as the daughter of many revolutions, preferring big steps over small ones, and not shying away from strong language or highly innovative interpretations.

The kernel of truth in this deliberately overstated comparison explains the change in approach between Chapters 3 and 4. In Chapter 4, Verónica Undurraga analyses the Inter-American Court's approach to gender stereotyping. While the European Court needs some encouragement to engage in stereotyping analysis (cf Chapter 3), its American counterpart might instead need to exercise some caution, the author explains. Undurraga presents a detailed analysis of two flagship cases, the Cotton Field case about gender-based violence, and the Atala Riffo case about loss of child custody on account of sexual orientation. In both cases, the Court explicitly and in some detail discusses gender stereotypes as part of the structural causes of the human rights violations that were at stake. The author explains how they reveal the Inter-American Court's substantive and 
transformative vision of (gender) equality. This extends to the Court's decisions on reparation measures, a field in which the European Court does not even tread. The author applauds the Court's educational and expressive role, yet she also issues a number of warnings. Firstly, Undurraga points at the numerous legal hurdles that lie ahead if the Court wants to continue on this road. Challenging the Court to further develop its doctrine on stereotyping, she points out the need to target not stereotypes as such but rather to distinguish a subset of 'harmful' stereotypes, which requires the development of criteria on the basis of which this distinction can be operated. In addition, the author sees a need for the Court to more clearly define the aim of its interventions in this field and to adapt its language and reparatory measures accordingly. One reason why such strong legal anchoring of the Court's anti-stereotyping doctrine might be needed is presented in the chapter's last section, which predicts a conservative backlash against the Court on account of what is perceived as its radical gender ideology.

To the extent that international human rights law has engaged with stereotyping, this has mostly been in the form of gender stereotyping. And as these chapters show, many interesting lessons can be drawn from this experience that affect stereotyping on other grounds. This book focuses on other types of stereotyping, and it does so in detail in Chapter 5 about (mental) disability stereotyping and Chapter 6 on racial stereotyping.

In Chapter 5, Michael Perlin proposes the term 'sanism' as an analogy to racism and sexism for discussions about (legal) attitudes to people with mental disabilities. Sanism is based on stereotypes and stigma and, according to the author, pervades every area of mental disability law. Perlin does not recognise a need to distinguish harmful from other stereotypes vis-à-vis persons with disabilities, as in his opinion 'there is no evidence of any "positive" stereotyping with regard to this population'. Using examples that are mainly from domestic US law, Perlin identifies many of the stereotypes that are at work in this context, analyses how they function, and the harm they inflict on individuals' dignity. Perlin uncovers sanist stereotypes in the legal process, as well as in legislative debate. He underscores the importance of law and court rulings in this field with reference to the scholarship on 'therapeutic jurisprudence'. Law has a therapeutic potential, yet this potential is too often wasted. The author argues that 'sanism has never been taken as seriously as racism, sexism or homophobia'. Yet he sees some glimmers of hope. One of these is based in a number of US and international court decisions that have acknowledged the negative impact of sanist stereotyping. The other is the CRPD: 'if taken seriously, the CRPD can potentially be the best weapon - ever - in the fight against sanist stereotypes that stigmatize persons with disabilities'.

In Chapter 6 as well, the evidence of an anti-stereotyping approach is limited. In his analysis of racial stereotyping as a human rights issue, Mathias Möschel identifies a mostly untapped potential for integrating this approach in international human rights norms and cases on racial discrimination. His exploration includes 
both the identification of racial stereotyping as a human rights violation in its own right, and its contribution to other human rights violations, in particular those involving violence - namely genocide, and racially motivated violence by state as well as private actors. In the case law of the International Criminal Tribunals for Rwanda and for the former Yugoslavia, as well as in the case law of the European Court of Human Rights about violence against Roma, Möschel finds a few examples that show some recognition that racist stereotypes leading to violence constitute a human rights problem. Yet these examples remain exceptional, and they fail to show an in-depth understanding of the impact of such stereotypes. Outside the context of violence, Möschel finds isolated examples of good practice: the European Court's case law on racist bias by domestic courts, and the UN Human Rights Committee's decision on racial profiling as discrimination. Yet his overall finding is that 'the recognition of racial stereotypes by binding human rights law is haphazard at best, quite limited, and rarely explicit'. That is why he turns to non-binding law, exploring the role of stereotypes in the work of the UN CERD Committee and of the European Commission against Racism and Intolerance (ECRI). He finds that in the work of the CERD Committee, racial stereotyping is acknowledged to some extent, in particular in its observations on state reports under Article 7 CERD, concerning the obligation of 'combating prejudices which lead to racial discrimination', and in its case law interpreting Article 4 CERD, on the obligation to tackle racist hate speech. Yet the CERD Committee does not use the term 'stereotypes' as such. This is different for the ECRI, which has explicitly addressed racial stereotyping in some of its recommendations and country reports. In the opinion of Möschel, 'possibly the ECRI is the most advanced institution in openly acknowledging and addressing the issue of racial stereotypes under human rights law'. The author thinks that more attention is needed for the role of racial stereotypes in human rights fora. He suggests that the CERD Committee adopt a general recommendation about Article 7 CERD that is similar to General Recommendation No 25 of the CEDAW Committee on Article 5 CEDAW. Moreover, seeing parallels with gender stereotypes also at a more fundamental level, Möschel suggests using the concept of indirect discrimination to show the negative impact of racist stereotypes.

The volume concludes with two fascinating case studies.

In Chapter 7, Rikki Holtmaat presents the case of the SGP, an orthodox Calvinist political party in the Netherlands that up to 2013 refused to present female candidates for elections on its list. This situation gave rise to no less than fourteen legal procedures, in which the SGP was ultimately defeated. Nevertheless, Holtmaat argues that this case illustrates that equality law may not be the most suitable tool to combat gender stereotypes. Among the fourteen legal procedures on the topic, only one addressed the gender stereotypes at the basis of the party's ideology. Holtmaat finds that 'legally construing the SGP's exclusion of women from political participation as an issue of unequal treatment of women, to a large extent stood in the way of effectively redressing the gender stereotypes at stake 
in these procedures'. The author argues that the anti-discrimination framework led to a distortive representation of the stakes for women. In her opinion, the heart of the matter was not a disadvantage as compared to men, but rather the situation in which women did not have a say in defining what their community considers an appropriate role for them, and the fact that the Dutch State, through its subsidies for this party, facilitated the dissemination of gender stereotypes. Holtmaat objects strongly to the framing of the case in terms of conflicting fundamental rights. This came down to a defence of a discriminatory rule by an appeal on traditional patriarchal values, which cannot be accepted in light of the State's commitment under Article 5 CEDAW to eradicate patriarchal gender stereotypes. She concludes that gender justice requires different, more sophisticated legal metaphors than those of 'balancing' and 'conflicting rights'.

Finally, Chapter 8, by Rebecca Cook and Cornelia Weiss, looks at gender stereotyping in the military. The military is a highly relevant setting for the study of gender stereotyping, as it is directly related with the exercise of power and as it has traditionally been associated with core traits of 'masculinity': 'where women take on warrior and leadership roles that have traditionally belonged to men, hostile stereotyping emerges to keep women out of, invisible in, or relegated to support roles in, the military rather than embraced by it'. The authors present a rich pallette of domestic and regional cases that have analysed potential gendered violations of the fundamental rights of women and men in the military. Their cases illustrate that gender stereotyping may harm men as well as women, and that harmful stereotypes about women may be at the heart a case that is ostensibly about discrimination against men (eg the ECtHR case of Konstantin Markin $v$ Russia about parental leave). The authors distinguish three types of cases. In the first type, exclusion cases, unsubstantiated generalisations are at work; yet courts have intervened without explicitly naming the stereotypes. In the other types of cases, concerning unequal treatment and sexual assault, courts have named the stereotypes (which were under-inclusive generalisations in the first category and false stereotypes in the second), and have discussed the harm they inflict at individual and group level. The authors hypothesise that the difference can be explained by the degree of awareness-raising that had already been done about gender prejudices in the military. 



\title{
BUILDING MOMENTUM TOWARDS CHANGE
}

\author{
How the UN's Response \\ to Stereotyping is Evolving
}

\author{
Simone CUSACK ${ }^{\star}$
}

\section{INTRODUCTION}

The number of human rights issues commanding and deserving attention throughout the world is undeniably shocking. ${ }^{1}$ A broad range of factors affect whether or not any of those issues receive attention, as well as any action that is taken to address them. If and how the United Nations (UN) responds to particular human rights issues is one factor that is often critical in generating and sustaining interest in an issue. ${ }^{2}$ It can also be important in the identification of solutions that will bring about real change in respect of that issue - ones that are capable of ensuring the recognition, exercise and enjoyment of human rights and fundamental freedoms.

This chapter examines the UN's evolving response to one particular human rights issue, namely stereotyping. ${ }^{3}$ It explains that interest in gender stereotyping

* The author would like to thank Prof Eva Brems and Dr Alexandra Timmer for their leadership in organising the 'Stereotyping as a Human Rights Issue' conference, held in December 2013. Special thanks are also due to Professor Rebecca J Cook for her constant leadership, contributions, collaborations and insightful comments on the issue of stereotyping and earlier drafts of this chapter, as well as the Women's Human Rights and Gender Section of the Office of the High Commissioner for Human Rights, the anonymous reviewers and the conference participants for their thoughtful comments on earlier drafts. Any errors are the responsibility of the author alone. This chapter is written in the author's personal capacity. With few exceptions, the information, laws and jurisprudence referred to in this chapter were current as at March 2015.

$1 \quad$ See eg Human Rights Watch, World Report: Events of 2013 (Human Rights Watch 2014).

2 See eg Free \& Equal, the United Nations campaign for lesbian, gay, bisexual, and transgender equality <https://www.unfe.org/en> accessed 23 March 2015.

The term 'stereotyping' is used in this chapter to refer to the 'process of ascribing to an individual specific attributes, characteristics, or roles by reason only of her or his membership 
has increased significantly within the UN over the past five or so years and that interest in disability stereotyping has also grown during this time, albeit to a far lesser extent. It argues that the heightened interest in, and examination of, gender and disability stereotyping has contributed to improved UN responses to those types of stereotyping, which has, in turn, aided the identification of solutions that seek to bring about change for people experiencing those types of stereotyping. The Committee on the Elimination of Discrimination against Women (CEDAW Committee or Committee), it is claimed, has been a leader in this regard.

While there has been a noticeable evolution in responses to gender and (to a lesser extent) disability stereotyping over the past half-decade, the chapter contends that UN human rights mechanisms have given comparatively little attention to other types of stereotyping and that their responses to this issue have been ad hoc and weak as a result. A number of reasons are offered for the differing responses: the absence of express treaty obligations dealing with those other types of stereotyping; the limited awareness amongst many UN mechanisms of relevant treaty obligations; ${ }^{4}$ and the failure of many UN mechanisms to identify, and seize opportunities to hold States Parties accountable for, relevant stereotyping violations.

Notwithstanding the changing UN responses to gender and disability stereotyping over the past half-decade, greater efforts are needed to strengthen UN responses to other types of stereotyping. In this, it is suggested, there are crucial lessons to be learned from the UN's evolving responses to gender stereotyping. At the same time, it is claimed that there is still considerable room to improve UN responses to gender and disability stereotyping, including by expanding the range of UN mechanisms that engage with those types of stereotyping and further strengthening the analysis of their impact on human rights. This chapter suggests that the CEDAW Committee's work on gender stereotyping will provide a solid foundation upon which to continue strengthening UN responses to stereotyping. However, it also suggests that reliance on the Committee's work will not alone be sufficient to address all types of stereotyping; it is incumbent on all UN human rights mechanisms, supported by the Office of the High Commissioner for Human Rights (OHCHR or Office) and human rights advocates, to address stereotyping as part of their respective mandates.

The chapter begins in section 2 by critically analysing some of the key developments in UN responses to stereotyping over the past half-decade. Building on research the author completed for the OHCHR, ${ }^{5}$ it examines: the growing

in a particular group'. See Rebecca J Cook and Simone Cusack, Gender Stereotyping: Transnational Legal Perspectives (University of Pennsylvania Press 2010) 12.

See section 2.1 .3 below.

Simone Cusack, Gender Stereotyping as a Human Rights Violation: Research Report, Commissioned by the UN Office of the High Commissioner for Human Rights (2013) 20-41, <www.ohchr.org/Documents/Issues/Women/WRGS/2013-Gender-Stereotyping-as-HRViolation.docx > accessed 28 March 2015. 
visibility of gender and disability stereotyping within the UN; the increasing sophistication of UN analyses of those types of stereotyping; and, the recent leadership the OHCHR has shown on the issue. Section 3 then highlights some of the main weaknesses in current responses to stereotyping, namely the regular failure of many UN mechanisms to identify stereotypes accurately, the lack of guidance provided to date on relevant human rights obligations, and the limited awareness of good practice examples of challenging stereotyping. Section 3 also identifies strategies for strengthening UN responses to this issue, with a view to continuing to build momentum towards the identification and implementation of solutions that will bring about real change. It suggests that further work is needed to build the capacity of UN mechanisms to understand, identify and challenge stereotypes. It also suggests that UN mechanisms should take additional steps to elaborate state obligations related to stereotyping. And lastly it calls on UN mechanisms to identify and highlight practices that are bringing about positive change in relation to stereotyping. The chapter concludes with a brief reflection on how UN mechanisms can translate the current momentum around the issue of gender stereotyping into real and meaningful change moving forward.

\section{KEY DEVELOPMENTS IN UN RESPONSES TO STEREOTYPING}

State obligations to address stereotyping long have been a feature of international human rights law. The Convention on the Elimination of All Forms of Discrimination against Women (CEDAW), ${ }^{6}$ adopted in 1979, was the first international human rights treaty to introduce express obligations on stereotyping. In general terms, it requires States Parties to modify or transform harmful gender stereotypes and eliminate wrongful gender stereotyping. ${ }^{7}$ Further obligations were introduced in 2006, with the adoption of the Convention on the Rights of Persons with Disabilities (CRPD), which requires States Parties to take measures to combat stereotypes of people with disabilities. ${ }^{8}$ Two further treaties, adopted in 1989 and 1965 respectively, are also noteworthy. The Convention on the Rights of the Child (CRC) appears to reject the stereotype that all children are immature and therefore incapable of making informed decisions or expressing informed views, by requiring their evolving capacities to be taken into account and their views to be

6 Convention on the Elimination of All Forms of Discrimination against Women (adopted 18 December 1979, entered into force 3 September 1981) 1249 UNTS 13 (CEDAW). See generally Marsha A Freeman, Christine Chinkin and Beate Rudolf (eds), The UN Convention on the Elimination of All Forms of Discrimination against Women: A Commentary (OUP 2012). CEDAW, preambular para 14, Arts 2(f), 5, 10(c). See also R.K.B. v Turkey, Communication No 28/2010, UN Doc CEDAW/C/51/D/28/2010 (2012) para 8.8 .

8 Convention on the Rights of Persons with Disabilities (adopted 13 December 2006, entered into force 3 May 2008) 2515 UNTS 3 (CRPD) Arts 4(1)(b), 8(1)(b). 
given due weight. ${ }^{9}$ The International Convention on the Elimination of All Forms of Racial Discrimination (ICERD) requires States Parties to combat prejudice (a related and sometimes overlapping problem), resulting in discrimination. ${ }^{10}$ Additionally, many treaty bodies, including the Human Rights Committee $(\mathrm{HRC})^{11}$ and the Committee on Economic, Social and Cultural Rights, ${ }^{12}$ have recognised implied obligations to address stereotyping.

Considering these international obligations, it is important to take stock of how UN mechanisms are addressing stereotyping and whether those responses are helping to identify robust solutions to this important human rights issue. A review of the jurisprudence of those mechanisms shows that there have been several important developments concerning stereotyping, particularly over the past five or so years. Gender stereotyping, and disability stereotyping more recently and to a lesser extent, have been at the centre of most of those developments, with only limited attention given by UN mechanisms to other types of stereotyping. Since space does not permit all of the developments to be highlighted here, section 2 canvasses three that stand out. They are: the increased visibility of stereotyping within the UN; the growing sophistication in how UN mechanisms analyse stereotyping and its resultant harms; and the growing leadership role played by the OHCHR in addressing this issue.

\subsection{THERE IS GREATER VISIBILITY OF STEREOTYPING WITHIN THE UN}

\subsubsection{Gender Stereotyping}

Gender stereotyping, more than any other type of stereotyping, has been visible within the UN human rights system for a number of years. The visibility of this type of stereotyping is likely due to the early adoption of state obligations related to stereotyping in CEDAW, and the CEDAW Committee's ongoing scrutiny of this issue. After all, it was back in 1987 that the CEDAW Committee adopted its General Recommendation No 3 urging States Parties 'to adopt education and public information programmes, which will help eliminate prejudices and current

$9 \quad$ Convention on the Rights of the Child (adopted 20 November 1989, entered into force 2 September 1990) 1577 UNTS 3 (CRC) Arts 5, 12(1), 14(2).

10 International Convention on the Elimination of All Forms of Racial Discrimination (adopted 21 December 1965, entered into force 4 January 1969) 660 UNTS 195 (ICERD) Art 7.

11 See eg Human Rights Committee, General Comment No 28: Article 3 (The Equal Rights of Men and Women), UN Doc HRI/GEN/1/Rev 9 (Vol I) (2000) para 5; Human Rights Committee, Concluding Observations: Cameroon, UN Doc CCPR/C/CMR/CO/4 (2010) para 8.

12 See eg Committee on Economic, Social and Cultural Rights, General Comment No 16: The Equal Right of Men and Women to the Enjoyment of All Economic, Social and Cultural Rights, UN Doc E/C.12/2005/4 (2005) paras 11, 14, 19, 22; Committee on Economic, Social and Cultural Rights, General Comment No 20: Non-Discrimination in Economic, Social and Cultural Rights, UN Doc E/C.12/GC/20 (2009) paras 20, 35. 
practices that hinder the full operation of the principle of the social equality of women'. ${ }^{13}$

The Committee's early jurisprudence focused mainly on the impact of stereotyping in the education and employment sectors as well as in marriage and family relations. It was common, for example, for the CEDAW Committee to express concern about stereotyping that confines women to, or excludes them from, certain roles in political and public life, or that results in the devaluing of work traditionally performed by women. ${ }^{14}$ The Committee also emphasised early on the importance of education initiatives, and working with the media, as a way of challenging stereotyping. For instance, it would often urge States Parties to implement programmes and campaigns to change stereotypical attitudes, and to work with the media to project a positive image of women and change views about the roles and responsibilities of women and men within the family and in society. ${ }^{15}$ However, the Committee's early recommendations rarely extended beyond such initiatives and provided only limited guidance on how States Parties might fulfil their CEDAW obligations on stereotyping.

The CEDAW Committee has expanded its focus more recently, examining the impact of stereotyping in diverse areas of life and urging States Parties to implement a wider range of measures to challenge stereotyping. These measures have included adopting a comprehensive strategy on stereotyping, ${ }^{16}$ implementing temporary special measures to accelerate the transformation of harmful stereotypes, ${ }^{17}$ and ensuring systems for the identification of asylum seekers and refugees are not based on gender stereotypes. ${ }^{18}$ At the same time as the Committee has broadened its focus, it has stressed the significance of

13 CEDAW Committee, General Recommendation No 3: Education and Public Information Programmes, UN Doc A/42/38 at 78 (1987). For an overview of the CEDAW Committee's work on Article 5 of CEDAW, the treaty's main provision on stereotyping, see Rikki Holtmaat, 'Article 5' in Marsha A Freeman, Christine Chinkin and Beate Rudolf (eds), The UN Convention on the Elimination of All Forms of Discrimination against Women: A Commentary (OUP 2012) 141.

14 See eg CEDAW Committee, General Recommendation No 21: Equality in Marriage and Family Relations, UN Doc. A/49/38 at 1 (1994) paras 11, 12; CEDAW Committee, General Recommendation No 23: Political and Public Life, UN Doc. A/52/38/Rev1 at 61 (1997) paras 12, 20(c), 20(d), 27, 28, 44 .

15 See eg Report of the Committee on the Elimination of Discrimination against Women: TwentyEighth Session; Twenty-Ninth Session, UN GAOR, 58 ${ }^{\text {th }}$ sess, Supp No 38, UN Doc A/58/38 (2003) (Part I) paras 69, 115, 210, 309; (Part II) paras 109, 167.

16 See eg CEDAW Committee, Concluding Observations: Russia, UN Doc CEDAW/C/USR/CO/7 (2010) para 21; CEDAW Committee, Concluding Observations: Albania, UN Doc CEDAW/C/ ALB/CO/3 (2010) para 25; CEDAW Committee, Concluding Observations: United Arab Emirates, UN Doc CEDAW/C/ARE/CO/1 (2010) para 25.

17 CEDAW Committee, General Recommendation No 25, on Article 4, Paragraph 1, of the Convention on the Elimination of All Forms of Discrimination against Women, on Temporary Special Measures, UN Doc A/59/38 (2004) para 38.

18 CEDAW Committee, General Recommendation No 32 on the Gender-Related Dimensions of Refugee Status, Asylum, Nationality and Statelessness of Women, UN Doc CEDAW/C/GC/32 (2014) para 44. 
state obligations on stereotyping for the realisation of the rights guaranteed by CEDAW. Notably, in its General Recommendation No 25, it characterised the obligation to 'address prevailing gender relations and the persistence of genderbased stereotypes' ${ }^{\prime 19}$ as one of three categories of obligations central to the achievement of substantive equality. The Committee reinforced the importance of this obligation in R.K.B. $v$ Turkey, an employment discrimination case, when it explained that 'full implementation of the Convention requires States parties to modify and transform gender stereotypes and eliminate wrongful gender stereotyping, ${ }^{20}$

Although stereotyping has long been on the CEDAW Committee's radar, the entry into force of the Optional Protocol to the Convention on the Elimination of All Forms of Discrimination against Women ${ }^{21}$ (Optional Protocol) gave even greater visibility to stereotyping within the UN and provided the Committee further opportunities to strengthen its response to the issue. The reason the Optional Protocol was such a critical turning point is that, for the first time, the Committee could examine the impact of stereotyping on the rights of individual women. For instance, in L.C. $v$ Peru, a reproductive rights case, the Committee considered how the stereotype that women should be mothers - and its underpinning assumption that women should prioritise childbearing and childrearing over their own lives and health and over all other roles they might perform or choose - influenced the decision of doctors to delay spinal surgery, and their refusal to perform a therapeutic abortion, on a minor who was raped and subsequently attempted suicide. $^{22}$

After overcoming tentative beginnings, when it missed crucial opportunities to address stereotyping, ${ }^{23}$ the Committee now routinely uses its views in individual communications to examine and shed important light on the harms of, and hold States Parties accountable for, stereotyping. Its 2010 decision in Karen Tayag Vertido $v$ the Philippines, ${ }^{24}$ a sexual violence case, was a watershed in this regard. Arguably the leading UN case on stereotyping at the time of writing, the

19 CEDAW Committee, General Recommendation No 25 (n 17) para 7. See also R.K.B. (n 7) para 8.8.

20 R.K.B., ibid.

21 Optional Protocol to the Convention on the Elimination of All Forms of Discrimination against Women (adopted 10 December 1999, entered into force 22 December 2000) 2131 UNTS 83 (OPCEDAW). For an overview of the CEDAW Committee's jurisprudence under the Optional Protocol, see Simone Cusack and Lisa Pusey, 'CEDAW and the Rights to Non-Discrimination and Equality' (2013) 14 MJIL 54.

22 L.C. v Peru, Communication No 22/2009, UN Doc CEDAW/C/50/D/22/2009 (2011) para 8.15. For an analysis of this case, see Charles N Ngwena, 'A Commentary on LC v Peru: The CEDAW Committee's First Decision on Abortion' (2013) 57(2) JAfrL 310.

23 See Cook and Cusack (n 3) 156-160, 167-172; Simone Cusack, 'The CEDAW as a Legal Framework for Transnational Discourses on Gender Stereotyping' in Anne Hellum and Henriette Sinding Aasen (eds), Women's Human Rights: CEDAW in International, Regional and National Law (CUP 2013) 124, 139.

24 Karen Tayag Vertido $v$ the Philippines, Communication No 18/2008, UN Doc CEDAW/ C/46/D/18/2008 (2010). For an analysis of this case, see Simone Cusack and Alexandra SH 
CEDAW Committee held the State Party accountable for a trial judge's decision to acquit an accused of rape based on gender stereotypes, rather than on law or fact. ${ }^{25}$ In doing so, it affirmed that judicial stereotyping violates the rights to nondiscrimination and a fair trial, and explained that judges must not create inflexible standards of how women should behave when confronted with a situation of rape, based on gender stereotypes. ${ }^{26}$ It also called on the State Party to ensure that legal procedures in rape cases are 'impartial and fair, and not affected by prejudices or stereotypical gender notions'. ${ }^{27}$

Although the Committee's views in individual communications have given greater visibility to the impact of stereotyping in a range of areas, it has been its views on stereotyping in communications about gender-based violence that have been most prominent to date. Through these views, which build on its General Recommendation No 19 on violence against women, ${ }^{28}$ the Committee has affirmed repeatedly that stereotyping is a root cause of gender violence, and stressed the need to challenge stereotyping as a way of preventing such violence. ${ }^{29}$ It has also affirmed the importance of States Parties taking steps to ensure: investigations into allegations of violence are conducted impartially and free of stereotypes; ${ }^{30}$ and stereotyping does not compromise access to justice for victims/survivors. ${ }^{31}$ Additionally, in Ángela González Carreño v Spain, a domestic violence case, the Committee emphasised the need to ensure that stereotyping does not result in the rights of abusers being prioritised over those of victims/survivors in child custody and visitation decisions. ${ }^{32}$ In upholding the claim, the Committee explained that the decision to grant F.R.C. unsupervised visits with his daughter was based on stereotypes that privileged his (male) interests and minimised his abusive

Timmer, 'Gender Stereotyping in Rape Cases: The CEDAW Committee's Decision in Vertido $v$ The Philippines' (2011) 11 HRLR 329.

25 Vertido, ibid paras 8.5-8.6, 8.9.

26 Ibid para 8.4.

$27 \quad$ Ibid para 8.9(b).

28 CEDAW Committee, General Recommendation No 19: Violence against Women, UN Doc A/47/38 at 1 (1993) paras 11-12, 21, 23, 24(e), 24(f), 24(t)(ii). For an overview of the CEDAW Committee's work on gender-based violence against women, see Christine Chinkin, 'Violence Against Women' in Marsha A Freeman, Christine Chinkin and Beate Rudolf (eds), The UN Convention on the Elimination of All Forms of Discrimination against Women: A Commentary (OUP 2012) 443.

29 Isatou Jallow v Bulgaria, Communication No 32/2011, UN Doc CEDAW/C/52/D/32/2011 (2012) para 8.6; V.K. v Bulgaria, Communication No 20/2008, UN Doc CEDAW/C/49/D/20/2008 (2011) para 9.11; Fatma Yildirim (deceased) v Austria, Communication No 6/2005, UN Doc CEDAW/C/39/D/6/2005 (2007) para 12.2; Şahide Goekce (deceased) v Austria, Communication No 5/2005, UN Doc CEDAW/C/39/D/5/2005 (2007) para 12; A.T. v Hungary, Communication No 2/2003, UN Doc CEDAW/C/32/D/2/2003 (2005) para 9.4.

30 Isatou Jallow $v$ Bulgaria, ibid para 8.6.

31 Ángela González Carreño v Spain, Communication No 47/2012, UN Doc CEDAW/ C/58/D/47/2012 (2014) para 9.4; V.K. (n 29) para 9.11; Vertido (n 24) paras 8.4, 8.9(b); R.P.B. v the Philippines, Communication No 34/2011, UN Doc CEDAW/C/57/D/34/2011 (2014) para 8.8.

32 González Carreño, ibid paras 9.4, 9.7. 
behaviour. ${ }^{33}$ It also affirmed that child custody and visitation decisions should be based on the best interests of the child, not on stereotypes, with domestic violence being a relevant consideration. ${ }^{34}$

While the CEDAW Committee's evolving response to stereotyping is to be celebrated, the strength of the response has been curbed by its failure at times to identify instances of stereotyping ${ }^{35}$ and identify and name stereotypes accurately. ${ }^{36}$ Even when stereotyping and stereotypes have been identified, there has sometimes been a disconnect between that identification and the subsequent recommendations made by the Committee. In other words, despite its initial work in diagnosing the problem, the Committee has on occasion failed to include in its jurisprudence recommendations to address stereotyping or, if it has made recommendations, they have been general in nature and given only limited guidance to States Parties. For example, despite concluding in A.T. v Hungary that stereotyping had played a central role in the domestic violence experienced by A.T., ${ }^{37}$ the Committee did not make any specific recommendations in respect of how the State Party might go about the difficult task of modifying or transforming the operative stereotypes or eliminating the practice of wrongful gender stereotyping.

Despite the limitations of some of its responses, the CEDAW Committee has laid a solid foundation for the expanding discourse on gender stereotyping within the UN and, importantly, it continues to strengthen its response to this issue. Moreover, the attention it has given to gender stereotyping has helped to propel the issue onto the international human rights stage, encouraged other mechanisms to give the issue serious attention and shown them how they might begin to engage with this and other types of stereotyping. The growing number of UN human rights mechanisms that address gender stereotyping, referencing the work of the CEDAW Committee as they do, is clear evidence of the impact its

\section{Ibid.}

Ibid para 9.4.

See eg Cristina Muñoz-Vargas y Sainz de Vicuña v Spain, Communication No 7/2005, UN Doc CEDAW/C/39/D/7/2005 (2007). One Committee member, in a dissenting opinion, condemned a Spanish law that entrenched male primacy in the order of succession because it perpetuated discrimination and institutionalised stereotypes: at paras 13.1-13.13. However, the other members either did not identify the gender stereotypes codified in the law or opted not to address them in this case. Had they done so, they might, as the dissenting Committee member did, have determined to declare the communication admissible.

${ }_{36}$ See eg L.C. (n 22). The CEDAW Committee found in this case that the State Party had violated Article 5 of CEDAW when its doctors treated a pregnant minor on the basis of the stereotype 'that protection of the foetus should prevail over the health of the mother', para 8.15. It is suggested respectfully that the stereotype at play in this case is that 'women should be mothers' and the assumption underpinning that stereotype is that women should prioritise childbearing and childrearing over their own lives and health and over all other roles they might perform or choose. That is to say, the Committee identified the assumption underpinning the stereotype and not the stereotype itself. 
work is having in raising the visibility of, and improving responses to, this issue within the UN.

Consider, for example, the 2013 report of the UN Special Rapporteur on extreme poverty and human rights, which analysed the relationship between unpaid care work, inequality and women's human rights. The report provided key insights into how gender stereotypes (eg men as breadwinners, women as carers/nurturers) influence the distribution of unpaid care work between women and men and, in many instances, discriminate and condemn women to poverty. ${ }^{38}$ Referencing CEDAW and the jurisprudence of the CEDAW Committee, the Special Rapporteur stressed the importance of transforming stereotypes that lead to the gendered and unequal division of unpaid care responsibilities. ${ }^{39}$ This, she elaborated, requires States Parties to 'recognize and value the importance of unpaid care, but without reinforcing care work as women's sole responsibility or supporting particular models of the family to the exclusion of others' ${ }^{40}$ In addition to not enforcing or perpetuating gender stereotypes, ${ }^{41}$ the Special Rapporteur underscored the importance of States Parties challenging those stereotypes, ${ }^{42}$ including by promoting 'the concept of shared family responsibility for unpaid care work in the home'. ${ }^{43}$

\subsubsection{Disability Stereotyping}

Disability stereotyping ${ }^{44}$ has emerged during the past half-decade as a growing area of interest within the UN, likely due to the entry into force in 2008 of the CRPD and the work of advocates around this type of stereotyping. ${ }^{45}$ The CRPD is only the second international human rights treaty to introduce express obligations related to stereotyping (although such obligations are contained in a number of regional treaties). ${ }^{46}$ It is also the first treaty to impose an express

$38 \quad$ UNHRC, 'Report by Special Rapporteur on Extreme Poverty and Human Rights Magdalena Sepúlveda Carmona' (2013) UN Doc A/68/293, paras 8, 13, 21, 29. See also Australian Human Rights Commission, Investing in Care: Recognising and Valuing those who Care; Volume 1: Research Report (Australian Human Rights Commission 2013); Australian Human Rights Commission, Accumulating Poverty? Women's Experiences of Inequality over the Lifecycle; An Issues Paper Examining the Gender Gap in Retirement Savings (Australian Human Rights Commission 2009).

39 Sepúlveda Carmona, ibid paras 13, 21, 61, 70.

$40 \quad$ Ibid para 70 .

$41 \quad$ Ibid para 74.

$42 \quad$ Ibid paras 86,94 .

$43 \quad$ Ibid para 94.

44 For a more detailed analysis of disability stereotyping, see chapter 5 in this volume.

45 See eg Stephanie Ortoleva, 'Women with Disabilities: The Forgotten Peace Builders' (2010) 33 LoyLA Il CLR 83, 90-92, 114, 139; Stephanie Ortoleva and Hope Lewis, 'Forgotten Sisters: A Report on Violence against Women with Disabilities: An Overview of its Nature, Scope, Causes and Consequences' School of Law Faculty Publications, Paper 184 (2012) <http://hdl. handle.net/2047/d20002563> accessed 28 March 2015.

46 See eg see Protocol to the African Charter on Human and Peoples' Rights on the Rights of Women in Africa (entered into force 25 November 2005) OAU Doc CAB/LEG/66.6 Arts 2(2), 
obligation to address compounded stereotypes, requiring States Parties to 'adopt immediate, effective and appropriate measures to combat stereotypes, prejudices and harmful practices relating to persons with disabilities, including those based on sex and age, in all areas of life'. ${ }^{47}$ This obligation is particularly significant as it acknowledges that experiences of discrimination and other rights violations may differ when stereotyping is based on multiple attributes.

Through a small but growing number of Concluding Observations, the Committee on the Rights of Persons with Disabilities (CRPD Committee) is beginning to emphasise the importance of adopting education and training measures to combat stereotypes and prejudices, and to promote the dignity, capabilities and contributions of people with disabilities. ${ }^{48}$ It has, for instance, urged States Parties to introduce awareness-raising initiatives to: challenge the stereotypical view of people with disabilities as vulnerable and, therefore, in need of protection ${ }^{49}$ or as the object of charity. ${ }^{50}$ The CRPD Committee has also encouraged States Parties to develop and implement policies and programmes to combat stereotypes of people with disabilities. ${ }^{51}$ The inclusion of recommendations related to policy initiatives is important because it demonstrates an awareness of the broad-ranging and holistic measures needed to challenge stereotyping and, in this, reflects lessons learned from the CEDAW Committee's evolving jurisprudence on stereotyping.

While the CRPD Committee is still developing its body of jurisprudence (and will presumably offer more substantive contributions on disability stereotyping moving forward), it has nevertheless overlooked key opportunities to address this issue in its work to date. For instance, the CRPD Committee failed to consider disability stereotyping in its General Comment No $1^{52}$ on equal recognition before the law, despite acknowledgment that disability stereotypes have undermined equal recognition for people with intellectual disabilities..$^{53}$ Like with the CEDAW

4(2)(d), 12(1)(b); Inter-American Convention on the Prevention, Punishment and Eradication of Violence against Women (entered into force 5 March 1995) OAS/Ser.L/V/1.4 rev Arts 6(b), 8(b).

$47 \quad$ CRPD, Art 8(1)(b).

48 See eg CRPD Committee, Concluding Observations: Tunisia, UN Doc CRPD/C/TUN/CO/1 (2011) para 15(a); CRPD Committee, Concluding Observations: Peru, UN Doc CRPD/C/ PER/CO/1 (2012) para 19; CRPD Committee, Concluding Observations: El Salvador, UN Doc CRPD/C/SLV/CO/1 (2013) paras 21-22; CRPD Committee, Concluding Observations: Denmark, UN Doc CRPD/C/DNK/CO/1 (2014) paras 22-23.

49 See eg CRPD Committee, Concluding Observations: Austria, UN Doc CRPD/C/AUT/CO/1 (2013) para 22; CRPD Committee, Concluding Observations: Azerbaijan, UN Doc CRPD/C/ $\mathrm{AZE} / \mathrm{CO} / 1$ (2014) para 21.

50 CRPD Committee, Concluding Observations: Mexico, UN Doc CRPD/C/MEX/CO/1 (2014) paras $17-18$.

51 See eg CRPD Committee, Concluding Observations: Peru, UN Doc CRPD/C/PER/CO/1 (2012) para 19.

52 CRPD Committee, General Comment No 1: Article 12: Equal Recognition before the Law, UN Doc CRPD/C/GC/1 (2014).

53 See eg Case of Alajos Kiss v Hungary, Application No 38832/06, Judgment, 20 May 2010 (ECtHR) (considering the impact of stereotyping on the voting rights of people with 
Committee, the introduction of an individual communication procedure ${ }^{54}$ will afford the CRPD Committee important opportunities to strengthen its consideration of stereotyping, examine the impact of stereotyping on individuals with disabilities, and interpret and apply the CRPD's stereotyping provisions. So far, however, only one communication has raised stereotyping as an issue for consideration and that communication was declared inadmissible on unrelated grounds..$^{55}$

A number of UN mechanisms outside the CRPD Committee have considered disability stereotyping, with many focusing their attention on compounded stereotyping of women and girls with disabilities. Perhaps unsurprisingly given the similarities between the CEDAW and CRPD provisions on stereotyping, many of those mechanisms have looked, and continue to look, to the CEDAW Committee for guidance in interpreting and applying the provisions in the latter treaty. To take one example, the UN Special Rapporteur on violence against women, its causes and consequences, looked both to the CRPD and CEDAW as well as the CEDAW Committee's jurisprudence, when analysing the linkages between stereotyping and violence against women and girls with disabilities. ${ }^{56}$ In her expert view, compounded gender and disability stereotyping influences the unique forms, causes and consequences of violence against women and girls with disabilities. She explained that ' $[w]$ omen with disabilities are at high risk of violence based on social stereotypes and biases that attempt to dehumanize or infantilize, exclude or isolate them, and target them for sexual and other forms of violence'. ${ }^{57}$ According to the Special Rapporteur, compounded stereotyping can also lead to adverse findings about the legal capacity and credibility of women and girls with mental disabilities in gender-based violence cases, such as

intellectual disabilities). See also Stephanie Ortoleva, 'Inaccessible Justice: Human Rights, Persons with Disabilities and the Legal System' (2011) 17(2) ILSA Journal of International and Comparative Law 281.

54 Optional Protocol to the Convention on the Rights of Persons with Disabilities (adopted 12 December 2006, entered into force 3 May 2008) GA Res 61/106, Annex II, UN GAOR, $61^{\text {st }}$ sess, Supp No 49, at 80, UN Doc A/61/49 (2006).

55 Kenneth McAlpine $v$ United Kingdom of Great Britain and Northern Ireland, Communication No 6/2011, UN Doc CRPD/C/8/D/6/2011 (2012). The communication concerned a man who claimed that the UK had failed to combat stereotypes of diabetics, which lead many employers, judges and other legal professionals to assume they take extended time off work due to their illness.

56 UNHRC, 'Report by Special Rapporteur on Violence against Women, its Causes and Consequences Rashida Manjoo' (2012) UN Doc A/67/227, paras 41, 76-84. On state obligations related to stereotyping and gender-based violence against women, see: Ramona Biholar, Transforming Discriminatory Sex Roles and Gender Stereotyping: The Implementation of Article 5(a) CEDAW for the Realisation of Women's Right to be Free From Gender-based Violence in Jamaica (Intersentia 2013); Rikki Holtmaat, 'Preventing Violence against Women: The Due Diligence Standard with Respect to the Obligation to Banish Gender Stereotypes on the Grounds of Article 5(a) of the CEDAW Convention' in Carin Benninger-Budel (ed), Due Diligence and its Application to Protect Women from Violence (Martinus Nijhoff, 2009) 63.

57 Manjoo, ibid para 32. 
when it operates to exclude or discount their testimony or their complaints are disregarded or disbelieved based on gender and disability stereotypes. ${ }^{58}$

Like the UN Special Rapporteur on violence against women, the CEDAW Committee has also examined compounded stereotyping of women and girls with disabilities. R.P.B. $v$ the Philippines, which concerned the rape of a 17-yearold girl who is both deaf and mute, provides a case in point. ${ }^{59}$ In its views, the Committee concluded that the Philippines violated CEDAW when, inter alia, the trial court acquitted the accused of rape on the basis of stereotypes. Because of stereotyping, it explained, the trial judge expected R.P.B. to respond to the attack in a certain way, formed a negative view of her credibility when she did not do so, and disregarded key facts of the case, such as the lack of consent and how R.P.B.'s age and disability influenced her response. ${ }^{60}$ While the Committee highlighted key passages of the trial judgment that evidenced gender stereotyping (see section 2.2.2 below), it was less explicit about the role that disability and age stereotyping played and the specific impact of the compounded gender, disability and age stereotypes at play in the case. Still, it recommended that the State Party ensure all sexual violence proceedings are conducted impartially, fairly and free from stereotypes based on the gender, age or disability of the victim/survivor. ${ }^{61}$ It also urged the State Party to provide regular training to judges and other legal professionals, so that stereotypes do not affect court proceedings and decision-making. ${ }^{62}$

Other mechanisms that have examined disability stereotyping (to a greater or lesser extent) include: the (then) UN Special Rapporteur on the right to education, who briefly considered the impact of disability stereotyping in his examination of the importance of inclusive education for people with disabilities; ${ }^{63}$ the UN Special Rapporteur on the right to safe drinking water and sanitation, who explored the relationship between stereotypes, prejudice and stigma and their impact on access to water and sanitation for people with disabilities, among others; ${ }^{64}$ and the (then) UN Special Rapporteur on the right to highest attainable standard of physical and mental health, who very briefly considered how stereotypes influence perceptions

\footnotetext{
58 Ibid paras 41, 59. See also Janine Benedet and Isabel Grant, 'More Than an Empty Gesture: Enabling Women with Mental Disabilities to Testify on a Promise to Tell the Truth' (2013) 25(1) CJWL 31; Janine Benedet and Isabel Grant, 'Hearing the Sexual Assault Complaints of Women with Mental Disabilities: Evidentiary and Procedural Issues' (2007) 52 McGill LJ 515; Janine Benedet and Isabel Grant, 'Hearing the Sexual Assault Complaints of Women with Mental Disabilities: Consent, Capacity, and Mistaken Belief’ (2007) 52 McGill LJ 243.

59 R.P.B. (n 31).

60 Ibid paras 8.9-8.10.

61 Ibid para 9(b)(iii).

62 Ibid para $9(\mathrm{~b})(\mathrm{iv})$.

63 UNHRC, 'Report by Special Rapporteur on the Right to Education Vernor Muñoz' (2007) UN Doc A/HRC/4/29, paras $11,36,39,82$.

64 UNHRC, 'Report by Special Rapporteur on the Human Right to Safe Drinking Water and Sanitation Catarina de Albuquerque’ (2012) UN Doc A/HRC/21/42, paras 26, 67.
} 
about whether or not people with intellectual disabilities are capable of living independently and making decisions for themselves. ${ }^{65}$

The increased interest in disability stereotyping, likely occasioned by the adoption of the CRPD, has been key in giving greater visibility to this type of stereotyping and in expanding UN discourses beyond the exclusive realm of gender stereotyping. Scrutiny of this particular type of stereotyping remains relatively new, however, and, in many ways, is still in its embryonic stages. Analysis of disability stereotyping is certainly nowhere near as systematic or robust as it is for gender stereotyping. Further work is accordingly needed to ensure the full spectrum of UN mechanisms is cognisant of disability stereotyping, and understands the broad-ranging impact it can have on the lives of people with disabilities. Further work is also needed to ensure that, wherever possible, UN mechanisms seize opportunities to scrutinise disability stereotyping, and articulate the nature and scope of state obligations to address such stereotyping, including its compounded forms. The leadership of the CRPD Committee will be critical in this regard, just as the CEDAW Committee's leadership has been key in giving greater visibility within the UN to the issue of gender stereotyping. The Special Rapporteur on the rights of persons with disabilities, a position created recently, also provides a crucial opening to turn attention, and a critical eye, to the issue of disability stereotyping. Significantly in this respect, the Special Rapporteur's mandate requires her ' $\mathrm{t}$ ] o raise awareness of the rights of persons with disabilities, to combat stereotypes, prejudices and harmful practices that hinder their opportunity to participate in society on an equal basis with others, to promote awareness of their positive contributions and to inform persons with disabilities about their rights'. ${ }^{66}$

\subsubsection{Other Types of Stereotyping}

UN mechanisms have responded to other types of stereotyping. Take stereotyping based on race or ethnicity as an example. ${ }^{67}$ The 2015 report of the UN Special Rapporteur on minority issues, which included a thematic discussion of hate speech and incitement to hatred against minorities in the media, contains one of the more thorough examinations of the other types of stereotyping. In her report, the Special Rapporteur identified stereotyping as a form of hate speech and named common stereotypes of minority groups (eg violent, untrustworthy, disloyal, dirty). ${ }^{68}$ She focused her examination on the role media plays in perpetuating

$65 \quad$ UNHRC, 'Report by Special Rapporteur on the Right of Everyone to the Enjoyment of the Highest Attainable Standard of Physical and Mental Health Paul Hunt' (2005) UN Doc E/CN.4/2005/51, para 15.

66 Resolution 26/20 Special Rapporteur on the Rights of Persons with Disabilities, UN Doc A/HRC/RES/26/20 (2014).

67 For a detailed analysis of UN responses to racial stereotyping, see chapter 6 in this volume.

68 UNHRC, 'Report by Special Rapporteur on Minority Issues Rita Izsák' (2015) UN Doc $\mathrm{A} / \mathrm{HRC} / 28 / 64$, paras 52, 62. 
stereotypes of minority groups and considered the resultant impact on human rights. In her expert view, stereotyping by the media can: nurture inaccurate and false assumptions and opinions that can result in discrimination and prejudices: stigmatise and dehumanise whole communities; cause virulent attacks; and incite violence against minority members. ${ }^{69}$ The Special Rapporteur used her report to underscore the importance of a pluralistic media and representation of minority groups in the mainstream media. ${ }^{70}$ She accordingly urged media outlets to maintain high standards of ethical journalism, report factually and impartially, avoid stereotyping, and implement programmes to train, recruit and support media workers from minority groups, including for challenging wrongful stereotyping of minority groups. ${ }^{71}$ The Special Rapporteur also stressed the importance of education for promoting understanding, respect and tolerance as a way of eliminating stereotypes and prejudices about minority groups. ${ }^{72}$

The Committee on the Elimination of Racial Discrimination is one of several other UN mechanisms that have grappled with stereotyping based on race or ethnicity. In its General Recommendation No 30 on discrimination against non-citizens, for example, it urged States Parties to counter stereotyping of non-citizen population groups and ensure that non-citizens are not subject to stereotyping in the fight against terrorism. ${ }^{73}$ It has also encouraged States Parties to adopt measures to challenge stereotyping of Roma people. ${ }^{74}$ And in its General Recommendation No 35 on hate speech, the Committee noted the importance of the freedom of expression for deconstructing racial stereotypes and urged States Parties to adopt policies to empower all groups to exercise this freedom. ${ }^{75}$ It also stressed the need to ensure media representations of minority groups are based on 'principles of respect, fairness and the avoidance of stereotyping. ${ }^{76}$

Notwithstanding these and a number of further interventions on other types of stereotyping, the issue of stereotyping has gained only limited traction outside of gender stereotyping and, to a lesser extent, disability stereotyping. For this reason, there has been comparatively little visibility of other types of stereotyping within the UN and the responses of UN mechanisms to these types of stereotyping have been mostly weak and ad hoc. This is evident from the infrequent attention given to, and basic analysis of, other types of stereotyping during the past five or so

\footnotetext{
$69 \quad$ Ibid paras 62-63.

Ibid paras 64-70.

Ibid para 110 .

Ibid para 115 .

Committee on the Elimination of Racial Discrimination (CERD), General Recommendation No 30: Discrimination against Non-Citizens, UN Doc CERD/C/GC/35 (2005) paras 10, 12.

74 CERD, Concluding Observations: Belarus, UN Doc CERD/C/BLR/C0/18-19 (2013) para 16; CERD, Concluding Observations: Finland, UN Doc CERD/C/FIN/CO/20-22 (2012) para 17; CERD, Concluding Observations: Serbia, UN Doc CERD/C/SRB/CO/1 (2011) para 16; CERD, Concluding Observations: Romania, UN Doc CERD/C/ROU/CO/16-19 (2010) para 16.

75 CERD, General Recommendation No 35: Combating Racist Hate Speech, UN Doc CERD/G/ GC/35 (2013) para 29.

76

Ibid para 40 .
} 
years. The absence of express human rights obligations concerning stereotyping in treaties other than CEDAW and the CRPD is undoubtedly a reason for the more limited focus on these other types of stereotyping, although it bears repeating that ICERD contains an express obligation to combat prejudice, a related and sometimes overlapping problem. ${ }^{77}$ It also bears repeating that almost all human rights treaty bodies have recognised implied obligations to address stereotyping, including as part of the rights to non-discrimination and equality. ${ }^{78}$ Yet it would appear that there is only limited awareness of those obligations, as evidenced in the infrequent and passing references made to them by many UN mechanisms.

What's more, human rights treaty bodies that have themselves recognised the implied obligations are missing opportunities to hold States Parties accountable for relevant violations. An example is the decision of the HRC in L.N.P. v Argentine Republic, ${ }^{79}$ which concerned discrimination against, and the gang rape of, a 15-year-old girl from the Qom ethnic group in Argentina. The HRC concluded in that case that the trial court's decision to acquit the perpetrators of rape constituted a violation of the right to non-discrimination in the International Covenant on Civil and Political Rights ${ }^{80}$ (ICCPR). ${ }^{81}$ It explained that the trial court had invoked discriminatory and offensive criteria to cast doubt on the girl's morality (ie the fact that she was not a virgin and suggestions that she was a sex worker), which led it to conclude that the girl had failed to prove lack of consent. Although the HRC ultimately found violations of the ICCPR, nowhere in its views did it identify the role that stereotyping - for instance, gender and/or ethnic stereotyping - played in the decision to acquit, or articulate which stereotypes the court relied on..$^{82}$ This is in spite of recognising in its General Comment No 28 that the ICCPR requires States Parties to ensure that stereotyping does not affect women's legal rights and protections, including against rape. ${ }^{83} \mathrm{Had}$ the HRC examined the role of stereotyping, it would have been able to challenge the practice and the operative stereotypes, urge the State Party to take appropriate action, and help to ensure that other survivors of rape are not vulnerable to the same stereotyping by the Argentinian judicial system.

It is clear that more needs to be done to raise awareness amongst UN mechanisms of the existence, nature and scope of the full range of human rights obligations related to stereotyping. As more mechanisms are made aware of the full extent of international obligations related to stereotyping and as they turn their attention to examining the various types of stereotyping, the visibility (and

ICERD Art 7.

See notes 6-12 above and accompanying text.

L.N.P. v Argentine Republic, Communication No 1610/2007, UN Doc CCPR/C/102/D/1610/2007 (2011).

80 International Covenant on Civil and Political Rights ICCPR (adopted 16 December 1966, entered into force 23 March 1976) 999 UNTS 171 (ICCPR).

L.N.P. (n 79) paras 13.3, 13.8 .

Ibid para 13.3.

Human Rights Committee, General Comment No 28 (n 11) para 20. 
scrutiny) of this issue within the UN will grow even further and UN responses to this issue will likely also grow in number and strength. Importantly, this will serve to reinforce stereotyping's place as an issue deserving of attention from all UN human rights mechanisms.

\subsection{ANALYSIS OF GENDER STEREOTYPING IS MORE SOPHISTICATED}

At the same time as the visibility of gender (and, to a lesser extent, disability) stereotyping has increased, the analysis of gender stereotyping has also grown in sophistication, particularly amongst UN mechanisms that have been engaging with it for a long time. Rather than simply identifying gender stereotyping as a root cause of women's rights violations and perhaps urging states to introduce education initiatives or work with the media to challenge stereotyping, as might once have been the case, these mechanisms are now beginning to engage with the issue in a more critical and in-depth way. Given its considerable work on gender stereotyping, it is unsurprising that the quality of the CEDAW Committee's analysis of stereotyping has grown most markedly. Two areas where this is particularly evident are the more nuanced language the Committee is using when it engages with gender stereotyping and its more comprehensive examination of stereotyping, including its resultant harms to women.

\subsubsection{The Language Used to Engage with Gender Stereotyping is More Nuanced}

The language the CEDAW Committee is using to describe state obligations to address gender stereotyping has become more nuanced over time. An examination of the Committee's early jurisprudence on gender stereotyping shows that it would often urge States Parties to 'abolish' or 'eliminate' gender stereotypes and the practice of gender stereotyping. ${ }^{84}$ Yet the Committee's views in R.K.B. $v$ Turkey signalled a change in approach. In that case, the Committee explained that CEDAW'requires States parties ... to modify and transform gender stereotypes and eliminate wrongful gender stereotyping. ${ }^{85}$ In doing so, it appears to have drawn a distinction between state obligations concerning stereotypes (ie the belief) on the one hand and those obligations concerning stereotyping (ie the practice of applying the belief to individuals) on the other.

According to the Committee, CEDAW requires States Parties to take steps to change stereotypical beliefs (ie modify or transform), but it does not require them to go further by eradicating such beliefs. In adopting this view, the Committee appears to have recognised that there may be an inherent incompatibility with

\footnotetext{
84 See eg CEDAW Committee, General Recommendation No 3 (n 13).

${ }_{85} \quad$ R.K.B. (n 7) para 8.8 .
} 
the freedom of expression (and even other human rights) in requiring states to abolish or eliminate a belief. Yet, at the same time, it seems to have recognised the importance of changing stereotypical beliefs that are harmful, for instance those that cause holders of stereotypical beliefs to assume that the subject group is inferior to other groups and which incite violence against individual group members. Under this new approach, the Committee has also taken the view that CEDAW requires States Parties to do more than simply modify or transform the practice of stereotyping; they must actually put an end to the practice of applying stereotypical beliefs to individuals, when doing so violates human rights and fundamental freedoms.

It is not yet clear whether other UN mechanisms will make the same distinction as the one drawn by CEDAW Committee. Interestingly, the CRPD Committee has not done so in its early jurisprudence on stereotyping, preferring, instead, to use the terms 'combat' and 'eliminate' interchangeably to describe state obligations to address disability stereotypes and disability stereotyping. ${ }^{86}$ There are, however, some very early signs that the language the CEDAW Committee is using to differentiate between state obligations in respect of gender stereotypes and gender stereotyping is beginning to be replicated more broadly with the UN system, including within the Human Rights Council. ${ }^{87}$

As with state obligations, the language the CEDAW Committee uses to describe the resultant harms of stereotyping has become more nuanced. Through its Optional Protocol jurisprudence, it has clarified that CEDAW is concerned with 'harmful's8 stereotypes and 'wrongful's9 stereotyping. Put simply, in its expert view, CEDAW addresses stereotypes and stereotyping that affect recognised human rights, rather than all stereotypes and all types of stereotyping. Although other UN mechanisms have not been so explicit in their discussion of this issue, their focus has undoubtedly remained on those stereotypes and types of stereotyping that in one way or another impair or nullify the recognition, exercise and enjoyment of human rights, as the examples used in this chapter show. Assuming other UN mechanisms accept the approach adopted by the CEDAW Committee, two questions will need to be answered moving forward. Firstly, when is a stereotype considered to be 'harmful'? And, secondly, when is stereotyping 'wrongful'?'0

$86 \quad$ See eg CRPD Committee, Concluding Observations: Tunisia, UN Doc CRPD/C/TUN/CO/1 (2011) para 15(a); CRPD Committee, Concluding Observations: Peru, UN Doc CRPD/C/PER/ CO/1 (2012) para 19.

87 See eg Navi Pillay, 'Opening Remarks', The Impact of Gender Stereotypes on the Recognition and Enjoyment of Women's Human Rights, Annual Full Day Discussion on Women's Human Rights, Human Rights Council, 26 ${ }^{\text {th }}$ sess, Geneva, 17 June 2014.

88 V.V.P. v Bulgaria, Communication No 31/3011, UN Doc CEDAW/C/53/D/31/2011 (2012) para 9.6 (emphasis added).

$89 \quad$ R.K.B. (n 7$)$ para 8.8 .

90 For an early consideration of these terms, see Cusack (n 5) 18-19. 


\subsubsection{Analysis of the Impact of Stereotyping is More In-Depth}

The CEDAW Committee's examination of the impact of stereotyping is another area where the sophistication of its analysis has grown considerably. Contrasting the Committee's views in A.T. $v$ Hungary ${ }^{91}$ with its more recent views in R.P.B. $v$ the Philippines, ${ }^{92}$ both gender-based violence cases, provides a stark illustration of how it is engaging with the issue of stereotyping in greater detail. In 2005, the Committee held Hungary accountable for its failure, over a period of more than four years, to protect A.T. effectively against her abusive former partner. ${ }^{93}$ In 2014, it held the Philippines accountable for a trial court's decision to acquit a man of raping his 17-year-old neighbour, who is both mute and hearing impaired. ${ }^{94}$ Although the Committee found stereotyping-related violations of CEDAW in both these cases, its analysis of the issue varied considerably.

In upholding A.T.'s claim, the Committee affirmed that gender stereotyping is a root cause of gender-based violence within Hungary and condemned its failure to address this harmful practice. ${ }^{95}$ The Committee also recalled that it had identified harmful stereotypes when it considered the State Party's periodic report in 2002 and explained that these were the same stereotypes that had contributed to the violence experienced by A.T. ${ }^{96}$ Whilst the identification of the link between stereotyping and domestic violence was a welcome development, the CEDAW Committee missed a valuable opportunity in this case to name the specific gender stereotypes that contributed to the violence against A.T. It also missed an opportunity to explain how those stereotypes enabled domestic violence against her and how they had been perpetuated within the State Party. What's more, the Committee did not avail itself of the opportunity to articulate the nature and scope of state obligations to address stereotyping that facilitates domestic violence, or make recommendations as to how the State Party should address such stereotyping. ${ }^{97}$

Fast-forwarding almost ten years to R.P.B. $v$ the Philippines, the CEDAW Committee criticised the trial court for basing the decision to acquit on gender and disability stereotypes, rather than on law and fact..$^{98}$ In doing so, it identified several stereotypes relied upon by the trial court and singled out key passages of the court's decision where they had been applied. For instance, the suggestions that a Filipina rape victim would 'summon every ounce of her strength and courage to thwart any attempt to besmirch her honour and blemish her purity', ${ }^{99}$ and the

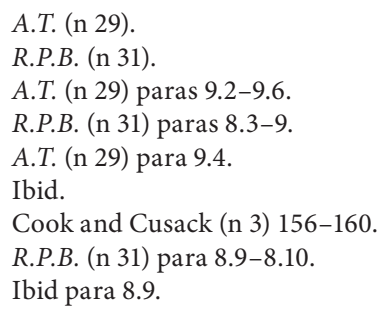


court's finding that R.P.B.'s 'demeanour was inconsistent with that of an ordinary Filipina' and the 'reasonable standard of human conduct' because she had not physically resisted the attack or sought to escape. ${ }^{100}$ The CEDAW Committee then examined the impact of the court's reliance on stereotypes on its decision to acquit. In doing so, the Committee explained that the court formed a negative view of R.P.B.'s credibility because she had not responded to the rape in line with the operative stereotypes. ${ }^{101}$ It further explained that the court's reliance on those stereotypes caused it to disregard key facts, including her age and disability, which supported the allegations made by R.P.B., including why she did not physically resist or call for help during the assault. ${ }^{102}$ Lastly, the Committee spelt out the obligations of States Parties concerning judicial stereotyping and made several related recommendations, including that the Philippines take steps to ensure that all sexual violence proceedings are conducted fairly and impartially, and free from stereotypes. ${ }^{103}$

The growing sophistication of analyses of stereotyping is a crucial development in UN responses to this issue. Even so, most of the progress in this area has been limited to the CEDAW Committee. While the evolution of the Committee's analysis is significant and is helping to inform broader UN responses to stereotyping, it is essential that other UN mechanisms follow the Committee's lead and expand the quality of their analyses of this issue.

\subsection{THE OHCHR IS PLAYING A LEADERSHIP ROLE ON STEREOTYPING}

UN responses to stereotyping have been strengthened by the recent leadership shown by the OHCHR and the former High Commissioner for Human Rights. In March 2014, the (then) High Commissioner said the OHCHR would devote 'considerable attention to providing more robust guidance'104 on the issue. In line with this commitment, the OHCHR has incorporated stereotyping into its 20142017 management plan, established a webpage on stereotyping, ${ }^{105}$ and helped facilitate a panel on this issue at the Human Rights Council annual women's rights discussion in 2014. In a further demonstration of the Office's commitment to this issue, the former High Commissioner, when delivering her opening address at

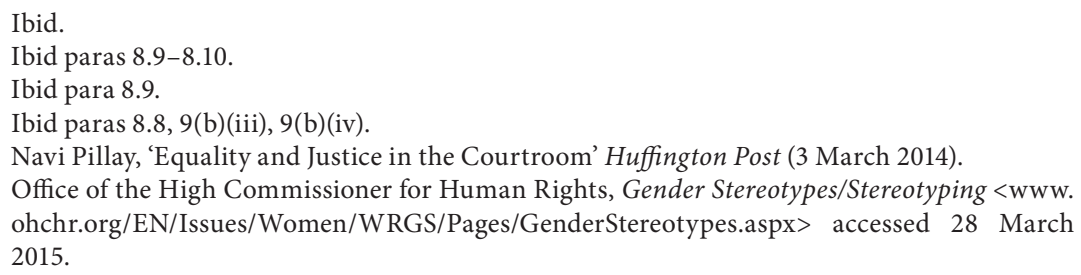


the Council's panel discussion, acknowledged that stereotyping 'is an important human rights concern'. ${ }^{106}$

Additionally, the OHCHR commissioned two research projects on stereotyping. The first examined how international human rights treaties and UN mechanisms have addressed stereotyping, ${ }^{107}$ and identified strategies the Office could adopt to assist efforts to challenge this practice. ${ }^{108}$ The second project explored the negative impact of judicial stereotyping on gender-based violence cases, identified strategies for addressing it and highlighted good practice examples of their use. ${ }^{109}$ Expanding its focus on stereotyping to include other aspects of the criminal justice system, the OHCHR is now working with the Republic of Moldova to help it de-codify stereotypes from its Prosecutorial Guidelines for Investigation and Prosecution of Acts of Sexual Violence. ${ }^{110}$ It is also analysing gender-based violence judgments of ordinary and specialist violence courts in Guatemala and El Salvador for evidence of stereotyping and taking steps to help build judicial capacity to challenge this practice. ${ }^{111}$ More broadly, the OHCHR's field offices in Cambodia and Moldova have included the issue of stereotyping in their in-country human rights training. ${ }^{112}$

Although still in its early stages, the OHCHR's leadership has been instrumental already in elevating stereotyping on the UN agenda. The Human Rights Council panel on stereotyping, which was a recommendation of the Office's first project, is a clear example of this. Another example is the work the Office is undertaking to include stereotyping in a checklist for the preparation of reports for the Universal Periodic Review process. ${ }^{113}$ But more than just helping to raise the profile of stereotyping, the Office - particularly through mapping relevant human rights obligations and identifying strategies for challenging this practice - is providing needed guidance in this area, something for which there is a strong

$106 \quad$ Pillay (n 104), 2.

107 Cusack (n 5).

108 Simone Cusack, Strategies for Addressing Gender Stereotyping: Policy Paper, Commissioned by the UN Office of the High Commissioner for Human Rights (2013).

109 Simone Cusack, Eliminating Judicial Stereotyping: Equal Access to Justice for Women in Genderbased Violence Cases, Commissioned by the UN Office of the High Commissioner for Human Rights(2014)<www.ohchr.org/Documents/Issues/Women/WRGS/judicial_stereotyping2014. docx $>$ accessed 28 March 2015.

110 In 2013, the CEDAW Committee expressed concern about the low rate of reporting, and ineffective investigation and prosecution, of sexual violence cases in the Republic of Moldova. It subsequently recommended that the State Party ensure that investigations into allegations of sexual violence are carried out in accordance with international standards. In particular, the Committee urged the State Party to amend its Prosecutorial Guidelines for Investigation and Prosecution of Acts of Sexual Violence. See CEDAW Committee, Concluding Observations: Republic of Moldova, UN Doc CEDAW/C/MDA/CO/4-5 (2013) paras 19-20. The Republic of Moldova is now reviewing the guidelines and the $\mathrm{OHCHR}$ has sought to aid the reform process by providing expert guidance on international human rights law, including in relation to the issue of stereotyping.

111 Statement by Veronica Birga (personal email correspondence 19 January 2015).

112 Statement by Adwoa Kufuor (personal email correspondence 20 January 2015).

113 Statement by Veronica Birga (personal email correspondence 19 January 2015). 
appetite, particularly amongst member states. ${ }^{114}$ Importantly, the OHCHR is also helping to build capacity amongst, and providing critical support to, UN human rights mechanisms to address stereotyping through their respective mandates. For instance, it has prepared a short briefing note on stereotyping, which was distributed to new special procedure mandate holders and soon will be made available to other mandate holders and treaty body experts. ${ }^{115}$ It is hoped this will serve as a starting point for UN mechanisms keen to learn more about stereotyping and how they could address this issue usefully through their work.

\section{STRATEGIES FOR STRENGTHENING UN RESPONSES TO STEREOTYPING}

Although many UN mechanisms, and particularly the CEDAW Committee, have improved how they respond to stereotyping over the past half-decade, there are nevertheless still considerable opportunities for strengthening those responses. Section 3 reflects briefly on some of the ongoing weaknesses in how UN mechanisms are responding to stereotyping, specifically: the failure of many mechanisms to identify stereotypes accurately; the limited guidance on state obligations, particularly obligations in treaties other than CEDAW; and the lack of information about good practice examples of challenging stereotyping. At the same time, section 3 identifies several strategies that, if implemented, could help to overcome these shortcomings and, ultimately, strengthen UN responses to stereotyping. In this connection, it: calls for greater efforts to build the capacity of UN mechanisms to understand and identify stereotypes accurately; urges UN mechanisms to elaborate state obligations related to stereotyping; and recommends that UN mechanisms identify and highlight practices that are bringing about positive change in relation to stereotyping.

\subsection{BUILD CAPACITY TO UNDERSTAND AND IDENTIFY STEREOTYPES ACCURATELY}

\subsubsection{Failure to Identify Stereotypes Accurately}

A weakness of current approaches to stereotyping is that when UN human rights mechanisms address stereotyping, they often do not identify operative stereotypes accurately. ${ }^{116}$ Sometimes they mislabel related, but distinct, concepts such as myths

\footnotetext{
114 See eg Statements of the governments of Estonia, Nepal and Ireland, The Impact of Gender Stereotypes on the Recognition and Enjoyment of Women's Human Rights, Annual Full Day Discussion on Women's Human Rights, Human Rights Council, $26^{\text {th }}$ sess, Geneva, 17 June 2014.

115 Statement by Veronica Birga (personal email correspondence 19 January 2015).

116 Cusack (n 5) 65-67.
} 
(eg most perpetrators of rape are strangers) and prejudices (eg women are inferior to men), as stereotypes. Other times they identify the assumption underpinning the stereotypical belief, rather than the stereotype itself. For example, identifying the assumption that 'women bear the responsibility for sexual attacks or invite them by being out late or in isolated places or by dressing in a particular manner, ${ }^{117}$ rather than the stereotypes that 'women should be modest' (which may cause its holder to assume that immodest women invite sexual assaults).

The problem with mislabelling stereotypes or failing to identify them accurately is that it creates confusion about the actual problem threatening human rights - the stereotype and/or its application to an individual in the form of stereotyping. This leads to the concealment of the specific belief that needs to be modified or transformed and the practice that needs to be eliminated because it violates human rights. It also potentially diverts attention and resources away from efforts to challenge wrongful stereotyping. That, of course, is not to say that prejudices, myths and the assumptions underpinning stereotypes do not also warrant attention; they do. ${ }^{118}$ However, the full implementation of international human rights obligations related to stereotyping requires UN mechanisms to be very clear about the specific stereotypes that are undermining the recognition, exercise and enjoyment of human rights. This means that they must be able to identify the attributes, characteristics and/or roles that have been ascribed to individuals as a result of stereotyping.

\subsubsection{Build Capacity of UN Mechanisms}

Further work is therefore needed to build the capacity of UN mechanisms to understand, identify and challenge stereotypes and ensure they do not perpetuate them through their work. Whilst there is a substantial body of work on stereotyping in marriage and family relations, there is a particular need to build capacity to name the stereotypes that operate in other areas of life (eg the military, health). What, for example, are some of the common stereotypes that operate in those areas? How have those stereotypes been perpetuated?119 What has been the impact on human rights (eg impeding the promotion of women in the military)? ${ }^{120}$ And what strategies have proven successful in challenging stereotyping in those areas and are there any good practice examples of the strategies being used in practice?

\footnotetext{
117 UNHRC, 'Report by Special Rapporteur on the Independence of Judges and Lawyers Gabriela Knaul' (2011), UN Doc A/66/289, para 48.

118 See eg John F Dovidio, Peter Glick and Laurie Rudman, On the Nature of Prejudice: Fifty Years after Allport (Blackwell Pub 2005); Gorgon W Allport, The Nature of Prejudice (AddisonWesley Pub Co 1954).

119 See eg Raewyn Connell and Rebecca Pearce, Gender Norms and Stereotypes: A Survey of Concepts, Research and Issues about Change, UN Women, Expert Group Meeting, Envisioning Women's Rights in the Post-2015 Context, EGM/B20/BP.2 (2014) 10-30. See ch 8 in this volume.
} 
Whilst the UN mechanisms need to make a concerted effort to educate themselves and others about stereotypes, including, for instance, through General Recommendations and their reports to the Human Rights Council, there is also an important role for the OHCHR (and others) to play in this area. As explained above, the Office is currently working to build capacity around the issue of stereotyping, including through its briefing note on stereotyping for treaty body experts and special procedures and its paper on eliminating judicial stereotyping. It should also explore opportunities to support UN special procedures and treaty bodies wishing to address stereotyping through their reports and jurisprudence. ${ }^{121}$ This might involve facilitating training and the publication or distribution of resources providing crucial guidance on stereotyping and how to recognise, articulate and challenge stereotypical beliefs. The OHCHR should also explore opportunities to promote the important work that UN mechanisms have already completed, and that they continue to complete, on stereotyping, including through its stereotyping webpage. In addition to the work undertaken on this issue by treaty bodies such as CEDAW, it might be useful to highlight the reports of those UN Special Rapporteurs that have addressed this issue through their mandates. ${ }^{122}$

As well as the $\mathrm{OHCHR}$, human rights advocates and others can play a key role in building the capacity of UN mechanisms to address stereotyping, including through the accurate identification of the nature and scope of the problem. The International Commission of Jurists is, for example, developing a resource on eradicating stereotypes from laws and practices related to sexual violence against women, which usefully identifies common stereotypes in this area. ${ }^{123}$ Although this initiative does not target UN mechanisms specifically, it illustrates the important role that human rights advocates can play in building capacity around the issue of stereotyping and ensuring that the problem is identified accurately and understood better.

\subsection{ELABORATE STATE OBLIGATIONS RELATED TO STEREOTYPING}

\subsubsection{Limited Guidance on State Obligations Related to Stereotyping}

UN mechanisms have provided some useful guidance on the nature and scope of human rights obligations related to stereotyping. Nevertheless, the increased

$\overline{121 \quad \text { Cusack (n 108) }}$ paras 3.1-4.5.

122 See eg Knaul (n 117); UNHRC, 'Report by Special Rapporteur in the Field of Cultural Rights Farida Shaheed' (2012), UN Doc A/67/287; Sepúlveda Carmona (n 38).

123 See eg International Commission of Jurists, Sexual Violence against Women: Eradicating Gender Stereotypes in Laws and Practice. Distilling the Issues \& Pointing to Comparative Good Practices (draft, 2014) (on file with author). 
scrutiny of this issue has exposed significant gaps in the guidance provided to date. The limited awareness of relevant obligations contained in treaties other than CEDAW is particularly noteworthy in this regard. Many states are consequently unsure about the steps they should take to implement their obligations fully, which is undermining efforts to modify or transform harmful stereotypes and eliminate wrongful stereotyping. For instance, what measures are required under the CRC to challenge age-based stereotyping? Similarly, what steps must states take to modify or transform harmful stereotypes based on sexual orientation?

\subsubsection{Elaborate State Obligations Related to Stereotyping}

The gaps that have been exposed evidence a need for more comprehensive information on the nature and scope of the full range of human rights obligations related to stereotyping. ${ }^{124}$ In light of its considerable work on stereotyping thus far, further, detailed guidance on state obligations would initially best come from the CEDAW Committee. A General Recommendation, informed by a 'general day of discussion', ${ }^{125}$ would be most suited to this goal, owing to the significant scope it affords the Committee to articulate the extent of CEDAW's obligations to address stereotyping. At a minimum, the General Recommendation should: identify how stereotypes and stereotyping violate CEDAW; explain the nature and scope of state obligations in Articles 2(f), 5 and 10(c) of CEDAW, including when they are read with Articles 6 to 16; elaborate the linkages between those obligations and the fulfilment of CEDAW's overarching goals of eliminating discrimination and achieving equality; and clarify the effect of reservations to Articles 2(f) and 5. It might also address related concepts such as prejudice ${ }^{126}$ and stigma ${ }^{127}$ and their relationship to CEDAW. The CEDAW Committee's earlier recommendations on stereotyping, particularly under the Optional Protocol, should also feature prominently in the General Recommendation. Furthermore, it is important that the Committee continues to articulate the nature and scope of state obligations to address stereotyping through its work on other substantive issues. It is pleasing, for this reason, that the Committee's General Recommendation No 33 on women's access to justice for women includes a number recommendations on stereotyping, including adopting mechanisms to ensure rules of evidence, investigations and

$124 \quad$ Shaheed (n 122) paras 43-44.

125 The CEDAW Committee has already held general days of discussions on topics such as women's right to education, rural women, access to justice, women in conflict and postconflict situations, and harmful practices. State obligations to address stereotyping have been considered briefly during these days of discussion. See CEDAW Committee <www.ohchr.org/ EN/HRBodies/CEDAW/Pages/CEDAWIndex.aspx> accessed 28 March 2015.

126 For a general analysis of the impact of prejudice, see Dovidio, Glick and Rudman (n 118); Allport (n 118).

127 For an analysis of the impact of stigma on women in the context of abortion, see Rebecca J Cook, 'Stigmatized Meanings of Criminal Abortion Law' in Rebecca J Cook, Joanna N Erdman and Bernard M Dickens, Abortion Law in Transnational Perspective (University of Pennsylvania Press 2014) 347. 
other legal and quasi-judicial procedures are impartial and not influenced by stereotypes. ${ }^{128}$ It is also pleasing that its recent General Recommendations on harmful practices and the gender-related dimensions of refugee status, asylum, nationality and statelessness of women deal with this issue. ${ }^{129}$

Whilst further guidance from the CEDAW Committee would be a critical step forward in addressing gaps in information about the nature and scope of state obligations, it will not by itself provide adequate guidance on the stereotyping obligations contained in treaties other than CEDAW or in relation to those types of stereotyping based on grounds other than sex/gender. It is therefore incumbent on all UN mechanisms to consider how they, too, can elaborate state obligations to address stereotyping. Already, some UN mechanisms have begun to elucidate the nature and scope of state obligations in this area. For example, the 2010 report of the UN Special Rapporteur on freedom of religion or belief highlighted how schools can help to eliminate harmful stereotypes and other prejudices that affect members of religious minorities. ${ }^{130}$ In a further example, the 2012 report of the Special Rapporteur on the human right to safe drinking water and sanitation identified several measures states should take to challenge stereotyping that stigmatises certain groups and undermines their access to safe water and sanitation. ${ }^{131}$

Examples such as these are, however, all too rare. As such, they underscore the need for a greater commitment from UN mechanisms to articulate the full range and extent of state obligations related to stereotyping. Not only would this help to address critical gaps in information about state obligations, but it also has the potential to stimulate and enrich transnational discourses about all types of stereotyping.

\subsection{HIGHLIGHT GOOD PRACTICE EXAMPLES OF CHALLENGING STEREOTYPING}

\subsubsection{Limited Awareness of Effective Responses to Stereotyping}

As awareness of stereotyping has begun to grow, so has interest in good practices in challenging stereotyping. Evidence of this interest was clear during the

128 CEDAW Committee, General Recommendation No 33 on women's access to justice, UN Doc CEDAW/C/GC/33 paras 3, 7-8, 18, 21, 26-35, 51(h), 65(h), 66.

129 CEDAW Committee, General Recommendation No 32 (n 18) paras 31, 44; CEDAW Committee and the Committee on the Rights of the Child, Joint General Recommendation/General Comment No 31 of the Committee on the Elimination of Discrimination against Women and No 18 of the Committee on the Rights of the Child on Harmful Practices, UN Doc CEDAW/C/ GC/31-CRC/C/GC/18 (2014) paras 6, 17, 29, 39, 67, 69(c).

130 UNHRC, 'Report by Special Rapporteur on Freedom of Religion or Belief Heiner Bielefeldt' (2010) UN Doc A/HRC/16/53, paras 27-40, 58.

131 De Albuquerque (n 64) paras 18, 20, 22, 29, 31, 35, 44, 64-69, 82(c)(iii). 
Human Rights Council's 2014 annual discussion on women's human rights, when a number of governments enquired about practices that are helping to dispel stereotypes and prevent their application to individuals. For instance, the Government of Ireland asked how it could best support young girls to grow up without internalising harmful stereotypes, and the Government of Nepal asked how regional mechanisms could help to challenge stereotyping at the national level. ${ }^{132}$ It is not just states that have an appetite for information about good practices in challenging stereotyping, but also UN mechanisms and other human rights advocates. For example, in discussing stereotyping in her 2012 report, the Special Rapporteur on the field of cultural rights lamented the lack of 'sufficient information on best practices ... at the national level'. ${ }^{133}$ She went on later in her report to issue a call to governments, national human rights institutions and nongovernmental organisations, to gather examples of such practices. ${ }^{134}$

The interest in good practices is understandable given the size and complexity of the challenges involved in modifying or transforming harmful stereotypes and eliminating wrongful stereotyping. How, for instance, should a state set about transforming a belief or set of beliefs that have become so ingrained as to be considered a 'normal' aspect of daily life (eg women should be caregivers; men should be breadwinners)? Which strategies have already proven useful in bringing about, or initiating, that transformation? What worked well, and what were the risks and challenges in implementing them, and how were they overcome?

\subsubsection{Identify and Highlight Measures that are Bringing about Positive Change}

It is important that more UN mechanisms respond to, and capitalise on, the interest in good practices, by identifying and highlighting measures that are bringing about positive change in relation to stereotyping. The OHCHR's recent paper on judicial stereotyping illustrates one way that UN mechanisms could seek to make a contribution in this area. ${ }^{135}$ A key aim of the Office's paper was to identify strategies to challenge judicial stereotyping as well as good practice examples of their use in cases involving gender-based violence. Some of the strategies highlighted include laws and policies that prohibit and sanction judicial stereotyping, rules of evidence and procedure that limit opportunities for judicial stereotyping, legal decisions that challenge stereotyping by lower courts and resources and training that build judicial capacity to address stereotyping. One example highlighted in the paper was rule 96 of the rules of procedure and evidence of the International Tribunal for Rwanda, which seeks to prevent judicial

\footnotetext{
132 The Impact of Gender Stereotypes on the Recognition and Enjoyment of Women's Human Rights, Annual Full Day Discussion on Women's Human Rights, Human Rights Council, $26^{\text {th }}$ sess, Geneva, 17 June 2014.

$133 \quad$ Shaheed (n 122) para 54.

134 Ibid para 83.

135 Cusack (n 109).
} 
stereotyping by providing that a sexual assault victim's testimony does not need to be corroborated and prohibiting prior sexual conduct from being admitted in evidence or as a defence. ${ }^{136}$ Another example comes from the Gender Equality Unit of the Mexican National Supreme Court of Justice, which has provided crucial guidance on how judges can avoid and challenge stereotyping in its protocol on incorporating a gender perspective into judicial decision-making. ${ }^{137}$ The Unit's monitoring of the implementation of the protocol will be critical in evaluating its success in ensuring judges refrain from stereotyping in their decisions and challenge it where it does occur.

\section{CONCLUSION}

The international human rights landscape is vastly different today than it was just five or six years ago insofar as the issue of stereotyping is concerned. The biggest change, though, has been the growing attention given to gender and, increasingly but to a far lesser extent, disability stereotyping. More and more regularly, UN human rights mechanisms are identifying instances of gender and disability stereotyping and examining in greater depth how those types of stereotyping are undermining the human rights of women and people with disabilities. This attention has, in turn, been crucial in deepening understanding of gender and disability stereotyping and improving the quality of UN responses to those types. Importantly, it has also been key in helping to identify, and build momentum towards, solutions capable of bringing about real change in modifying or transforming harmful gender and disability stereotypes, and eliminating wrongful gender and disability stereotyping. Of course, it is ultimately up to states, and not UN human rights mechanisms, to tailor and implement these solutions through their laws, policies, programmes and practices. Nevertheless, the expanding discourse on gender and disability stereotyping, and the heightened scrutiny of this issue amongst UN human rights mechanisms more broadly will undoubtedly apply pressure on, and help to motivate, states to take the steps needed to safeguard human rights against harmful gender or disability stereotypes and wrongful gender or disability stereotyping.

A challenge moving forward will be further expanding and deepening UN discourses on stereotyping to address better those types of stereotyping based on grounds other than gender and disability. Whilst existing UN jurisprudence on stereotyping will provide a useful starting point for this further evolution, it is ultimately the responsibility of all UN mechanisms to seize opportunities to address stereotyping as part of their respective mandates and, where mandates

$136 \quad$ International Criminal Tribunal for Rwanda, Rules of Procedure and Evidence (rev 2013) r 96.

137 Gender Equality Unit, National Supreme Court of Justice, Mexico, Judicial Decision-Making with a Gender Perspective: A Protocol. Making Equal Rights Real (2014). 
permit, hold states accountable for their failure to modify or transform all harmful stereotypes and eliminate all wrongful stereotyping. As responses to stereotyping grow further in strength, it will be important for UN mechanisms to consider opportunities for collaboration and coordination, including on critical questions like the content, scope and limitations of state obligations. What is clear for now is that the issue of stereotyping is on the UN's human rights agenda and that UN mechanisms need to take advantage of the momentum generated over the past half-decade to further strengthen and expand their responses to stereotyping. 


\title{
GENDER STEREOTYPING IN DOMESTIC VIOLENCE CASES
}

\section{An Analysis of the European Court of Human Rights' Jurisprudence}

\author{
Lourdes Peroni and Alexandra Timmer
}

\begin{abstract}
Stereotyping has definitely appeared on the radar of the European Court of Human Rights (ECtHR, the Court or the Strasbourg Court). In several recent rulings, notably the Grand Chamber judgments of Konstantin Markin v Russia ${ }^{1}$ and Aksu v Turkey, ${ }^{2}$ the Court has taken issue with gender-based and race-based stereotypes. Konstantin Markin concerned Russia's refusal to grant parental leave to a military serviceman. This is an important ruling, because the Court held that the state could not rely on gender stereotypes to justify differences in treatment between men and women under Article 14 of the European Convention on Human Rights (ECHR). ${ }^{3}$ Aksu concerned government-sponsored publications, which included derogatory stereotypes about Roma. The importance of this judgment, as seen from an anti-stereotyping perspective, is that the Court explicitly recognises that stereotyping can negatively impact the right to private life (Article 8 ECHR).

In this chapter, rather than comprehensively analysing and critiquing the ways in which the Strasbourg Court addresses (and fails to address) stereotypes, ${ }^{4}$ we zoom in on the Court's case law regarding domestic violence against women. In a volume dedicated to exploring the ways in which stereotyping is a human rights issue, violence against women (VAW) - and specifically domestic violence against women - is a particularly salient and thorny issue. International human rights law - as will be discussed further below - recognises that there are close links
\end{abstract}

Konstantin Markin v Russia (2012) 56 EHRR 8.

Aksu v Turkey (2013) 56 EHRR 4.

Konstantin Markin v Russia (2012) 56 EHRR 8 para 143.

This has been attempted elsewhere. See Alexandra Timmer, 'Toward an Anti-Stereotyping Approach for the European Court of Human Rights' (2011) 11 HRLR 707; and Alexandra Timmer, 'Judging Stereotypes: What the European Court of Human Rights Can Borrow from American and Canadian Equal Protection Law' (2015) 63 AJCL 239. 
between pervasive gender stereotyping and VAW. The issue remains surprisingly under-examined in the ECtHR literature, however.

This chapter argues that the Court should address gender stereotyping in domestic violence cases and in that respect follow international human rights law. That is not to say that we think the Strasbourg Court can eliminate gender stereotypes. We think of the Court as one actor in a larger effort directed against the harmful gender stereotypes underpinning domestic violence. This effort is organised on many fronts, both legal and non-legal (such as via media, education and politics). Yet the only way the Court can play its role, this chapter further argues, is by carefully crafting legal reasoning that names and contests stereotypes. In naming gender stereotypes, the Court will be addressing one of the factors that structurally contributes to domestic violence and ineffective state responses. Naming gender stereotypes will thus enable the Court to frame the cases as gender-based rather than treating them as instances of individual and accidental violence. In contesting gender stereotyping, in turn, the Court will be demanding states to combat gender stereotyping and prohibiting them from relying on gender stereotypes to justify their unresponsiveness to violence.

Below, the chapter proceeds as follows. In the first part, we discuss the concept of stereotypes in general and that of gender stereotypes more specifically. In this part, we additionally outline the developments in international human rights law recognising the role that gender stereotypes play in violence against women and calling on states to combat them. In the second part, we name the gender stereotypes underlying various domestic violence cases in the Strasbourg case law and suggest ways in which the Court can contest them.

\section{THE CONCEPTUAL AND LEGAL FRAMEWORK}

\subsection{ON STEREOTYPES}

In this chapter, we conceive of stereotypes as 'beliefs about groups of people'. This is a fairly minimal and neutral definition, ${ }^{5}$ which leaves room for the fact that stereotypes come in various forms. Stereotypes can be prescriptive: prescribing a certain kind of behaviour or standard of appearance to (sub)groups of people (eg women should be slim/men should be muscular; women should be submissive/men should lead). They can also be descriptive: these stereotypes describe a statistical truth about a group as a whole, but do not necessarily accurately reflect the situation of the individual. In other words, descriptive

Other definitions, notably the one of Cook and Cusack, are more elaborate. $C f$ the definition of a stereotype of Rebecca Cook and Simone Cusack: 'a generalized view or preconception of attributes or characteristics possessed by, or the roles that should be performed by, members of a particular group'. Rebecca Cook and Simone Cusack, Gender Stereotyping: Transnational Legal Perspectives (University of Pennsylvania Press 2010) 9. 
stereotypes are largely accurate but overbroad assumptions (eg women live longer). Then there are also false stereotypes: false stereotypes are either based on prejudice or they simply have an unsound empirical/statistical basis (eg women are weak). And finally there are role-typing stereotypes: these are assumptions about the proper roles or modes of behaviour of people who belong to a certain group (famously eg women are homemakers/men are breadwinners). ${ }^{6}$ One stereotype can fall under multiple of these headers (eg 'women are homemakers' has both a descriptive and a prescriptive dimension; and is also a role-type). As Rikki Holtmaat has pointed out, 'the line between descriptive and prescriptive stereotypes is very thin since many descriptions of what women are, also function as prescriptions of how they should behave. ${ }^{7}$ What is more, not only do stereotypes appear in these various forms, our neutral definition also leaves room for the fact that they can be both positive (eg 'women are caring') and negative (eg 'women are weak').

In the first place, stereotypes are held at the individual level. All of us harbour stereotypes, and these can be triggered automatically when we come into contact with members of the stereotyped group. This plays out at an unconscious level, without awareness or intention. ${ }^{8}$ Important for present purposes is that stereotypes also have a collective dimension: 'many (perhaps most) of our stereotypes are in fact widely held and culturally sanctioned'. ${ }^{9}$ In this sense stereotypes are social norms; the extent to which people hold and express stereotypes depends on what they deem fit within their social environment. ${ }^{10}$ The fact that stereotypes become social norms is what makes them so dangerous, as we will show below when we discuss states' lack of response to domestic violence cases.

Stereotypes attribute (perceived) group characteristics to the individual, without regard to the individual's actual situation. In this way, stereotyping can result in different kinds of harms. It has been argued that people feel the injurious effects in the realms of (social) recognition, (material) distribution, and individual psychological well-being. ${ }^{11}$ We note that all forms of stereotypes discussed above can have harmful effects, including so-called positive stereotypes. Salient examples are the many benevolent yet patronising stereotypes about women: when women are held to be nurturing, warm and caring, this serves to justify

This typology draws on Timmer (2015) (n 4) 255-259.

Rikki Holtmaat, 'Article 5' in Marsha A Freeman, Christine Chinkin and Beate Rudolf (eds), The UN Convention on the Elimination of All Forms of Discrimination Against Women. A Commentary (OUP 2011) 141-67.

$8 \quad$ See eg Patricia G Devine and Lindsay B Sharp, 'Automaticity and Control in Stereotyping and Prejudice' in Todd D Nelson (ed), Handbook of Prejudice, Stereotyping and Discrimination (Psychology Press 2009) 62; and Anthony G Greenwald and Mahzarin R Banaji, 'Implicit Social Cognition: Attitudes, Self-Esteem, and Stereotypes' (1995) 102 Psychol Rev 4.

$9 \quad$ David J Schneider, The Psychology of Stereotyping (Guilford Press 2004) 322.

10 Charles Stangor, 'The Study of Stereotyping, Prejudice and Discrimination within Social Psychology: A Quick History of Theory and Research' in Todd D Nelson (ed), Handbook of Prejudice, Stereotyping and Discrimination (Psychology Press 2009) 1, 4.

11 Timmer (2011) (n 4) 715-716. 
a system of patriarchy where men perform the leading roles and women the supportive ones.

So far, we have discussed the concept of stereotype in general. We turn now to gender stereotypes more specifically. Rebecca Cook and Simone Cusack describe gender stereotypes as 'beliefs about the personal attributes of women and men'. ${ }^{12}$ Offering a definition of gender stereotypes is difficult, as the concept of gender is itself fluid and contested. Cook and Cusack have, however, developed a useful four-pronged typology of gender stereotypes. ${ }^{13}$ First are sex stereotypes; these concern 'the physical and biological differences between men and women'. ${ }^{14} \mathrm{Next}$ are sexual stereotypes, meaning those stereotypes which focus 'on the sexual interaction between men and women'. ${ }^{15}$ Third are sex role stereotypes, these ascribe certain roles and behaviour to men and women. And lastly Cook and Cusack distinguish compounded stereotypes; meaning gender stereotypes that interact with other stereotypes to produce specific beliefs about sub-groups of men and women. Below, we will see some of these four forms of gender stereotypes reflected in the Strasbourg Court's case law on domestic violence. But first we will explore the legal framework that has been developed in international human rights law regarding violence against women.

\subsection{GENDER STEREOTYPES AS A ROOT CAUSE OF VIOLENCE AGAINST WOMEN IN INTERNATIONAL HUMAN RIGHTS LAW}

Following decades of scattered attention if not silence, ${ }^{16}$ violence against women entered international human rights law as a human rights issue in the 1990s. ${ }^{17}$ One significant development of these past few decades has been the recognition of the links between violence against women and the broader problem of gender inequality. The United Nations Convention on the Elimination of All Forms of Discrimination against Women (CEDAW) has considerably contributed to this development. Though CEDAW does not explicitly address violence against women, its monitoring Committee (CEDAW Committee or the Committee)

Cook and Cusack (n 5) 20.

Ibid 25-31.

Ibid 25 .

Ibid.

Dianne Otto, 'Lost in Translation: Re-scripting the Sexed Subjects of International Human Rights Law' in Anne Orford (ed), International Law and Its Others (CUP 2006) 333 (noting that the Universal Declaration of Human Rights left issues such as gendered violence silent).

17 Rhonda Copelon, 'International Human Rights Dimensions of Intimate Violence: Another Strand in the Dialectic of Feminist Lawmaking' (2003) 11 Journal of Gender, Social Policy and the Law 866 and Alice Edwards, Violence Against Women Under International Human Rights Law (CUP 2013) 7. For fuller accounts of the trajectory of violence against women in international human rights law see ibid 865-876 and 7-12, respectively. 
has long regarded such violence as a form of discrimination against women. ${ }^{18}$ According to the Committee, violence is 'gender-based' when it 'is directed against a woman because she is a woman' or when it 'affects women disproportionately'. ${ }^{19}$

One of the fundamental implications of characterising the problem as one of discrimination against women is that violence against women is no longer seen as the result of an isolated individual act but rather as part of a more systemic problem. ${ }^{20}$ This understanding invites the interrogation of the unequal power relations between men and women that many feminists view at the root of violence against women. ${ }^{21}$ More specifically, it invites human rights law to expose and address the structural causes of violence against women, ${ }^{22}$ including traditional stereotypes of men and women. ${ }^{23}$

Indeed, the CEDAW Committee's understanding of VAW as part of the wider problem of inequality has gone hand in hand with the Committee's recognition that gender-stereotyped roles are a root cause of such violence. The Committee has noted that 'traditional attitudes by which women are regarded as subordinate to men or as having stereotyped roles' perpetuate violence against women. ${ }^{24}$ It has said that these attitudes may justify such violence and that, in turn, the consequences of such violence may maintain women in subordinate roles. ${ }^{25}$ In fact, the Committee has found a violation of Article 5(a) - the CEDAW provision mandating states to combat gender stereotypes - in various cases concerning violence against women, including domestic violence ${ }^{26}$ and rape. ${ }^{27}$ For example, in A.T. $v$ Hungary, concerning domestic violence, the CEDAW Committee noted that the facts of the case revealed 'aspects of the relationships between the sexes and attitudes towards women' found in the country as a whole, namely the 'persistence of entrenched traditional stereotypes regarding the role and responsibilities of women and men in the family. ${ }^{28}$

18 General Recommendation No 19, Violence against Women (1992) paras 1, 6 and 7. See also Yildirim v Austria (6/2005), CEDAW/C/39/D/6/2005 (2007) para 12.2 and V.K. v Bulgaria (20/2008), CEDAW/C/49/D/20/2008 (2011) para 9.11.

19 General Recommendation No 19, Violence against Women (1992) para 6.

$20 \quad$ See eg Edwards (n 17) 186.

${ }_{21}$ See generally Elizabeth M Schneider, Battered Women and Feminist Lawmaking (Yale University Press 2000). 'Feminist legal arguments about gender violence have developed from feminist insights about the way heterosexual intimate violence is part of a larger system of coercive control and subordination; this system is based on structural gender inequality and has political roots': ibid 5.

22 Edwards (n 17) 186 (regarding this as one of the advantages of framing the problem as one of sex discrimination and inequality).

Ibid 189.

General Recommendation No 19, Violence against Women (1992) para 11.

Ibid.

A.T. $v$ Hungary (2/2003), CEDAW/C/32/D/2/2003 (2005).

Karen Tayag Vertido $v$ The Philippines (18/2008), CEDAW/C/46/D/18/2008 (2010).

A.T. $v$ Hungary (2/2003), CEDAW/C/32/D/2/2003 (2005), para 9.4. The CEDAW Committee has linked gender stereotypes to various forms of structural subordination of women, including violence against women. See Rikki Holtmaat, 'Preventing Violence against Women: The Due Diligence Standard with Respect to the Obligation to Banish Gender Stereotypes on 
Human rights instruments specifically addressing violence against women locate such violence similarly within the larger framework of gender inequality. For instance, the Council of Europe Convention on Preventing and Combating Violence against Women and Domestic Violence (Istanbul Convention) views gender inequality as the cause and consequence of violence against women. ${ }^{29}$ Particularly telling is the fact that one of the purposes of the Istanbul Convention is to 'contribute to the elimination of all forms of discrimination against women and promote substantive equality between women and men'. ${ }^{30}$ Like the CEDAW Committee, the Istanbul Convention conceptualises violence against women as a form of discrimination against women, ${ }^{31}$ although it does so ambiguously when it comes to domestic violence. ${ }^{32}$ On one side, it sets domestic violence apart from other forms of violence against women. ${ }^{33}$ This is evidenced in the title of the Convention and in various provisions, including Article 3 defining violence against women but not domestic violence as gender-based. ${ }^{34}$ On the other side, the Istanbul Convention recognises that 'domestic violence affects women disproportionately ${ }^{35}$ and defines 'gender-based violence against women' precisely as including violence that affects women disproportionately. ${ }^{36}$ Thus, the Istanbul Convention suggests that domestic violence is not exclusively genderbased; it also affects other groups such as the elderly, children and men. ${ }^{37}$

the Grounds of Article 5(a) of the CEDAW Convention' in Carin Benninger-Budel (ed), Due Diligence and Its Application to Protect Women from Violence (Martinus Nijhoff 2008) 78.

29 See Council of Europe, 'Preventing Violence against Women: Article 12 of the Istanbul Convention, A Collection of Papers on the Council of Europe Convention on Preventing and Combating Violence against Women and Domestic Violence,' prepared by Marianne Hester and Sarah-Jane Lilley (September 2014) 6. The United Nations Declaration on the Elimination of Violence against Women (UN Declaration) also views violence against women as both a consequence and a cause of the subordinate status of women in society. Its Preamble does not just recognise that 'violence against women is a manifestation of historically unequal power relations between men and women.' It also states that 'violence against women is one of the crucial social mechanisms by which women are forced into a subordinate position compared with men.' See also the Preamble of the Inter-American Convention on the Prevention, Punishment, and Eradication of Violence against Women (Convention of Belém do Pará) recognising that violence against women is 'a manifestation of the historically unequal power relations between women and men.'

30 Article 1(b) of Council of Europe Convention on Preventing and Combating Violence against Women and Domestic Violence (Istanbul Convention).

$31 \quad$ Article 3(a) of Istanbul Convention.

32 Römkens notes and critiques this ambiguity. Renée G Römkens, 'Reflections on Domestic Violence as Gender-Based Violence in European Legal Developments' in M Mohamad and S Wieringa (eds), Family Ambiguity and Domestic Violence in Asia. Concepts, Law, and Process (Sussex Academic Press 2013) 92-209.

33 Ibid 203.

34 Article 3(a) and (b) of Istanbul Convention. Römkens (n 32) 201-202.

35 Preamble and Article 2 of Istanbul Convention.

36 Article 3(d) of Istanbul Convention: “gender-based violence against women” shall mean violence that is directed against a woman because she is a woman or that affects women disproportionately' (emphasis added).

37 Römkens (n 32) 202 (noting that the Explanatory Report makes it clear that the Istanbul Convention intends to include children, men and the elderly). She argues however that it is 
Be that as it may, what is most relevant for present purposes is that the Istanbul Convention similarly links gender-based violence against women to gender stereotypes. Gender-based violence against women is viewed as 'both the cause and the result of unequal power relations based on perceived differences between women and men'. ${ }^{38}$ More precisely, the expression of gender-based violence is understood 'as aimed at protecting women from violence resulting from gender stereotypes'. ${ }^{39}$

Following the understanding of the problem as one of gender inequality linked to gender stereotypes, a certain set of solutions has emerged in international human rights law. These solutions do not simply require states to address the consequences of gender-based violence but also its root causes. ${ }^{40}$ In tackling violence against women, the CEDAW Committee for example has been concerned with a notion of gender equality that attends to broader and structural inequality and that aims at social transformation by, inter alia, combating the spread of stereotypes. ${ }^{41}$ This approach is reflected in the recommendations that the Committee has adopted in some of the above-mentioned VAW case law involving violations of Article 5(a) of CEDAW. ${ }^{42}$ More foundationally, it is embodied in the CEDAW drafters' awareness that 'a change in the traditional role of men as well as the role of women in society and in the family is needed to achieve full equality between men and women'. ${ }^{43}$

The Istanbul Convention, in turn, calls for gender-based violence against women to be addressed within the context of 'the prevailing inequality between women and men, existing stereotypes, gender roles and discrimination against women in order to adequately respond to the complexity of the phenomenon'. ${ }^{4}$ Echoing provisions of CEDAW, ${ }^{45}$ the Istanbul Convention requires State Parties

'internally contradictory' and inconsistent with the standards set by international human rights law, notably CEDAW, 'to position domestic violence against men within its realm.' ibid.

38 Istanbul Convention, Explanatory Report, 12 April 2011, para 44.

39 Ibid.

40 See Julie Goldscheid, 'Domestic and Sexual Violence as Sex Discrimination: Comparing American and International Approaches' (2006) 28 Thomas Jefferson L Rev 386-387.

${ }_{41}$ Sally Engle Merry, 'Battered Women and Feminist Law Making: Author Meets Readers Elizabeth M. Schneider, Christine Harrington, Sally Engle Merry, Renée Römkens and Marianne Wesson' (2001-2002) 10 JLP 362. See also Edwards (n 17) 193 (arguing that the responses of international human rights law treaty bodies have included 'recommendations for social and cultural change').

42 See eg Karen Tayag Vertido $v$ The Philippines (18/2008), CEDAW/C/46/D/18/2008 (2010) para 8.9(b).

43 Preamble of the United Nations Convention on the Elimination of All Forms of Discrimination against Women (CEDAW).

$44 \quad$ Istanbul Convention, Explanatory Report, 12 April, 2011, para 43.

45 Article 5 of CEDAW. See also Article 4(j) of the UN Declaration, which similarly asks states to adopt all appropriate measures to eliminate prejudices and practices 'based on the idea of the inferiority or superiority of either of the sexes and on stereotyped roles for men and women.' A similar obligation is contained in Article 8(b) of the Convention of Belém do Pará, which importantly adds that customs, prejudices and practices based on such stereotyped roles 'legitimize or exacerbate violence against women'. 
to promote changes in attitudes towards women as well as towards their role and status in society. ${ }^{46}$ In the words of the drafters:

All measures to prevent violence against women should ... be framed in the context of the promotion and the practical realisation of equality between women and men through eliminating discrimination against women, changing patriarchal attitudes and fighting back gender stereotypes. ${ }^{47}$

It is therefore clear from the developments in international human rights law that the eradication of gender-based violence against women cannot be achieved without tackling the gender stereotypes at the root of gender inequality. To a large extent, international human rights law has incorporated the feminist insight that violence against women both expresses and reproduces unequal gender relations based on stereotyped roles. Feminists have long been concerned with the use of gender stereotypes to justify and perpetuate women's subordinate status in society, ${ }^{48}$ of which violence is one more manifestation. ${ }^{49}$ Rikki Holtmaat argues that the root causes of gender-based violence lie in norms and practices that view women as unequal or inferior to men and that often reflect gender stereotypes. ${ }^{50}$ These stereotypes send strong messages about men's and women's roles in society and about their 'proper behaviour'. ${ }^{51}$ Feminists have viewed domestic violence, for instance, as 'a means to control the behaviour of [the batterer's] victim so that she conforms to his expectations and societal expectations of the "true woman". ${ }^{52}$ Christine Littleton vividly explains the operation of these stereotypes: 'If only she had been a better wife, a more submissive helpmate, a more compliant sexual partner, then her nose would not have been broken, her eye would still be uncut, the bruises would never have marked her thighs. ${ }^{53}$

46 Article 12 of Istanbul Convention. See Hester and Lilley (n 29) 7.

47 Ad Hoc Committee on Preventing and Combating Violence against Women and Domestic Violence (CAHVIO), Interim Report, 27 May 2009, CAHVIO (2009) 4 FIN, para 17. As Hester and Lilley note: 'The ultimate aim is to change the behaviour of men and women, boys and girls, that is currently all too often influenced by prejudice, gender stereotypes or genderbiased customs and traditions, and that helps to perpetrate or condone violence against women'. Hester and Lilley (n 29) 7.

48 See eg Neil S Siegel and Reva B Siegel, 'Struck by Stereotype: Ruth Bader Ginsburg on Pregnancy Discrimination as Sex Discrimination' (2010) 59 Duke LJ 771-798.

49 Many feminists view violence against women as 'a facet of women's subordination in society.' Schneider (n 21) 59. See also Melanie Randall, 'Domestic Violence and the Construction of "Ideal Victims": Assaulted Women's “Image Problems" in Law' (2004) 23 St L U Pub L Rev 111-112: 'Gendered violence is a phenomenon that emerges from and reinforces women's subordinate status in society.'

$50 \quad$ Holtmaat (n 28) 63.

51 Ibid.

52 Zanita E Fenton, 'Domestic Violence in Black and White: Racialized Gender Stereotypes in Gender Violence' (1998-1999) 8 Col J Gender L 18.

53 Christine A Littleton, 'Women's Experience and the Problem of Transition: Perspectives on Male Battering of Women' (1989) 23 University of Chicago Legal Forum 29, quoted by Fenton in ibid $27-28$. 
Notwithstanding its advances, the formulation of violence against women as rooted in gender inequality remains fraught with difficulties and complexities. ${ }^{54}$ Some of these difficulties are conceptual. Equality and non-discrimination are contested concepts. ${ }^{55}$ Equality, for example, may be understood as narrowly aiming to treat likes alike - in this case, to treat men and women identically (formal equality). ${ }^{56}$ Or it may be conceptualised as more substantively concerned with tackling gender disadvantage, oppression and subordination. ${ }^{57}$ Pinning down the exact links between violence against women, inequality between men and women, gender subordination, discrimination against women and gender stereotypes largely depends on the interpretation of these concepts. A substantive conception of equality is better able to encompass the idea that violence is also an inequality issue. So far, however, international human rights law continues to struggle with the meanings of non-discrimination and equality, despite some shifts towards substantive equality.$^{58}$ In fact, it appears that settling the meaning of these concepts 'remains one of the greatest challenges for international human rights law'. ${ }^{59}$

International human rights law's framing of VAW as a form discrimination against women has arguably been accompanied by another set of concerns. These concerns flow from the emphasis placed on women as victims of violence, ${ }^{60}$ which in turn has been part of the broader strategy to have gender-specific rights acknowledged as human rights. ${ }^{61}$ The VAW model's focus on women's victimhood has been double-edged. On the one hand, the gender-specific frame of VAW has emphasised the harms of violence historically experienced by women and its roots in sex discrimination and female subordination. ${ }^{62}$ On the other hand, the emphasis on the gender identity of the victim has fostered disempowering portrayals of women.

Thus, whereas anti-stereotyping concerns are at the heart of feminist critiques of VAW, ironically the resulting laws have to some extent resulted in more stereotyping. ${ }^{63}$ That is to say, the focus on women as victims of violence has

$54 \quad$ Edwards (n 17) 190-197.

$55 \quad$ Ibid 142.

56 This is the sameness/difference paradigm. As Alice Edwards explains: 'Inequality under this paradigm is when women are not treated the same as men; special treatment is allowed only as far as it will lead to their eventual identical position as men'. ibid 175.

57 Ibid 144-148 (referring in these terms to the understandings of equality advanced by Kathleen Mahoney, Iris Marion Young and Catharine MacKinnon, respectively).

$58 \quad$ Ibid.

$59 \quad$ Edwards (n 17) 196.

60 For fuller accounts of the concerns raised by the gender-specific frame of violence within international law see Dianne Otto, 'The Exile of Inclusion: Reflections on Gender Issues in International Law Over the Last Decade’ (2009) 10 Melb JIL 11-26. We focus only on those concerns relevant for the purposes of this chapter.

61 Otto (n 16) 345.

62 Julie Goldscheid, 'Gender Neutrality, the "Violence Against Women” Frame and Transformative Reform’ (2013-2014) 82 U Miss-K City L Rev 628.

63 Ibid 640-641. 
tragically perpetuated older stereotypes of women as powerless and inherently vulnerable in need of protection. ${ }^{64}$ As a result, the strategy has in many instances spurred on protective and even imperialist responses aimed at rescuing ('other') women. ${ }^{65}$ These responses have been critiqued for obscuring women's agency and resistance in the face of violence. ${ }^{66}$ More fundamentally, they have been questioned for treating the woman as a 'victim subject' rather than as a full subject of international human rights law. ${ }^{67}$ In treating women as the victims of violence, the gender-specific frame of VAW has been further critiqued for erasing analogous gendered injuries of violence suffered by other categories, including men. ${ }^{68}$ It has also been challenged for obfuscating the role of other factors such as race and age, a longstanding concern of intersectionality theorists. ${ }^{69}$

Given these and the other concerns discussed above, one critical question raised by feminists is the following: How to address the root causes of gendered violence without reinstating protective narratives of vulnerable women that undermine the feminist goals of women's emancipation and erase the experience of violence suffered by other categories of people? ${ }^{70}$

In the remaining parts we will focus on one specific form of violence, namely domestic violence. We will show how, in addressing gender stereotypes, the Court can direct attention to the root causes of domestic violence. In focusing on gender stereotypes rather than on the victim's gender identity, the Court may additionally circumvent re-inscribing the problem as one that concerns women alone and reinforcing images of women as archetypical victims.

\section{NAMING AND CONTESTING GENDER STEREOTYPES IN DOMESTIC VIOLENCE CASE LAW}

\subsection{NAMING GENDER STEREOTYPES AND EXPOSING THEIR HARMS}

Efforts aimed at eliminating wrongful gender stereotypes have to begin with naming these stereotypes and the ways in which they harm women. ${ }^{71}$ As Rebecca Cook and Simone Cusack argue: 'Unless wrongful gender stereotyping is diagnosed as a social harm, it will not be possible to determine its treatment

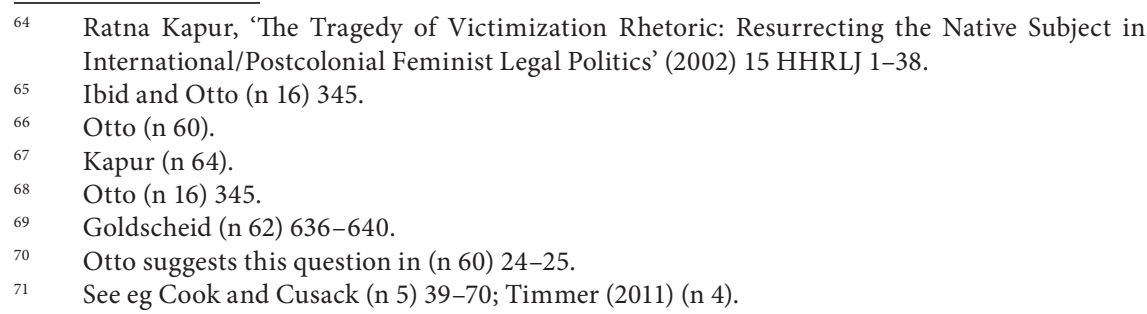


and bring about its elimination'. ${ }^{72}$ The task of naming harmful stereotyping can sometimes be challenging, as it usually involves making visible what is socially deeply ingrained as 'natural' or 'normal'.73 In the context of violence against women, it has been said that '[a] big difficulty for the attention and prevention of violence against women is that it appears as culturally naturalized, as an intrinsic characteristic of social relations and accepted gender model'. ${ }^{74}$

In this part, we name the gender stereotypes operative in two stages of the domestic violence cases: (1) the gender stereotypes underlying or causing the violent incidents; and (2) the gender stereotypes guiding or impacting the state responses to domestic violence. In addition, we explain how these stereotypes hurt the applicants or their female relatives affected by violence.

In many of the cases discussed below, gender stereotypes are often implicit. In other words, to a large extent, they operate subtly rather than overtly. The absence of explicit stereotypical remarks on record makes it challenging to uncover implicit stereotyping. Most of the cases we examine reveal stereotypical views of female victims of domestic violence. These are general assumptions about 'ideal' behaviours and 'proper' roles that female victims (ought to) display and perform in the face of violence. As will become evident in the discussion that follows, the stereotypes surrounding victimhood are in turn infused by gender stereotypes. The majority of them are sex-role stereotypes. These stereotypes feature in the state responses examined below, either at the domestic level or at the supranational level (ie in states' submissions to the Strasbourg Court).

\subsubsection{Women are (or Ought to be) Weak, Passive and Helpless}

One gender stereotype implicit in state responses to domestic violence cases is the negative sex role stereotype that women are - or ought to be - weak, passive and helpless in the face of violence. This stereotype is for instance at play in Kalucza $v$ Hungary - a case concerning allegations of assault, harassment and rape by a former common-law husband. ${ }^{75}$ The domestic courts' rejections of the applicant's requests for restraining orders were largely motivated by the fact that the applicant had also been violent towards her former husband. The District Court, for instance, rejected the applicant's first request, after establishing that 'the bad relationship which has developed between the parties can be imputed

\footnotetext{
Cook and Cusack (n 5) 40.

Ibid 41.

Ibid 41-42.

Kalucza v Hungary App no 57693/10 (ECtHR, 24 April 2012). See also ECtHR, Bevacqua and S. $v$ Bulgaria App no 71127/01 (ECtHR, 12 June 2008) paras 61-62. In this case, the state's submissions before the Strasbourg Court underestimated the violence exerted on the applicant by her husband by framing the case as one of 'querulous allegations exchanged between spouses in the course of divorce proceedings.' ibid para. 61. In this way, the blame was thus partly placed on the applicant and the violence she experienced made invisible.
} 
to both parties' ${ }^{76}$ Yet more illustrative is the reasoning of the Regional Court upholding the dismissal of her second request: 'the ordering of a coercive measure only in respect of one party - in the present case against Gy.B. - is not justified due to the involvement of the aggrieved party. ${ }^{77}$

In being violent towards her former husband, the applicant in Kalucza deviates from stereotypical views of domestic violence victims. If a woman fights back, she is 'too strong.' ${ }^{78}$ The 'ideal' or 'real' victim of domestic violence is the opposite. ${ }^{79}$ Stereotypically, she is one who does not use violence against her violent partner. The use of violence therefore undermines her status as a victim. ${ }^{80}$ Referring to women who use violence, Leigh Goodmark explains: 'These women must also overcome the stereotype that they defy: the weak, passive, and helpless battered woman'. ${ }^{81}$ This stereotypical view of domestic violence victims is in turn infused by the gender stereotype of 'feminine passivity and tolerance'. ${ }^{82}$ Women resisting domestic violence with violence thus find their credibility challenged both as a woman and as a woman alleging violence. ${ }^{83}$

This was certainly the case in Kalucza. Once the domestic judges learned that the applicant had used violence herself, her victim status and her ensuing ability to secure a restraining order were undermined. In fact, this was the main reason to dismiss her request for restraining orders against her husband. The mix of victimisation and sex role stereotypes at the root of the state inaction therefore harmed the applicant very concretely: she was deprived from protection against further violence. According to Rebecca Cook and Simone Cusack, one of the ways in which gender stereotypes harm women is by imposing a burden on them. ${ }^{84} \mathrm{~A}$ gender stereotype, they note, may burden women by making them vulnerable to (more) violence. ${ }^{85}$ They may also harm them by 'reducing the likelihood that sexual assault perpetrators would be held legally accountable, and so deterred'. ${ }^{86}$ An illustration of the latter form of harm is the discontinuation of the investigations by the District Prosecutor's Office in Kalucza. The Prosecutor's reasoning evokes the stereotypes animating the courts' dismissal of the requests for restraining orders against the former husband. Indeed, the Prosecutor

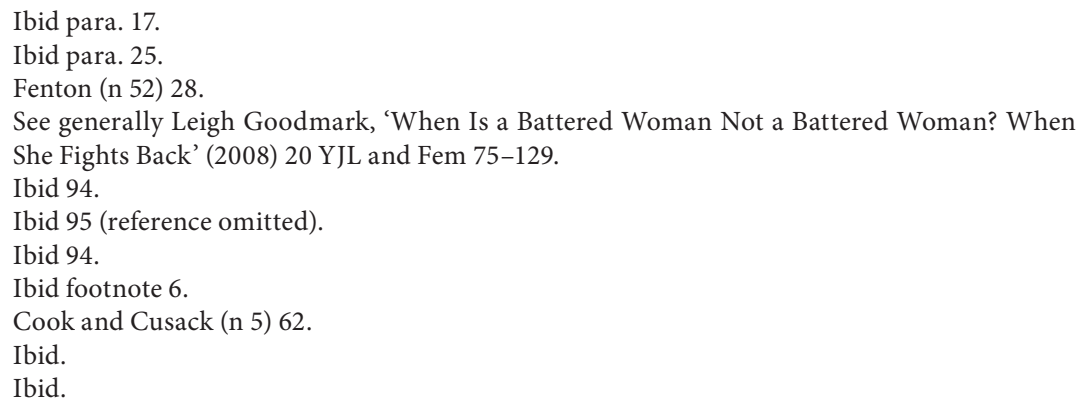


discontinued the investigation against the applicant's former husband for alleged sexual harassment after finding that animosity was reciprocal. ${ }^{87}$

The Strasbourg Court is mindful that one of the main reasons for refusing to protect the applicant was the fact that the woman was violent herself. It states that the domestic authorities 'had a positive obligation to protect the applicant from the violent behaviour of her former common-law husband exerted in her home, notwithstanding the fact that she had also been violent towards him' ${ }^{88}$ The Court does not only note that the domestic authorities did not give much reason to deny the restraining orders other than saying that 'the bad relationship was imputable to both parties' ${ }^{89}$ The Court also adds:

[I]f it could not be ordered in cases of mutual assaults, then the aim of providing effective protection to victims would be seriously undermined. The possibility that the victim acted in legitimate self-defence cannot be ruled out at that stage ... The domestic court's reasoning that a restraining order could not be issued in view of the aggrieved party's involvement is therefore not acceptable. ${ }^{90}$

The Court firmly establishes that the positive obligation to protect the applicant subsisted and that the reciprocal character of the assaults could not in any way undermine, let alone eliminate, this obligation. Moreover, in highlighting the possibility of self-defence, the Court implicitly underscores the applicant's resistance and agency. It thus avoids re-enacting the stereotypes of victims' passiveness underpinning the domestic courts' responses. Yet the Court does not go as far as naming the stereotype influencing the state's inaction: that female victims of domestic violence (should) endure violence passively and helplessly. The stereotype in question is rather prescriptive because it expects women to remain passive when confronted with violence. At the same time, it is false because it assumes that women are weak and helpless without sound empirical basis.

\subsubsection{Women Ought to be Submissive}

Another stereotype usually associated with domestic violence also implicit in state responses is the stereotype that 'the victim precipitates her own assault'. ${ }^{1}$ This stereotype, in turn, suggests the normative gender stereotype that women should not provoke men. In other words, they ought to be submissive or obedient to men, including their male partners. The stereotypes in question underpin

\footnotetext{
87 Kalucza v Hungary App no 57693/10 (ECtHR, 24 April 2012), para 19: 'The Prosecutor's Office established that there was animosity between the parties and that the applicant's allegations alone were not sufficient to prove the commission of any crime'.

88 Ibid para 61 (emphasis added).

$89 \quad$ Ibid para 65.

$90 \quad$ Ibid para 66.

$91 \quad$ Fenton (n 52) 27.
} 
state responses highlighting women's 'provocation' of violence, a notion that feminists have challenged for its male bias. ${ }^{92}$ Laws on provocation, some feminists have shown, have largely been shaped by 'male rhymes, reasons and excuses.93 Examples of the implicit normative stereotype that women ought to be submissive include E.M. $v$ Romania, concerning allegations of physical aggression and threat by the husband, ${ }^{94}$ and B. $v$ the Republic of Moldova, also involving violence by a husband..$^{95}$

In E.M. $v$ Romania, the implicit stereotype plays a role, along with other factors, in determining the sanction applied in a proceeding for assault and injuries caused by the applicant's husband to her mother. The domestic court considered that an administrative sanction was enough, given the 'real circumstances' within which the facts occurred, including that they had been triggered and prolonged by the applicant's mother. ${ }^{96}$ It is not clear how exactly the victim triggered and extended the violent behaviour.

Regardless of the nature of the provocation, this type of reasoning is problematic for various reasons. It locates the source of the problem in the victim - she triggered the violent 'reaction' - while directing attention away from the violent behaviour of the perpetrator. This does not only justify such behaviour toward the woman; it actually puts the blame on her. Moreover, this sort of reasoning stereotypically assumes that, in the face of provocation, the man cannot hold himself but only react violently in a state of rage. ${ }^{97}$ In E.M. these implicit stereotypical assumptions about both female and male behaviours harms the woman in quite concrete terms: the person responsible for the violence gets a more lenient sanction.

In B. $v$ the Republic of Moldova, in turn, the courts adopted six administrative decisions, following the applicant's allegations of beatings by her husband. Four of these decisions fined the husband and one of them noted that the applicant had

92 See Clare Connelly, 'Attorney-General for Jersey v Holley: Commentary' in Rosemary Hunter, Clare McGlynn and Erika Rackley (eds), Feminists Judgments: From Theory to Practice (Hart Publishing 2010) 292-96. The law on provocation in the United Kingdom, for example, has been challenged for its 'masculine bias in favour of those who react to provoking events with anger - classically in the case of men who discover that their wives have committed adultery and/or are planning to leave them - as opposed to abused women who react through terror and despair, often in response to years of abuse rather than a single provoking event.' ibid 292.

93 Susan Edwards, 'Attorney-General for Jersey v Holley: Judgment' in Rosemary Hunter, Clare McGlynn and Erika Rackley (eds), Feminist Judgments: From Theory to Practice (Hart Publishing 2010) 301.

$94 \quad$ E.M. $v$ Romania App no 43994/05 (ECtHR, 30 October 2012).

$95 \quad$ B. $v$ the Republic of Moldova App no 61382/09 (ECtHR, 16 July 2013).

96 E.M. v Romania App no 43994/05 (ECtHR, 30 October 2012), para 40: 'Prenant en compte les " circonstances réelles » dans lesquelles les faits s'étaient produits, à savoir qu’ils auraient été déclenchés et prolongés par M.V., l'absence d'antécédents pénaux d'I.B. et son attitude sincère, le parquet estima qu'une amende administrative était une sanction suffisante.' The other two factors are thus the lack of criminal record and the sincere attitude of I.B. Edwards (n 93) 301. 
'provoked him', although it is not clear how. ${ }^{98}$ The fines ranged from the equivalent of 8.65 to 18 euros. ${ }^{99}$ The idea that the applicant provoked her husband resurfaces in the Supreme Court's decision rejecting the applicant's request for eviction of her husband from their common apartment to escape further violence. ${ }^{100}$ The applicant's request relied on her husband's violent behaviour. ${ }^{101}$ The Supreme Court rejected the claim for eviction with the argument that the evidence was insufficient to prove the husband's systematic violent behaviour. ${ }^{102}$ This was despite the above-mentioned cases that resulted in sanctions against him. In fact, the Supreme Court noted that in one of those decisions 'it had been mentioned that the applicant herself had provoked V.B.'s violence'. ${ }^{103}$

Admittedly, it is difficult to establish the links between the stereotype implicit in the idea that the applicant provoked her husband's violence and the small fines ordered by the courts or the Supreme Court's reluctance to issue an eviction order. The example serves nonetheless to show the existence of a victim-blaming mentality based on the idea that the women 'asked for' for the abuse. ${ }^{104}$ As we have noted above, the problem with victim-blaming mentality is that it contributes to violence becoming less visible. ${ }^{105}$ In $B$. the Supreme Court certainly fails to 'see' the husband's violent behaviour by simply noting that the applicant herself provoked him.

The Strasbourg Court critiques that the subsequent courts' decisions kept referring back to the Supreme Court's ruling without any consideration of the further acts of violence against the applicant. ${ }^{106}$ One of the Strasbourg Court's conclusions is that the domestic authorities effectively forced the applicant 'to continue risking being subjected to violence or to leave home'. ${ }^{107}$ However, there is no word on whether the problematic decisions were grounded in gender stereotypes implicit in misconceptions about domestic violence victims, let alone on whether such misconceptions played a role in the decisions.

\footnotetext{
$98 \quad$ B. $v$ the Republic of Moldova App no 61382/09 (ECtHR, 16 July 2013), para 9. The other two decisions terminated the proceedings following a friendly settlement and the expiry of the limitation period, respectively.

Ibid.

Ibid para 14 .

Ibid para 11 .

Ibid para 14.

Ibid.

Fenton (n 52) 27.

Martha R Mahoney, 'Legal Images of Battered Women' (1991) 90 Mich L Rev 27.

B. $v$ the Republic of Moldova App no 61382/09 (ECtHR, 16 July 2013) paras 56 and 74.

Ibid para 75 .
} 


\subsubsection{Women (Ought to) Endure Men's Aggressiveness or Violence (and Other Gender Stereotypes)}

One more example of how gender stereotypes may impact state responses to domestic violence is Eremia $v$ the Republic of Moldova. ${ }^{108}$ The case concerned allegations of repeated assaults on the first applicant by her husband, 'A.', in front of their daughters (second and third applicants). ${ }^{109}$ Though a protection order was made, the husband managed to breach it recurrently and to further assault the applicant on several occasions. ${ }^{110}$ The protection order was ultimately partly revoked on appeal. ${ }^{111}$ A criminal investigation was opened following the applicant's request. ${ }^{112}$ The prosecutor, however, suspended it for one year given that the husband had committed a "less serious offence," did not abuse drugs or alcohol, had three minors to support, was well respected at work and in the community and "did not represent a danger to society." 113

Two sets of gender stereotypes can be identified in the domestic authorities' responses. The first set involves the sex role stereotypes that suffering is an inevitable part of (married) women's life and that aggressiveness is in turn a normal attribute of (married) men. These stereotypes can be discerned in the social workers' alleged advice to the applicant. The social workers apparently advised her to reconcile with her husband arguing that she was 'neither the first nor the last woman to be beaten up by her husband'. ${ }^{114}$ Female suffering, and its flip side, male aggression, are thus assumed to be part of the 'normal' state of affairs of marital life. The former stereotype is in fact a prescriptive one because it implies that women ought to accept violence and suffering in marriage. The latter is a false gender stereotype given its unsound empirical/statistical basis: all (married) men are not aggressive or violent. The stereotypical attitudes held by the social workers impacted negatively on the applicant's protection: it took around four months for them to enforce the protection order issued by the courts. ${ }^{115}$

The second group of gender stereotypes can be found in the police's response to the applicant's complaints of violence against her husband. These stereotypes are evidenced by the remarks allegedly made by the police to pressure the applicant into withdrawing her complaints. The reason given by the police was apparently that 'if A. had a criminal record and lost his job, this would have a negative impact on their daughters' educational and career prospects'. ${ }^{116}$ These remarks contain

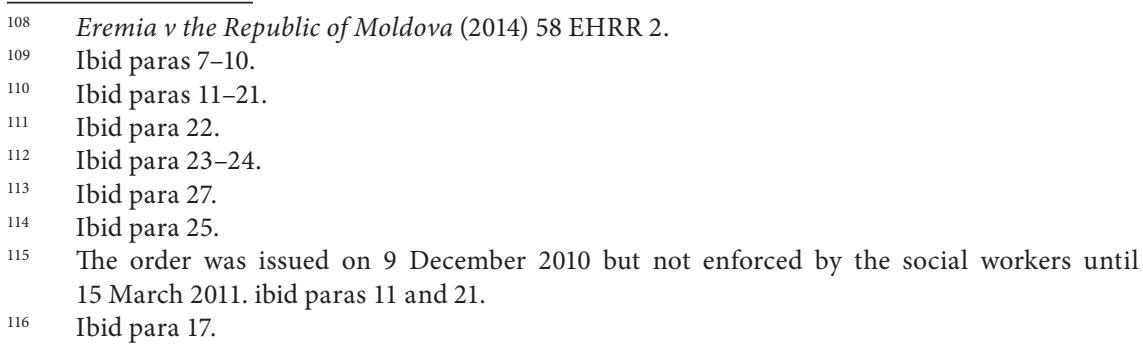


the sex role stereotype that men are breadwinners and, implicitly, the correlated stereotype that women are homemakers.

Indeed, the police fail to acknowledge that the mother may also have had a job to support their children's education and career. It appears that she actually had one. In claiming damages before the Strasbourg Court for the suffering caused to her, the applicant mentioned that she had been 'humiliated by her work colleagues ... for wanting to divorce A. and for "being a bad wife deserving to be beaten"'. ${ }^{117}$ The police's assumptions, however, suggest that the husband is the most important, if not the only, financial supporter in the house. The related assumption is that the wife's job is not as financially important or that she does not have one. The two stereotypical assumptions thus serve to reinforce a system of patriarchy where men play primary roles in the public sphere and women secondary ones in the private sphere. The prosecutor makes similar assumptions when it includes among the factors leading to the suspension of the investigation the fact that the husband 'had three minors to support' and that he was behaving as he ought in public: he 'was well respected at work and in the community and did not represent a danger to society'. ${ }^{118}$ The implicit gender stereotypes thus play a role first in discouraging the applicant from submitting a complaint and later on in suspending the criminal investigation against her husband for a year.

The Strasbourg Court finds a violation of Article 14 ECHR, read in conjunction with Article $3 \mathrm{ECHR}$, in respect of the applicant. In reaching this conclusion, the Court includes the pressure by the police and the delayed enforcement of the protection order by the social workers as factors reflecting a discriminatory attitude towards her as a woman. ${ }^{119}$ The Court shows particular concern with the way in which the social workers 'allegedly further insulted the applicant by suggesting reconciliation since she was anyway "not the first nor the last woman to be beaten up by her husband"' ${ }^{120}$ The Court however falls short of uncovering the gender stereotypes animating the pressure by the police and the suspension of the investigation by the prosecutor as well as the reluctance of the social workers to enforce the order to protect the applicant.

\subsubsection{Women are Financially Dependent}

Gender stereotypes may also appear in state's arguments before the Strasbourg Court. One illustration is Valiuliene $v$ Lithuania, concerning allegations of repeated acts of domestic violence. ${ }^{121}$ In disputing the idea that the applicant

\footnotetext{
$117 \quad$ Ibid para 95 (emphasis added).

$118 \quad$ Ibid para 27.

119 Ibid paras 87 and 89. The Court also found violations of Article 3 ECHR in respect of the first applicant and of Article 8 ECHR in respect of the second and third applicants.

$120 \quad$ Ibid para 87.

121 Valiuliené v Lithuania App no 33234/07 (ECtHR, 26 March 2013).
} 
could be considered a vulnerable person because of her age, gender or social status, the state argued:

[T] he applicant and J.H.L. had shared ownership of an apartment and, moreover, they had been business partners. The applicant thus had not been financially dependent on J.H.L.; she was an educated, independent woman who owned her own property. ${ }^{122}$

The problem with this sort of statement is that it perpetuates the myth that domestic violence does not happen to educated, property-owning and financially independent women. Put differently, the stereotypical view is that strong and independent women are not vulnerable to domestic violence. Embedded in this misconception is the sex role stereotyping that women vulnerable to domestic violence are those who are financially dependent and uneducated. The United Nations Special Rapporteur on Violence against Women has identified, albeit in another context, among the common misconceptions about violence against women the ideas that this 'is a phenomenon that takes place in poor and broken homes' and that 'victims of violence are inherently vulnerable women needing special protection'. ${ }^{123}$

These stereotypes seem to implicitly influence the state's reluctance to characterise the issue as one of ill-treatment within the meaning of Article 3 ECHR. Indeed, the argument quoted above was part of the state's efforts to exclude the treatment the applicant complained of from the scope of this ECHR provision. ${ }^{124}$ Moreover, the fact that the applicant did not fit the stereotypical image of domestic violence victims appears to be one of the elements that led the state to question whether the applicant's case was actually one of domestic violence. ${ }^{125}$ In short, in emphasising how the applicant falls short of stereotypical views of domestic violence female victims, the state attempts to impede the harms from becoming legally cognisable.

The Strasbourg Court rejects the state's argument about the triviality and non-continuing character of the physical aggression ${ }^{126}$ and concludes that the ill-treatment of the applicant 'was sufficiently serious to reach the level of

\footnotetext{
122 Ibid para 60.

123 United Nations Special Rapporteur on Violence against Women, Report on 2008 Visit to Moldova, referred to by the Court in Eremia $v$ the Republic of Moldova (2014) 58 EHRR 2, para 37.

124 Valiuliené $v$ Lithuania App no 33234/07 (ECtHR, 26 March 2013) paras 54-60. This contention was part of the broader argument that context in itself cannot necessarily attract the responsibility of the state and that, in any case, the situation of women in Lithuania was different from that of women in Turkey (referring to Opuzv Turkey). The other elements included the 'trivial nature' of the injuries and the non-premeditated and non-continuing character of the violence.

125 Ibid paras 54-62.

126 Ibid paras 64-68.
} 
severity under of Article 3 [sic]. ${ }^{127}$ Yet the Court does not take issue with the misconceptions informing the state's understanding of domestic violence. It does not unmask the gender stereotypes at the core of such misconceptions either.

\subsubsection{Women are Mothers and Homemakers (and Other Gender Stereotypes)}

One judgment illustrating how gender stereotypes can lay at the root of domestic violence is Opuzv Turkey. ${ }^{128}$ The case concerned violence against the applicant and her mother by a (former) husband. The husband had repeatedly assaulted them. He had stabbed the applicant seven times ${ }^{129}$ and attempted to run over the applicant and her mother. ${ }^{130}$ One of these assaults resulted in the mother's death. ${ }^{131}$

In the context of one of these multiple incidents, the husband asked the applicant upon her return home: 'Why are you wandering outside? Why haven't you cooked anything for me?'132 He continued: 'Why are you going to your mother so often? Don't go there so much, stay at home and look after the children!'133 These remarks, made before stabbing the applicant, remind us of the traditional division of labour between men and women on which sex role stereotypes are based. The first remark implicitly confines the applicant as a woman to the domestic sphere: she was not supposed to be 'wandering outside'. What follows is a series of other comments referring to the specific domestic tasks that the applicant should have devoted herself to: cooking and looking after their children. Both of them resonate with the well-known stereotypes based on gender roles that women should be 'homemakers' and 'caregivers'. One of them, 'why haven't you cooked anything for me', additionally contains stereotypes of female servitude, that is to say, that women are supposed to serve men.

Gender stereotypes also come into to play in the husband's motives for killing the applicant's mother. The husband stated these motives at the police, during the investigation against him for murder. He claimed that 'he had killed the applicant's mother because she had induced his wife to lead an immoral life'. ${ }^{134} \mathrm{He}$ further alleged that when he asked the deceased where his wife was, the deceased had replied 'F... off, I will take away your wife, and sell [her]'. ${ }^{135} \mathrm{He}$ added that 'he had lost his temper and had shot her for the sake of his honour and children'. ${ }^{136}$

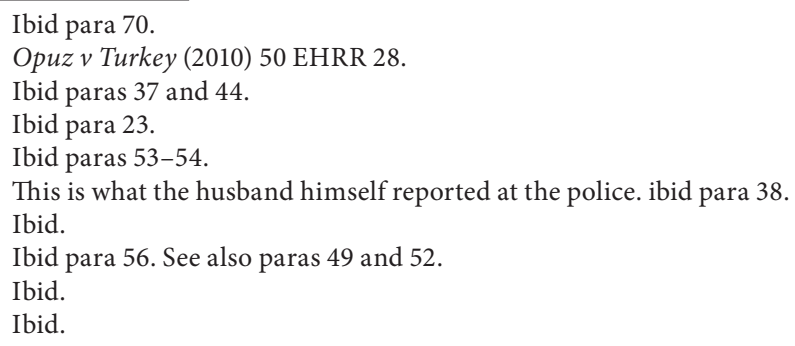


These statements signal stereotypical notions about 'proper' female sexual behaviour and the threat that women's nonconformity to such behaviour represents to the man's 'honour'. They embody sexual stereotypes, which condemn women but not men for what is socially viewed as licentious sexual behaviour. ${ }^{137}$ It has been argued that '[f]rameworks of "honour", and its corollary "shame", operate to control, direct and regulate women's sexuality and freedom of movement by male members of the family'. ${ }^{138}$ In fact, the applicant argued before the Strasbourg Court that the husband's alleged need to protect his honour had resulted in a lenient sentence. ${ }^{139}$

Opuz is not just an example of how gender stereotypes operate in causing violence. It also exemplifies the impact of gender stereotypes on state responses to domestic violence. One of these stereotypes is, once again, embedded in the idea of 'provocation'. The domestic courts reduced the sentence originally imposed on the applicant's husband for murdering her mother 'taking into account the fact that the accused had committed the offence as a result of provocation by the deceased and his good conduct during the trial'. ${ }^{40}$ The sentence thus changed from life imprisonment to fifteen years and ten months' imprisonment and a fine. ${ }^{141}$ Similar to the cases of B. and E.M. examined above, the stereotype that domestic violence victims 'asked for it' is at work in the domestic court's decision. This time, however, the links between this stereotype and the consequence for the woman are obvious and concrete: they served to mitigate the original sentence against the perpetrator. Amnesty International's report on domestic violence in Turkey, referred to by the Court in the judgment, highlighted how the Turkish police and courts 'accord [men] undue leniency in sentencing, on the grounds of "provocation" by their victim and on the flimsiest of evidence.' ${ }^{142}$

Opuz is a landmark case in many respects, including that, for the first time, the Court addressed domestic violence as an issue of gender discrimination. ${ }^{143}$ The Court did not just find violations of Articles 2 and 3 ECHR but also of Article 14 ECHR, read jointly with the two other provisions. The Court reasoned:

Bearing in mind its finding above that the general and discriminatory judicial passivity in Turkey, albeit unintentional, mainly affected women, the Court

137 Cook and Cusack (n 5) 27.

138 Radhika Coomaraswamy, "Violence against Women and "Crimes of Honour" in Lynn Welchman and Sara Hossain (eds), 'Honour': Crimes, Paradigms, and Violence against Women (Spinifex Press and Zed Books 2005) xi.

139 Opuzv Turkey (2010) 50 EHRR 28, para 121.

$140 \quad$ Ibid para 57 (emphasis added).

141 Ibid.

142 Ibid para 101. See also para 103.

143 Also, and following Bevacqua and S. v Bulgaria App no 71127/01 (ECtHR, 12 June 2008), para 83, the Court rejects the state's argument that no assistance was required as the dispute concerned a 'family' or 'private matter'. The Court found the lack of assistance incompatible with the state positive obligations to secure the enjoyment of the applicants' rights. ibid. paras 143-144. 
considers that the violence suffered by the applicant and her mother may be regarded as gender-based violence which is a form of discrimination against women. ${ }^{144}$

In reaching this conclusion, the Court relied, inter alia, on reports suggesting that the Turkish authorities tolerated domestic violence. ${ }^{145}$ The Court noted for example how these authorities usually considered the problem a 'private matter' and mitigated sentences 'on the grounds of custom, tradition or honour'. ${ }^{146}$

In this way, and even though the word 'stereotype' does not feature in the reasoning, the Court makes an effort to name some of the police and courts' attitudes underpinning their unresponsiveness to domestic violence. The Court acknowledges that honour was one of the grounds on which Turkish courts mitigated sentences. However, the Court does not address the victim's 'provocation' - let alone the embedded gender stereotypes - that led to reducing the sentence against the applicant's husband for murdering her mother. The Court could have scrutinised the role of provocation when assessing the effectiveness of the criminal investigations into the killing of the applicant's mother under Article 2 ECHR. Moreover, it could have brought the gender stereotypes implicit in this notion more centre stage when assessing the domestic authorities' attitudes behind their overall passiveness under Article 14 ECHR. In sum, the links with the gender stereotypes at the root of both the violent incidents and the ensuing state responses remain partly elusive in the Court's reasoning in Opuz.

Before moving on to the next part, several remarks can be made based on the analysis of the cases discussed above. One of them concerns the image of the female victim of domestic violence. The broad stereotypical image of women underlying all the cases examined in this part is that of the passive, helpless, submissive, tolerant, dependent and vulnerable woman. In all cases, the applicants seem to be sanctioned either with violence from male partners/relatives or with inadequate protection from the state because they are perceived as defying these notions of 'proper' female attributes or roles. Thus, the Opuz applicant appears to be 'punished' with violence for 'wandering outside' her marital home instead of devoting herself to homemaking and caregiving. The applicants in the other cases are denied effective protection and access to justice to varying extents partly for asserting themselves against male dominance. Some applicants do it by using violence, thereby defying the stereotype that women ought to stand violence passively. Others do it by 'provoking' the perpetrator, thus flouting the stereotype that women ought to submit to male authority.

As a result, states end up interrogating women's behaviour while obscuring or justifying that of the perpetrators. This focus on women as the problem thus

\footnotetext{
$144 \quad$ Ibid para 200.

$145 \quad$ Ibid para 197.

146 Ibid paras 195-196.
} 
minimises the violent behaviours of the perpetrators or, even worse, renders them invisible. Moreover, and as Melanie Randall explains, 'a focus on, and preoccupation with, women's reactions to sexual assault, or, for that matter, to any form of gendered violence, begs the question of why the violence against women occurred in the first place'. ${ }^{147}$

To be sure, the Court does not re-enact the gender stereotypes implicit in the state responses at the domestic level or in their submissions at Strasbourg. Perhaps most important, the Court has largely stayed away from the protective and patronising depictions of women feminists worry about. The Court has actually been reluctant to consider women inherently vulnerable to domestic violence $^{148}$ while acknowledging, in some cases, that the issue affected them disproportionately. ${ }^{149}$ In fact, the Court has recognised that domestic violence does not only affect women but that 'men may also be the victims of domestic violence and, indeed ... children, too, are often casualties of the phenomenon, whether directly or indirectly'. ${ }^{\prime 50}$ Though the Court has not shown much appreciation of intersectionality in its domestic violence case law, it has recognised in Opuzv Turkey that some women may be particularly vulnerable to domestic violence as a result of their individual experiences and social background. ${ }^{151}$ As we have seen above, the Court has also condemned, albeit rarely, some of the problematic attitudes underpinning states' ineffective responses to domestic violence. Yet, despite the significance of all these efforts, the Court has remained largely silent on what international human rights law has considered one of the causes at the root of domestic violence and state unresponsiveness: gender stereotypes. In other words, these stereotypes still remain relatively under-scrutinised in the Strasbourg domestic violence cases.

We therefore argue that the Strasbourg Court's reasoning in these cases should include efforts to name any gender stereotypes at the root of the problem and to scrutinise any harmful burdens placed on the victim. In adopting this approach, the Court will contribute to illuminating the structural causes of gendered violence rather than simply placing the responsibility on the actions of isolated individual perpetrators. Moreover, this approach will enable the Court to frame the case as one that is gender-based with the implications discussed in the next part.

\footnotetext{
147 Melanie Randall, 'Sexual Assault Law, Credibility, and "Ideal Victims": Consent, Resistance, and Victim Blaming' (2010) 22 Can JWL 423.

148 The Court has increasingly acknowledged the vulnerability of domestic violence victims but has not considered women as such inherently vulnerable to domestic violence. The recognition has ranged from a more individualised and contextualised assessment of the vulnerability of particular victims (eg Opuzv Turkey (2010) 50 EHRR 28, para 160; and Eremia $v$ the Republic of Moldova (2014) 58 EHRR 2, para 61) to more categorical declarations that domestic violence victims are particularly vulnerable (eg Bevacqua and S. v Bulgaria App no 71127/01 (ECtHR, 12 June 2008) para 65).

151 Ibid para 160.
} 


\subsection{CONTESTING GENDER STEREOTYPES}

The preceding part showed that many of the Strasbourg Court's domestic violence cases contain evidence of gender stereotyping. How the Court should proceed to contest these stereotypes depends on where the stereotyping comes from: the individual perpetrator of violence, or the state.

\subsubsection{Contesting Individuals' Stereotyping: States' Positive Obligations}

The preceding part showed that the Strasbourg Court has come across at least one instance $(O p u z)$ where a man was violent because his partner did not cook, spent too much time outside the house, or was otherwise not conforming to her 'proper' roles. We propose that the Court explicitly calls attention to these incidents of stereotyping in its legal reasoning, in an effort to name the problem. The Court thereby assumes a more pedagogical role, pointing out to the member states where the roots of the problem of domestic violence often lay. In our view, the Court could do this under Article 2 ECHR (the right to life), Article 3 ECHR (the prohibition of torture and inhuman or degrading treatment), Article 8 ECHR (the right to respect for private and family life) or Article 14 ECHR (the prohibition of non-discrimination); whichever is more appropriate depending on the facts of the case.

This raises the question what the legal responsibility of the state is in such cases. In response to the dilemma of how the state can address violence perpetrated by individuals in the private sphere, international human rights law has developed the standard of due diligence. ${ }^{152}$ In essence, this entails that states shall act with due diligence to prevent, investigate, punish and provide for reparation for violence committed by non-state actors. ${ }^{153}$ In the past, the due diligence standard has been criticised for being vague, ${ }^{154}$ but the Istanbul Convention draws out the precise implications of this standard in several provisions. Two of these provisions focus explicitly on gender stereotypes. Thus, in the Chapter on prevention, Article 12.1 IC provides that states should take 'measures to promote changes in the social and cultural patterns of behaviour of women and men with a view to eradicating prejudices, customs, traditions and all other practices which are based on the idea of the inferiority of women or on stereotyped roles for women and men'; and Article 14.1 IC stipulates that states shall take 'the necessary steps to include

\footnotetext{
${ }_{152}$ See eg Carin Benninger-Budel (ed), Due Diligence and Its Application to Protect Women from Violence (Martinus Nijhoff 2008).

153 The Istanbul Convention has codified this standard as follows: 'Parties shall take the necessary legislative and other measures to exercise due diligence to prevent, investigate, punish and provide reparation for acts of violence covered by the scope of this Convention that are perpetrated by non-State actors' (Article 5(2)).

154 eg Holtmaat (n 28) 88.
} 
teaching material on issues such as equality between women and men, nonstereotyped gender roles...'.

Apart from in the Opuz judgment, ${ }^{155}$ the term 'due diligence' has not really taken root in the case law of the Strasbourg Court. ${ }^{156}$ Instead, the Court prefers to use the concept of 'positive obligations'. Mowbray has described positive obligations as 'the duty upon states to undertake specific affirmative tasks'. ${ }^{157}$ Under Article 3 ECHR, for example, the Court has stipulated that Council of Europe States must set up 'a legislative framework aimed at preventing and punishing ill-treatment by private individuals' and that, when the authorities are aware of an imminent risk of violence, they should apply the relevant laws, thus protecting the victims and punishing the perpetrators. ${ }^{158}$ The Court has also developed jurisprudence on the kind of investigation states have to lead in domestic violence cases. ${ }^{159}$

It is beyond the scope of this chapter to map all positive obligations related to domestic violence. ${ }^{160}$ Important for our purposes is that, as it stands, the Strasbourg Court's jurisprudence does not contain any positive obligations which require the state to actively address the root causes of domestic violence. To borrow a metaphor from Rebecca Cook and Simone Cusack: ${ }^{161}$ the Court treats the symptoms, but not the disease. There is nothing on the states' duty to promote a change in societal attitude regarding violence against women, nor is there any mention of obligations to address the widespread existence of gender stereotypes which cause this violence. In light of the state-of-the-art in international human rights law and the Istanbul Convention, we think this is a gap that the Court should close. In cases where gender stereotypes clearly caused individuals to be violent towards their partners or family members, the Court should point this dynamic out and use this to convince the states of the importance of combating gender stereotyping as a root cause of domestic violence against women. The Court could refer to the Istanbul Convention in order to give the argument added force, ${ }^{162}$ especially when the respondent state has ratified this Convention, and

155 See Opuz v Turkey (2010) 50 EHRR 28 para 131: 'As it appears from the parties' submissions, a crucial question in the instant case is whether the local authorities displayed due diligence to prevent violence against the applicant and her mother, in particular by pursuing criminal or other appropriate preventive measures against H.O. despite the withdrawal of complaints by the victims'. 
encourage the states to initiate educational programmes, awareness campaigns or other initiatives to combat such stereotypes. The choice of means falls within the state's margin of appreciation.

\subsubsection{Contesting Gender Stereotyping by the State: Discrimination}

When the state uses gender stereotypes in cases of domestic violence, we again propose that the Court explicitly calls attention to this dynamic. In this part we will argue that when there is any indication in a case file that the state gender stereotyped the victim and/or the perpetrator of domestic violence the Strasbourg Court has to analyse the case as one of direct sex discrimination.

So far, however, the ECtHR's approach to discrimination in domestic violence cases is inconsistent and confusing. Arguably, the Court's case law in that sense reflects the contestation in international human rights law regarding the extent to which domestic violence is gendered. ${ }^{163}$ Looking at judgments concerning domestic violence against women ${ }^{164}$ delivered in the period since the groundbreaking judgment in Opuz - the first judgment to find a violation of Article 14 ECHR - the statistics are as follows:

- $\quad$ violation of Article 14: four cases (including Opuz itself); ${ }^{165}$

- no violation of Article 14: one case; ${ }^{166}$

- Article 14 complaints inadmissible: two cases; ${ }^{167}$

- no examination of Article 14 whatsoever: seven cases. ${ }^{168}$

These statistics show that in half of the cases the Court does not examine domestic violence from a discrimination perspective at all. What lies behind these statistics is incoherent and often unconvincing legal reasoning of the Court. In Opuz the Court held that 'the State's failure to protect women against domestic violence breaches their right to equal protection of the law and that this failure does not need to be intentional'. ${ }^{169}$ It noted that there was general 'judicial passivity' in

Czech Republic App no 59552/08 (ECtHR GC, 27 January 2015) para 38.

163 See above section 2.2 and Römkens (n 32).

164 Thus, these statistics do not include (in)admissibility decisions, nor do they include cases where the only victims of domestic violence were children.

165 Opuzv Turkey (2010) 50 EHRR 28, and later followed Eremia v the Republic of Moldova (2014) 58 EHRR 2; Mudric $v$ the Republic of Moldova App no 74839/10 (ECtHR, 16 July 2013); and T.M. and C.M. $v$ the Republic of Moldova App no 26608/11 (ECtHR, 28 January 2014).

166 Rumor v Italy App no 72964/10 (ECtHR, 27 May 2014).

167 A. $v$ Croatia (2015) 60 EHRR 26; Kalucza v Hungary App no 57693/10 (ECtHR, 24 April 2012).

168 E.S. and others $v$ Slovakia App no 8227/04 (ECtHR, 15 September 2009); Hajduová v Slovakia (2011) 53 EHRR 8; Y.C. $v$ the United Kingdom App no 4547/10 (ECtHR, 13 March 2012); Valiuliené v Lithuania App no 33234/07 (ECtHR, 26 March 2013), apart from the dissent; B. $v$ the Republic of Moldova App no 61382/09 (ECtHR, 16 July 2013); N.A. $v$ the Republic of Moldova App no 13424/06 (ECtHR, 24 September 2013); Durmaz v Turkey App no 3621/07 (ECtHR, 13 November 2014).

169 Opuzv Turkey (2010) 50 EHRR 28 para 191. 
Turkey, which amounted to discrimination as this 'created a climate that was conducive to domestic violence. ${ }^{170}$ In the other three cases in which the Court found a violation of Article 14 ECHR - incidentally all three cases against the Republic of Moldova - it also noted that the passivity of the authorities in the face of domestic violence amounted to condoning such violence and thereby discriminating against women. In these four cases the Court took a gender perspective to domestic violence - which then let it find a violation of Article 14.

In the numerous domestic violence cases where the Court did not examine at all whether there was an issue of discrimination, however, the Court omitted to take a gender perspective. In these cases the Court makes a purely individual assessment, without really taking into account the fact that, as was explained in section 1.2, domestic violence is a distinctly gendered phenomenon which affects women disproportionality and as such a systemic problem affecting state response.

In the preceding part we identified either implicit or explicit gender stereotyping by the state in the cases of Opuzv Turkey, Eremia v Moldova, Kalucza $v$ Hungary, E.M. $v$ Romania, B. $v$ the Republic of Moldova, and Valiuliene $v$ Lithuania. These are cases of sex discrimination, we will argue further below. First we wish to emphasise however that evidence of gender stereotyping should not be seen as sine qua non for a finding of discrimination: consistent passivity in the face of domestic violence - such as occurred in the cases of Mudric $v$ the Republic of Moldova and T.M. and C.M. $v$ the Republic of Moldova - can also be enough to find a violation of Article 14 ECHR. In other words: gender stereotyping is a sufficient condition for a finding of discrimination, but not a necessary condition.

Explicating the connections between gender stereotyping and discrimination in domestic violence cases is no easy task for the Strasbourg Court. Section 2.2 showed that these connections are complex and that there is the added concern of reinforcing patronising stereotypes of women as helpless victims. It might be helpful for the Court to conceive of the relation between gender stereotyping and discrimination as one of a vicious, self-reinforcing circle. ${ }^{171}$ Gender stereotyping is both the cause and manifestation of gender discrimination. Gender stereotypes are also used to rationalise/justify discrimination, which in turn further reinforces discrimination. The circle thus looks like this:

In the context of domestic violence this circle goes as follows: most domestic violence victims are women. This situation is rationalised or justified by the authorities by gender stereotypes such as 'women ought to be submissive' and 'women (ought to) endure men's aggressiveness'. These ideas make that the authorities do not act at all on the violence, or act weakly (eg with lots of delays). This in turn causes domestic violence to continue with impunity, both at an individual level and in society.

\footnotetext{
$170 \quad$ Ibid para 198.

171 See also Timmer (2015) (n 4) 281-282.
} 
The Court can build on its existing case law, specifically Konstantin Markin, in affirming that gender stereotypes cannot be a justification for discrimination. In the context of domestic violence, this means that the state cannot rely on gender stereotypes in order to defend its passivity in domestic violence cases. What the Court urgently needs to develop in terms of new legal reasoning is the idea that gender stereotyping causes discrimination (ie the third part of the circle). Regrettably, there are many cases currently pending which concern domestic violence against women, ${ }^{172}$ so the Court will have plenty of opportunity to develop its reasoning.

\section{CONCLUSION}

International human rights law has made significant progress in recognising the role that gender stereotypes play in violence against women and in combating these stereotypes. The Strasbourg Court, however, has remained largely silent on the issue. To be sure, the Court has recognised that justifications for differences in treatment based on gender stereotypes will render such differences discriminatory. This recognition, we have argued, should make headway in the Court's domestic violence case law. States should not be allowed to rely on gender stereotypes to justify their unresponsiveness in domestic violence cases. Moreover, states should be required to actively address the gender stereotypes at the root of domestic violence. In naming and contesting gender stereotypes, the Court will be not just illuminating the structural causes of the phenomenon. It will be joining international human rights law efforts to tackle them.

eg Kılıçv Turkey App no 63034/11; Cămărăşescu v Romania App no 49645/09; and Munteanu $v$ Republic of Moldova App no 34168/11. 



\title{
GENDER STEREOTYPING IN THE CASE LAW OF THE INTER-AMERICAN COURT OF HUMAN RIGHTS
}

\author{
Verónica UNDURRAGA*
}

This chapter reviews the case law of the Inter-American Court of Human Rights (the Inter-American Court or the Court) on gender stereotyping. The text begins with a brief introduction to the inter-American human rights system. The following sections concentrate on the flagship cases of the jurisprudence of the Court on stereotyping, González ('Cotton Field') Case v Mexico ${ }^{1}$ and the case of Atala Riffo and Daughters $v$ Chile, ${ }^{2}$ to show how these rulings are representative of the Court's approach to the issue of stereotyping, and more generally, of its conception of equality - and gender equality - as substantive and transformative. The strong concern of the Court regarding structural patterns of discrimination results in an analysis of individual human rights violations that is enriched by an understanding of those cases as instances of more pervasive situations of subordination, exclusion and violence. Through its rulings, the Court seeks not only to redress the individual victims of the cases, but also to improve the underlying conditions that made the rights violations possible, and to generate an institutional and cultural environment that would prevent those violations from happening again. In particular, the mission assumed by the Court of debunking gender stereotypes through adjudication is fraught with difficulties. The last part of the text refers to some challenges the Court has confronted or may confront in the future which deserve attention from human rights scholars and activists.

\footnotetext{
* A previous draft of this chapter served as inspiration for an article I co-authored with Catalina Eggers and that is included in Gabriela Pacheco and others (eds), Estudios en Homenaje a Cecilia Medina Quiroga (Tirant Lo Blanch (forthcoming)). I want to thank Catalina Eggers for her valuable contribution as research assistant in this English version. González ('Cotton Field') Case IACtHR Ser C No 205 (16 November 2009). Atala Riffo and Daughters Case IACtHR Ser C No 239 (24 February 2012).
} 


\section{THE INTER-AMERICAN HUMAN RIGHTS SYSTEM}

The inter-American human rights system is the regional mechanism for the protection of human rights in the Americas. It includes the Inter-American Commission on Human Rights (the Inter-American Commission or the Commission) and the Inter-American Court. The Commission, an autonomous organ of the Organization of American States (OAS), promotes and protects human rights and serves as a consultative organ of the OAS on human rights issues. ${ }^{3}$ The Commission monitors the human rights situation in member states by making country visits and issuing thematic or country reports. It also has a quasi-judicial function, as it processes and analyses individual petitions regarding human rights violations, supervises friendly settlements, issues recommendations to states, intervenes in urgent cases by adopting precautionary measures, and takes cases to the Court. The Commission's competence in relation to the State Parties to the American Convention on Human Rights (American Convention) ${ }^{4}$ is established in that treaty, while its competence with respect to states that are members of OAS but not parties to the American Convention is based on the provisions of the OAS Charter and on its own practice. When the Commission rules on a case regarding a state that is nor party to the American Convention (such as the United States or Canada) it bases its report on the American Declaration of the Rights and Duties of Man, ${ }^{5}$ which despite having been adopted as a declaration and not as a treaty, is considered a source of international obligations for states that are members of the OAS. ${ }^{6}$

The Court interprets and applies the American Convention and the other human rights instruments adopted by member states. The Court decides on cases that are brought before it by the Commission or by State Parties to the American

$3 \quad$ Charter of the Organization of American States (entered into force 13 December 1951) 119 UNTS 3; amended by Protocol of Buenos Aires (entered into force 27 February 1970) 721 UNTS 324 OAS Treaty Series No 1-A; amended by Protocol of Cartagena (entered into force 16 November 1988) OAS Treaty Series No 6625 ILM 527; amended by Protocol of Washington (entered into force 25 September 1997) 1-E Rev OEA Documentos Oficiales OEA/Ser.A/2 Add. 3 (SEPF) 33 ILM 1005; amended by Protocol of Managua (entered into force 29 January 1996) 1-F Rev OEA Documentos Oficiales OEA/Ser.A/2 Add 4 (SEPF) 33 ILM 1009.

4 American Convention on Human Rights (adopted 22 November 1969, entered into force 18 July 1978) OAS Treaty Series No 361144 UNTS 123; reprinted in Basic Documents Pertaining to Human Rights in the Inter-American System OEA/Ser LV/II.82 Doc 6 Rev 1 at 26 (1992).

5 American Declaration of the Rights and Duties of Man OAS XXX adopted by the Ninth International Conference of American States (1948) reprinted in Basic Documents Pertaining to Human Rights in the Inter-American System (BDPHR) OEA/Ser LV/II.82 Doc 6 Rev1 at 17 (1992).

$6 \quad$ Interpretation of the American Declaration of the Rights and Duties of Man Within the Framework of Article 64 of the American Convention on Human Rights, Advisory Opinion OC-10, IACtHR Ser A No 10 (14 July 1989); Statute of the Inter-American Commission on Human Rights (IACmHR), OAS Res 477 (IX-O/79) OAS Rec OEA/Ser P/IX.0.2/80, Vol 1-88 Annual Report of the IACmHR OEA/Ser. L/V11.50 doc 13 Rev 1-10 (1980) reprinted in the BDPHR OAS/Ser LV/II.82 Doc 6 Rev 1 at 93 (1992). 
Convention, and it might intervene in urgent cases by issuing provisional measures. The Court also delivers advisory opinions in response to consultations regarding the interpretation of the American Convention or other inter-American human rights treaties.

\section{GENDER AND GENDER STEREOTYPING IN THE INTER-AMERICAN HUMAN RIGHTS SYSTEM}

The Court delivered its first decision on the merits in 1988. ${ }^{7}$ But not until 2006 did its then President declare that the Court had been presented for the first time with a case involving women's rights issues. ${ }^{8}$ It was the case of the Miguel Castro Castro Prison v Peru. ${ }^{9}$

This statement is surprising, to say the least, considering that the Court had in the past decided on several cases involving women victims, including a case where a woman was abducted, kept naked during detention and then made to disappear, ${ }^{10}$ another where a woman was sexually threatened in the context of an armed conflict, ${ }^{11}$ a third case where a prisoner was bound, blindfolded, beaten, touched all over her body, undressed, repeatedly raped by a gang of military men and then plunged into the sea, ${ }^{12}$ and a case were almost all the girls and women of a Mayan village were separated from their male and older relatives to be raped and then were shot at and burned to death. ${ }^{13}$ The President of the Court's declaration can be interpreted as a covert criticism to the Commission for not having taken women rights cases to the Court, but what it really shows is that until 2006 the Court was blind to the fact that these previous cases had also involved women's rights violations. It was not the facts of the Castro Castro case that were special in comparison to previous cases involving women's victims. It was the Court's perspective that had changed.

The Court for the first time explicitly addressed the issue of stereotyping in the González Case v Mexico, ${ }^{14}$ decided on in 2009, best known as the Cotton Field case, because the dead bodies of the victims were found in a cotton field of Ciudad Juárez, in Mexico. To date, the Court has also referred to gender and compound stereotypes in the cases of Atala Riffo and Daughters $v$ Chile, ${ }^{15}$ Artavia Murillo

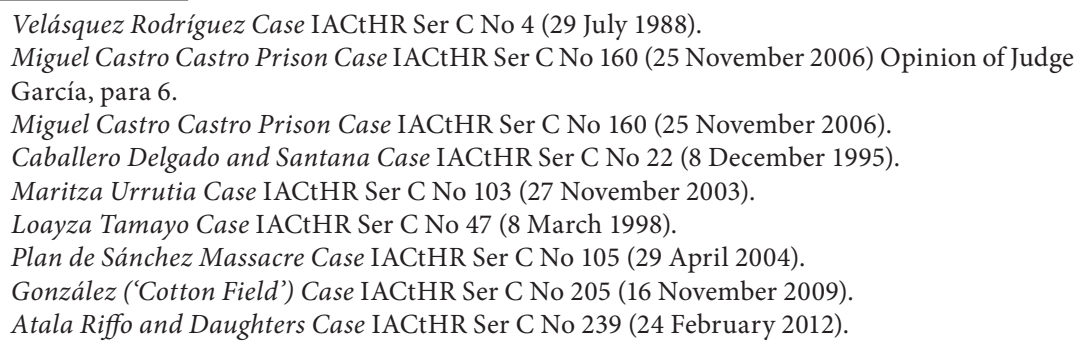


('In Vitro Fertilization') v Costa Rica, ${ }^{16}$ Fornerón and Daughter v Argentina, ${ }^{17}$ Veliz Franco $v$ Guatemala, ${ }^{18}$ and in Espinoza Gonzales $v$ Peru. ${ }^{19}$ In my comments below I will make reference to these cases, except for Veliz Franco, which applies the same reasoning of the Cotton Field case to the disappearance of a young woman in Guatemala, and Espinoza Gonzales, which is an interesting case in which the Court makes a thorough analysis of the operation of gender stereotypes in forensic reports resulting in Peruvian courts discarding the testimony of a victim of torture during the armed conflict in Peru. Recently, the Court issued its first decision on ethnic stereotyping in Norin Catrimán $v$ Chile, ${ }^{20}$ which the Court built upon its precedents on gender stereotyping. ${ }^{21}$

In the following sections of this text, I present the two leading cases of the jurisprudence of the Court on stereotyping: the Cotton Field case and the Atala case. I will show how the Court identified and named the stereotypes at work on those decisions and how the operation of stereotypes resulted in the violation of women's rights under the American Convention. I will argue that the most valuable aspect of the Court's approach is the connection it makes between stereotyping and structural discrimination and its attempts to redress that relationship by means of reparation measures imposed on states that were found responsible under international human rights law. I will then refer to some challenges the Court has confronted or may confront in the future regarding its assumed mission of debunking gender stereotypes through adjudication.

\subsection{THE COTTON FIELD CASE}

The case of González v Mexico is about the disappearances and murders of three young and underprivileged women, Laura Ramos, a 17-year-old student, Claudia González, a 20-year-old worker in the maquiladora industry, and Esmeralda Herrera, a 15-year-old domestic employee. They disappeared in different circumstances in September and October of 2001.

When the victims' next of kin requested the help of the state officials and municipal authorities, these officials did not begin any effective search, minimised the gravity of the situation, ${ }^{22}$ discredited the reports of the family members by

\footnotetext{
Artavia Murillo ('In Vitro Fertilization') Case IACtHR Ser C No 257 (28 November 2012).

Fornerón and Daughter Case IACtHR Ser C No 242 (27 April 2012).

Veliz Franco $v$ Guatemala Case IACtHR Ser C No 277 (19 May 2014).

Espinoza Gonzáles v Peru Case IACtHR Ser C No 289 (20 November 2014).

Norín Catrimán (Leaders, members and activist of the Mapuche Indigenous People) Case IACtHR Ser C No 279 (29 May 2014).

21 The Commission has also confronted interesting individual cases dealing with gender stereotyping. See Morales de la Sierra Case IACmHR No 11.625 Rep No 28/98 OEA/Ser L/V/ II.95 Doc 7 Rev at 136 (1997); Jessica Gonzalez Case IACmHR No 1490-05 Report No 52/07 OEA/Ser L/V/II.130 Doc 22 Rev 1 (2007); MZ Case IACmHR No 12.350 Report No 103/14 OEA/Ser L/V/II.153 Doc 19 Rev (2014).

22 González ('Cotton Field’) Case IACtHR Ser C No 205 (16 November 2009) para 200.
} 
comments such as that 'they were young girls who were out with their boyfriends or friends having a good time', that 'girls were very flighty and threw themselves at men', ${ }^{23}$ blamed the victims for not staying at home as good girls $\mathrm{do}^{24}$ and even criticised their mothers for allowing their daughters to go out alone. ${ }^{25}$ The relatives were made to fill missing person forms with information regarding the routines, sexual preferences and behaviour of the victims. This information was required to determine whether the missing women should or should not justify immediate search, which would be undertaken only if their cases met the criteria of 'high risk disappearances'. Under this policy, the authorities asked for evidence that the victims were young women who followed stable routines, had no reason to abandon their homes and had disappeared in circumstances similar to those associated with serial killings. ${ }^{26}$

A worker passing through a cotton field in Ciudad Juárez found the bodies of Laura, Claudia and Esmeralda, in November of 2001. They were partly nude, with signs that showed that they were subjected to extreme cruelty and most probably rape. ${ }^{27}$ Esmeralda suffered the mutilation of her right breast and left nipple, and Laura of one of her nipples.

After the bodies were found, the custody of the crime scene, the collection and handling of evidence, autopsies and identification and return of the victims' remains, among other aspects, were handled by the authorities in highly irregular ways. There was unjustified delay in the investigations and, when authorities faced public pressure for their lack of substantial progress, they falsely accused two men, who were tortured and made to confess to the crimes. Public officials involved in these irregularities were not punished.

The context of the case is relevant. Ciudad Juárez is an industrial city located on the border of El Paso, Texas, where the maquila industry has flourished, especially since the North Free Trade Agreement entered into force in 1994. It is a place of transit and, at the time of the facts of the case, it was the site of all kinds of organised crimes, such as people trafficking, drug deals, arms smuggling and money laundering - a site of great social inequalities and violence.

The crimes of Laura, Claudia and Esmeralda were by no means extraordinary or isolated events. From the late 1990s, Ciudad Juárez became a focus of the attention of the international human rights community due to the critical situation of violence against women, ${ }^{28}$ including an anomalous increase of murders of women, which doubled the coefficient of murders of men and was disproportionally higher than the murder rates of other border cities with similar

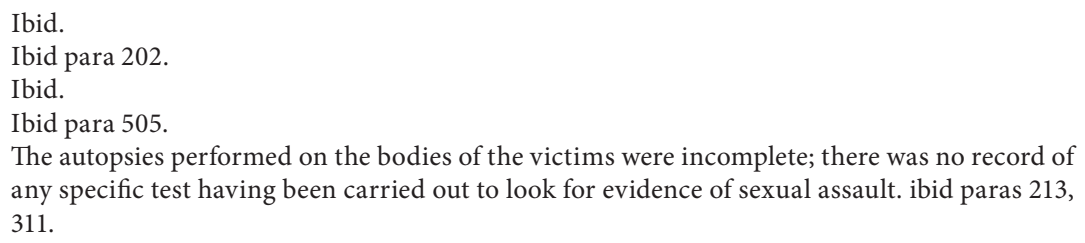
any specific test having been carried out to look for evidence of sexual assault. ibid paras 213, 311.

$28 \quad$ Ibid para 116. 
characteristics. The Court found that the manifestations of gender violence in Ciudad Juárez, including the murders, kidnappings, disappearances and also cases of domestic violence, constituted a social and cultural phenomenon of structural gender discrimination. ${ }^{29}$

The Court described the patterns common to most of the cases of gender violence in Ciudad Juárez: victims were, disproportionately, young and vulnerable students or factory workers; they were abducted, kept against their will and after days or months their bodies were found on empty lots, bearing the signs of violence, including rape and other type of sexual abuse; there were delays and gross irregularities in conducting the investigations, incompetence and insensitivity on the part of the authorities, discriminatory attitudes towards the victims and their relatives, which included blaming them for their fate, made light of the events and the use of sexist stereotypes; lack of transparency in the procedures; and a general climate of impunity.

The context analysis offered by the Court was essential to rebut the State's contentions denying its responsibility for the crimes. The Court condemned the State not because state officials were the direct perpetrators, but because it failed to act diligently to protect the victims once the State had concrete information about their disappearances. The concrete duty to act in these cases resulted from the fact that, at the time the state officials received the testimony of the next of kin informing that the women were missing, the State had clear knowledge of the situation of high risk for women in Ciudad Juárez, and that there was a real and imminent danger that the victims would be sexually abused and killed. ${ }^{30}$ The general standard of the due diligence obligation is reinforced when victims are children (as Esmeralda and Laura were) who are accorded special protection under Article 19 of the American Convention, ${ }^{31}$ and when the state is under the specific conventional mandate to prevent, punish and eradicate violence against women contained in Article 7(c) of the Belem do Pará Convention. ${ }^{32}$

The Court cited Mexico's observations to the Report produced by the CEDAW Committee under Article 8 of the Optional Protocol to the CEDAW, ${ }^{33}$ recognising that the homicides of women in Ciudad Juárez were influenced by a culture of discrimination against women based on the erroneous idea that women are inferior' and that such culture also influenced the fact that the murders 'were not perceived at the outset as a significant problem requiring immediate and forceful action on the part of the relevant authorities. ${ }^{34}$

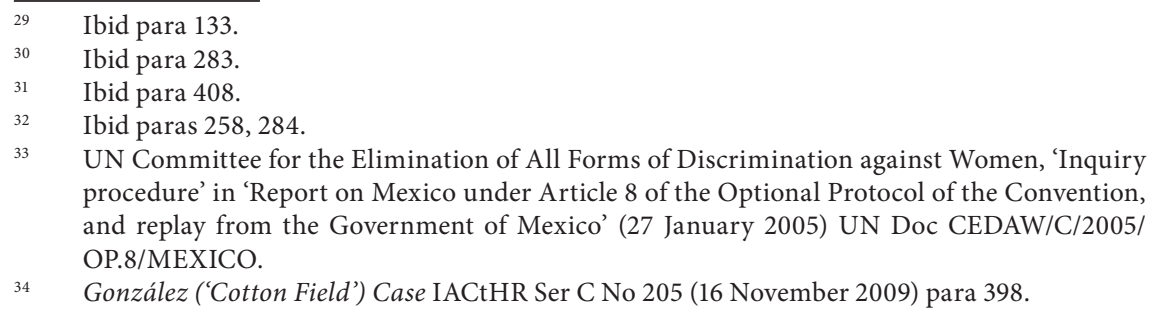
procedure' in 'Report on Mexico under Article 8 of the Optional Protocol of the Convention, and replay from the Government of Mexico' (27 January 2005) UN Doc CEDAW/C/2005/ OP.8/MEXICO.

34 González ('Cotton Field’) Case IACtHR Ser C No 205 (16 November 2009) para 398. 
The Court noted that the sudden and dramatic transformation of gender roles, resulting from the massive incorporation of women in the maquila industry, led to conflicts within the families because women, who traditionally had complied with their stereotyped role of housewives, challenged that stereotype by becoming the household providers and were perceived as more competitive and financially independent. This economic transformation was not accompanied by a change in traditional patriarchal mentalities. The abnormal increase of crimes against women could be explained as motivated by a hierarchical use of terror and violence aimed at keeping women in their traditionally subordinated roles. ${ }^{35}$ The sexual nature of most of the crimes, including not only rape but also mutilation of breasts and genitalia, and the fact that the bodies were left in the open to be found, are signs that show the gendered character of the crimes and their expressive function.

The Court drew on the definition of gender-based violence contained in the Inter-American Convention on the Prevention, Punishment and Eradication of Violence against Women (Belem do Pará Convention) ${ }^{36}$ and on the definition of femicide violence established in the Mexican General Law on Access of Women to a Life Free of Violence, ${ }^{37}$ to conclude that the crimes of Laura, Claudia and Esmeralda should be qualified as gender-based violence - violence directed toward a woman because she is a woman or that affects women disproportionately and not merely acts of generalised violence. It also relied on the Belem do Pará Convention, on CEDAW's General Recommendation No 19 on Violence Against Women, ${ }^{38}$ and on several reports of human rights bodies and organisations, to consider gender-based violence as a form of discrimination. ${ }^{39}$ The Court found

35 María Mercedes Gómez, 'Los Usos Jerárquicos y Excluyentes de la Violencia' in Rodolfo Arango et al (ed), Más allá del Derecho: Justicia y Género en América Latina (Bogotá Siglo del Hombre, Red Alas Los Andes U 2005).

36 The Inter-American Convention on the Prevention, Punishment and Eradication of Violence against Women (adopted 9 June 1994 entered into force 5 March 1995) IACmHR (1994) 33 ILM 1534. Article 1 defines violence against women as 'any act or conduct, based on gender, which causes death or physical, sexual or psychological harm or suffering to women, whether in the public or the private sphere'.

37 Ley General de Acceso de las Mujeres a una Vida Libre de Violencia, 2007 (Mexico) <www.consejeria.df.gob.mx/portal_old/uploads/gacetas/Enero08_\%2029_263.pdf> accessed 5 September 2015. Article (VII) defines femicide violence as 'the extreme form of gender violence against women, resulting from the violation of their human rights that can lead to homicide or other forms of violent death of women'.

38 UN Committee for the Elimination of All Forms of Discrimination against Women, 'General Recommendation No 19' in 'Note by Secretariat, Compilation of General Comments and General Recommendations Adopted by Human Rights Treaty Bodies' (29 July 1994) UN Doc HRI/GEN/1/Rev 1.

39 Convention on the Elimination of All Forms of Discrimination against Women (adopted to signature 18 December 1979, entered into force 3 September 1981) UN General Assembly resolution 34/180, 34 UN GAOR Supp. No 46 at 193 UN Doc A/34/46, 1249 UNTS 13. Article 1 defines discrimination against women as 'any distinction, exclusion or restriction made on the basis of sex which has the effect or purpose of impairing or nullifying the recognition, enjoyment or exercise by women, irrespective of their marital status, on a basis of equality of men and women, of human rights and fundamental freedoms in the political, economic, 
that the subordination of women is exacerbated when stereotypes are reflected in the attitude and behaviour of the police and authorities, as they were in this case. Their indifference reproduces the violence that it claims to be trying to counter and perpetuates it by sending the message that violence against women is tolerated. This too constitutes discrimination regarding access to justice.

Besides identifying a violation to the obligation not to discriminate contained in Article 1(1) of the Convention, the Court held that the State of Mexico violated the rights of life (Article 4(1)), personal integrity (Article 5(1) and (2)) and personal liberty (Article 7(1)) of the three victims because it did not comply with its obligation to guarantee such rights (Article 1(1)) and the obligation to adopt domestic legal provisions (Article 2) as required by the American Convention, in connection to the obligations established in Articles 7(b) and (c) of the Belem do Pará Convention. The Court further held that the State violated the right to personal integrity (Article 5(1) and (2)) and the right to access to justice (Article 8(1)) and the right to judicial protection (Article 25(1)) in connection with Articles 1(1) and 2 of the American Convention and Article 7(b) and (c) of the Belém do Pará Convention, as regards the victims' next of kin.

\subsection{THE ATALA CASE}

In 2012, the Court ruled on the case of Atala Riffo and Daughters $v$ Chile. ${ }^{40}$ It declared that the Chilean state was responsible for discriminatory treatment and arbitrary interference in on account of Ms Atala's sexual orientation during in the legal process that resulted in the loss of care and custody of her three daughters, and thus for gravely affecting Ms Atala and her daughters' private and family life.

Ms Atala, a judge, was married to a public defender. When they divorced they agreed that she would have custody of their children, who would spend weekends with their father. Although this was a divorce agreement, it was also the default rule under the Chilean family law at the time, which said that children of divorced parents would remain under the custody of the mother unless agreed otherwise or unless the mother is declared legally incompetent. Both Ms Atala and her ex-husband began new relationships. However, when the girls' father got to know that Ms Atala's partner was a woman and that she was living under the same roof with the children, he filed a custody suit. He argued that, given Ms Atala's new sexual lifestyle and her lesbian cohabitation, she was not longer

social, cultural, civil or any other field.' The definition of discrimination against women 'includes gender-based violence, that is, violence that is directed against a woman [i] because she is a woman or [ii] that affects women disproportionately.' Gender-based violence 'is a form of discrimination that seriously inhibits women's ability to enjoy rights and freedoms on a basis of equality with men'; ibid (n 1) para 133.

40. Atala Riffo and Daughters Case IACtHR Ser C No 239 (24 February 2012). 
capable of watching over the girls, that the physical and emotional development of the girls was seriously at risk, ${ }^{41}$ that Ms Atala had over the years displayed hardly maternal and violent behaviour, and that the respondent's need to be happy and fulfil herself as a person in all areas of her life was not compatible with being a parent and exercising maternal capabilities which, it seemed, the respondent had selfishly disregarded. He also claimed that the children had the right to live in a family made up of a father and a mother of different sexes. ${ }^{42}$

The Family Court granted provisional custody to the father, even though it expressly acknowledged that there was no evidence to presume the legal incompetence of the mother. The Court argued that Ms Atala had altered the normal family routine, giving preference to her personal interests and well-being over carrying out her role as a mother, under conditions that could affect the development of the children. It also said that the father presented more favourable arguments on behalf of the best interest of the girls, arguments that bear great weight in the context of a heterosexual and traditional society. ${ }^{43}$

However, in its decision on the merits, the Acting Judge of the Family Court (the regular judge had been disqualified to continue intervening in the custody proceedings) declared that Ms Atala was a competent mother and dismissed the case. Ms Atala's case also prevailed in the Court of Appeals, but the Supreme Court reversed the decision.

The Supreme Court argued that the best interest of the children should be given priority and that in this case there was a justified cause to entrust the personal care of the girls to the father. The Court said that the lower courts had not given due consideration either to the deterioration of the social environment since the mother began to cohabit with her partner or to the possibility that the girls could be the target of social discrimination arising from this fact, nor to games and attitudes of the girls that reflected confusion about the sexuality of the mother. It is noteworthy that the Supreme Court was not legally empowered to review the lower courts' appreciation of the facts, and further, that the lower courts had decided that the evidence regarding these allegations were speculative, reflecting fears and suppositions instead of real facts.

The Supreme Court considered that Ms Atala had put her own interests before those of her daughters when she chose to live in the same home with a same-sex partner and the girls. The Supreme Court concluded that the lower judges failed by having ignored the right of the minors to live and grow within a family that is normally structured and socially valued within its environment, and which responds to the proper traditional model. ${ }^{44}$

\footnotetext{
$\overline{41} \quad$ Ibid para 31. He argued that the girls would be under constant risk of contracting sexually transmitted diseases such as herpes and AIDS.

$42 \quad$ Ibid para 39.

$43 \quad$ Ibid para 41.

$44 \quad$ Ibid para 57.
} 
Another aspect of the dispute concerns a disciplinary procedure that was conducted by the Court of Appeals against Ms Atala, triggered in part by the publications that appeared in two tabloids informing of the custody suit and of Ms Atala's sexual orientation. The disciplinary procedure involved the checking of Ms Atala's computer and the websites she had visited, the sending of a questionnaire and interrogations of staff members including questions about Ms Atala's sexual orientation. The investigating judge, in his report, concluded that Ms Atala, by openly expressing her 'peculiar emotional relationship' had clearly 'damaged the reputation of both, Ms Atala and the Judiciary.'

The Inter-American Court noted that Ms Atala was subject to a difference of treatment during the custody process, because it revolved around her sexual orientation and not on her individual ability as a mother. The Court explained that a determination based, as it was in this case, on unfounded and stereotyped assumptions about the parent's capacity and suitability to ensure and promote the child's well-being and development is not appropriate for the purpose of guaranteeing the legitimate goal of protecting the children's best interest.

The Court declared that the State was responsible for the violation of the rights to equality and non-discrimination enshrined in Article 24 in conjunction with Article 1(1) and Article 19 of the American Convention, to the detriment of Ms Atala and her daughters; that the State was responsible for the violation of the victims' right to privacy (Article 11(2) in conjunction with Article 1(1)), of the rights of the family (Article 17(1) in conjunction with Article 1(1)) and of the right of the child to be heard (Article 8(1), in conjunction with Articles 19 and 1(1)), and finally, that the State violated the guarantee of impartiality (Article 8(1), in conjunction with Article 1(1)) with respect to the disciplinary investigation, to the detriment of Ms Atala. ${ }^{45}$

The Court declared for the first time that under the American Convention sexual orientation is a prohibited ground of discrimination. It said that sexual minorities had suffered historical and structural discrimination and that states are under the obligation to apply strict scrutiny when differential treatment is based on sexual orientation. States must not only abstain from carrying out any action that, directly or indirectly is aimed at creating situations of de jure or de facto discrimination, but are also obliged to take affirmative measures to reverse or change discriminatory situations that exist in their society to the detriment of a specific group of persons.

The Court clearly identified some of the stereotypes that were playing a role in this case. For example, the stereotype that a good mother should sacrifice even her legitimate interests and essential aspects of her identity for the sake of her children, the stereotype that lesbians are immoral and do not have nurturing capacities and the stereotype that parents are heterosexual. The operation of these stereotypes made the Chilean judiciary rule on the case based not on Ms Atala's

Ibid para 314 . 
actual parenting capacities, but on the judges' prejudices about how women are and how women should behave, resulting in discriminatory treatment during the custody and the disciplinary procedures and in the violation of Ms Atala's and her children' rights.

A noteworthy aspect of this case is how the stereotype of lesbians as bad mothers won over the stereotype of women as natural caregivers, which was entrenched in the law of custody and was present in the negotiation of the divorce agreement. Ms Atala was considered a fit mother until she made public that she was a lesbian. From that moment, she was seen as selfish, hardly maternal, unfit, dangerous and contagious.

\section{SOME COMMON APPROACHES TO BOTH CASES}

These two cases, although very different, are representative of the challenges the inter-American system is confronting at the present time. After a long period in which the Commission and the Court dealt mainly with executions, disappearances and other crimes committed by Latin American dictatorships, now they are facing a context of weak representative democracies threatened by alarming levels of endemic inequality, exclusion, social and institutional violence and ineffective justice systems, all of which create conditions for human rights violations that particularly affect vulnerable and marginalised populations. ${ }^{46}$ All these circumstances are aggravated by the fact that most Latin American societies have recently undergone either armed conflicts or repressive political regimes. In this new context, the work of the Commission and the Court has gone beyond ruling on individual cases; it has adopted a more general and preventive approach aimed at improving domestic institutions and practices by putting forward human rights standards and educating local officials, judges and civil society. Also, the Commission and the Court have shown a strong concern regarding structural patterns of discrimination. Their analysis of individual human rights violations is enriched by their understanding of those cases as instances of more pervasive situations of subordination, exclusion and violence, which could not be dealt with the traditional formal approach to equal treatment, but instead require a substantive and transformative conception of equality. ${ }^{47}$

This substantive conception of equality is articulated in the Court's decisions in several ways that are apparent in the Cotton Field and the Atala cases.

First, the Court recognises a particular human rights violation as part of a pattern of violations affecting individuals of subordinated or vulnerable groups,

$46 \quad$ Victor Abramovich, 'From Massive Violations to Structural Patterns: New Approaches and Classic Tensions in the Inter-American Human Rights System' (2009) 6 (11) Sur-Intl JHR 7.

47 Ibid 18-23. See also Oscar Parra, 'Derechos Humanos y Pobreza en el Sistema Interamericano: el rol del análisis estructural a partir de informes y siete escenarios estratégicos basados en la responsabilidad internacional' (2012) 56 Int-Am Inst HRJ 273. 
such as women or sexual minorities (LGBTI people or LGBTI). Usually, the Court also detects situations in which the victims' situation is aggravated by the intersection of several sources of oppression or disadvantages, such as being women, young and poor, in the Cotton Field case, or being a woman and a lesbian, in the Atala case. This first step requires the Court to pay careful attention to the facts of the case to identify particular features revealing the structural and collective nature of the wrongful actions suffered by the victims. In the Cotton Field case, the Court situated the disappearances and murders of Laura, Claudia and Esmeralda, in the broader context of an increase of violence against women in Ciudad Juárez, which in turn was the effect of a patriarchal reaction to the abrupt transformation of gender roles that resulted from the incorporation of young women to paid labour. Further, the Court realised that the dismissive attitude of the authorities could be explained by the devaluation of the victims, for being young and poor women who were deemed to have exposed themselves to the risk by not conforming to stereotypical feminine roles. The Court identified the extreme violence suffered by the three women as gendered violence, violence that the victims experienced for being women or that women disproportionately suffer. In the Atala case, the Court contextualised the case as an instance of discrimination against women and LGBTI people. It carefully explained how wrongful stereotypes against women and also specific prejudices against lesbians influenced the outcome of the decision of the Chilean Supreme Court, which substituted an individual assessment of Ms Atala's parental capacities with unproved preconceptions about non-conforming sexual minorities.

Second, the Court declares that there is a reinforced state obligation to protect victims that are in situations of vulnerability - such as children ${ }^{48}$ - or are members of subordinated groups with a history of discrimination, such as women or LGBTI people. ${ }^{49}$ In the Cotton Field case, the Court grounded the reinforced obligations towards the victims in the specific conventional mandates contained in Article 19 of the American Convention regarding the right of the child Esmeralda was 15 and Laura was 17 at the time they disappeared - in Article 7 of the Belem do Pará Convention, and in the fact the state authorities were informed and aware of the vulnerable condition of women in Ciudad Juárez at the time the crimes occurred. In the Atala case, the Court applied a strict scrutiny standard to review the differential treatment applied to Ms Atala, because she was a member of sexual minorities historically discriminated for their sexual orientation. ${ }^{50}$

${ }_{48} \quad$ See Street Children (Villagrán Morales) Case IACtHR Ser C No 63 (19 November 1999); Juvenile Reeducation Institute Case IACtHR Ser C No 112 (2 September 2004); Servellón García Case IACtHR Ser C No 152 (21 September 2006). See also Judicial Condition and Rights of Children, Advisory Opinion OC-17 IACtHR Ser A No 17 (28 August 2002).

49 Other groups in situation of vulnerability identified by the Courts are indigenous people, Afro-descendant populations, the mentally ill who have been institutionalised, undocumented immigrants, rural population displaced from their land and poor people living with HIV/ AIDS.

50 Atala Riffo and Daughters Case IACtHR Ser C No 239 (24 February 2012) para 131. 
Third, the Court emphasises the demanding and active role the state must play in guaranteeing the human rights of victims living under situations of structural inequality and vulnerability. The Court requires the state not only to recognise rights but also to ensure that their holders are in fact protected from third parties' infringements and that institutional, cultural and material conditions necessary for the exercise of those rights are in place. In the Cotton Field case, the Court condemned Mexico for falling below the required standard of due diligence in the protection of the victims, noting the failure of the state's response to the crimes and giving extensive details of the institutional flaws during investigations. Also, the Court found that Mexico did not comply with the affirmative obligation to take all necessary measures to debunk wrongful stereotypes about women and for reinforcing patterns of violence and discrimination against women through the practices of its authorities. In the Atala case, the Court could have limited itself to declare the breach by the Chilean Supreme Court of its obligation to abstain from discriminating Ms Atala in its judgment. However, the Court went further and reminded the State that its human rights obligations are not only negative in kind, but that it is required to take affirmative measures to change cultural demeaning stereotypes against women and sexual minorities that impede the full enjoyment of their human rights.

Finally, the most original and substantive contribution of the Court in advancing a transformative conception of equality has taken place in its decisions regarding the measures of reparations for the victims of human rights violations. The Court has creatively interpreted Article 63(1) of the American Convention ${ }^{51}$ to develop the most comprehensive legal regime on reparations existing in international human rights law. ${ }^{52}$ This regime has been labelled 'victim-centred', due to its clear commitment to meet the victims' needs of recognition, restoration and accountability. ${ }^{53}$ The vast experience of the Court in dealing with gross and systematic violations of human rights early proved that a restrictive focus on declaratory relief and compensation payments for pecuniary and nonpecuniary damages was not enough. In that kind of cases it is impossible to get full restitution to the situation that existed before the violation, and what the family of the victims' most ask for is to know what happened to their loved ones and to be given the opportunity to bury their corpses, to hear an apology

51 Art 63(1): 'If the Court finds that there has been a violation of a right or freedom protected by this Convention, the Court shall rule that the injured party be ensured the enjoyment of his right or freedom that was violated. It shall also rule, if appropriate, that the consequences of the measure or situation that constituted the breach of such right or freedom be remedied and that fair compensation be paid to the injured party'. American Convention on Human Rights (adopted 22 November 1969, entered into force 18 July 1978) OAS Treaty Series No 361144 UNTS 123; reprinted in Basic Documents Pertaining to Human Rights in the Inter-American System OEA/Ser LV/II.82 Doc 6 Rev 1 at 26 (1992).

52 Claudio Grossman, 'Introduction. Reparations in the Inter-American System: A Comparative Approach Conference' (2007) 56 Am UL Rev 1376.

53 Thomas M Antkowiak, 'An Emerging Mandate for International Courts: Victim Centered Remedies and Restorative Justice’ (2011) 47 Stan J Intl L 279. 
from the state, to be able to rebuild their lives and their community bonds, and guarantees that others would not have to suffer from similar crimes in the future. The Court also realised that in those situations it is not possible or realistic to entrust the domestic authorities of the states with the design of the reparation regime and that the Court would have itself to undertake that duty and supervise the state's compliance. ${ }^{54}$ The Court's approach has been one of favouring integral reparations, sensitive to the claims of the victims, and appreciative not only of the individual, but also of the collective dimensions of the harm produced by human rights violations. Most importantly, the focus of the Court has been on addressing, as much as possible, the underlying causes that made the violations possible and in restating or generating legal, institutional and cultural conditions at the domestic level aimed at rehabilitating legal order compatible with the American Convention. ${ }^{55}$

In dealing with current cases of human rights violations and understanding their connection to systemic patterns of exclusion, structural discrimination, pervasive violence and institutional breakdown, the Court has expanded the scope of its reparations, particularly the measures assigned to comply with the guarantee of non repetition, towards the ambitious goal of transforming the preexisting conditions that enable the rights infringements to happen in the first place. When gender discrimination and gender violence is one of such pre-existing conditions, this approach requires nothing less than devising mechanisms aimed at subverting existing oppressive gender hierarchies. ${ }^{56}$ In the Cotton Field and in the Atala cases, the Court declared that when discriminatory acts and violations are related to the perpetuation of stereotypes that are associated with the structural discrimination suffered by particular groups (in these particular cases, women and LGBTI people), reparations cannot consist in reinstating the situation prior to the violation and must seek to transform such pre-existing situation by identifying and eliminating the factors that cause discrimination. ${ }^{57}$ Also the Court said that reparations must have a causal nexus with the facts of the case, the violations declared and the damage verified, ${ }^{58}$ and must be adopted from a gender perspective. ${ }^{59}$ Among other measures, the Court ordered Mexico and Chile to hold public acts of recognition of international responsibility and apology to the victims, with the presence of high rank state authorities, including, in the

\footnotetext{
54 The European Court, on the contrary, defers to the respondent state and the Committee of Ministers, which offers only recommendations as to the reparation measures design and implementation. ibid 320 .

55 Sergio García Ramírez, 'Reparations in the Inter-American System: A Comparative Approach Conference’ (2007) 56 Am ULRev 1433.

56 Ruth Rubio-Marín and Clara Sandoval, 'Engendering the Reparations Jurisprudence of the Inter-American Court of Human Rights: The Promise of the Cotton Field Judgment' (2011) 33 HRQ 1062.

57 González ('Cotton Field') Case IACtHR Ser C No 205 (16 November 2009) para 450; Atala Riffo and Daughters Case IACtHR Ser C No 239 (24 February 2012) para 267.

58 Atala Riffo and Daughters Case IACtHR Ser C No 239 (24 February 2012) para 242.

59 González ('Cotton Field') Case IACtHR Ser C No 205 (16 November 2009) para 450.
} 
Atala case, members of the judiciary. The Mexican State was obliged to broadcast the act honouring the victims on local and federal television and radio and to consult the next of kin regarding the organisation and details of the ceremony. The Court ordered the states to publish the judgments in their websites and in a daily newspaper with widespread circulation, and to provide effective training to public officials and the community on human rights law and non-discrimination, including the very specific training to identify and dismantle wrongful gender stereotypes. In the Cotton Field case, the Court mandated the erection of a monument in memory of the victims of gender violence of Ciudad Juárez. The Court also specified several measures aimed at the investigation of the crimes, and the prosecution and, if appropriate, the punishment of those responsible for them, which should include a gender perspective and involve specific lines of inquiry concerning sexual violence, as well as the creation of a database with genetic and other information that would help in the search for other women disappeared nationwide. The Court extensively reviewed all the legal and institutional reforms and policies Mexico had taken in the years previous to the judgment regarding the prevention of discrimination and violence against women, and made clear that human rights compliance required proof of effectiveness of those reforms and policies, which was absent in the case due to lack of information that should have been provided by the parties. As is common in its judgments, in both cases the Court announced that it would monitor full compliance with the judgments and would consider the case closed when the respective states had complied with all the measures ordered in them.

\section{DEBUNKING GENDER STEREOTYPES THROUGH ADJUDICATION}

Although human rights justice systems are mostly built on a model of individual adjudication, human rights violations usually occur because there are economic, political, institutional and cultural conditions that make them possible, and the victims are individuals or groups in disadvantaged positions within such structural arrangements.

The Inter-American Commission and Court have assertively confronted this reality and used all the powers within their mandates to create and enforce clear human rights standards on several issues and to boost processes of transformation within the states that would change underlying conditions that make people vulnerable to human rights violations. ${ }^{60}$ The Court, particularly through its

60 The Commission's thematic reports are the best example of the creation of human rights standards for the region. Thematic reports dealing with the issue of stereotyping includes: Inter-American Commission on Human Rights, 'Access to Justice for Women Victims of Violence in the Americas' (20 January 2007) OEA/Ser L/V/II Doc 68 <www.cidh.org/ women/Access07/Report\%20Access\%20to\%20Justice\%20Report\%20English\%20020507.pdf> 
decisions on reparations, has ordered the states to reform constitutional ${ }^{61}$ and legal provisions, ${ }^{62}$ to annul criminal sentences, ${ }^{63}$ to restitute traditional lands, ${ }^{64}$ to provide basic public services such as water and education, ${ }^{65}$ to provide human rights training, ${ }^{66}$ among many others. The aim is not only to provide redress to the few victims and cases that make their way to the Court, but also to foster the domestic capacities of the states to prevent and respond to human rights violations.

When the Court identifies discrimination and violence against women as structural conditions and orders transformative measures such as those contained in the Cotton Field and the Atala judgments, the Court is acting on certain assumptions about gender, which it seeks to modify. The gender system is basically a system of beliefs and power mechanisms that maintain and perpetuate those beliefs. The need to expose and eliminate wrongful gender stereotypes is based on the thesis that gender is socially constructed and not natural and that, within that gender system, women are assigned subservient roles and considered as having inferior attributes and characteristics than men. ${ }^{67}$ Subordination and exclusion of women take place through the uncritical application of stereotyped

accessed 5 September 2015; Inter-American Commission on Human Rights, 'Access to maternal health services from a human right perspective' (7 June 2010) OEA/Ser L/V/II Doc 69 <www.oas.org/en/IACmHR /women/docs/pdf/MaternalHealth2010.pdf> accessed 5 September 2015; Inter-American Commission on Human Rights, 'The Road to Substantive Democracy; Women's political participation in the Americas' (18 April 2011) OEA/Ser L/V/ II Doc 79 <www.cidh.oas.org/pdf\%20files/POLITICAL\%20PARTICIPATION.pdf> accessed 5 September 2015; Inter-American Commission on Human Rights, 'The work, education and resources of women: The road to equality in guaranteeing economic, social and cultural rights' (2 November 2011) OEA/Ser L/V/II.143 Doc 59 <www.cidh.oas.org/pdf\%20files/ womendesc2011.pdf> accessed 5 September 2015; Inter-American Commission on Human Rights, 'Legal standards related to gender equality and women's rights in the Inter-American Human Rights System: development and application' (3 November 2011) OEA/Ser L/V/II.143 Doc 60 <www.oas.org/en/IACmHR/women/docs/pdf/REGIONAL\%20STANDARDS.pdf> accessed 5 September 2015; Inter-American Commission on Human Rights, 'The situation of people of African descent in the Americas' (5 December 2011) OEA/Ser L/V/II Doc $62<$ www. cidh.oas.org/pdf\%20files/AFROS\%202011\%20ENG.pdf> accessed 5 September 2015; InterAmerican Commission on Human Rights, 'Access to Justice for Women Victims of Sexual Violence: Education and Health’ (28 December 2011) OEA/Ser L/V/II Doc 65 <www.oas. org/en/IACmHR /women/docs/pdf/sexualviolenceeduchealth.pdf> accessed 5 September 2015; Inter-American Commission on Human Rights, 'Human Rights of Migrants and Other Persons in the Context of Human Mobility in Mexico' (13 December 2013) OEA/Ser L/V/ II Doc 48/13, paras 225 and $485<$ www.oas.org/en/IACmHR/migrants/docs/pdf/ReportMigrants-Mexico-2013.pdf $>$ accessed 5 September 2015.

${ }_{61}$ 'The Last Temptation of Christ' (Olmedo-Bustos) Case IACtHR Ser C No 73 (5 February 2001).

62 Case of Expelled Dominicans and Haitians v Dominican Republic IACtHR SerC No 282 (28 August 2014).

63 Norín Catrimán (Leaders, members and activist of the Mapuche Indigenous People) Case IACtHR SerC No 279 (29 May 2014).

64 Sawhoyamaxa Indigenous Community IACtHR SerC No 146 (29 March 2006) para 210. Ibid para 230.

Atala Riffo and Daughters Case IACtHR SerC No 239 (24 February 2012) paras 271-272. Rebecca Cook and Simone Cusack, Gender Stereotyping: transnational legal perspectives (University of Pennsylvania Press, 2009) 2. 
ideas, symbols and roles. ${ }^{68}$ Stereotypes harm women by devaluing them, limiting their ability to autonomously design their life plans, and by the very concrete impositions of unjust burdens and denial of benefits that are available to men. Sometimes, as the Cotton Field case proves, stereotyping may even lead to murder and impunity. By showing the relationship between gender subordination and violence, the Court considers the hierarchical and exclusionary uses of violence as a disciplinary mechanism to maintain gender hierarchies. ${ }^{69}$

The judicial enforcement of the human rights obligation of states to eliminate wrongful gender stereotypes, an obligation that is contained in the CEDAW ${ }^{70}$ and Belem do Pará ${ }^{71}$ conventions, and is also built into the American Convention by the Court, is a mission of enormous reach and ambition. The Court performs an extraordinarily expressive and educational role when it brings into its decisions the language on stereotypes as it does in the Cotton Field and the Atala cases. That role is brought to its maximum expression when the Court makes the state take actions directed at deconstructing gender and other hierarchies and dignifying the victims it previously dismissed, and particularly, when it obliges state authorities to artificially create symbolic spaces of equality and respect in which the victims or their next of kin are the main protagonists, as it occurs in the ceremonies in which the states officially recognise its human rights violations and present its public apologies to the victims.

However, the mission assumed by the Court of debunking gender stereotypes though adjudication is fraught with difficulties. I will briefly refer to two different challenges the Court has confronted o may confront in the future. I believe each of them deserves more attention by human rights scholars and activists.

\section{SEPARATING THE WHEAT FROM THE CHAFF}

First, the Court must open new grounds in human rights adjudication with little guide on how to deal with stereotypes. Although it is not hard for a judge to appreciate that stereotyping may be unfair to the individual being stereotyped, it is not immediately obvious what is exactly wrong about stereotyping. Stereotypes perform important cognitive functions that help us to make sense of our reality by

\footnotetext{
$68 \quad$ Ibid.

69 María Mercedes Gómez, 'Los Usos Jerárquicos y Excluyentes de la Violencia' in Rodolfo Arango et al (eds), Más allá del Derecho: Justicia y Género en América Latina (Bogotá Siglo del Hombre, Red Alas Los Andes U 2005).

70 Article 5(a) of the Convention on the Elimination of All Forms of Discrimination against Women (adopted to signature 18 December 1979, entered into force 3 September 1981) UN General Assembly resolution 34/180, 34 UN GAOR Supp No 46 at 193 UN Doc A/34/46, 1249 UNTS 13 .

${ }_{71}$ Articles 6(b), 7(e) and 8(b) of the Inter-American Convention on the Prevention, Punishment and Eradication of Violence against Women (adopted 9 June 1994 entered into force 5 March 1995) IACmHR (1994) 33 ILM 1534.
} 
reducing its complexity and by helping to anticipate other people's behaviour. ${ }^{72}$ Most importantly, legal reasoning is only possible if based on generalisations, and individual considerations in adjudication for long has been considered more of a risk to equal rights than a condition for their recognition. The universality and blindness of the law, which inevitably implies grouping individuals into different categories and treating them in the same way is justly represented as a guarantee against judicial arbitrariness and favouritism. Not only generalisation, but also profiling ${ }^{73}$ plays an important role in law and public policy. When time and resources are scarce, it might seem just fair and rational to trust in the probabilistic accuracy of some group categorisation even though one knows that this will mean to treat some members of the group in a way that is not respectful to their individual characteristics, as it happens when we grant voting rights at eighteen years old. So the first challenge for a human rights court is to be able to identify why it is wrong to apply stereotypes when considering a specific situation.

This might prove to be very difficult, as all existing criteria for distinguishing between good and bad stereotyping require a reasoned application that depends very much on the context. Wrongful application of a stereotype does not necessarily depend on its being based on factors with no statistical import in reaching generalisations, because even the operation of statistically accurate stereotypes may be wrongful and result in human rights violations under certain circumstances. For example, an Argentinean Court held that although it is statically true that women are physically weaker than men, this is not an acceptable reason to refuse hiring women whose physique make them competent for the job. ${ }^{74}$ Neither it is completely safe to rely on the difference between hostile and benevolent stereotypes. Although hostile stereotypes are clearly problematic and reflect prejudices or biases that may result in the devaluation, marginalisation and subordination of individuals, benevolent stereotypes can also be detrimental as they perpetuate rigid roles and beliefs that may encroach upon individual autonomy. For example, labour laws enacted to protect women from certain hazards of paid work have the effect of reducing the employment available to women. There is also a close connection between stereotypes and identity. ${ }^{75}$ I develop my own sense of self, and hopefully a sense of self-worth and authenticity, by identifying myself as member of one or more communities and by being recognised as such by the other members of those groups. We recognise the communality of our experiences; see ourselves as sharing some common

\footnotetext{
$72 \quad$ Rebecca Cook and Simone Cusack, Gender Stereotyping: transnational legal perspectives (University of Pennsylvania Press 2009) 14- 20.

73 Frederick Schauer, Profiles, Probabilities and Stereotypes (Harvard University Press Belknap Press 2003).

74 Cámara Nacional de Apelaciones en lo Civil, 'Fundación Mujeres en Igualdad y otro c/ Freddo S. A. s/Amparo' Sala H Buenos Aires 16 de diciembre de $2002<$ www.derechoshumanos.unlp. edu.ar/assets/files/documentos/fallo-fundacion-mujeres-en-igualdad-y-otros-contra-freddosa-sobre-amparo.pdf $>$ accessed 5 September 2015.

75 Anthony Appiah, 'Stereotypes and the Shaping of Identity' (2000) 88 Cal LRev 4.
} 
attributes, practices and, most of all, a common narrative on how we are. But generalisations or stereotypes about particular groups may eventually perform a disciplinary function over some non-conforming members of the group and become oppressive as far as they dictate the self-understanding that its members should have. ${ }^{76}$ Also, members of subordinated groups unconsciously internalise oppressive stereotypes imposed by people who - being outside of the group and trying to distinguish themselves from it - have the social and cultural power to script the identity of 'the other'. ${ }^{7}$ A human rights court should then be able to differentiate between stereotypes that help to build authentic, non-essentialist, and dignified subjectivities from those stereotypes that hinder them. This exercise is likely to be exceedingly complicated for judges who are called to act within the constrained framework of the judicial procedure, with limited knowledge of the cultural and sociological realities behind the cases and whose information on the cases is reduced to what the representatives of the parties bring before the Court.

Secondly, the Court must define the extent and depth of its investigation on stereotypes for a particular case. In doing so, the court must determine what exactly is the court called to do when it identifies the operation of a wrongful stereotype. These definitions require a clear notion of the individual and collective impacts of the decision and of what expressive, preventive and reparatory objectives the court aims to achieve with its judgment. This is especially important regarding the reparatory measures the court orders the state to comply with. The more costly the measures are for the states, the more the states will demand that reparations have a causal nexus with the individual human rights violation and the weaker that nexus looks, the more they will contest the political legitimacy of the court's collective remedies.

Reparations aimed at eradicating wrongful gender stereotyping are typically collective and preventive, and therefore they demand a robust and clear justification from the court. The court must be able to explain the connection between the operation of the stereotype in the case, the individual human rights violation such operation made possible and the way in which the reparatory measure ordered by the court to modify the cultural patterns of conduct based on stereotypes would prevent the repetition of similar human rights violations.

In early cases, the Court failed to identify the gendered nature of some human rights violations, and the stereotypes that played a role in their occurrence. ${ }^{78}$ Moreover, the Court itself wrongfully stereotyped women in some of its judgments. ${ }^{79}$ The Cotton Field and the Atala cases show the impressive progress the Court has made in the last decade. The Court has proven its

\footnotetext{
76 Jennifer Nedelsky, 'Community of Judgment and Human Rights' (2000) Theor Inq in L 1.2.

77 Pierre Bourdieu, La dominación masculina (Editorial Anagrama 2000); Simone De Beauvoir, El segundo sexo (Alicia Martorell tr, Cátedra 1998).

78 Patricia Palacios, 'The Path to Gender Justice in the Inter-American Court of Human Rights' (2007-2008) 17 (2) Tex J WL 227.

79 See Loayza Tamayo Case IACtHR Ser C No 47 (8 March 1998).
} 
understanding of the phenomena of gender discrimination and gender violence and has demonstrated a creative commitment to eradicating cultural practices that contribute to their persistence. However, in some other incursions into the issue of gender stereotyping, the Court has been more hesitant about what to do.

In the case of Artavia Murillo ('In Vitro Fertilization) $v$ Costa Rica, ${ }^{80}$ for example, the Court found indirect gender discrimination due to the differentiated disproportional impacts a ban on in vitro fertilisation had on infertile women in comparison to infertile men owing, in part, to the existence of the stereotype that women must be mothers and the fact that 'motherhood has been assigned to women as an essential part of their gender identity. ${ }^{81}$ However, the Court also named the stereotype affecting infertile men, who felt 'a strong sense of impotence' and 'unmanly' and thus questioned in their gender identity. The Court added that these gender stereotypes are incompatible with international human rights law and that measures must be taken to eliminate them. The Court made clear that it was not validating these stereotypes and only recognised them and defined them in order to describe the disproportionate impact of the interference caused by the state's IVF prohibition. ${ }^{82}$ Besides the fact that the Court did not make clear how gender stereotypes in this case could sustain the Court's indirect gender discrimination assertion given the fact that both women and men were affected in their gender identity, what is interesting about this case is that in order to support its indirect discrimination argument, the Court relied on the existence of wrongful stereotypes. This made the Court feel the need to explain that it was not validating these stereotypes and that they should be eliminated. The uneasiness of the Court comes from the fact that stereotypes in this case appear in a different position than in the Cotton Field or the Atala cases. In the IVF case, the existence of gender stereotypes were not conditions that made possible the infringements of rights. They were conditions that created or increased the suffering of the victims. If women's sense of self worth would not rely on their fertility and men's confidence in their sexual potency, the ban on IVF would not have made the victims felt as miserable as they did. In this case, the Court correctly identified and named the gender stereotypes, ${ }^{83}$ but this was not a case in which the Court could have done something else out of that finding, for example, regarding reparations. Even if, as a result of existing stereotyping, women suffered

\footnotetext{
Artavia Murillo ('In Vitro Fertilization') Case IACtHR Ser C No 257 (28 November 2012).

Ibid para 298.

Ibid para 302.

However, where the Court refers to 'the stereotype that protection of the fetus should prevail over the health of the mother' it makes a mistake in the identification of another stereotype present in the case. The stereotype behind that statement is that women should sacrifice for their (even unborn) children. The inference is that the protection of the fetus is given priority over the right to health of the pregnant woman. Artavia Murillo ('In Vitro Fertilization') Case IACtHR Ser C No 257 (28 November 2012) para 297. See Simone Cusack, 'Eliminating Judicial Stereotyping: Equal Access to Justice for Women in Gender-Based Violence Cases' (Office of the High Commissioner for Human Rights 2014) <www.ohchr.org/Documents/Issues/ Women/WRGS/StudyGenderStereotyping.doc> accessed 5 September 2015.
} 
more than men, and even admitting - as the Court does - that the state has a legal duty to eliminate wrongful gender stereotypes, it still seems that it would be too far-fetched to make the state pay a larger amount of pecuniary damages to the women than to the men exposed to the IVF ban. This makes the Court's incursion into the issue of stereotyping in this case somehow superfluous. In another case, this time against Paraguay, the Court did awarded US \$5,000 more to the mother than to the father of a child that was killed by military forces. In this case the mother had an emotional breakdown during her testimonial hearing before the Court. ${ }^{84}$ However understanding one might be of the empathetic reaction of the members of the Court towards the mother, this is probably an example in which the endorsement of the maternal stereotype by the Court was not only superfluous, but counterproductive and maybe unfair to the father. It reinforced the stereotypical beliefs of women as more dedicated and closer to their children than men, and also as weaker and in greater need of protection than men.

However - and this shows how contextual the analysis on stereotypes should be - there might be cases in which stereotypes that operate to increase the suffering of the victims of human rights violations should be disclosed and even taken into account for the purposes of making the state compensate for such extra suffering. One of such cases is Miguel Castro Castro Prison v Peru. ${ }^{85}$ In this case police and military forces under the political command of former president Fujimori were the perpetrators of atrocious crimes against members of the opposition movement Shining Path who were detained in the Castro Castro prison. There is evidence in the case of their deliberate exploitation of several gender stereotypes to increase the emotional impact of the attacks on the victims and their relatives. As it is common in sexual violence cases in the context of armed conflicts, the attack on women's victims was - at least partly - aimed at humiliating and demoralising the male members of Shining Path who helplessly saw how explosives and heavy artillery were being used against the women's pavilion of the Castro Castro prison, all this during visiting day, before the eyes of the 'mothers, sisters, wives and children'86 of the inmates who had planned to celebrate Peruvian mother's day, and who were at the gates desperately trying to find out what was happening. The women inmates who survived the prison attack were kept under inhuman conditions and subjected to all kinds of assaults, including rape, violent vaginal inspections, forced nudity, and lack of gynaecological care to pregnant women. As stated in the arguments of the common intervener, the captors devised the "offering of a "prize" system to those who "abandoned" their freedom of thought in exchange for "returning them" their femininity giving them access to implements such as comb, lipstick, etc., and to be reintegrated into their role of being a "good mother." Those women who accepted submission could see their

Vargas Areco Case IACtHR Ser C No 155 (26 September 2006).

Miguel Castro Castro Prison Case IACtHR Ser C No 160 (25 November 2006).

Ibid para 197.18. 
children again..$^{87}$ The Court judgment in Castro Castro rightly took into account most of the gender dimensions involved in this case and this was reflected in its decisions on reparation.

The case of Fornerón and Daughter $v$ Argentina ${ }^{88}$ is a different and extremely interesting case. Mr Fornerón was a single father who was consistently denied by the Argentinian courts, first the custody, then visitation rights and finally his right to oppose the adoption of his biological daughter, who had being surrendered by her mother to a married couple upon birth. In this case the Court correctly identified a compound gender stereotype: that single young men are not able to be the primary caretakers of their children, and explained the connection between the operation of the stereotype and the violation to Mr Fornerón's rights to judicial guarantees and judicial protection. However, the Court failed by not realising that this case was also a gender discrimination case against Mr Fornerón, and a violation to the equality provisions of the American Convention.

As in the Atala case, the Argentinian courts' decisions were not based on Mr Fornerón's parental capacities, but on stereotypes. What is interesting about this case is that the Court, by having adopted an anti-subordination theory of equality in previous gender cases, failed this time to find gender discrimination because Mr Fornerón, being a heterosexual man, was not a member of a historically disadvantaged group, like women or sexual minorities. The Court did not make the connection between gender stereotypes and structural discrimination, as it did in Cotton Field and Atala, and for that reason it did not find an infringement of the right to equality and non-discrimination under the American Convention. The Court was short-sighted. Fornerón was a particularly promising case to show how gender stereotyping, by reinforcing a 'separate-spheres' mentality steer men out of traditionally female roles making women to assume those roles. The Court should had remembered that the subordination of women would continue as long as men were required to behave in traditionally masculine ways, and that as long as women's pursuits remained off-limits to men, neither sex would be free from discrimination. ${ }^{89}$

Fornerón is an example of a case in which the Court should have gone further in its inquiry on stereotypes and could have legitimately used the case to educate on the collective impact of gender stereotyping and to impose integral preventive reparatory measures aiming at stopping the state for enforcing sex role stereotypes.

$87 \quad$ Ibid para $260 \mathrm{r}$ ).

88 Fornerón and Daughter Case IACtHR Ser C No 242 (27 April 2012).

89 It was Ruth Bader Ginsburg and her colleagues at the ACLU's Women's Rights Project who decided to challenge the constitutionality of sex-based state action by taking cases with male plaintiffs. Her strategy has recently been revisited and considered as grounded on a theory of equal protection involving constitutional limitations on the state's power to enforce sexrole stereotypes. See Cary Franklin, 'The Anti-Stereotyping Principle in Constitutional Sex Discrimination Law’ (2010) 85 NYU L Rev 83. 


\section{PREPARING FOR BACKLASH}

The Court's approach to gender equality and gender stereotyping is beginning to find significant opposition from influential conservative groups in Latin America. These same groups oppose the regional progressive agenda of legal reforms concerning rights of women and LGBTI people, such as same-sex partnership or same-sex marriage proposals, the recognition of parenting rights to LGBTI couples, bills aimed at legally recognising transgender persons their gender identity, abortion decriminalisation bills, and even general anti-discrimination laws. The conservative opposition to these legal reforms is being articulated in different countries of the Americas through a discourse that attacks what these groups call 'the gender ideology' advanced by 'radical feminists' and 'the gay lobby' in a global crusade to redefine sex, sexuality and human nature, and that is said to endanger the 'natural family' and the 'human rights of children to be raised by a mother and a father. ${ }^{90}$ In Latin America, this conservative discourse on gender issues is not necessarily exclusive of the political right. The criticism against the 'gender ideology' and the agenda for women's and LGBTI people's rights are shared by some left-wing political leaders. ${ }^{91}$

The terms coined and the framing of the arguments are the same as those used by conservative groups in France, Italy, Poland, Belgium, Spain, and other

See in Chile: Hernán Corral, 'No discriminación, transexuales e identidad de género' (Derecho y Academia 2011) <https://corraltalciani.wordpress.com/2011/11/20/no-discriminaciontransexuales-e-identidad-de-genero/> accessed 3 September 2015; Julio Alvear T, 'La Sentencia de la CIDH en el Caso Atala: Una Iniciativa para el Adoctrinamiento en Ideologías Radicales. Notas breves a la sentencia del 24 de febrero de 2012' (2012) 13(26) Revista Actualidad Jurídica 577 <www.academia.edu/3652709/Julio_Alvear._Critica_Corte_IDH_Caso_Atala> accessed 3 September 2015; Max Silva Abbott, 'Algunas Consideraciones sobre la Penetración del Derecho Internacional en los Ordenamientos Estatales Influido por la Perspectiva de Género' (2012) 21 Díkaion $385<$ http://dikaion.unisabana.edu.co/index.php/dikaion/article/ download/2921/3065> accessed 3 September 2015; Hernán Corral, 'Madre hay una sola' (Derecho y Academia 2013) <https://corraltalciani.wordpress.com/2013/04/21/madre-hayuna-sola/> accessed 3 September 2015; Álvaro Ferrer, 'Proyecto de ley de ideología de género: atentado contra la identidad' (Chile B 24 April 2014) <www.chileb.cl/perspectiva/proyectode-ley-de-ideologia-de-genero-atentado-contra-la-identidad/> accessed 3 September 2015; Álvaro Ferrer, 'Chile 'se está cayendo a pedazos; por un tsunami llamado ideología de género' (Porta Luz 9 May 2014) <www.portaluz.org/chile-se-esta-cayendo-a-pedazos-alerta-eldestacado-jurista-alvaro-572.htm>accessed 3 September 2015. See in Argentina: Gabriel Cortina, 'La Ideología de Género, por Jorge Scala' El Diario Exterior (7 June 2010) <www. eldiarioexterior.com/la-ideologia-de-genero-por-38219.htm> accessed 3 September 2015; See in México: Beatriz Campillo, 'Un acercamiento a la ideología de género' (Universidad Pontificia Bolivariana) <http://oeticapoliticaysociedad.medellin.upb.edu.co/index.php/areasde-trabajo/bioetica-y-bioderecho/item/16-un-acercamiento-a-la-ideologia-de-genero.html> accessed 3 September 2015. In Peru: 'Peru, próximo objetivo de la ideología de género en Latinoamérica' (Forum Lebitas 7 September 2013) <www.forumlibertas.com/frontend/ forumlibertas/noticia.php?id_noticia=27269> accessed 3 September 2015.

91 'Ecuador: Correa rechaza ideología de género y afirma que defender la familia es cuestión moral' Aciprensa (Quito, 3 January 2014) <https://www.aciprensa.com/noticias/ecuadorcorrea-rechaza-ideologia-de-genero-y-afirma-que-defender-la-familia-es-cuestion-moral37571/> accessed 3 September 2015. 
European countries, ${ }^{92}$ and their common and primary intellectual source is a collection of multidisciplinary essays published by the Pontifical Council for the Family, called Lexicon: Ambiguous and Debatable Terms Regarding Family Life and Ethical Questions. ${ }^{93}$ According to the Preface to the Lexicon, written by Cardinal Alfonso López Trujillo, President of the Pontifical Council for the Family, the authors 'seek to enlighten people on some ambiguous or confusing terms and jargon difficult to assess.' It explains that these expressions are 'used in parliaments and world forums' and 'exploit the uninformed people who use them and, since they are deceived by their ambiguity, they are not aware of the deception. ${ }^{\text {'94 }}$ Some of the topics covered by the Lexicon are: 'An ideology of gender: dangers and scope', 'Contraceptive mentality', 'Discrimination against women and CEDAW', 'Homosexual marriage', 'Motherhood and feminism', 'New definitions of gender', 'Sexual and reproductive rights' and 'Sexual identity and difference.'

The concept of 'gender ideology' appeared in the aftermath of the United Nations conferences in Cairo in 1994 and Beijing in 1995, which marked the international recognition of sexual and reproductive rights and have set the agenda of international human rights organisations, governments and human rights NGOs regarding women's rights. ${ }^{95}$ The Lexicon publication and its translation to different languages can be read as reaction to confront the advances of the 'gender ideology' at the global level. Although most of the conservative criticism has been directed to the United Nations Human Rights System and the European Union Parliament, now that the Inter-American Court is developing a more robust jurisprudence on women rights and beginning to consider LGBTI people's rights in the inter-American human rights system, the arguments about the Court's unwelcome and dangerous attention to 'the gender ideology' and the 'gay lobby' are also emerging in conservative critical reviews of the Court's decisions. ${ }^{96}$

In conservative arguments, gender is either an unnecessary and dangerous concept that there is no reason to include in the discussions or the texts of legal reforms, or it is re-defined to mean something completely different than the idea

$92 \quad$ David Paternotte, 'Christian Trouble: The Catholic Church and the Subversion of Gender' (Council for European Studies, 8 May 2014) <http://councilforeuropeanstudies.org/critcom/ Christian-trouble-the-catholic-church-and-the-subversion-of-gender/> accessed 3 September 2015; Sara Garbagnoli, 'L'ideologia del genere': l'irresistibile ascesa di un'invenzione retorica vaticana contro la denaturalizzazione dell'ordine sessuale' (2014) 3 About Gender 250.

93 Consejo Pontificio para la Familia, Lexicón: términos ambiguos y discutidos sobre familia, vida $y$ cuestiones éticas ( $3^{\text {rd }}$ edn, Ediciones Palabra 2007).

94 Alfonso Card. López Trujillo, 'Prefacio' in Consejo Pontificio para la Familia, Lexicón. Términos ambiguos y discutidos sobre familia, vida y cuestiones éticas ( $3^{\text {rd }}$ edn, Ediciones Palabra 2007) 7-16.

95 Doris Buss and Didi Herman, Globalizing Family Values: The Christian Right in International Politics (University of Minnesota Press 2003.

96 Julio Alvear T, 'La Sentencia de la CIDH en el Caso Atala: Una Iniciativa para el Adoctrinamiento en Ideologías Radicales. Notas breves a la sentencia del 24 de febrero de 2012' (2012) 13(26) Revista Actualidad Jurídica 577. 
that our social and cultural beliefs on femininity and masculinity are not natural but historically and socially constructed. In the Lexicon, gender is defined as a transcendental dimension of human sexuality, which incorporates the body, the mind and the soul, and that, though changeable, must obey the natural order fixed by the body. ${ }^{97}$ When the strategy used is to redefine gender (or other concepts such as those covered in the Lexicon), efforts are made for the new definitions to be included in legal documents as an interpretative tool in the application of laws and policies regarding women or LGBTI people..$^{98}$

As Paternotte explains, the 'gender ideology' label neither designates the body of work produced by gender studies scholars of various disciplines, nor acknowledges the differences and debates within gender and sexuality studies and the complex interplay between activism and the academy. ${ }^{99}$ It is basically a term created to oppose women's and LGBTI rights activism and to react against the critical edge of gender as an analytical category that deconstructs common naturalistic assumptions about differences between sexes and social relationships based on those differences, and reveals relationships of power involved in gender representations. The term 'gender ideology' amalgams, reduces and conflates many different theoretical proposals and very diverse women's and LGBTI demands and agendas into radical slogans that usually borrows from Judith Butler's work. ${ }^{100}$

Among the alleged evil consequences of the 'gender ideology', that results from its destruction of sex differences and the disrespect of the nature of human being as man and woman are war between sexes, the devaluation of motherhood, promotion of contraception and abortion, acceptance of homosexual partnerships and parentage, and the decline of marriage. ${ }^{101}$ This disregard of the natural order would result, according to Benedict XVI, in 'the self-destruction of man himself, and hence, the destruction of God's own work.'102

Although it is more than fanciful to see the Court - and any international human rights body so far - as advancing anything like a 'gender ideology' - let

${ }_{97} \quad$ Beatriz Vollmer de Colles, 'Nuevas definiciones de género' in Consejo Pontificio para la Familia, Lexicón. Términos ambiguos y discutidos sobre familia, vida y cuestiones éticas ( $3^{\text {rd }}$ edn, Ediciones Palabra 2007) 835.

98 The following is a proposal for a definition of gender made by the Unión Demócrata Independiente, a Chilean conservative right-wing party, which asks it to be included in the statute that created the Ministry of Women's Affairs in Chile: 'For the purpose of this law, gender is a cultural expression, which changes according to historical and social circumstances, of those aspects and characteristics that are naturally constituted by the genetic, hormonal, morphological, psychological, emotional, cognitive and behavioral of a person, as differentiated as a man or a woman.'

100 Ibid.

101 Tony Anatrella, 'Caritas in Veritate, La famille et la théorie du genre', Speech at SECAM (the Symposium of Episcopal Conferences of Africa and Madagascar) in Accra, Ghana (31 July 2010), cited by Mary Anne Case, 'After Gender the Destruction of Man - The Vatican's Nightmare Vision of the "Gender Agenda” for Law' (2011) 31 Pace L Rev 805. 
alone Butler's queer theory! - it must be admitted that there are real and significant differences between the conservative positions in their present form and the Court's approach to gender equality and stereotypes. The Court does believe that social attributes and opportunities associated with being male and female and the relationships between women and men are learned through socialisation processes and that in most societies gender norms produce inequalities between women and men in the responsibilities assigned, control over resources and decision-making opportunities. ${ }^{103}$ And the Court has shown its commitment to enforce human rights obligations to eliminate wrongful gender stereotypes that impede women and LGBTI the full and equal enjoyment of their human rights. This is not acceptable to conservative critics who believe that traditional gender roles are intrinsically linked to the different identities of men and women and that measures to debunk gender stereotypes result in the trivialisation of sexual specificity.

These paragraphs about the opposition the Court is beginning to confront and which will likely increase in time, are justified because, within the inter-American system, the conservative reaction will be more intense and bitter than it has been in the UN or the European Union, given the greater influence and political power the Catholic Church has in Latin American countries, and the fact that, unlike what happens in those other international forums, in the inter-American system cautious diplomatic manners and practices that are typical of big bureaucratic international and multicultural institutions, and that play an important buffer role in conflicting negotiations, are not yet sufficiently developed.

The Court should be aware and forewarned about this coming opposition, and understand that what these documents call 'the gender ideology' by no means represents the Court's or other international human rights' organs standing on gender equality. The Court must rely on the valuable global expertise and experience the international and regional human rights systems have acquired through decades of confronting different kinds of inequalities and discriminations happening in different settings and cultures. One lesson that I think can be safely drawn from that experience is that appeals to culture,

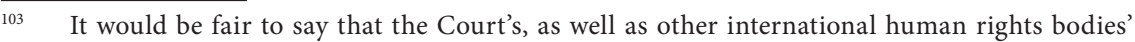
understanding of gender is consistent with the definition given by UN Women, the United Nations Entity for Gender Equality and the Empowerment of Women, which states that 'gender refers to the social attributes and opportunities associated with being male and female and the relationships between women and men and girls and boys, as well as the relations between women and those between men. These attributes, opportunities and relationships are socially constructed and are learned through socialisation processes. They are context/time-specific and changeable. Gender determines what is expected, allowed and valued in a women or a man in a given context. In most societies there are differences and inequalities between women and men in responsibilities assigned, activities undertaken, access to and control over resources, as well as decision-making opportunities. Gender is part of the broader socio-cultural context. Other important criteria for socio-cultural analysis include class, race, poverty level, ethnic group and age.' 'Concepts and definitions' (UN Women) <www.un.org/womenwatch/osagi/ conceptsandefinitions.htm> accessed 3 September 2015. 
religion and science to justify difference of treatment between individuals and groups many times serve the purpose of rationalising prejudice and of legitimising existing power relationships. Another is that reducing intolerance and discrimination through judicial adjudication is a slow and difficult process that requires deep understanding of the arguments opposing legal changes, and a rigorous justification of all decisions made in pursuit of equality. 



\title{
'MY SENSE OF HUMANITY HAS GONE DOWN THE DRAIN'
}

\author{
Stereotypes, Stigma and Sanism
}

\author{
Michael PERLIN
}

It is impossible to meaningfully consider the power of stereotypes in mental disability law without considering the pernicious power of 'sanism': an irrational prejudice of the same quality and character of other irrational prejudices that cause and are reflected in prevailing social attitudes of racism, sexism, homophobia and ethnic bigotry. ${ }^{1}$ Sanism ${ }^{2}$ pervades and infects every area of mental disability law, be it civil or criminal, ${ }^{3}$ or domestic or international. ${ }^{4}$ Based on stereotypes and stigma, it explains our laws and our court rulings on commitment law, right to treatment law, right to refuse treatment law, deinstitutionalisation law, antidiscrimination law, the whole range of criminal law issues, from competency determinations to the insanity defence to sentencing to the death penalty, and to such important meta-issues as adequacy of counsel. In the context of international human rights law, sanism is also the key to the way that mental disability law is (or is not) applied worldwide, a factor that has grown since the ratification of the UN Convention on the Rights of Persons with Disabilities (CRPD). ${ }^{5}$

See eg Michael L Perlin, 'On “Sanism”' (1992) 46 SMUL Rev 373.

The word 'sanism' was, to the best of my knowledge, coined by Dr Morton Birnbaum. See Morton Birnbaum, 'The Right to Treatment: Some Comments on its Development' in Frank Ayed (ed), Medical, Moral and Legal Issues in Health Care (Williams \& Wilkins 1974), discussed in this context in Michael L Perlin, 'The Deinstitutionalization Myths: Old Wine in New Bottles' in Karl Menninger and Heather Watts (eds), The Second National Conference on the Legal Rights of the Mentally Disabled (Kansas Bar Associations 1979) Conf Rep.

3 See eg Michael L Perlin, The Hidden Prejudice: Mental Disability on Trial (American Psychological Press 2000); Michael L Perlin, A Prescription for Dignity: Rethinking Criminal Justice and Mental Disability Law (Ashgate 2013).

$4 \quad$ See eg Michael L Perlin, International Human Rights and Mental Disability Law: When the Silenced Are Heard (OUP 2011).

5 See generally, ibid. See also Michael L Perlin, “"A Change Is Gonna Come”: The Implications of the United Nations Convention on the Rights of Persons with Disabilities for the Domestic Practice of Constitutional Mental Disability Law' (2009) 29 No Ill U L Rev 483. 
There are seven major points to be considered in the context of stereotyping and human rights law in the context of persons with mental disabilities:

(1) Stereotypes, by typifying in negative ways, especially in their implicit (and sometimes explicit ways of characterising certain persons as 'less than human'), necessarily limit the enjoyment of human rights.

(2) Because persons with mental disabilities are regularly dehumanised, they are frequently treated in the courtroom in ways that do not comport with dignity.

(3) Whenever an anti-discrimination law is proposed, these invidiousness stereotypes emerge, and inevitably alter and infect the ensuing debate. Often, the resulting laws reflect this.

(4) We have done an extraordinarily poor job of answering the question that has bedevilled civil rights activists since the 1950s: how to capture 'the hearts and minds' of the public so as to best insure that statutorily and judicially articulated rights are incorporated - freely and willingly - into the day-today fabric and psyche of society?

(5) Litigators should aggressively and affirmatively take test cases that involve such stereotypes to the regional courts/commissions on human rights, so as to seek explicit pronouncements that official perpetuation of such stereotypes violates international human rights law.

(6) Advocates working with and on behalf of persons with mental disabilities must follow strategies effectively employed in cases involving racial, genderbased, and gender preference-based stereotypes both in terms of litigation and in terms of raising public awareness.

(7) It is essential that all participants in this system take seriously the CRPD, and begin to employ it in litigation, in local domestic legislative debates, and in the public arena to best combat these stereotypes.

In considering each of these points, it is also essential to assess the importance of therapeutic jurisprudence as a potentially remediative tool in this area of law and policy.

In 1997, Bob Dylan released an album, Time Out of Mind, widely seen as his best piece of work in over two decades. One of the stunning songs on that album, Not Dark Yet, suggested to the listener that it was almost a valedictory for Dylan as he saw the end of his career near, ${ }^{6}$ beginning as it does:

Shadows are falling and I've been here all day

It's too hot to sleep, time is running away

As it turns out, that was not so; Dylan has continued to record, and his 2012 album, Tempest, is widely considered to be one of the greatest of his five decade career. See eg Ann Margaret Daniel, 'Bob Dylan's Near Perfect Storm' <www.hotpress.com/9102928.htm> accessed 8 November 2013 (characterising album as 'breathtaking, mythmaking, heartbreaking'). 
Elsewhere in the song, Dylan sings:

Well, my sense of humanity has gone down the drain

Behind every beautiful thing there's been some kind of pain. ${ }^{7}$

A thoughtful analysis of this song suggests that it focuses on how 'the darkest moment ... leads the way towards light.' ${ }^{8}$ This line is relevant in this context because our lazy, unthinking use of the stereotypes we employ when we write, think, talk and decide cases about persons with mental disabilities reflects how our sense of humanity has 'gone down the drain,' but that, if we consider these issues seriously, it may lead us 'towards light.' It is hoped that this chapter - vide Dylan - helps in efforts to seek remediation.

\section{HOW STEREOTYPES LIMIT HUMAN RIGHTS}

First, consider the use of stereotypes in the law. The Americans with Disabilities Act stresses the pernicious role of stereotypes in disability discrimination:

Individuals with disabilities are a discrete and insular minority who have been faced with restrictions and limitations, subjected to a history of purposeful unequal treatment, and relegated to a position of political powerlessness in our society, based on characteristics that are beyond the control of such individuals and resulting from stereotypic assumptions not truly indicative of the individual ability of such individuals to participate in, and contribute to, society. ${ }^{9}$

In construing laws affecting family leave policies, the Supreme Court has stressed that 'the impact of the discrimination targeted by the [Family Medical Leave Act], which is based on mutually reinforcing stereotypes that only women are responsible for family caregiving and that men lack domestic responsibilities, is significant, ${ }^{\prime 10}$ and that such mutually reinforcing stereotypes created a selffulfilling cycle of discrimination that forced women to continue to assume the role of primary family caregiver, and fostered employers' stereotypical views about women's commitment to work and their value as employees.'11

\footnotetext{
See <www.bobdylancom/us/songs/not-dark-yet $>$.

See Tony Atwood, 'Untold Dylan' (10 November 2008) <http://bob-dylanorg.uk/archives/12> accessed 8 November 2013.

42 US C $\$ 12101(a)(7)$ (emphasis added).

Nevada Dept of Human Resources $v$ Hibbs, 538 US 721, 722 (2003).

Ibid 736. See also, ibid: Stereotypes about women's domestic roles are reinforced by parallel stereotypes presuming a lack of domestic responsibilities for men Because employers continued to regard the family as the woman's domain, they often denied men similar accommodations or discouraged them from taking leave. Hibbs is discussed favourably in
} 
Although it has been suggested that there are positive as well as negative stereotypes - that, for instance, 'stereotyping can, for example, be a useful tool to help process the social complexity of the world'12 - these may be pernicious as well. By way of example, people who hold positive stereotypes of Asian Americans see little evidence of discrimination against them. ${ }^{13}$ By way of example, a purportedly " "positive stereotype" about gay men - that they allegedly have good fashion sense or are more sensitive [-] often comes with the implied codicils that they are superficial and flighty or not tough enough in business.' ${ }^{14}$

Stereotyping is especially pernicious when applied to persons with disabilities, and there is no evidence of any 'positive' stereotyping with regard to this population. We would do well to heed the admonition of Judge David Bazelon over forty years ago: that we need to be vigilant about not 'overgeneraliz[ing] about citizens whom it is easy to overgeneralize about.' ${ }^{15}$

Ten stereotypes are commonly applied; ${ }^{16}$ this is the first one:

Mentally ill individuals are 'different,' and, perhaps, less than human. They are erratic, deviant, morally weak, sexually uncontrollable, emotionally unstable, superstitious, lazy, ignorant and demonstrate a primitive morality. They lack the capacity to show love or affection. They smell different from 'normal' individuals, and are somehow worth less. ${ }^{17}$

this context in Reva Siegel, 'You've Come a Long Way, Baby: Rehnquist's New Approach to Pregnancy Discrimination in Hibbs' (2006) 58 Stan L Rev 1871, 88.

12 Simone Cusack and Rebecca Cook, 'Stereotyping Women in the Health Sector: Lessons from CEDAW’ (2009) 16 Wash \& Lee J Civil Rts \& Soc Just 47, 51.

13 Miranda Oshige McGowan and James Lindgren, 'Testing the "Model Minority Myth"' (2006) 100 NwUL Rev 331, 333. See also, in a very different context, Debra Lyn Bassett, 'The Rural Venue' (2006) 57 Ala L Rev 941, 960 ('positive stereotypes found in land use laws are often circular and conclusory').

14 Todd Brower, 'Pride and Prejudice: Results of an Empirical Study of Sexual Orientation Fairness in the Courts of England and Wales' (2005-06) 13 Buff Women's LJ 17, 75-76. See also, ibid: 'Moreover, whether stereotypes are good or bad, they often underline social difference as they countenance a view of people by reference to group features, and not as individuals. Although majority group stereotypes exist, people rarely take them seriously as a shared characteristic, but as something that applies to only some persons'.

15 David Bazelon, 'Institutionalization, Deinstitutionalization, and the Adversary Process' (1975) 75 Colum L Rev 897, 909, as quoted in Michael L Perlin and John Douard, 'Equality, I Spoke That Word/As If a Wedding Vow: Mental Disability Law and How We Treat Marginalized Persons' (2008-09) 53 NYLSchLRev 9, 26.

16 See eg Perlin (n 1) 393-397 (other stereotypes relate, inter alia, to presumptive and inherent danger, presumptive incompetency, ease of identification, need for segregation, acceptability of using pejorative language in descriptions, and inherent laziness).

$17 \quad$ See eg Perlin (n 1) 393; see also eg Michael L Perlin, 'Everybody Is Making Love/Or Else Expecting Rain: Considering the Sexual Autonomy Rights of Persons Institutionalized Because of Mental Disability in Forensic Hospitals and in Asia' (2008) 83 Wash L Rev 481, 503. On how conflicting stereotypes are employed in the matter of sexuality and persons with psychiatric disabilities, see Michael L Perlin and Alison J Lynch, "'All His Sexless Patients": Persons with Mental Disabilities and the Competence to Have Sex' (2014) 89 Wash L Rev 257, 298: '[Legislative] policies flowed, in large part, from two contradictory stereotypes: one of infantilization (denying the reality that institutionalized persons with disabilities may retain the same sort of sexual urges, desires, and needs the rest of us have and generally upon 
Persons institutionalised in psychiatric hospitals are often treated as less than human, and the conditions of their confinement sometimes leads them to think of themselves as 'less than human. ${ }^{18}$ As recently as 1960, a state Supreme Court rejected the notion that the Due Process clause applied to this population: '[the patient's] loss of liberty is not such liberty as is within the meaning of the constitutional provision that "no person shall be deprived of life, liberty or property without due process of law."'19 Even today, in court proceedings across the United States, 'persons with mental disabilities are regularly treated as thirdclass citizens by (at the best) bored or (at the worst) malevolent trial judges. ${ }^{20}$ The treatment of these individuals as 'less than human' continues even after death. ${ }^{21}$

Interestingly, even traditional human rights NGOs have taken similar positions, rejecting the notion that the rights of persons with mental disabilities are worth their attention. ${ }^{22}$ As Aaron Dhir has noted, '[f]or decades, the rights of mentally disabled persons were virtually ignored by the human rights movement. ${ }^{23}$ Adds Anna Lawson, '[t]raditionally, disability has not been regarded as a human rights issue. ${ }^{.24}$

which the rest of us act) and, paradoxically, one of demonization (expressing fear of their hypersexuality and the correlative need of protections and limitations to best stop them from acting on these primitive urges).'

18 Renee Gruber, 'A Civil Prison - Fear or Reason? Unbiased Reform of Involuntary Commitment Proceedings for Non-Criminals Admitted into Mental Facilities' (2013) 90 U Det Mercy L Rev 203, 217 (' the experience of having once been a mental patient teaches you to think of yourself as less than human'), quoting Mental Patients' Liberation: Why? How?, Antipsychiatry.org (1970) <www.antipsychiatry.org/mplib.htm> accessed 8 November 2013.

19 Prochaska $v$ Brinegar, 102 NW 2d 870, 872 (Iowa 1960).

20 Michael L Perlin, “There Are No Trials Inside the Gates of Eden”: Mental Health Courts, the Convention on the Rights of Persons with Disabilities, Dignity, and the Promise of Therapeutic Jurisprudence' in Bernadette McSherry and Ian Freckelton (eds), Coercive Care: Law and Policy (Routledge 2013) 193, 209.

${ }^{21} \quad$ See Perlin (n 1) 393 n 144: 'For a stark example of difference in the way mentally disabled persons are treated, even after death, see eg Joan Gallen, 'Mental Patients Finally Put to Rest With Dignity' (The News Tribune NJ) 10 October 1991 (nearly 1,000 patients buried on New Jersey state hospital grounds in unmarked graves); David Corcoran, 'Graves Without Names for the Forgotten Mentally Retarded’ NY Times, 9 December 1991, B6 (850 residents of New York state school for mentally retarded similarly buried).

22 Symposium Transcript, 'The Application of International Human Rights Law to Institutional Mental Disability Law' (2002) 21 NYL Sch J Intl \& Comp L 387, 391 (Comments of Eric Rosenthal, head of Disability Rights International [then, Mental Disability Rights International, then and now, the most prominent US-based NGO in this area of law and policy): 'I began my research ... by examining the human rights studies of non-governmental organizations such as Human Rights Watch and Amnesty International I also looked at the US Department of State's Country Reports on Human Rights Practices. What I found is shocking: those human rights organizations and human rights reports criticized governments when political dissidents were put in psychiatric facilities, but they did not speak out about the abuses against other people who may or may not have mental disabilities.' See also Krasimir Kanev, 'State, Human Rights, and Mental Health in Bulgaria' (2002) 21 NYL Sch J Intl \& Comp L 435, 435 (Amnesty International first involved itself in this issue in Bulgaria in 2001).

23 Aaron Dhir, 'Relationships of Force: Reflections on Law, Psychiatry, and Human Rights' (2008) 25 Windsor Rev L \& Soc Issues 103, 105.

24 Anna Lawson, 'Disability, Degradation, and Dignity: The Role of Article 3 of the European Convention on Human Rights' (2006) 56 NIreLQ 462, 462. 
The use of stereotypes perpetuates stigma. And, in many ways sanism is more pernicious than other stereotypes because it is engaged in by many who would (appropriately) take quick umbrage at the use of stereotypes about other marginalised groups. ${ }^{25}$ Because we unthinkingly consider persons with mental disabilities to be 'less than human', we can comfortably take refuge in the reductive stereotypes of stigmatising sanism. What is especially troubling here is that these stereotypes are employed not solely by lay people (and the popular press) but by judges and the very lawyers assigned to represent this population. ${ }^{26}$ Sanist lawyers trivialise both their clients' problems and the importance of any eventual solution to these problems, and implicitly and explicitly question their clients' competence and credibility, a move that significantly impairs the lawyers' advocacy efforts. ${ }^{27}$ Sanist judges reflect and project the conventional morality of the community; 'judicial decisions in all areas of mental disability law continue to reflect and perpetuate sanist stereotypes'.

The pervasiveness of sanism infects all aspects of the legal process and of life. We cannot make any meaningful progress in coping with stigmatic stereotypes until we come to grips with this.

\subsection{LACK OF DIGNITY ${ }^{28}$}

For the purposes of this discussion, dignity means that people 'possess an intrinsic worth that should be recognized and respected', and that they should not be subjected to treatment by the state that is inconsistent with that intrinsic worth. ${ }^{29}$ Treating people with dignity and respect makes them more likely to view procedures as fair and the motives behind law enforcement's actions as

$25 \quad$ See Perlin (n 1) 373: "Imagine the uproar if a published appellate court decision in 1974 referred to an adult person of colour as a "boy." Imagine the fallout if the New York Times stated in 1964 that Plessy $v$ Ferguson was the lead case on the question of "separate but equal" accommodations. Imagine if, ten years after Roe $v$ Wade, a Congressman had been complimented for his "thoughtful" remarks when he stated that, not only was it still legal to criminalise first-trimester abortions, but that a state could also lawfully bar all women from using contraception Imagine if left-liberal candidates in one of the most progressive legislative districts in the country ran for office on a platform of excluding racial minorities from living in that district.' These acts would quickly, and correctly, be labelled either as racist, sexist or bizarre, and would be decried by well-meaning citizens at virtually all points on the political spectrum. Yet, when we substitute 'mentally disabled person' for 'person of colour' or 'racial minority' or 'woman', we let such acts pass without notice or comment.

26 See Perlin, 'The Hidden Prejudice' (n 3) 51-55 (discussing sanist judges).

27 See Michael L Perlin, “'Simplify You, Classify You”: Stigma, Stereotypes and Civil Rights in Disability Classification Systems’ (2009) 25 GaStULRev 607, 622.

28 This section is generally adapted from Michael L Perlin, “The Judge, He Cast His Robe Aside”: Mental Health Courts, Dignity and Due Process' (2013) 3 Ment Health L \& Pol'y 1.

29 Carol Sanger, 'Decisional Dignity: Teenage Abortion, Bypass Hearings, and the Misuse of Law' (2009) 18 Colum J Gender \& L 409, 415. 
well meaning. ${ }^{30}$ What individuals want most is a process that allows them to participate, seeks to merit their trust, and treats them with dignity and respect. ${ }^{\text {'31 }}$ All concepts of human rights have their basis in some understanding of human dignity. ${ }^{32}$ Dignity has been characterised as one of 'those very great political values that defines our constitutional morality. ${ }^{33}$

The legal process upholds human dignity by allowing the litigant to tell his or her own story. ${ }^{34}$ A notion of individual dignity, 'generally articulated through concepts of autonomy, respect, equality, and freedom from undue government interference, was at the heart of a jurisprudential and moral outlook that resulted in the reform, not only of criminal procedure, but of the various institutions more or less directly linked with the criminal justice system, including juvenile courts, prisons, and mental institutions. ${ }^{35}$ Fair process norms such as the right to counsel 'operate as substantive and procedural restraints on state power to ensure that the individual suspect is treated with dignity and respect.' ${ }^{36}$ Dignity concepts are expansive; a Canadian Supreme Court case has declared that disenfranchisement of incarcerated persons violated their dignity interests. ${ }^{37}$ By way of example, 'the moral dignity of the criminal process would be frustrated if grossly incompetent defendants were permitted to plead guilty. ${ }^{38}$ One of the critical functions of counsel is to 'protect the dignity and autonomy of a person on trial. ${ }^{39}$ Perhaps

30 Tamar R Birckhead, 'Toward a Theory of Procedural Justice for Juveniles' (2009) 57 Buff L Rev 1447, 1474.

31 Luther Munford, 'The Peacemaker Test: Designing Legal Rights to Reduce Legal Warfare' (2007) 12 HarvNegot L Rev 377, 393.

32 Buddhism and Human Dignity, SGI Q (July 2000) Soka Gakkai International <www.sgi.org/ buddhism/buddhist-concepts/buddhism-and-human-dignity.html $>$ accessed 8 November 2013.

33 William A Parent, 'Constitutional Values and Human Dignity' in Michael J Meyer and William A Parent (eds), The Constitution of Rights: Human Dignity and American Values (Cornell University Press 1992) 47, 71.

34 Katherine Kruse, 'The Human Dignity of Clients' (2008) 93 Cornell L Rev 1343, 1353.

35 Eric Miller, 'Embracing Addiction: Drug Courts and the False Promise of Judicial Interventionism' (2004) 65 Ohio St LJ 1479, 1569 (n 463).

36 Peter Arenella, 'Rethinking the Functions of Criminal Procedure: The Warren and Burger Courts' Competing Ideologies' (1983) 72 Geo LJ 185, 200.

37 Sauvé v Canada, [2002] 3 SCR 519, discussed in this context in Michael Pinard, 'Collateral Consequences of Criminal Convictions: Confronting Issues of Race and Dignity' (2010) 85 NYU L Rev 457, 464.

38 Bruce J Winick, 'Reforming Incompetency to Stand Trial and Plead Guilty: A Restated Proposal and a Response to Professor Bonnie' (1995) 85 J Crim. L \& Criminology 571, 593. But compare Michael L Perlin, “Dignity Was the First to Leave”: Godinez v Moran, Colin Ferguson, and the Trial of Mentally Disabled Criminal Defendants' (1996) 14 Behav Sci \& L 61 (critiquing the US Supreme Court's decision in Godinez v Moran, 509 US 389 (1993) (setting standard for competence to plead guilty same as for competence to stand trial) as robbing the legal process of dignity.

39 Jones $v$ Barnes, 463 US 745, 759 (1983) (Brennan, J, dissenting). See also eg Philip Halpern, 'Government intrusion into the attorney-client relationship: an interest analysis of rights and remedies' (1983) 32 Buff L Rev 127, 172 ('the right to counsel embraces two separate interests: reliable and fair determinations in criminal proceedings, and treatment of defendants with dignity and respect regardless of the effect on the outcome of criminal proceedings'). 
counterintuitively to much of the lay public, dignity may trump 'truth' as a core value of the criminal justice system. ${ }^{40}$

By engaging in stigmatic stereotypes, we rob persons with mental disabilities of their dignity, often shaming and humiliating them in the process. ${ }^{41}$ It is essential that dignity be present in all aspects of the legal process in matters involving persons with mental disabilities. ${ }^{42}$ The absence of dignity allows/encourages stigma and stereotypes to fester and grow, unchallenged. Sanist thinking makes it highly unlikely that the legal process will reflect 'dignity' values; ${ }^{43}$ it is essential that such thinking be eradicated from this process.

\subsection{STEREOTYPES CONTAMINATE LEGISLATIVE DEBATE ${ }^{44}$}

A reading of legislative debate over non-discrimination laws reveals the extensive use of stereotypes by opponents of the laws. Consider first the Americans with Disabilities Act. ${ }^{45}$ A reading of the legislative history, the early commentaries and even the practice manuals barely acknowledges the application of the ADA to persons with a mental disability. ${ }^{46}$ When enacting the ADA, Congress appeared to treat mental disability issues as a 'poor stepchild' to matters dealing with physical disability. ${ }^{47}$ There was little legislative debate, and what there was suggested a 'fairly wide gap' between Congress' concerns in writing the legislation, and the

40 Erik Luna and Paul G. Cassell, 'Mandatory Minimalism' (2010) 32 Cardozo L Rev 1, 52. On the application of human dignity principles to limit the scope of criminalisation of victimless crimes (specifically, drug offences) see generally, Michal Buchhandler-Raphael, 'Drugs, Dignity, and Danger: Human Dignity as a Constitutional Constraint to Limit Overcriminalization' (2013) 80 Tenn L Rev 291.

41 See Michael L Perlin and Naomi Weinstein, "Friend to the Martyr, a Friend to the Woman of Shame”: Thinking About the Law, Shame and Humiliation' (2014) So Cal Rev L \& Socl Just (forthcoming).

42 See eg Perlin, Dignity (n 3); Perlin (n 17); Perlin (n 20); Perlin (n 28); Michael L Perlin, 'Understanding the Intersection between International Human Rights and Mental Disability Law: The Role of Dignity' in Bruce Arrigo and Heather Bersot (eds), The Routledge Handbook of International Crime and Justice Studies (Routledge 2013) 191.

43 Michael L Perlin, 'A Law of Healing' (2000) 68 U Cin L Rev 407, 420-21.

44 The relationship between stereotypes and discrimination has been studied most closely in the context of sex discrimination law. Case law has held that gender stereotypes may be actionable under anti-sex discrimination laws. See eg Nev Dep't of Human Res v Hibbs, 538 US 721, 736 (2003); Weinberger $v$ Wiesenfeld, 420 US 636, 653 (1975); see generally, Stephanie Bornstein, 'The Law of Gender Stereotyping and the Work-Family Conflicts of Men' (2012) 63 Hastings LJ 1297.

$45 \quad$ See 42 U.S.C. $\$ \$ 12101 \mathrm{ff}$.

46 Almost none of the early scholarship about the ADA even mentioned persons with mental disabilities. See Michael L Perlin, 'The ADA and Persons with Mental Disabilities: Can Sanist Attitudes Be Undone?' (1003-94) 8 J L \& Health 15, 19 (n 21) (listing articles).

$47 \quad$ Michael L Perlin, 'What's Good Is Bad, What's Bad Is Good, You'll Find out When You Reach the Top, You're on the Bottom: Are the Americans with Disabilities Act (and Olmstead v LC.) Anything More than Idiot Wind?' (2001-02) 35 U Mich J L Ref 235, 247. 
extent of discrimination faced by persons with mental disabilities. ${ }^{48}$ Of the scant attention paid to persons with mental illness in the ADA legislative debate, most focused on an ultimately unsuccessful attempt led by Senator Helms to jettison most persons with mental disabilities from the Act's protections. ${ }^{49}$ While this attempt was ultimately unsuccessful, the tenor of the debate reflects the basest sort of sanism, and serves as a paradigm for my ultimate concern about the Act's prophylactic value, and its ability to eradicate the stigmatic stereotype of sanism.

Again, Senator Helms' remarks were especially revealing. In his colloquy with Senator Harkin about hiring practices, he asked, '[h]ow is an employer ... supposed to find out whether a man is a pedophile or a schizophrenic? ${ }^{50} \mathrm{He}$ also asked whether an 'employer's own moral standards' enabled him to make hiring judgments about transvestites, kleptomaniacs, or manic depressives. Interestingly and revealingly, he made it clear that his attack was not meant to cover persons with physical disabilities: 'If this were a bill involving people in a wheelchair or those who had been injured in the war, that is one thing. ${ }^{51}$ This separating out persons with physical disabilities - especially those whose disability was battle-caused - from persons with mental disabilities cannot be ignored for the purposes of this analysis. ${ }^{52}$ To a great extent, this reflects social attitudes that link mental illness inextricably to evil, ${ }^{53}$ and even to the supernatural world. ${ }^{54}$ These conflations have profound implications for both the criminal justice and the mental disability law systems, and are, in large part, responsible for our need to blame individuals with mental disabilities for their mental disabilities, as part of our 'culture of punishment'. . $^{5}$

Senator Helms' malignant twinning of paedophiles with schizophrenics, or the notion that one might have a moral reason to violate one's civil and human

\footnotetext{
$48 \quad$ Ibid.

49 See 112 Cong Rec S10, 765-97 (daily ed 7 September 1989). The implications of this attempt are discussed in Robert L Burgdorf, Jr, 'The Americans With Disabilities Act: Analysis and Implications of a Second-Generation Civil Rights Statute' (1991) 26 Harv CR-CL L Rev 413.

$50 \quad$ See 112 Cong Rec S10, 766. There is no question that the sort of bigotry displayed here by Helms flows from his use of invidious stereotypes. For a parallel example in the area of bigotry towards gay persons via the use of stereotypes, see Franciasco Valdes, 'Queers, Sissies, Dykes, and Tomboys: Deconstructing the Conflation of "Sex," "Gender," and "Sexual Orientation" in Euro-American Law and Society” (1995) 83 Cal L Rev 1, 191-92 (1995).

51 Perlin (n 46) 28, citing and quoting 112 Cong Rec S10, 765-766; S10, 768. See also ibid S10, 783 (statements of Sen Humphrey): '[W]e are not simply talking about the blind, the deaf, or persons confined to wheelchairs.'

52 On our ambivalence about the treatment of veterans with mental illness, see Michael L Perlin, “'John Brown Went Off to War": Considering Veterans' Courts as Problem-Solving Courts' (2013) 37 Nova L Rev 445.

53 See eg Judith S Neaman, Suggestion of the Devil: The Origins of Madness (Anchor Press/ Doubleday 1975) 31, 144.

54 See eg Christopher Harding and Richard W Ireland, Punishment: Rhetoric, Rule, and Practice (Routledge 1989) 153-155.

55 See Michael L Perlin, 'The Borderline Which Separated You From Me: The Insanity Defense, the Authoritarian Spirit, the Fear of Faking, and the Culture of Punishment' (1997) 82 Iowa L Rev 1375.
} 
rights is, for want of a better word, revolting. There is no reason to doubt that these statements reflect the positions of many of his constituents.

The debate on the CRPD was more nuanced. But there are issues to consider nonetheless. In the floor debate, states repeatedly tried to return to a mere nondiscrimination model, simply repeating rights already recognised in existing treaties and hence losing the distinctive quality of the disability-specific text. ${ }^{56}$ Subsequently, in analysing a debate over a provision on women and girls with disabilities and gender, a commentator has argued that the conflation of women and children in this context reflected 'a stereotypical nod to patriarchal patterns. ${ }^{57}$

A careful consideration of legislative debates should be part of any serious scholarly agenda that seeks to get at the roots of the way we stigmatise, and why we stigmatise persons with mental disabilities.

\section{3. 'HEARTS AND MINDS'}

One question underlies these considerations: how can disability rights activists and advocates capture 'the hearts and minds' of the public 'so as to best insure that statutorily and judicially articulated rights are incorporated - freely and willingly - into the day-to-day fabric and psyche of society. ${ }^{58}$ The phrase - first used in Chief Justice Warren's opinion in Brown $v$ Board of Education of Topeka ${ }^{59}$ - was at the heart of the strategy employed by Dr Martin Luther King 'to change [the] hearts and minds of white Americans. ${ }^{60}$

This phrase needs to be read alongside of a famous quotation of Dr King's: 'The law may not be able to make a man love me, but at least it can keep him from lynching me.61 And there is valid and reliable credible evidence that, after

56 Tara Melish, 'An Eye Toward Effective Enforcement: A Technical-Comparative Approach to the Negotiations' in Maya Sabatello and Marianne Schulze (eds), Human Rights and Disability Advocacy (University of Pennsylvania Press 2014) 70, 92.

57 Mi Yeon Kim, 'Women with Disabilities: The Convention Through the Prism of Gender' in Maya Sabatello and Marianne Schulze (eds), Human Rights and Disability Advocacy (University of Pennsylvania Press 2014) 113, 121.

58 Perlin (n 46) 22. See, inter alia, in the context of the insanity defence, Perlin (n 55) 1381; of the death penalty, Michael L Perlin, 'Life Is In Mirrors, Death Disappears: Giving Life to Atkins' (2003) 33 N Mex L Rev 315, 339-340; of the relationship between lawyers and their clients with mental disabilities, Michael L Perlin, 'You Have Discussed Lepers and Crooks: Sanism in Clinical Teaching' (2003) 9 Clin L Rev 683, 719 (2003), and of the civil rights movement in general, Michael L Perlin, 'Tangled Up In Law: The Jurisprudence of Bob Dylan' (2011) 38 Ford Urb LJ 1395, 1404.

59347 US 483, 494 (1954); see also, eg Jones v Alfred H. Mayer Co., 392 US 409, 445 (1968); In re Demos, 500 US 16 (1991) (Marshall, J, dissenting from denial of certiorari).

60 Donald T Phillips, Martin Luther King, Jr. on Leadership: Inspiration \& Wisdom for Challenging Times (Prince Frederick Recorded Books 1999) 52-67, as cited in Andrew E Taslitz, 'Foreword: The Political Geography of Race Data in the Criminal Justice System' (2003) 66 Law \& Contemp Probs 1, 14 n 46.

61 Martin Luther King, Jr, 'Sermon to St. Paul's Church Cleveland Heights, Ohio' (14 May 1963) <www.stpauls-church.org/archives/sermons/king05141963.html>, as quoted in Lee J Strang, 
the enactment of civil rights legislation, when society became more meaningfully integrated, racial hate crime incidents diminished. ${ }^{62}$ Similarly, there is convincing evidence that increased contact with persons with mental illness is associated with lower stigma. ${ }^{63}$ We know that, by way of example, ' $[\mathrm{m}]$ embers of the general public are more likely to diminish prejudicial attitudes and discriminating behaviours when they have contact with people with mental illness. ${ }^{64}$

But this is all just theory until we are able to figure out how to combat the power of heuristic thinking and false 'ordinary common sense' in this enterprise. Heuristics refers to 'cognitive-simplifying device[s] through which a 'single vivid, memorable case overwhelms mountains of abstract, colorless data upon which rational choices should be made'; ${ }^{65}$ 'ordinary common sense' to a 'self-referential and non-reflective' way of thinking that 'presupposes two self-evident truths: 1) everyone knows how to assess an individual's behavior, and 2) everyone knows when to blame someone for doing wrong. ${ }^{366}$ Sanism is perpetuated and sustained by heuristic thinking and reliance on 'ordinary common sense. ${ }^{97}$ We must break this cycle of non-reflective thinking to make any serious progress in this area.

As of the writing of this article, the United States has still not ratified the UN Convention on the Rights of Persons with Disabilities. ${ }^{68}$ Perhaps ratification of this Convention will be a modest step towards this goal.

'The Clash of Rival and Incompatible Philosophical Traditions within Constitutional Interpretation: Originalism Grounded in the Central Western Philosophical Tradition' (2005) 28 Harv JL \& Pub Pol'y 909, 920 n 28.

62 See eg Donald P Green et al, 'Defended Neighborhoods, Integration, and Racially Motivated Crime' (1998) 104 Am J Sociology 372.

63 See eg Monika E Kolodziej and Blair T Johnson, 'Interpersonal Contact and Acceptance of Persons with Psychiatric Disorders: A Research Synthesis' (1996) 64 J Consulting \& Clinical Psychol 1387; David L Penn and Shannon M Couture, 'Strategies for Reducing Stigma toward Persons with Mental Illness' (2002) 1 World Psychiatry 20; Patrick W Corrigan and David L Penn, 'Lessons from Social Psychology on Discrediting Psychiatric Stigma' (1999) 54 Am Psychologist 765.

64 Patrick W Corrigan and Alicia K Matthews, 'Stigma and Disclosure: Implications for Coming Out of the Closet' (2003) 12 J Mental Health 235, 235.

65 Perlin (n 55) 1417.

66 Michael L Perlin, 'And I See Through Your Brain: Access to Experts, Competency to Consent, and the Impact of Antipsychotic Medications in Neuroimaging Cases in the Criminal Trial Process' (2009) Stanford Technol LJ 1, 24 n 84.

67 See Michael L Perlin, 'They Keep It All Hid: The Ghettoization of Mental Disability Law and Its Implications for Legal Education' (2010) 54 St Louis U L J 857, 873-74.

68 See Michelle Diament, 'Obama Urges Senate to Ratify Disability Treaty', Disability Scoop (18 May 2012) <http://www.disabilityscoop.com/2012/05/18/Obama-Urges-Senate-Treaty/ $15654 />$. The Senate failed to ratify the CRPD on 4 December 2012, for lack of a supermajority of votes. See US Intl Council on Disabilities <http://usicd.org/index.cfm> accessed 16 September 2013. The Democratic leadership has promised to bring the Convention up again for ratification in 2015. See Michael L Perlin, “"Yonder Stands Your Orphan with His Gun”: The International Human Rights Implications of Juvenile Punishment Schemes' (2013) 46 Texas Tech L Rev 301, 305 n 19. 


\subsection{VALUE OF TEST CASES}

A handful of American court decisions have come to grips with the impact that sanism can have on how society treats persons with mental disabilities. It is critical that litigators appearing before regional human rights courts and commissions emulate what the litigators in these cases have done, and force judiciaries around the world to confront the impact of stigma and stereotyping on persons with mental disabilities.

The First Circuit, by way of example, has noted that 'the belief that the mentally ill are disproportionately dangerous is precisely the type of discriminatory myth that the Rehabilitation Act and ADA were intended to confront. ${ }^{39}$ The New Mexico Supreme Court has acknowledged that '[e]ven within the disability community, persons with mental illness are often the poor stepchild, and remain the last hidden minority.' ${ }^{70}$

Perhaps the most profoundly significant of these is the decision of the Supreme Court of Montana in In re K.G.F.," ${ }^{71}$ 'without doubt, the most comprehensive decision on the scope and meaning of the right to counsel in this context from any jurisdiction in the world. ${ }^{72}$ K.G.F. was a voluntary patient at a community hospital in Montana whose expressed desire to leave the facility prompted a State petition alleging her need for commitment. Counsel was appointed, and a commitment hearing was scheduled for the next day. The State's expert recommended commitment; patient's counsel presented the testimony of the plaintiff herself and a mental health professional who recommended that the patient be kept in the hospital a few days so that a community-based treatment plan could be arranged nearer to her home. The court ordered commitment. K.G.F.'s appeal was premised, in part, on allegations of ineffective assistance of counsel. ${ }^{73}$

In a thoughtful and scholarly opinion, the Montana Supreme Court relied on state statutory and constitutional sources to find that 'the right to counsel ... provides an individual subject to an involuntary commitment proceeding the right to effective assistance of counsel. In turn, this right affords the individual with the right to raise the allegation of ineffective assistance of counsel in

\footnotetext{
69 Quiles-Quiles v Henderson, 439 F.3d 1, 6 ( $1^{\text {st }}$ Cir. 2006), quoting Perlin (n 46) 27.

70 Breen v Carlsbad Mun Schools, 120 P.3d 413, 421 (NM 2005), quoting Perlin (n 46) 20. See also, In re Eden F., 741 A.2d 873, 900 (Conn 1999), quoting Perlin (n 46) 26: 'Surveys show that mental disabilities are the most negatively perceived of all disabilities'.

7129 P.3d 485 (Mont 2001).

72 Michael L Perlin, 'I Might Need a Good Lawyer, Could Be Your Funeral, My Trial: A Global Perspective on the Right to Counsel in Civil Commitment Cases, and Its Implications for Clinical Legal Education' (2008) 28 Wash U J L \& Socl Poly 241, 245. See generally, Michael L Perlin, "There Must Be Some Way Out of Here": Why the Convention on the Rights of Persons with Disabilities Is Potentially the Best Weapon in the Fight Against Sanism' (2013) 20 Psychiatry, PsychoL \& L 462.

73 K.G.F., 29 P. 3d 488.
} 
challenging a commitment order. ${ }^{37}$ The court concluded that 'reasonable professional assistance ${ }^{35}$ - the standard for assessing effective of counsel in criminal cases in the United States - 'cannot be presumed in a proceeding that routinely accepts - and even requires - an unreasonably low standard of legal assistance and generally disdains zealous, adversarial confrontation. ${ }^{376}$

In assessing the contours of effective assistance of counsel, the court emphasised that it was not limiting its inquiry to courtroom performance; even more important was counsel's 'failure to fully investigate and comprehend a patient's circumstances prior to an involuntary civil commitment hearing or trial, which may, in turn, lead to critical decision-making between counsel and client as to how best to proceed.' Such pre-hearing matters, the court continued, 'clearly involve effective preparation prior to a hearing or trial.' The court further emphasised the role of state laws guaranteeing the patient's 'dignity and personal integrity' and 'privacy and dignity' in its decision: “"[q]uality counsel provides the most likely way - perhaps the only likely way" to ensure the due process protection of dignity and privacy interests in cases such as the one at bar.' ${ }^{77}$

After similarly elaborating on counsel's role in the client interview and the need to ensure that the patient understands the scope of the right to remain silent, the court concluded by underscoring counsel's responsibilities 'as an advocate and adversary' ${ }^{78}$ The lawyer must 'represent the perspective of the [patient] and ... serve as a vigorous advocate for the [patient's] wishes', engaging in 'all aspects of advocacy and vigorously argu[ing] to the best of his or her ability for the ends desired by the client', and operating on the 'presumption that a client wishes to not be involuntarily committed'. Thus, 'evidence that counsel independently advocated or otherwise acquiesced to an involuntary commitment - in the absence of any evidence of a voluntary and knowing consent by the patient-respondent will establish the presumption that counsel was ineffective. ${ }^{79}$ In conclusion, the court stated:

[I]t is not only counsel for the patient-respondent, but also courts, that are charged with the duty of safeguarding the due process rights of individuals involved at every stage of the proceedings, and must therefore rigorously adhere to the standards expressed herein, as well as those mandated under [state statute]. ${ }^{80}$

\footnotetext{
$74 \quad$ Ibid 491.

75 Strickland $v$ Washington, 466 US 668, 689 (1984) (establishing weak effectiveness of counsel standard). See generally 4 Michael L Perlin, Mental Disability Law: Civil and Criminal ( $2^{\text {nd }}$ edn, LexisNexis 2002), \$2B-11.2, 261-267, critiquing Strickland.

76 K.G.F., 29 P.3d at 492 (citing Michael L Perlin, 'Fatal Assumption: A Critical Evaluation of the Role of Counsel in Mental Disability Cases' (1992) 16 Law \& Hum Behav 39, 53-54 ('identifying the Strickland standard as "sterile and perfunctory" where "reasonably effective assistance" is objectively measured by the "prevailing professional norms"').

77 K.G.F., 29 P. 3d 492-494, quoting Mont Code Ann \$ 53-21-101(1), Mont Code Ann $\$ 53-21$ 142(1)), and Perlin (n 76) 47; see generally, Perlin, Funeral (n 72).

78 K.G.F., 29 P. 3d 500.

79 Ibid.

$80 \quad$ Ibid 501.
} 
And there are more cases that reflect similar values. 'Certainly, not all judges write in a sanist voice': ${ }^{31}$

Some decisions express true empathy and understanding about the plight of the institutionalised mentally disabled. A handful of judges have spent their careers rooting out sanist myths and stereotypes, and raising the legal system's consciousness about sanism's impact on all of society. Other judges, in less known cases, have also shown real sensitivity to the underlying issues. These examples, however, clearly constitute the minority of cases. Sanism regularly and relentlessly infects the courts in the same ways that it infects public discourse. ${ }^{82}$

There are some cases brought in other parts of the world with similar focuses. ${ }^{83}$ I shall elaborate on a case within a supranational human rights protection system. Victor Rosario Congo v Ecuador, a case examined by the Inter-American Commission on Human Rights, involved a 48-year-old Ecuadorian who, as a result of the State's gross negligence and wilful acts, died of malnutrition, hydroelectrolytic imbalance, and heart and lung failure. Specifically, a guard beat Mr Congo with a club on the scalp, deprived him of medical treatment, kept him naked, and forced him to endure complete isolation. ${ }^{84}$

The Inter-American Commission ${ }^{85}$ found that the State was responsible for its agents' conduct that violated Mr Congo's right to humane treatment under Article 5 of the American Convention on Human Rights (American Convention). ${ }^{86}$ The Inter-American Commission determined that Article 5 of the American Convention must be interpreted in light of the Principles for the Protection of Persons with Mental Illness and for the Improvement of Mental Health Care (MI Principles). ${ }^{87}$ This is particularly important because it made

81 See Michael L Perlin, 'Pretexts and Mental Disability Law: The Case of Competency' (1993) 47 U Miami L Rev 625, 682-83, and see cases discussed ibid 682-683.

82 Ibid 683-684. See also, Michael L Perlin, “Abandoned Love”: The Impact of Wyatt v Stickney On The Intersection Between International Human Rights And Domestic Mental Disability Law' (2011) 35 L \& Psychol Rev 121 (discussing Judge Frank Johnson's decisions in Wyatt v Stickney, 344 F Supp 373 (MD Ala 1972), affd in part, revd in part, 344 F Supp 387 (MD Ala 1972), affd in part, revd in part sub nom Wyatt $v$ Aderholt, 503 F2d 1305 (5 $5^{\text {th }}$ Cir 1974) (omnibus right to treatment case).

83 See Michael L Perlin and Meredith R Shriver, "You That Hide Behind Walls": The Relationship between the Convention on the Rights of Persons with Disabilities and the Convention Against Torture and the Treatment of Institutionalized Forensic Patients' in American University Center on Humanitarian Law (ed), Torture and Ill-Treatment in Health-Care Settings: A Compilation (2013) 195.

84 Victor Rosario Congo v Ecuador, Case 11.427, IACmHR, Rep No 63/99, OEA/Ser.L/V/II.95, doc 7 Rev $\$ 9$ (1999) (Matter of Congo).

85 On the differences between the Court and the Commission, see Terrence Rogers, 'Using International Human Rights Law to Combat Racial Discrimination in the US Criminal Justice System' (2011)14 Scholar 375.

86 <www.oas.org/juridico/english/treaties/b-32.html> accessed 8 November 2013.

87 Matter of Congo (n 74) para 54. The Principles for the Protection of Persons with Mental Illness and for the Improvement of Mental Health Care, widely referred to as the 'MI Principles.' 
the MI Principles hard law, or in other words, binding upon the UN member states that have signed it, ${ }^{88}$ nearly a decade before the CRPD was ratified. Thus, it guaranteed more extensive rights for persons with mental disabilities.

The Inter-American Commission found that the solitary confinement of $\mathrm{Mr}$ Congo constituted inhuman and degrading treatment in violation of Article 5(2) of the American Convention, especially in light of the fact he was left in isolation unable to satisfy his basic needs. ${ }^{89}$ Thus, the State violated Mr Congo's right to 'be treated with respect for the inherent dignity of the human person'. ${ }^{90}$ Further, the Inter-American Commission found that there is a duty upon the State to ensure the physical, mental and moral integrity of persons suffering from mental illness. ${ }^{91}$

The Inter-American Commission also found that the State violated Article 4(1) of the American Convention because the State failed to take measures in its power to ensure the right to life of a person who 'partly because of his state of health and in part owing to injuries inflicted on him by a State agent, was defenseless, isolated and under its control'. ${ }^{92}$ Under Article 25(1) of the American Convention, Mr Congo had a right to judicial protection, a right which the State violated because there were no judicial avenues available to establish the responsibility for his sustained injuries and death..$^{93}$ As a result of this case, the Inter-American Commission recommended that the persons responsible for the violations be punished, the family of Mr Congo be compensated, medical and psychiatric care be provided for persons suffering from mental illness, and individuals confined

GA Res 119, UN GAOR, $46^{\text {th }}$ Sess, Supp No 49, Annex 189, UN Doc A/46/49 (1991). The MI Principles are the predecessor to the CRPD. Their publication 'inspired lawyers, advocates, professors and progressive mental health professionals to begin thinking seriously about the intersection between international human rights law and mental disability law.' See Perlin, 'The Fight Against Sanism' (n 72) 463. But see Tina Minkowitz, 'The United Nations Convention on the Rights of Persons with Disabilities and the Right to be Free from Nonconsensual Psychiatric Interventions' (2007) 34 Syracuse J Intl L \& Com 405, 407 (criticising MI Principles for not being sufficiently protective of the rights of persons with psychosocial disabilities, especially in the context of the right to refuse treatment); TW Harding, 'Human Rights Law in the Field of Mental Health: A Critical Review' (2000) 101 Acta Psychiatrica Scandinavica 24, 24 (discussing how the MI Principles are 'basically flawed' and specifically referring to the right to refuse treatment). The MI Principles retain significance today in those nations that have neither signed nor ratified the CRPD. See Perlin (n 4) 9-10 (n 13). On how the discrediting of the MI Principles made them 'virtually invisible throughout the disability convention process,' see Janet E. Lord, 'Mirror, Mirror on the Wall: Voice Accountability and NGOs in Human Rights Standard Setting' (2004) 5 Seton Hall J Dipl \& Intl ReL 93, 101.

88 On how soft law becomes hard law via court decisions, see Gerald L Neuman, 'Import, Export, and Regional Consent in the Inter-American Court of Human Rights' (2008) 19 Eur J Intl L 101, 111; see generally, Gregory C. Shaffer and Mark A. Pollack, 'Hard Versus Soft Law in International Security' (2011) 52 BC L Rev 1147, 1165.

$89 \quad$ Matter of Congo (n 74) 59.

$90 \quad$ Ibid.

$91 \quad$ Ibid 62.

$92 \quad$ Ibid 69.

93 Ibid 86. See Organization of American States, American Convention on Human Rights (22 November 1969), 1144 UNTS 123 art 25(1). 
to the penitentiary system be assigned specialists to identify any psychiatric disorders. $^{94}$

There have been cases as well from the African Commission on Human Rights ${ }^{95}$ and the European Court on Human Rights, ${ }^{96}$ as well as from domestic courts in other nations. But, by and large, litigators around the world have not been vigorous in seeking to attack patterns and practices of sanism. For stigma and stereotypes to abate, this must be done.

\subsection{RELATIONSHIP TO OTHER SORTS OF STIGMA AND STEREOTYPES}

Sanism has never been taken as seriously as racism, sexism or homophobia, other than by (1) persons with disabilities, (2) (in some cases) their families, and (3) their advocates. However, a close reading of major US Supreme Court cases involving persons who have been the targets of sanist attitudes offers much to consider.

In her opinion for the Court in Olmstead v L.C., ${ }^{97}$ holding that ' $[\mathrm{u}]$ njustified isolation ... is properly regarded as discrimination based on disability', ${ }^{98}$ and ordering that states be required to maintain 'a comprehensive, effectively working plan for placing qualified persons with mental disabilities in less restrictive settings'99 - thus explicitly endorsing the ADA's 'integration mandate'100 - Justice Ruth Ginsburg made these important points:

94 Ibid 98. On how Congo '[broke] new ground' in this area of the law, see Perlin (n 4) 12.

95 See eg Michael L Perlin, 'Promoting Social Change in Asia and the Pacific: The Need for a Disability Rights Tribunal to Give Life to the UN Convention on the Rights of Persons with Disabilities' (2012) 44 Geo Wash Intl L Rev 1, 7-8, discussing how, in Purohit \& Moore $v$ The Gambia, Afr Commn on Hum and Peoples' Rts, Comm No 241/2001, P 85 (2003), the African Commission found unlawful both the way that persons with mental disabilities were treated in Gambia as well as prevailing sections of the Lunatic Detention Act of Gambia. Of note, the Commission found that Gambian domestic law violated the African Charter on Human Rights by classifying persons with mental disabilities as 'lunatics' and 'idiots.' ibid P 43. But see Mashood A Baderin, 'Recent Developments in the African Regional Human Rights System' (2005) 5 Hum Rts L Rev 117, 122 (alleging that State Parties did not implement the African Commission's recommendations), discussed in this context in Perlin (n 95).

96 See eg Michael L Perlin, "Striking for the Guardians and Protectors of the Mind": The Convention on the Rights of Persons with Disabilities and the Future of Guardianship Law' (2013) 117 Penn St L Rev 1159, 1169-1120, discussing how, in Stanev $v$ Bulgaria, App No 36760/06, ECtHR (2012) <http://bit.ly/Typ5zW> accessed 8 November 2013, the European Court of Human Rights found that Bulgaria violated Articles 3, 5, 6, and 13 of the European Convention on Human Rights in denying an individual with schizophrenia under guardianship the right to both challenge his confinement to a decrepit and unclean social care home and seek restoration of his legal capacity. For other European cases, see Michael L Perlin et al, International Human Rights Law and Comparative Mental Disability Law: Cases and Materials (Carolina Academic Press 2006) 455-782.

527 US 581 (1999).

Ibid 597.

Ibid 605-06.

28 C.F.R. pt 35 app A (1998). 
First, institutional placement of persons who can handle and benefit from community settings perpetuates unwarranted assumptions that persons so isolated are incapable or unworthy of participating in community life, $c f$. Allen v. Wright ('There can be no doubt that [stigmatising injury often caused by racial discrimination] is one of the most serious consequences of discriminatory government action'), and Los Angeles Dept. of Water and Power v. Manhart, ('In forbidding employers to discriminate against individuals because of their sex, Congress intended to strike at the entire spectrum of disparate treatment of men and women resulting from sex stereotypes'). Second, confinement in an institution severely diminishes the everyday life activities of individuals, including family relations, social contacts, work options, economic independence, educational advancement, and cultural enrichment. Dissimilar treatment correspondingly exists in this key respect: in order to receive needed medical services, persons with mental disabilities must, because of those disabilities, relinquish participation in community life they could enjoy given reasonable accommodations, while persons without mental disabilities can receive the medical services they need without similar sacrifice. ${ }^{101}$

This portion of the opinion - in some ways the most critical part of Olmstead makes two novel, interlocking points never made before by the Supreme Court. First, the Court acknowledged that the effect of discrimination against persons with mental disability is like the effect of discrimination against other persons traditionally marginalised - blacks and women (as signified by the Court in the cases it cited (Allen and Manhart) supporting the Olmstead language). ${ }^{102}$ Second, the decision recognises that the pernicious impact of discrimination cannot separate institutional isolation from other discriminatory behaviour, integrating the issue of isolation with issues of 'family relations, social contacts, work options, economic independence, educational advancement, and cultural enrichment.' ${ }^{103}$ This suggests that the Olmstead Court 'got' one of the most important structures of the ADA: that questions of institutionalisation and deinstitutionalisation are far broader than simply inquiries into whether a patient is 'behind the wall' (not for a moment to minimise the seriousness of that inquiry), and that these questions touch on virtually every important aspect of interpersonal interaction. ${ }^{104}$ There is no question that these insights cut at the core assumptions of sanism.

More than a decade before Olmstead, in his separate opinion in City of Cleburne v Cleburne Living Ctr., ${ }^{105}$ striking down as unconstitutional a Texas municipal ordinance banning group homes for persons with mental disabilities,

\footnotetext{
101 Olmstead, 527 US at 600-601 (citations omitted). On the significance of this portion of the Olmstead opinion, see Michael L Perlin, 'Their Promises of Paradise: Will Olmstead v LC Resuscitate The Constitutional Least Restrictive Alternative Principle in Mental Disability Law?' (2000) 37 Houston L Rev 999, 1035-37.

102 Perlin (n 47) 253.

103 Olmstead, 527 US 601.

104 Perlin (n 47) 254-255.

105473 US 432 (1985).
} 
Justice Marshall stressed that individuals with mental disabilities have been subject to ' $[\mathrm{a}]$ regime of state-mandated segregation and degradation ... that in its virulence and bigotry rivaled, and indeed paralleled, the worst excesses of Jim Crow. ${ }^{106}$ This remarkably strong opinion, again, acknowledges the pernicious power of sanism, and shows that at least one justice of the Supreme Court from nearly three decades ago understood the underlying issues.

While Justice Ginsburg's comment about how institutional segregation 'perpetuates unwarranted assumptions that persons so isolated are incapable or unworthy of participating in community life ${ }^{107}$ has been cited frequently by courts and academics, ${ }^{108}$ remarkably, Justice Marshall's observation has only been cited once subsequently in a reported decision - by Justice Marshall himself in an opinion dissenting from a denial of certiorari in a death penalty case involving a prisoner with a significant mental disability. ${ }^{109}$ It has been referred to a handful of times in the academic literature, ${ }^{110}$ but it certainly has not been incorporated into the 'scholarly unconscious' of those who write about this topic. Litigators and scholars must embrace these persuasive and vivid arguments and use them regularly in their representation of and advocacy on behalf of this population.

\subsection{IMPACT OF THE CRPD ${ }^{111}$}

The United Nations Convention on the Rights of Persons with Disabilities (CRPD) $)^{112}$ is 'regarded as having finally empowered the "world's largest minority" to claim their rights, and to participate in international and national affairs on an equal basis with others who have achieved specific treaty recognition and

$106 \quad$ Ibid 462.

107 Olmstead, 527 US at 600.

108 See eg Lane v Kitzhaber, 841 F Supp 2d 1199, 1205 (D Or 2012); Haddad v Dudek, 784 FSupp2d 1308, 1321-1322 (MDFla. 2011); Benjamin v Department of Public Welfare of Penn 768 FSupp2d 747, 752 (MD Pa 2011); Samuel Bagenstos, 'The Past and Future of Deinstitutionalization Litigation' (2012) 34 Cardozo L Rev 1, 32; Kevin M Cremin, 'Challenges to Institutionalization: The Definition of 'Institution' and the Future of Olmstead Litigation' (2012) 17 L143, 155; Leslie Salzman, 'Guardianship for Persons With Mental Illness - A Legal and Appropriate Alternative?' (2012) 4 St Louis U J Health L \& Poly 279, 283 n 19.

109 See Smith $v$ Francis, 474 US 925, 927 n 1 (1985) (Marshall, J, dissenting from denial of certiorari). See also ibid 927: 'I believe, however, that the courts bear a special responsibility when faced with the possible execution of a member of a group that has been subject for so long to irrational social stigma.'

110 See eg Leslie Salzman, 'Rethinking Guardianship (Again): Substituted Decision Making as a Violation of the Integration Mandate of Title II of the Americans with Disabilities Act' (2010) 81 U Colo L Rev 157, 164 n 19; Michael E Waterstone and Michael Ashley Stein, 'Disabling Prejudice' (2008) 102 Nw U L Rev 1351, 1359 n 59; Edward Haas, 'Associate Justice Thurgood Marshall: An Indispensable Voice in the Struggle for the Civil Rights of People with Disabilities' (2002) 12 Seton Hall Const LJ 371, 431.

111 This section is generally adapted from Perlin and Schriver (n 83).

112 Convention on the Rights of Persons with Disabilities, GA Res 61/106, UN Doc A/RES/61/106 (24 January 2007) (CRPD); see generally Perlin (n 4) 143-59. 
protection.' ${ }^{113}$ This Convention is the most revolutionary international human rights document ever created that applies to persons with disabilities. ${ }^{114}$ It furthers the human rights approach to disability and recognises the right of people with disabilities to equality in most every aspect of life. ${ }^{115}$ It firmly endorses a social model of disability and reconceptualises mental health rights as disability rights - a clear and direct repudiation of the medical model that traditionally was partand-parcel of mental disability law. ${ }^{116}$ "The Convention sketches the full range of human rights that apply to all human beings, all with a particular application to the lives of persons with disabilities. ${ }^{\prime 117}$ It provides a framework for insuring that mental health laws 'fully recognize the rights of those with mental illness'. ${ }^{118}$ There is no question that it has 'ushered in a new era of disability rights policy'. ${ }^{119}$

It describes disability as a condition arising from 'interaction with various barriers [that] may hinder their full and effective participation in society on an equal basis with others' instead of inherent limitations, ${ }^{120}$ and extends existing human rights to take into account the specific rights experiences of persons with disabilities. ${ }^{121}$ It calls for 'respect for inherent dignity'122 and 'non-discrimination'. ${ }^{23}$ Subsequent articles declare freedom from 'arbitrary or unlawful interference' with privacy, ${ }^{124}$ 'freedom from torture or cruel, inhuman or degrading treatment or punishment'. ${ }^{125}$ 'freedom from exploitation, violence and abuse', ${ }^{126}$ and a right to protection of the 'integrity of the person'. ${ }^{127}$

\footnotetext{
113 Rosemary Kayess and Phillip French, 'Out of darkness into light? Introducing the convention on the rights of persons with disabilities' (2008) 8 HRLRev 1, $4 \mathrm{n} 17$.

114 See generally, Michael L Perlin and Eva Szeli, 'Mental Health Law and Human Rights: Evolution and Contemporary Challenges' in Michael Dudley et al (eds), Mental Health and Human Rights: Vision, Praxis, and Courage (OUP 2012) 98; Perlin (n 4) 3-21; Perlin (n 5).

115 See eg Aaron Dhir, 'Human Rights Treaty Drafting Through the Lens of Mental Disability: The Proposed International Convention on Protection and Promotion of the Rights and Dignity of Persons with Disabilities' (2005) 41 Stan J Intl L 181.

116 Phillip Fennel, 'Human Rights, Bioethics, and Mental Disorder' (2008) 27 Med \& L 95. See generally, Perlin (n 95).

117 Janet E Lord and Michael A Stein, 'Social Rights and the Relational Value of the Rights to Participate in Sport, Recreation, and Play' (2009) 27 BU Intl L J 249, 256; see also, Ronald McCallum, 'The United Nations Convention on the Rights of Persons with Disabilities: Some Reflections'<http://ssrn.com/abstract=1563883> accessed 8 November 2013.

118 Bernadette McSherry, 'International Trends in Mental Health Laws: Introduction' (2008) 26 Law In Context 1,8 .

119 Paul Harpur, 'Time to Be Heard: How Advocates Can Use the Convention on the Rights of Persons with Disabilities to Drive Change' (2011) 45 Val U L Rev 1271, 1295.

120 CRPD (n 102) Art 1 and PmbL para E.

121 Frédéric Mégret, 'The Disabilities Convention: Human Rights of Persons with Disabilities or Disability Rights?' (2008) 30 HRQ 514-515; see Perlin (n 4) 143-158.

122 CRPD (n 102) Art 3(A).

123 Ibid Art 3(B).

124 Ibid Art 14(1).

125 Ibid Art 15.

126 Ibid Art 16

127 Ibid Art 17.
} 
The CRPD is unique because it is the first legally binding instrument devoted to the comprehensive protection of the rights of persons with disabilities. ${ }^{128}$ It not only clarifies that states should not discriminate against persons with disabilities, but also sets out explicitly the many steps that states must take to create an enabling environment so that persons with disabilities can enjoy authentic equality in society. ${ }^{129}$

These Articles provide us with the clearest anti-sanism blueprint ever drafted. If taken seriously, the CRPD can potentially be the best weapon - ever - in the fight against sanist stereotypes that stigmatise persons with mental disabilities.

\section{THERAPEUTIC JURISPRUDENCE ${ }^{130}$}

One of the most important legal theoretical developments of the past two decades has been the creation and dynamic growth of therapeutic jurisprudence. ${ }^{131}$ Initially employed in cases involving individuals with mental disabilities, but subsequently expanded far beyond that narrow area, therapeutic jurisprudence presents a new model for assessing the impact of case law and legislation, recognising that, as a therapeutic agent, the law that can have therapeutic or anti-therapeutic consequences. ${ }^{132}$ The ultimate aim of therapeutic jurisprudence is to determine whether legal rules, procedures, and lawyer roles can or should

128 See generally, Perlin (n 95).

129 On the changes that ratifying states need to make in their domestic involuntary civil commitment laws to comply with Convention mandates, see Bryan Y Lee, 'The UN Convention on the Rights of Persons with Disabilities and Its Impact upon Involuntary Civil Commitment of Individuals with Developmental Disabilities' (2011) 44 Colum J L \& Socl Probs 393. See also, István Hoffman and György Könczei, 'Legal Regulations Relating to the Passive and Active Legal Capacity of Persons with Intellectual and Psychosocial Disabilities in Light of the Convention on the Rights of Persons with Disabilities and the Impending Reform of the Hungarian Civil Code' (2010) 33 Loy LA Intl \& Comp. L Rev 143 (on the application of the CRPD to capacity issues); Kathryn D DeMarco, 'Disabled by Solitude: The Convention on the Rights of Persons with Disabilities and Its Impact on The Use of Supermax Solitary Confinement' (2012) 66 U Miami L Rev 523 (on the application of the CRPD to solitary confinement in correctional institutions).

130 This section is largely adapted from Perlin and Schriver (n 83), and from Michael L Perlin and Alison J Lynch, “"Toiling in the Danger and in the Morals of Despair”: Risk, Security, Danger, the Constitution, and the Clinician's Dilemma' (2015) <http://papers.ssrn.com/sol3/papers. cfm?abstract_id=2363494>.

131 See eg David B Wexler, Therapeutic Jurisprudence: The Law as a Therapeutic Agent (Carolina Academic Press 1990); David B Wexler and Bruce J Winick, Law in a Therapeutic Key: Recent Developments in Therapeutic Jurisprudence (Carolina Academic Press 1996); Bruce J Winick, Civil Commitment: A Therapeutic Jurisprudence Model (Carolina Academic Press 2005); David B Wexler, 'Two Decades of Therapeutic Jurisprudence' (2008) 24 Touro L Rev 17. Wexler first used the term in a paper he presented to the National Institute of Mental Health in 1987. See David B Wexler, 'Putting Mental Health into Mental Health Law: Therapeutic Jurisprudence' (1992) 16 L \& Hum Behav 27, 27, 32-33.

132 See Michael L Perlin, "His Brain Has Been Mismanaged with Great Skill”: How Will Jurors Respond to Neuroimaging Testimony in Insanity Defense Cases?' (2009) 42 Akron L Rev 885, 912; see Kate Diesfeld and Ian Freckelton, 'Mental Health Law and Therapeutic Jurisprudence' 
be reshaped to enhance their therapeutic potential while not subordinating due process principles. ${ }^{133}$ There is an inherent tension in this inquiry, but David Wexler clearly identifies how it must be resolved: 'the law's use of 'mental health information to improve therapeutic functioning [cannot] impinge upon justice concerns. ${ }^{\text {'134 }}$ Put another way, '[a]n inquiry into therapeutic outcomes does not mean that therapeutic concerns "trump" civil rights and civil liberties.'135

Therapeutic jurisprudence 'asks us to look at law as it actually impacts people's lives' ${ }^{136}$ and focuses on the law's influence on emotional life and psychological well-being. ${ }^{137}$ It suggests that 'law should value psychological health, should strive to avoid imposing anti-therapeutic consequences whenever possible, and when consistent with other values served by law should attempt to bring about healing and wellness'. ${ }^{138}$ Therapeutic jurisprudence understands that, 'when attorneys fail to acknowledge their clients' negative emotional reactions to the judicial process, the clients are inclined to regard the lawyer as indifferent and a part of a criminal system bent on punishment.' ${ }^{139}$ By way of example, therapeutic jurisprudence 'aims to offer social science evidence that limits the use of the incompetency label by narrowly defining its use and minimizing its psychological and social disadvantage.' ${ }^{\text {'40 }}$

in Ian Freckelton and Kate Peterson (eds), Disputes and Dilemmas in Health Law 91 (Federation Press 2006) (for a transnational perspective).

133 Perlin, 'Lepers' (n 58); Michael L Perlin, 'And My Best Friend, My Doctor/Won’t Even Say What It Is I've Got: The Role and Significance of Counsel in Right to Refuse Treatment Cases' (2005) 42 San Diego L Rev 735. On how TJ 'might be a redemptive tool in efforts to combat sanism, as a means of 'strip[ping] bare the law's sanist façade', see Michael L Perlin, "Baby, Look Inside Your Mirror"': The Legal Profession's Willful and Sanist Blindness to Lawyers with Mental Disabilities' (2008) 69 U Pitt L Rev 589, 591. See also Bernard P Perlmutter, 'George's Story: Voice and Transformation through the Teaching and Practice of Therapeutic Jurisprudence in a Law School Child Advocacy Clinic' (2005) 17 St Thomas L Rev 561, 599 n 111 (same); Ian Freckelton, 'Therapeutic Jurisprudence Misunderstood and Misrepresented: The Price and Risks of Influence’ (2008) 30 T Jefferson L Rev 575, 585-586 (same).

134 David B Wexler, 'Therapeutic Jurisprudence and Changing Concepts of Legal Scholarship' (1993) 11 Behav Sci \& L 17, 21. See also eg David Wexler, 'Applying the Law Therapeutically' (1996) 5 Appl \& Prevent Psychol 179.

135 Perlin (n 35) 412; Michael L Perlin, 'Where the Winds Hit Heavy on the Borderline: Mental Disability Law, Theory and Practice, Us and Them' (1998) 31 Loy LA L Rev 775, 782.

136 Bruce J Winick, 'Foreword: Therapeutic Jurisprudence Perspectives on Dealing With Victims of Crime' (2009) 33 Nova L Rev 535, 535.

137 David B Wexler, 'Practicing Therapeutic Jurisprudence: Psychological Soft Spots and Strategies, in Daniel P Stolle, David B Wexler and Bruce J Winick (eds), Practicing Therapeutic Jurisprudence: Law as a Helping Profession (Carolina Academic Press 2000) 45.

138 Bruce Winick, 'A Therapeutic Jurisprudence Model for Civil Commitment' in Kate Diesfeld and Ian Freckelton (eds), Involuntary Detention and Therapeutic Jurisprudence: International Perspective on Civil Commitment (Ashgate 2003) 23, 26.

139 Evelyn H Cruz, 'Competent Voices: Noncitizen Defendants and the Right to Know the Immigration Consequences of Plea Agreements' (2010) 13 Harv Latino L Rev 47, 59.

140 Claire B Steinberger, 'Persistence and Change in the Life of the Law: Can Therapeutic Jurisprudence Make A Difference?' (2003) 27 Law \& Psychol Rev 55, 65. The most thoughtful sympathetic critique of TJ remains Christopher Slobogin, 'Therapeutic Jurisprudence: Five Dilemmas to Ponder' (1995) 1 Psychol Pub Poly \& L 193. 
In its aim to use the law to empower individuals, enhance rights, and promote well-being, therapeutic jurisprudence has been described as 'a sea-change in ethical thinking about the role of law'. ${ }^{141}$ That is, therapeutic jurisprudence supports an ethic of care. ${ }^{142}$

One of the central principles of therapeutic jurisprudence is a commitment to dignity. ${ }^{143}$ Professor Amy Ronner describes the 'three Vs': voice, validation and voluntariness, ${ }^{144}$ arguing:

What 'the three Vs' commend is pretty basic: litigants must have a sense of voice or a chance to tell their story to a decision maker. If that litigant feels that the tribunal has genuinely listened to, heard, and taken seriously the litigant's story, the litigant feels a sense of validation. When litigants emerge from a legal proceeding with a sense of voice and validation, they are more at peace with the outcome. Voice and validation create a sense of voluntary participation, one in which the litigant experiences the proceeding as less coercive. Specifically, the feeling on the part of litigants that they voluntarily partook in the very process that engendered the end result or the very judicial pronunciation that affects their own lives can initiate healing and bring about improved behaviour in the future. In general, human beings prosper when they feel that they are making, or at least participating in, their own decisions. ${ }^{145}$

The question to be addressed here is this: given the pervasiveness of stigma and sanism, is it remotely possible that Prof. Ronner's vision - of voice, voluntariness and validation - will be fulfilled? ${ }^{146}$ Therapeutic jurisprudence - by forcing us to focus on the therapeutic and anti-therapeutic outcomes of court decisions, statutes, rules and roles - illuminates the way that pretextuality and sanism drive the mental disability law system. ${ }^{147}$ Just as, in domestic law in the United States, the application of the ADA to key areas of patients' civil rights law can 'combat

${ }_{141}$ Warren Brookbanks, 'Therapeutic Jurisprudence: Conceiving an Ethical Framework' (2001) 8 JL \& Med 328, 329-330.

${ }_{142}$ See eg Bruce J Winick and David B Wexler, 'The Use of Therapeutic Jurisprudence in Law School Clinical Education: Transforming the Criminal Law Clinic' (2006) 13 Clinical L Rev 605, 605-07. The use of the phrase dates to Carol Gilligan, In a Different Voice (Harvard University Press 1982).

${ }_{143}$ See Bruce J Winick, Civil Commitment: A Therapeutic Jurisprudence Model (Carolina Academic Press 2005) 161.

144 Amy D Ronner, 'The Learned-Helpless Lawyer: Clinical Legal Education and Therapeutic Jurisprudence as Antidotes to Bartleby Syndrome' (2008) 24 Touro L Rev 601, 627. On the importance of 'voice,' see also Freckelton (n 133) 588.

145 Amy D Ronner, 'Songs of Validation, Voice, and Voluntary Participation: Therapeutic Jurisprudence, Miranda and Juveniles' (2002) 71 U Cin L Rev 89, 94-95; See generally, Amy D Ronner, Law, Literature and Therapeutic Jurisprudence (Carolina Academic Press 2010).

146 On the relationship between therapeutic jurisprudence and the scope of international human rights law, see Michael L Perlin, “'The Ladder of the Law Has No Top and No Bottom': How Therapeutic Jurisprudence Can Give Life to International Human Rights' (2014) 37 Intl J L \& Psychiatry 535.

147 Michael L Perlin, 'Therapeutic Jurisprudence: Understanding the Sanist and Pretextual Bases of Mental Disability Law' (1994) 20 N Eng J Crim \& Civ Confinement 369, 374. 
sanism, ... and provide a building block of therapeutic jurisprudence,'148 so can - and should - the CRPD have the same impact on international human rights law. ${ }^{149}$

\section{CONCLUSION}

These seven points are, of course, not exhaustive. But they provide a basic blueprint for efforts to combat the pernicious stereotypes that diminish the quality of life of persons with mental disabilities, both in institutions and in the community. A careful consideration of therapeutic jurisprudence values will make it more likely that important progress be made in this area so that Professor Ronner's values of 'voice, validation and voluntariness' can be fulfilled.

Return to the title of this chapter and its focus on 'humanity'. Not Dark Yet is a fairly pessimistic song, but as noted earlier, not one without hope. And Dylan has shown us, in the eighteen-plus years since Time out of Mind (the album on which Not Dark Yet was released), that be still searches for, and finds, 'the light'. ${ }^{150}$ This should be an inspiration to all of us.

\footnotetext{
148 Michael L Perlin, “Make Promises by the Hour": Sex, Drugs, the ADA, and Psychiatric Hospitalization' (1997) 46 De Paul L Rev 947, 956-57. Importantly, the ADA was amended in 2008 precisely to 'legislatively overrule' specific US Supreme Court decisions - see eg Sutton v United Air Lines, 527 US 471 (1999); Toyota Motor Mfg. $v$ Williams, 534 US 184 (2002) - that had limited the definition of and significance of 'disability' under the ADA, see ADA Amendments Act of 2008, (2008) Pub L No 110-325, and making it clear that, in the employment sector, the ADA was designed to protect: people with disabilities who can do the job with reasonable accommodations, but who don't get hired because of unfounded stereotypes,' Elizabeth Pendo, 'Substantially Limited Justice?: The Possibilities and Limits of a New Rawlsian Analysis of Disability-Based Discrimination’ (2003) 77 St. John's L Rev 225, 263, quoting Professor Scott C Burris. See generally, Michael L Perlin and Heather Ellis Cucolo, Mental Disability Law: Civil and Criminal (LexisNexis 2013 Cum Sup) sections 5A-2.4, at 100-101.

149 See eg Perlin (n 4) 203-228. See also Perlin (n 95) 36 n 221.

150 See Atwood (n 8).
} 



\title{
RACIAL STEREOTYPES AND HUMAN RIGHTS
}

\author{
Mathias MösCHEL*
}

This contribution maps the difficulties of recognising racial stereotypes as a human rights issue. Starting from the most serious human rights violations occurring in in conjunction with some form of physical violence, moving on to human rights violations in the absence of such violence, and finishing with the analysis of the practice of two specialised international human rights institutions fight against racism (CERD and ECRI), the argument is that so far insufficient explicit attention is paid to racial stereotyping in binding international law. A comparison with the different recognition of gender stereotypes under human rights law strengthens this argument and shows, at the same time, how fighting against racial stereotypes could and should become a broader human rights law issue.

This contribution argues that racial stereotypes and/or stereotyping are insufficiently taken into account under binding human rights law and international criminal law. The role played by such stereotypes in contributing to ongoing structural racial discrimination is either ignored or only implicitly/ indirectly addressed, and only very rarely explicitly recognised as a human rights violation. Instead, in non-binding recommendations their role is better highlighted but the limited impact of such recommendations - as welcome as they may be - warrants that more needs to be done.

Before entering into the substance of this article, it is important to explain some key terms and distinctions, mainly that between (racial) prejudices and (racial) stereotypes. So far, lawyers have not been heavily involved in untangling the differences between these terms and it is certainly not my aim to do so here. But the distinctions that have been elaborated mainly in the literature of social

Mathias Möschel is Associate Professor at the Central European University (Budapest). He can be reached at moschelm@ceu.edu. Earlier drafts of this contribution have been presented at the conferences 'Stereotyping as a Human Rights Issue' at Ghent University in December 2013 and 'Global Challenges and New Perspectives on Equality Law' at Université Libre de Bruxelles in May 2014. The author has profited from the discussions and comments during these conferences and wishes to thank Alexandra Timmer and the anonymous reviewers for their comments on the drafts. Any errors and omissions are the author's alone. 
psychology, show why speaking in terms of stereotypes is conceptually and also qualitatively somewhat different. While there is no unitary definition of stereotypes and/or prejudice, some social psychologists have defined the former as 'beliefs about another group in such terms as personality traits, attributions, or behavioural descriptions' and the latter as 'negative attitudes toward another group that express negative affective or emotional reactions.' ${ }^{1}$ Others have added that prejudices serve to 'create and maintain hierarchical status relations between groups' and that stereotypes 'shape how people think about and respond to the group'. 2

According to these definitions, stereotypes are broader than prejudices. First, they can include both negative and positive (emotional) reactions. For instance, the fact that certain racial minorities are more industrious than others, that certain racial minorities are rich, or that certain groups of people (such as Filipinos) are more caring than others towards children or the elderly would not be necessarily considered a racial prejudice. But these certainly can be interpreted as racial stereotypes. Second, they are not limited to intentional negative attitudes but often extend also to unconscious understandings and orderings of our world. Third, there is a clearer normative dimension linked to stereotypes in the sense that they not only extend to certain characteristics but also to the roles that are or should be performed by certain groups, ie women should behave in a certain way; immigrants do not integrate/should integrate; Roma people are lazy and criminal and should rely less on social welfare, etc. Indeed, once the lens of (racial) stereotypes is applied, one can understand how these conscious or unconscious beliefs about groups can also imprison them in certain roles, destine them automatically towards certain professions and even serve as an argument for genocide, as was the case for Jews. For these reasons, speaking and researching in terms of stereotypes rather than of racial prejudice has the advantage of allowing a broader framework of analysis and critique of both domestic and international law. ${ }^{3}$ It allows going beyond the limited framework of intentional, negative behaviours that underpin racial prejudice towards the (often) unintentional beliefs, assignment of certain roles and hierarchical orderings that structure our societies along different lines, amongst which also racial and ethnic ones.

\footnotetext{
1 Daniel Bar-Tal, 'Delegitimization: The Extreme Case of Stereotyping and Prejudice' in Daniel Bar-Tal et al (eds), Stereotyping and prejudice: Changing perceptions (Springer 1989) 169 (referring to other authors). See a very similar definition in Charles Stangor (ed), Stereotypes and Prejudice: Essential Readings (Taylor and Francis 2000) 1.

2 John F Dovidio et al, 'Prejudice, Stereotyping and Discrimination: Theoretical and Empirical Overview' in John F Dovidio et al (eds), The SAGE Handbook of Prejudice, Stereotyping and Discrimination (Sage 2010) 7 and 8.

3 See eg for analyses in terms of gender stereotypes in international law: Rebecca Cook and Simone Cusack, Gender Stereotyping: Transnational Legal Perspectives (University of Pennsylvania Press 2010) and Alexandra Timmer, 'Toward an Anti-Stereotyping Approach for the European Court of Human Rights' (2011) 11 HRLR 707.
} 
This contribution will be subdivided into four sections. Section 1 will analyse racial stereotypes when they arise in conjunction with the exercise of violence and how limited attention is given to the role they play in the perpetration of violent acts against racial minorities. Section 2 will look at how racial stereotypes fare when they emerge in the absence of violence or the threat thereof and how in this area as well there is limited acknowledgement in binding case law of racial stereotyping as being problematic. Section 3 then looks at the practice of two human rights institutions, the United Nations' Committee on the Elimination of All Forms of Racial Discrimination (CERD Committee) and the European Commission against Racism and Intolerance (ECRI). To conclude, section 4 will compare and contrast the combat against racial stereotypes with the fight against gender stereotypes which has recently made great steps forward in human rights law and literature. This comparison helps identifying the differences between gender and racial stereotypes in the domain of human rights law and also shows how such law may come into play in the future when fighting racial stereotypes.

\section{RACIAL STEREOTYPES AND VIOLENCE}

The first area to analyse is not necessarily linked to classical human rights categorisations (civil/political and socio-economic/cultural rights) but rather to the presence or absence of some form of violence. This is in part justified by the intuition that possibly in these gravest forms of human rights violations, the underlying racial stereotypes which allowed such violence to explode and to be exercised would be taken into account. Needless to say, there are different levels of violence ranging from the gravest form in terms of (a) genocide and state-sponsored extermination policies based on racial prejudice, to (b) racially motivated state actions that happen without necessarily requiring an official state policy, and finally to (c) private race-based violence. Starting from the most brutal and focused form of violence, namely genocide, to the less invasive but possibly more widespread and detailed exercise of violence through private individuals, we will see that in all these forms of violence racial prejudice and/or stereotyping underpin the behaviour of different actors but that racial stereotypes have only become limitedly explicitly relevant as a violation of human rights and international criminal law.

\subsection{IN RELATION TO STATE-ORGANISED VIOLENCE/GENOCIDE}

Genocide researchers agree that racial prejudices and stereotypes constitute one of the founding stones permitting extermination measures to be taken against 
certain groups of people. ${ }^{4}$ Thus, the long existing stereotypes and prejudices against Jewish, Roma and/or Tutsi people, for example, revived and made broadly accessible through propaganda, prepared the terrain for their genocide to happen. ${ }^{5}$

What may be somewhat surprising is that there is seemingly no international case law on genocide explicitly linking racial stereotypes with the actual crime of genocide. One explanation could be that it is implicit that genocide takes place when racial stereotypes are acted upon and that by consequence they are automatically subsumed in the higher crime of genocide and therefore become invisible. Where the link instead becomes visible is in the distinction between incitement to commit genocide and 'mere' hate speech.

In fact, the Genocide Convention bans speech that constitutes direct incitement to commit genocide. ${ }^{6}$ A proposed Article III which would have also punished 'all forms of public propaganda tending by their systematic and hateful character to provoke genocide, or tending to make it appear as a necessary, legitimate or excusable act' was not adopted. ${ }^{7}$ Interestingly the explanatory comments state that ' $\mathrm{s}$ ] uch propaganda is even more dangerous than direct incitement to commit genocide' and that '[g]enocide cannot take place unless a certain state of mind has previously been created'. ${ }^{8}$ However, the proposed article was eventually not retained. ${ }^{9}$ In a similar vein, more than fifty years later the Rome Statute of the International Criminal Court specifies that individual criminal responsibility with regard to genocide applies only when someone directly and publicly incites others to commit genocide. ${ }^{10}$ It is exactly this distinction between 'mere' hate speech and propaganda and/or hate speech that incites to commit genocide which became relevant in a couple of cases involving genocide and incitement to genocide in Yugoslavia and Rwanda.

In the Kordic Trial Judgment of the International Criminal Tribunal for the Former Yugoslavia (ICTY), an indictment against Dario Kordic for hate speech as a crime against humanity was rejected by the judges because hate speech in itself does not constitute a crime against humanity, because it is not enumerated

$4 \quad$ Fine describes this as 'religious traditions of contempt and collective defamation, stereotypes, and derogatory metaphor indicating the victim is inferior, sub-human ... or super-human $\ldots$ and that if certain groups are "pre-defined as alien ... subhuman or dehumanized or the enemy" they must "be eliminated on order that we may live". Helen Fine, Genocide: A Sociological Perspective (Sage 1993) 26 (emphasis added).

5 See eg Tonja Salomon, 'Freedom of Speech v Hate Speech: The Jurisdiction of "Direct and Public Incitement to Commit Genocide"' in Ralph Henman and Paul Behrens (eds), The Criminal Law of Genocide (Ashgate 2007), 141.

$6 \quad$ Article 3(c) of the Convention on the Prevention and Punishment of the Crime of Genocide.

7 Secretariat Draft, Draft Convention on the Crime of Genocide, UN Doc E/447, 26 June 1947, published in Hirad Abtahi and Philippa Webb, The Genocide Convention. The Travaux Préparatoires (Martinus Nijhoff Publishers 2008) vol 1, 239-241.

$8 \quad$ Ibid 239.

9 For more details on the Genocide Convention's drafting history, see: William A Schabas, 'Hate speech in Rwanda: The Road to Genocide' (2000) 46 McGill LJ 141.

10 Article 25(3)(e) of the Rome Statute of the International Criminal Court. 
as a crime elsewhere in the ICTY's Statute, and because hate speech has not attained the status of customary international law. ${ }^{11}$ The Appeals Chamber of the International Criminal Tribunal for Rwanda (ICTR), instead, reached a different conclusion in what became known as the Media case. ${ }^{12}$ The issue was whether some individuals in charge of certain radio stations and newspapers which had received government funding and support in Rwanda that had produced and diffused hate-filled messages based on stereotyped images of the Tutsi, were guilty of direct and public incitement to genocide as opposed to simple hate speech. On appeal, the international judges confirmed the Trial Judgment's conviction for this crime, while reversing some other charges. ${ }^{13}$ Precisely the distinction between incitement to genocide and hate speech gave rise to a partly dissenting opinion by judge Meron who found the Appeals Chamber had gone too far in extending the application of international criminal law to mere hate speech. ${ }^{14}$ However, the important point to highlight here is that the propaganda brimming with negative stereotypes broadcast over radio coupled with the ensuing genocide of the Tutsi, were linked in this case and considered as sufficiently grave to convict even those who were not physically involved in the killings but who provided the ideological backdrop for the genocide. ${ }^{15}$

However, beyond these limited examples relating to hate speech and genocide, there is little evidence that the case law on genocide or state-organised violence goes into depths of analysis in terms of racial stereotypes.

\subsection{RACIALLY MOTIVATED/BIASED VIOLENCE BY STATE OR PUBLIC ACTORS}

This second category differs from the first one, in as much as the racial stereotypes do not give rise to an official, coordinated state policy, or toleration thereof, attaining the level of genocide but are nevertheless at the basis of some other form of violent state action. The way in which racial stereotypes come into play here is that they can be interpreted as indicia or as a prima facie case showing that the violence was racially motivated and therefore contrary to human rights standards and non-discrimination provisions. In fact, racial stereotypes and prejudices often

11 ICTY, Prosecutor v Kordić \& Cerkez, Case No IT-95-14/2-T, Judgment, 26 February 2001, para 209.

12 ICTR, Ferdinand Nahimana, Jean-Bosco Barayagwiza, Hassan Ngezwe v Prosecutor, Case No ICTR-99-52-A, Judgment, 28 November 2007.

13 Ibid paras 673-892.

$14 \quad$ Judge Meron, partly dissenting opinion, 375-381.

15 For more details on this decision as well as earlier decisions by the ICTR on direct incitement to commit genocide, see Tonja Salomon and Harmen van der Wilt, 'Between Hate Speech and Mass Murder: How to Recognize Incitement to Genocide’ in Harmen van der Wilt et al (eds), The Genocide Convention. The Legacy of 60 Years (Martinus Nijhoff Publishers 2012) 41-50. 
underpin racially discriminatory behaviour and are therefore reliable indicia for a certain state of mind/conscience.

Especially the case law by the European Court of Human Rights (ECtHR or Court) on anti-Romani police violence demonstrates to what extent such actions are often based on racist bias and stereotypes without the Court recognising or acknowledging them as problematic. I have analysed and critiqued this line of cases more in detail elsewhere, especially with regard to the difficulty of the ECtHR to recognise Article 14 (prohibition of discrimination) violations. ${ }^{16}$ For the purposes of this contribution, it is interesting to analyse what counts as racially stereotyped expressions and what contexts lead the European judges to believe there was indeed discriminatory, racist violence at play to either trigger a procedural Article 14 violation because no investigation had been made into the potential racist motives behind the violence or a substantive Article 14 violation, meaning that the violence itself was triggered by racist stereotypes.

Before entering into the case description and analysis, it should be mentioned what the types of stereotypes and prejudice about Roma people consist of. Stereotypes and/or prejudices about Roma people include for instance that they are seen as having innate propensities to commit crimes, as being beggars and thieves, as being disproportionately reliant on welfare, as being uneducated, as not wanting to work or to integrate into society, as being nomadic and as being musicians/artists. ${ }^{17}$ Often these stereotypes and prejudices get concentrated in and expressed by the derogatory word 'gypsy' which, when used by media, elected officials, or police forces, demonstrates the understanding that Roma people are less worthy, less human, thereby encouraging and justifying violent actions against them.

For this reason, the case law in which the reference made to 'gypsies' is particularly indicative of the (pre-)existence of such stereotypes or prejudices. Nevertheless, the way the ECtHR uses such indicia is quite incoherent. In some cases the reference made to 'gypsies' by the aggressor police forces or by the official investigators looking into the affair, or in official statements has been found as not being indicative of racially motivated attacks or racially biased ineffective investigations, thus allowing the ECtHR to fully dismiss the non-discrimination claim. ${ }^{18}$ In other cases, such references or remarks were found at least to have triggered a procedural Article 14 violation, meaning that the State should at

16 Mathias Möschel, 'Is the European Court of Human Rights' case law on anti-Roma violence "beyond reasonable doubt?"' (2012) 12 HRLR 479.

17 For more details, see the report by Thomas Hammarberg, Commissioner for Human Rights of the Council of Europe entitled 'Human Rights of Roma and Travellers in Europe', 2012, especially 39-61 <www.coe.int/t/commissioner/source/prems/prems79611_GBR_Couv HumanRightsOfRoma_WEB.pdf $>$.

18 See eg Anguelova v Bulgaria (2002) 38 EHRR 659; Balogh v Hungary App no 47940/99 (ECtHR, 20 July 2004); Osman v Bulgaria 47 EHRR 1067; Vasil Sashov Petrov v Bulgaria App no 63106/00 (ECtHR, 10 June 2010); and Soare and Others $v$ Romania App no 24329/02 (ECtHR, 22 February 2011). 
least have investigated into the potential racial motives behind the violence. This was the case in Nachova $v$ Bulgaria, one of the key anti-Romani violence cases, which involved two Romani army conscripts who were shot by a Bulgarian military officer who was overheard by a witness as saying, 'You damn Gypsies' while standing over the bodies of the dead. ${ }^{19}$ Similarly, the tendentious remarks made by a deputy police director in regard to the applicant's Roma origin during an administrative investigation was held to be sufficient at least to trigger the obligation of investigating potential racial motives in the applicant's illtreatment. ${ }^{20}$ Or again, in a case involving the beating of a Romani man by the police the reference to the victim as 'Gypsy' by the investigators and as 'antisocial elements prone to violence and theft' by the military prosecutor in charge of the case at the national level, induced the ECtHR to find a procedural violation of Article 14 in conjunction with Article 3 (prohibition of torture, or inhuman or degrading treatment or punishment). ${ }^{21}$

However, there is so far only one case in which such racially stereotyped remarks were found to lead to a substantive Article 14 violation and which like many of the cases described above involved the ill-treatment of a Romani individual by the police. ${ }^{22}$ Interestingly, this is also one of the few cases where the ECtHR refers explicitly to stereotypes when it ruled that the remarks in the police report that the villagers' behaviour was 'purely Gypsy' and that, at the request of the deputy mayor so as to teach the Roma a lesson, the police officers asked the victim whether he was 'Gypsy or Romanian' before beating him up. ${ }^{23}$ In this case, the Court did find a link between the violence and the racial/racist context in which it took place and thus found a full Article 14 violation in conjunction with Article 3.

However, there is no clear line of reasoning to be drawn from the case law in terms of when the Court finds that certain stereotypes which are acted upon by the states' authorities are relevant or not. In most cases mentioned above, the ECtHR did find Article 2 (right to life) or Article 3 violations. But the key point, namely that these violations most probably occurred precisely because of underlying racial stereotypes and prejudice against Roma individuals, was rejected or not explicitly acknowledged in most instances.

\footnotetext{
Nachova and Others v Bulgaria (2005) 42 EHRR 933.

Petropoulou-Tsakiris v Greece 48 EHRR 1109.

Cobzaru v Romania 47 EHRR 10.

Stoica $v$ Romania 52 EHRR 918.

Ibid paras 7 and 122 .
} 


\subsection{RACIALLY MOTIVATED/BIASED VIOLENCE BY PRIVATE ACTORS}

Similar observations and/or conclusions could be made in a line of cases which is only marginally different from that observed immediately here above. The difference mainly resides in the legal relevance for human rights purposes (not in terms of the persecution and daily discrimination suffered by the Romani victims of such violence!) of whether the violence was exercised by the State or by private individuals. Here the existing stereotypes against racial minorities (and in the ECtHR's case law it is mostly against Roma) as criminal, as parasitic, and by consequence as subhuman are acted upon by private individuals who attack, kill and destroy Roma individuals and settlements. In such human rights cases, the State 'only' intervenes at the investigation or trial level. As a consequence, its liability in terms of human rights violation can only be procedural, meaning that the investigation or judgment into the facts were racially biased or prejudiced.

Once this point has been clarified, we find the same difficulties which the ECtHR already demonstrated when fully-fledged state action and violence was at stake. Thus, in yet another case involving Bulgaria, the ECtHR held that the utterance of 'you damn gypsies' during a fatal attack on the eventual victim was not sufficient to have triggered an obligation by the State to investigate into the racial prejudice leading to the death. ${ }^{24}$ In another case, the Court did heed the racist slogans yelled during an attack and physical assault on Romani houses and individuals, but only to declare an Article 3 procedural violation instead of also engaging a separate analysis for a (procedural) Article 14 violation. ${ }^{25}$ So again, this case law demonstrates the ECtHR's limited understanding of how stereotypes lead to racial discrimination and how the failure of state authorities to investigate such background may in itself be based on stereotypes.

This first part of my contribution has demonstrated the mitigated success in human rights law and humanitarian law of recognising racial stereotypes if not as a self-standing human rights violation in terms of genocide or race discrimination then at least as an accessory violation. There is some limited recognition that such stereotypes when leading to violence constitute a human rights problem. However, this is rather the exception than the rule.

The next section will explore whether the recognition of racial stereotypes by human rights law fares better when they emerge in the absence of violence.

$24 \quad$ Dimitrova and Others $v$ Bulgaria App no 44862/04 (ECtHR, 27 January 2011).

$25 \quad$ Koky and Others $v$ Slovakia App no 13624/03 (ECtHR, 12 June 2012). 


\section{RACIAL STEREOTYPES IN THE ABSENCE OF VIOLENCE}

If racial stereotypes were already limitedly recognised as constituting a problem for human rights purposes when arising in conjunction with violence, it should come as little surprise that the picture is as mitigated when no such violence is exercised. Here, three different domains in which racial stereotypes have come into play in international human rights law so far will be looked at: (a) the right to a fair trial, (b) racial profiling, and (c) racist speech not leading to violence.

\subsection{RACIAL BIAS IN COURT DECISIONS}

One of the few areas of human rights law in which one can certainly identify sensitivity to racial prejudices and/or stereotypes is when they emerge during trial and give rise to issues of a fair and unbiased judgment. For example, the ECtHR has dealt with a fact pattern involving physical and structural violence and discrimination against Roma, including a combination of arson against Romani houses and property, lynching by angry mobs with active police participation and the eventual impunity of the perpetrators. In the first Moldovan and Others judgment, Romania entered into a friendly settlement agreement, admitting that the events posed problems under various articles of the European Convention on Human Rights (ECHR), including Article 3 and Article $14 .{ }^{26}$ However, not all the plaintiffs accepted the friendly settlement and this led to a second judgment. ${ }^{27}$ In terms of stereotypes, the second Moldovan judgment is interesting because they arose during the criminal trial decision following the events. In fact, the Romanian judges described the Roma community as follows:

Due to their lifestyle and their rejection of the moral values accepted by the rest of the population, the Roma community has marginalised itself, shown aggressive behaviour and deliberately denied and violated the legal norms acknowledged by society. Most of the Roma have no occupation and earn their living by doing odd jobs, stealing and engaging in all kinds of illicit activities. As the old form of common property that gave them equal rights with the other members of the community was terminated, the Roma population were allocated plots of land. However, they did not work the land and continued to steal, to commit acts of violence and to carry out attacks, mainly against private property, which has generated even more rejection than before. ${ }^{28}$

\footnotetext{
$26 \quad$ Moldovan and Others $v$ Romania (No 1) App nos 41138/98 and 64320/01 (ECtHR, fr. settl., 5 July 2005).

$27 \quad$ Moldovan and Others $v$ Romania (No 2) App nos 41138/98 and 64320/01 (ECtHR, 12 July 2005).

$28 \quad$ Ibid para 44.
} 
Whereas the ECtHR considered the racial elements of the attacks as an aggravating factor under Article 3 and not as a separate Article 14 violation, it held that the judge's remarks as well as others made during related proceedings had determined unfavourable outcomes for the victims and thus constituted, inter alia, a violation of Article 14 in conjunction with Article 6 (right to a fair trial).

In another case before the ECtHR, ${ }^{29}$ a Romani woman was denied probation in a fraud case against her because according to the national judges granting parole would have created a sense of impunity, especially for members belonging to ethnic minorities. This also led the ECtHR to find an Article 14 violation in conjunction with Article 6. In other words, when racial stereotypes determine the outcome of judicial decisions and distort the exercise of unbiased justice, this causes a human rights violation in terms of absence of a fair trial even in the absence of any violence.

\subsection{RACIAL PROFILING}

Racial profiling is another area in which racial stereotypes play a certain role. Racial profiling has been on the increase since the 'war on terrorism' and related security issues but also in conjunction with immigration issues. The stereotypes here are mainly that all people of colour or those wearing certain (religious) clothing are identified as either being more probably a terrorist or an irregular migrant and therefore more prone to continuous border or police checks. However, the practice certainly goes further back in time and has to do with the notion that racial minorities, immigrants and/or Roma supposedly have a propensity towards crime and violence and thus constitute a threat for society. ${ }^{30}$

The UN Human Rights Committee was the first international human rights body to condemn such practices by declaring that police identity checks which are motivated by race or ethnicity violate the international human right to nondiscrimination. ${ }^{31}$ The case was brought by Ms Williams, an American naturalised Spanish citizen, who was the only person to be stopped and asked for her identity documents at a Spanish train station by a police officer. She claimed that she was targeted because she was a Black woman but lost her case at the national level. The Human Rights Committee, on the contrary, held that the identity check had taken place only on the basis of the petitioner's racial characteristics which violates Article 26 (non-discrimination) of the International Covenant on Civil

\footnotetext{
$29 \quad$ Todorova v Bulgaria App no 37193/07 (ECtHR, 25 March 2010).

30 See more broadly on racial profiling: Frederick Schauer, Profiles, Probabilities and Stereotypes (HUP 2003) 155-198 and Karen S Glover, Racial Profiling. Research, Racism, and Resistance, (Rowman \& Littlefield Publishers 2009).

$31 \quad$ HRC, Rosalind Williams Lecraft v Spain, Communication No 1493/2006, 17 August 2009 (CCPR/C/96/D/1493/2006).
} 
and Political Rights. However, it should be noted that there is little in the Human Rights Committee's analysis explicitly linking the profiling to racial stereotyping. Nevertheless, like the proverbial swallow that does not make a summer, this important decision does not yet constitute a strong, binding human rights jurisprudence against racial profiling.

\subsection{RACIAL IMAGERY OR DEPICTIONS NOT LEADING TO VIOLENCE}

A last 'non-violent' area in which the issue of racial stereotypes has emerged in human rights law is that of racial imagery or depictions and which, while not directly inciting to violence, is offensive, degrading and/or discriminatory. The question is whether and how far such imagery violates certain human rights which would mean that some of the racial imagery that we are used to seeing would need to be prohibited by the State or that States have an obligation to restrict access to them. ${ }^{32}$ Clearly here we enter into the additional issue of the limits of freedom of speech and the different levels of protection from racist speech and imagery existing around the world.

Probably for this reason, human rights law and national courts have been somewhat reluctant to recognise this issue as a violation. The ECtHR's Grand Chamber decision Aksu $v$ Turkey $^{33}$ is a perfect example. At stake were two publications, a dictionary which was in part financed by the Turkish Ministry of Culture and a book written by an Associate Professor and published by the Turkish Ministry of Culture. Both publications represented the Roma as thieves and contained negative, discriminatory and prejudiced connotations. Mr Aksu, a Turkish Roma, complained that these publications offended him as a member of the Roma community and claimed an Article 8 violation (right to private life) in conjunction with an Article 14 violation. The ECtHR rejected the Article 14 claim because the applicant has not succeeded in producing prima facie evidence that the impugned publications had a discriminatory intent or effect. ${ }^{34}$ As far as Article 8 is concerned, the Court framed the issues as one of positive obligations of the State and whether the Turkish State adequately protected the applicant's private life from the authors/publishers of the books. Having to balance this right with the freedom of expression, the Court concluded that Turkey had offered sufficient protection thus also rejecting the Article 8 claim. Nevertheless, in terms

\footnotetext{
32 In this sense, see: Gregor Maučec, 'Does international law require the removal of racially offensive material from libraries and bookstores?' (2013) 3 SACHA JHR 1.

33 Aksu $v$ Turkey App nos 4149/04 and 41029/04 (ECtHR [GC], 15 March 2012). See the comment using a racial stereotypes analysis: Alexandra Timmer, 'Stereotypes of Roma: Aksu v Turkey in the Grand Chamber', Strasbourg Observers Blog, 20 March $2012<$ http:// strasbourgobservers.com/2012/03/20/stereotypes-of-roma-aksu-v-turkey-in-the-grandchamber/> accessed 16 April 2015.

34. Aksuv Turkey, para 45.
} 
of racial stereotyping, the judges stated that 'any negative stereotyping of a group, when it reaches a certain level, is capable of impacting on the group's sense of identity and the feelings of self-worth and self-confidence of members of the group'. ${ }^{35}$ Hence, one can sense that some sort of sensitivity to the harms created by racial stereotypes is there, but it is so far just not sufficient to amount to the level of a human rights violation. In spite of acknowledging the potential damages to Roma, the European judges, in this case held that the racial stereotypes contained in these publications are not sufficiently serious to matter for human rights/ discrimination purposes.

Another example of non-violent racial imagery that has come to the attention of international human rights fora and which demonstrates the difficulties in acknowledging that racially stereotypical images constitute any sort of harm and (human) rights violation, is the case of Zwarte Piet (Black Pete) in the Netherlands, a Black figure who accompanies and helps St Nicholas (alias Santa Claus). Allegedly, his skin colour is black because he is a chimney sweeper. In spite of this origin, he is mostly represented as a Black person in racially stereotyped ways. Zwarte Piet has obtained global attention thanks to a letter by a number of UN experts and special rapporteurs sent to the Dutch government ${ }^{36}$ denouncing this practice and asking it to stop. A racial stereotyping approach which might attempt at contextualising such imagery and how it is offensive for Black Dutch or European citizens because it harks back to colonial times would certainly strengthen the human rights claims against this tradition and practice.

For that same issue, at the national level, human rights have also been invoked to challenge this tradition when a trial court held that Article 8 (and not Article 14!) of the ECHR had been violated due to the mayor of Amsterdam giving permission for the festive arrival of St. Nicholas together with Zwarte Piet without taking into account the discriminatory effect of the latter figure. ${ }^{37}$ However, that judgment was overruled on appeal by the Dutch Council of State which held that the mayor is not allowed to refuse permission for public manifestations because of their content. The claimants should have lodged a civil or criminal case against the organisers of the St Nicholas parade instead of acting against the mayor. ${ }^{38}$

As one can see, absent some form of violence, the recognition of racial stereotypes by binding human rights law is haphazard at best, quite limited,

Ibid para 58 .

36 Communication to the Government of the Netherlands signed by Verene Shepherd (Chair Rapporteur of the Working Group on people of African descent), Farida Shaheed (Special Rapporteur in the field of cultural rights), Rita Itsák (Independent Expert on minority issues) and Mutuma Ruteere (Special Rapporteur on contemporary forms of racism, racial discrimination, xenophobia and related intolerance) (17 January 2013) (AL Af Descent 2012 Cultural rights (2009) Minorities (2005-4) G/SO 214 (78-15) NLD 1/2013) <https://spdb. ohchr.org/hrdb/23rd/public_-_AL_Netherlands_17.01.13_(1.2013).pdf>.

37 Amsterdam District Court, 3 July 2014, case no 13/6350. The author wishes to thank the anonymous reviewer for this update.

38 Administrative Jurisdiction Division of the Council of State, 12 November 2014, case no $201406757 / 1 /$ A3. 
and rarely explicit. At this point, it might be useful to look at the practices and decisions of two institutions whose main goal is to combat racism and how the issue of racial stereotypes is increasingly emerging here.

\section{SPECIALISED HUMAN RIGHTS BODIES AGAINST RACISM}

Over the years, two specialised bodies have been created to fight racism at the international human rights level. These are (a) the Committee which overviews the implementation of the United Nations' Convention on the Elimination of All Forms of Racial Discrimination and (b) the European Commission against Racism and Intolerance.

\subsection{INTERNATIONAL CONVENTION ON THE ELIMINATION OF ALL FORMS OF RACIAL DISCRIMINATION (ICERD)}

On 4 January 1969, the United Nations' International Convention on the Elimination of All Forms of Racial Discrimination (ICERD) entered into force. Under it, a committee of experts (CERD Committee) was created which supervises its application and issues general recommendations, state reports and also decides individual complaints of human rights violations. For the purposes of this contribution, two provisions come into play. On the one hand, Article 7, which deals with educational measures preventing race discrimination and on the other hand, Article 4 which deals with hate speech.

\subsubsection{Article 7}

Article 7 provides that:

States Parties undertake to adopt immediate and effective measures, particularly in the fields of teaching, education, culture and information, with a view to combating prejudices which lead to racial discrimination and to promoting understanding, tolerance and friendship among nations and racial or ethnical groups ... [emphasis added].

Even though the word 'stereotype' does not appear here, we are at an earlier stage than prejudices leading to violence. Indeed, at stake here are prejudices that lead to racial discrimination especially in the domains of education and the media. Note also that the language of this provision does not limit itself to the fields of 
teaching, education, culture and information and could therefore also be applied to other domains.

So far, Article 7 has been the object of one General Recommendation, in which the CERD Committee regretted that few States Parties include information on the measures which they have adopted and which give effect to Article 7 of the Convention in their reports, and that moreover such information has often been general and perfunctory. ${ }^{39}$

The issue of racial prejudices in the media also arose in another General Recommendation No 27 in which the CERD Committee 'encouraged awareness among professionals of all media of the particular responsibility to not disseminate prejudices and to avoid reporting incidents involving individual members of Roma communities in a way which blames such communities as a whole. ${ }^{40}$ Last but not least, stereotyping is also mentioned in its General Recommendation No 30, where the Committee recommends that measures taken against terrorism do not lead to racial profiling or stereotyping and that resolute action be taken to counter tendencies to target stigmatise, stereotype or profile non-citizens on the basis of their race, colour, descent, and national or ethnic origin. ${ }^{41}$ However, there is nothing binding in this language, and the CERD Committee has neither interpreted Article 7 broadly, nor granted this provision such a central, 'mandatory' position as the Committee supervising the application of the United Nations' Convention on the Elimination of All Forms of Discrimination Against Women (CEDAW) has done in relation to Article 5 of CEDAW of which more in detail further below.

An analysis of the CERD Committee's individual decisions provides little more information on the practice relating to Article 7. In two cases, violations of Article 7 have been invoked in conjunction with other provisions of CERD. The first one was brought by a Dutch citizen of Surinamese origins who claimed to have been discharged from the Netherlands Police Academy (NPA) on racial grounds evidenced by statements such as that he was a bad learner, that his Dutch was insufficient and that he should pattern himself on the white male police officers; being registered each time he was late for classes which was not the case for white students; and upon not performing well enough at a physical exercises, being told by the sports teacher that: ' $t$ ] he muscles needed for performing this exercise well are poorly developed in apes'. ${ }^{42}$ After having unsuccessfully litigated his way through the national system, the petitioner held that these facts amounted to a violation of Articles 2, 5, 6 and 7 of CERD. The CERD Committee recognised that there were some racial connotations of a serious nature in the matter but that the claims at the national level mainly dealt with the dismissal which it agreed

CERD Committee, General Recommendation No 5 (CERD/C/GC/5, 1977).

CERD Committee, General Recommendation No 27 (CERD/C/GC/27, 2000).

CERD Committee, General Recommendation No 30 (CERD/C/GC/30, 2004).

CERD Committee, EIF $v$ the Netherlands, Communication No 15/1999, 21 March 2001

(CERD/C/58/D/15/1999). 
seemed rather caused by the petitioner's bad results at the Academy than by racial discrimination. Thus they found no violation.

The second case took place in Australia and dealt with a sporting ground named the 'E.S. 'Nigger' Brown Stand', in honour of a well-known sports personality, Mr E.S. Brown who, in spite of being White, had seemingly acquired the nickname 'Nigger' because he liked to use 'Nigger Brown' shoe polish. ${ }^{43}$ The sign with the name on the grandstand of the sporting ground offended Mr Hagan, an aboriginal Australian. After having his claims to remove the sign dismissed at the national level, he petitioned the CERD Committee for violation of Articles 2, 4, 5, 6 and 7 of CERD. In particular, he contended that the term is among the most racially offensive words in English and that for this reason he and his family were unable to attend functions at this football venue. The Committee first noted that the offending term was not designed to demean or diminish Mr Brown who was neither Black or of aboriginal descent and that the sign had gone by without any objections for many years. Nevertheless, it added that meanings of terms can change and that the CERD is a living instrument which must be interpreted and take into account the circumstances of contemporary society. Moreover, it noted that there are other ways to honour a sportsperson than by maintaining and displaying a public sign considered to be racially offensive. Therefore it recommended that the State Party take the necessary measures to secure the removal of the offending term from the sign in question. This decision shows more sensitivity to the issue of racial imagery and words than the previous one. The mere fact that such an expression may have a negative impact on someone, regardless of discriminatory intent, and also in consideration of the changing meaning of the words was sufficient for the CERD Committee to find a violation. However, it never openly refers to racial stereotypes and the damages they may cause.

Instead, the CERD Committee refers explicitly to such stereotypes in its analysis of State reports. For example, in its recent concluding observations on the Italian state report the issue of racial stereotypes, especially with regard to the Roma, comes up at several points. ${ }^{44}$ To Austria it recommended taking 'resolute action to counter any tendency, especially from politicians, to target, stigmatize, stereotype or profile people on the basis of race, colour, descent and national or ethnic origin, or to use racist propaganda in politics' ${ }^{45}$ In the concluding observations to the state reports by Chile and Ecuador it recommends that effective educational and awareness-raising measures are taken in order to

43 CERD Committee, Hagan $v$ Australia, Communication No 26/2000, 20 March 2003 (CERD/C/62/D/26/2002).

44 CERD Committee, Concl Obs - Italy, 9 March 2012 (CERD/C/ITA/CO/16-18) paras 17, 19 and 25.

45 CERD Committee, Concl Obs - Austria, 21 August 2008 (CERD/C/AUT/CO/17) para 16. 
counter any tendency to stereotype or stigmatise migrants. ${ }^{46}$ Thus, we can observe a concern by the ICERD Committee in combating racial stereotypes in a number of domains and there is a large margin in using Article 7 more broadly, especially as far as individual decisions are concerned.

\subsubsection{Article 4}

The second provision under which the issue of stereotypes has emerged especially in the CERD Committee's individual decisions has to do with the issue of hate speech. Article 4 provides that:

States Parties condemn all propaganda and all organizations which are based on ideas or theories of superiority of one race or group of persons of one colour or ethnic origin, or which attempt to justify or promote racial hatred and discrimination in any form, and undertake to adopt immediate and positive measures designed to eradicate all incitement to, or acts of, such discrimination.

We have already seen how the issue of hate speech and publications containing stereotypical images and language has been dealt with in international criminal law and also by the ECtHR. The CERD Committee has only addressed the problem of hate speech in a recent general recommendation. ${ }^{47}$ In this document, racial stereotypes are explicitly mentioned as an issue of concern, ${ }^{48}$ to be avoided in media representations of ethnic, indigenous and other groups, ${ }^{49}$ but also that freedom of expression assists vulnerable groups in the deconstruction of racial stereotypes. ${ }^{50}$ However, it is probably in its 'case law' interpreting Article 4 where a true stereotyping perspective emerges, thus going further than the CERD Committee's Article 7 jurisprudence. Even though it does not explicitly use the word 'stereotypes' in those individual decisions, nevertheless this UN treaty body shows an understanding of how dangerous they can be, even in the absence of incitement to violence.

Thus, one recent case ${ }^{51}$ involved the publication of an interview of Thilo Sarrazin, a former politician from Berlin in which he made a number of denigrating, stereotypical statements about Turks and Arabs in Germany, their lack of integration, their welfare dependence, their unproductiveness, their lower class and higher birth-rate, their lower IQ compared to Eastern European Jews.

46 CERD Committee, Concl Obs - Ecuador, 24 October 2012 (CERD/C/ECU/CO/20-22) para 15 and CERD Committee, Concl Obs - Chile, 23 September 2013, CERD/C/CHL/CO/19-21, para 18.

47 CERD Committee, General Recommendation No 35 (CERD/C/GC/35, 2013).

$48 \quad$ Ibid para 6.

Ibid para 40.

Ibid para 29.

CERD Committee, TBB-Turkish Union in Berlin/Brandenburg v Germany, Communication No 48/2010, 4 April 2013 (CERD/C/82/D/48/2010). 
These stereotypes then served to propose a revamp of the social security system and also of restricting immigration only to highly qualified individuals. The criminal charges filed by a Turkish-German association against such statements at the domestic level failed on the grounds that those statements were part of a significant public intellectual debate. The Committee held that Mr Sarrazin's statements 'contain ideas of racial superiority, denying respect as human beings and depicting generalized negative characteristics of the Turkish population, as well as incitement to racial discrimination in order to deny them access to social welfare'.52 Balancing these statements against the issue of freedom of speech, it held that Germany had failed to effectively investigate the issue of incitement to racial hatred and recommended that Germany 'review its policies and procedures concerning the prosecution in cases of alleged racial discrimination consisting of dissemination of ideas of superiority over other ethnic groups ... and of incitement to discrimination on such grounds. ${ }^{53}$

This case illustrates how the CERD Committee understands the risks underlying publications/statements brimming with racist stereotypes and their detrimental effects even when they do not directly lead to violence. Other cases by the same body seem to confirm this trend that racist speech will be given somehow less freedom than in other international bodies. ${ }^{54}$ However, even here the case law is far from unidirectional. In fact, on the one hand, clearly the issue of free speech and the risks of restriction loom everywhere as indicated by the dissenting opinion to this individual decision by the CERD Committee. ${ }^{55}$ On the other hand, in another case involving again Germany, the same committee did not find that statements against Roma and Sinti depicting them as criminals and as social welfare parasites published by a Bavarian police officer constituted a violation of Article $4 .{ }^{56}$ Here the same legal framework as above was not deemed to be insufficient, mainly because in the concrete case it did not find the authorities (re)actions arbitrary and because the policeman had received disciplinary measures. ${ }^{57}$

Ultimately, we see that in the work of this specialised body, the issue of racial stereotypes is acknowledged to some extent as constituting a human rights violation, especially with regard to Article 4 decisions. However, mostly the provisions adopted by the CERD Committee are non-binding and somehow remain between the lines.

Ibid para 12.6 .

Ibid para 14.

See eg The Jewish Community of Oslo et al v Norway, Communication No 30/2003, 15 August 2005 (CERD/C/67/D/30/2003) in particular para 10.5 .

55 Ibid. Individual opinion by Committee member, Mr Carlos Manuel Vazquez (CERD/C/82/3).

56 CERD Committee, Zentralrat Deutscher Sinti und Roma et al $v$ Germany, Communication No 38/2006, 3 March 2008 (CERD/C/72/D/38/2006).

$57 \quad$ Ibid para 7.7. 


\subsection{EUROPEAN COMMISSION AGAINST RACISM AND INTOLERANCE (ECRI)}

Some developments going into the direction of recognising that racial stereotypes and prejudices can become relevant for human rights purposes even without violence can also be gleaned from the documents of another institution, this time at the level of the Council of Europe: the European Commission against Racism and Intolerance (ECRI).

Contrary to the CERD Committee, the ECRI cannot decide on individual cases but like the former institution it issues general policy recommendations and country reports. And indeed it invokes stereotyping explicitly in a number of its recommendations. Thus, the link between stereotypes and racial profiling is explicitly made by the ECRI in its General Policy Recommendation No 11 where it states that ' $\mathrm{r}$ ] acial profiling is mainly the result of stereotypes existing among the police, whereby certain groups of persons designated by grounds such as race, colour, language, religion, nationality or national or ethnic origin are presumed to be more prone than others to commit offences or certain kinds of offences. However, the prohibition of racial profiling must also cover those situations where the link between stereotypes and racial profiling is more difficult to establish'. ${ }^{58}$ Also, in its General Policy Recommendation No 13, it recommends that governments of members states take measures for preventing and combating stereotypes, prejudice and discrimination experienced by Roma children in schools, by making parents of non-Roma children aware of it and by training teaching staff in particular for intercultural education; ${ }^{59}$ that school textbooks do not convey stereotypes on Roma; ${ }^{60}$ to combat prejudices and stereotypes concerning Roma and Travellers in respect of access to housing; ${ }^{61}$ and to provide training to health workers aimed at combating stereotypes, prejudice and discrimination against Roma. ${ }^{62}$

Some country reports also highlight the attention which ECRI pays to racial stereotypes and the necessity to fight them at various levels. Thus, in its latest report on Spain, it deplored manifestations of the stereotype that Jews have too much power and cartoons equating Jews or Israelis with Nazis and that those prejudices contribute to the feeling of vulnerability of Jews in Spain. ${ }^{63}$ The latest Italian report in turn deplored the many stereotypes and prejudices existing against Roma people in Italy. ${ }^{64}$

ECRI, General Policy Recommendation No 11, 29 June 2007 (CRI(2007)39) para 37.

ECRI, General Policy Recommendation No 13, 24 June 2011 (CRI(2011)37) para 4b.

Ibid para 4q.

Ibid para $6 \mathrm{~g}$.

Ibid para 7d.

ECRI, Report on Spain, 7 December 2010 (CRI (2011)4) para 142.

ECRI, Report on Italy, 6 December 2011 (CRI (2012)2) para 83. 
It could be said that possibly the ECRI is the most advanced institution in openly acknowledging and addressing the issue of racial stereotypes under human rights law. It understands stereotypes as being the basis of racial profiling and more generally of playing out both in the area of civil and political and social and economic rights, in the presence or in the absence of violence. Yet it may be that ECRI is so bold because its interpretations are non-binding recommendations, which may provide arguments for binding cases or persuasive authority but, for the time being, little more.

In conclusion to this third part, we see that racial stereotypes under ICERD and ECRI certainly are acknowledged. However, this acknowledgement comes mostly in form of recommendations and non-binding decisions. This opens the discussion on some of the potential developments which a fight against racial prejudice and stereotypes may mean at the human rights level.

\section{FIGHTING RACIAL STEREOTYPES THROUGH HUMAN RIGHTS IN THE FUTURE?}

Parts of this contribution already hinted at the way in which racial stereotypes could occupy a more central place in human rights analysis.

One way of conceiving how racial stereotypes may become more relevant in the future can be gleaned when comparing them with gender stereotypes in human rights law and especially with the use made by the fundamental provision of Article 5 of CEDAW. Without entering too much into the details that are explained much better and more in detail by others, ${ }^{65}$ this provision helps understanding how the fight against racial stereotyping is more limited than what occurs in terms of gender stereotyping in human rights law. In fact, what appears from this article is that State Parties need to take all appropriate measures to modify the social and cultural patterns of conduct, prejudices and practices that are based on the inferiority or superiority of either of the sexes as well as breaking down the gendered parental roles. In General Recommendation No 25 the CEDAW Committee has elevated Article 5 from a seemingly marginal provision to a corner stone in the CEDAW's architecture by including the fight against gender stereotypes amongst the three main obligations State Parties have in their efforts to eliminate discrimination against women. ${ }^{66}$

Therefore, one of the first things that could be done is to draft a similar general recommendation by the CERD Committee which could elevate Article 7 of ICERD to similar heights as Article 5 of CEDAW. While still being 'soft international human rights law', such a general recommendation would have

\footnotetext{
65 Rikki Holtmaat, 'Article 5' in Marsha Freeman, Christine Chinkin and Beate Rudolf (eds), The UN Convention on the Elimination of All Forms of Discrimination Against Women. A Commentary (OUP 2011) 141-167.

66 CEDAW Committee, General Recommendation No 25 (2004) para 6.
} 
the advantage of explicitly addressing the role played transversally by racial stereotypes for the different rights recognised in the ICERD. It would also have the benefit of clarifying to what extent such stereotypes are problematic, how they relate to freedom of speech and which international obligations arise as a result of fighting and deconstructing such stereotypes.

It is precisely with regard to this last point of deconstructing such stereotypes that the comparison with what is happening at the level of gender stereotypes becomes relevant. Indeed what we see occurring in this domain is that what is seen as (increasingly) problematical are the social, cultural and economic roles based on ideas of inferiority or superiority attributed to women and men and that influence our societies and their ordering at the very basis of its existence. In a certain way one could say that the fight against gender stereotypes is increasingly about undoing the sexual contract which Carol Pateman identified so well ${ }^{67}$ or about eliminating some of its consequences. ${ }^{68}$

To keep the parallel and comparison with gender stereotypes in relation to the sexual contract and the ways in which fighting against such stereotypes may undo or deconstruct this contract, the situation looks quite different with regard to race. In his seminal book, political theorist Charles Mills has identified the racial contract as underlying modern Western societies. ${ }^{69} \mathrm{He}$ posits that this contract was concluded amongst those that are identified on various and varying grounds as White, to categorise the remaining humans as non-White and of a different and inferior moral status. Moral and legal rules that normally regulate behaviour amongst whites do not apply in dealings with non-Whites or only apply with certain limitations. ${ }^{70}$ Ultimately, the racial contract is a contract to exploit people of colour to the economic, cultural and political benefit of White people. This contract was able to be sustained also because of existing prejudices and stereotypes about non-Whites: uncivilised, culturally backward, childlike, lazy, incapable of self-rule. These are just some of the characterisations that have served to justifying and maintaining the racial contract not only by force and violence but also ideologically. Thus by fighting stereotypes, the social, cultural and economic roles that are de facto attributed on the basis of some prior racial ordering or which are the result of the latter and that constitute the basis of racial states ${ }^{71}$ would be at least (legally) exposed. Not only would this again touch upon some racial imagery mentioned above and become relevant in the educational

Carole Pateman, The Sexual Contract (SUP 1988).

68 Similar observations can be made with regard to the national level, when the German Bundesverfassungsgericht identifies gender stereotypes with the expression 'überkommene Rollenverteilung' (see eg: BVerfG, 24 January 1995, 1 BvL 18/93 and 5, 6, 7/94, 1 BvR 403, 569/94, para 73; and BVerfG, 9 November 2011, 1 BvR 1853/11, para 18) and the US Supreme Court with 'ancient canards about the proper role of women' (Phillips v Martin Marietta Corp., 400 US 542, 545 (1971) (Marshall, J., concurring)).

C Mills, The Racial Contract (Cornell University Press 1997).

Ibid 11.

David Theo Goldberg, The Racial State (Blackwell Publishers 2002). 
domain, but it would equally touch upon the racially ordered division of labour or other patterns of social stereotyping related to racial minorities.

For instance, in many restaurants in big cities of Western Europe the menial kitchen work is mostly done by Black or immigrant workers whereas the waiters are often White. Similar observations could be made with regard to Black or Filipino domestic workers in economically developed countries. Again, the parallel with gender stereotypes may help to highlight the different legal relevance of the two situations: if the same labour division were gendered, in the sense that women were predominantly working in the kitchen and the men waiting on tables, gender stereotypes would or at least could be invoked. However, the racial contract is much harder to break down through (human rights) law. Hence, thinking about gender stereotypes and how they play out in the human rights domain may help to frame future claims or develop solutions that take into account how racial stereotypes compound certain outcomes and that go beyond the declaration or recommendation level. ${ }^{72}$

An example of how to configure a broader human rights approach which takes into account racial stereotypes comes from the recent ECtHR judgment, Biao $v$ Denmark, involving a family reunification claim in Denmark. ${ }^{73}$ The legal issue at stake was whether it amounted to indirect discrimination to impose an attachment requirement or 28 years of life in Denmark to all Danish citizens in order to be allowed to apply for family reunion given that the impact for naturalised Danish citizens, who are often of a different race/ethnicity, would be that such reunion comes at a much later time in life. In this concrete case, the applicant of Togolese origins had applied for asylum, married and divorced a Danish woman, obtained a residence permit in Denmark, and finally obtained Danish citizenship between 1993 and 2002. In 2003, he married a Ghanaian woman and intended to have her come to Denmark but the request for family reunification was refused on the grounds of the requirements mentioned above. Had he been a Danish born citizen, this would not have been the case, thus negatively impacting persons who acquire Danish nationality later in life far more often and far more heavily than persons born with Danish nationality.

The Court held that there was no violation of the applicants' Article 8 and/or Article 14 rights. Whereas it did find that there had been an indirect difference in treatment based on status it nevertheless found that there was an objective justification for the 28-year and attachment rules, namely to demonstrate strong ties to the country, and that the rule was proportional. ${ }^{74}$ However, for the

\footnotetext{
72 See for instance an early example of awareness of the economical, educational and cultural elements of racism and race prejudice: UNESCO, Declaration on Race and Racial Prejudice, Paris, 27 November 1978.

73 Biao v Denmark App no 38590/10 (ECtHR, 25 March 2014). It should be noted that this case has been referred to the Grand Chamber, so more information on racial stereotypes might be forthcoming.

$74 \quad$ Ibid paras 79-107.
} 
purposes of this contribution the dissenting opinion is the most interesting part because it explicitly frames some issues of the case in terms of racial stereotypes and compares them to gender stereotypes. In fact, the dissenting judges state that:

[I]n this context, the paramount concern of a human rights court should be whether such criteria have the disparate adverse impact of a stereotype on a minority group, no less important than the actual individual impact, which in every case is absolutely necessary for victim status to obtain. The difference in the treatment of a group raises fundamental human rights concerns, especially if it reflects or reinforces existing patterns of social stereotyping related to one or other 'natural feature'. It is impossible to think of Article 14 of the Convention as permitting second-class citizenship, especially within the ambit of Convention rights (such as those consolidated in Article 8). Indirect discrimination is unrelated to legislative intent, therefore in such cases there is no need to prove discriminatory intent. It exists, and it remains impermissible, even if it burdens disparately only a group that is differentiated on a specific ground. There is no way to justify discrimination, even if indirect, where it is to a 'decisive extent' based on a person's ethnic or national origin (see paragraph 9 below).$^{75}$

The first step was thus linking this case to the ECtHR's indirect (race) discrimination case $\operatorname{law}^{76}$ and by demonstrating how the Danish rules have a disparate racial impact on foreigners who are more often than not of different racial or ethnic origin. The stereotype reasoning comes in at a second step, namely the justification provided for introducing such a different treatment. According to the dissenters, " $\mathrm{t}]$ he concern was that, among the relevant population, there was "a widespread marriage pattern to marry a person from their countries of origin", this being understood for all practical purposes as reflecting a lack of integration. The impugned differentiation reflects and reinforces, albeit indirectly, a negative stereotype'. ${ }^{77}$ However, the ECtHR had already held that general assumptions or prevailing social attitudes in a particular country provided insufficient justification for a difference in treatment on the ground of $\operatorname{sex},{ }^{78}$ the reason why, according to the dissenters, 'similar concerns should apply to immigrant minorities' ${ }^{79}$

What this dissenting opinion shows is how anti-stereotyping reasoning, combined with the concept of indirect discrimination, can offer new understandings and new grounds on deconstructing certain aspects of the racial contract through human rights law. On the one hand, this allows closing the existing gap between racial stereotypes and gender stereotypes and, on the other hand, of explicitly acknowledging the role they play in race discrimination.

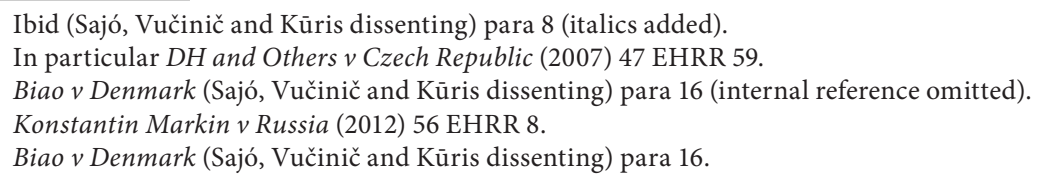


In conclusion, this contribution has attempted to map the ways in which stereotypes are (or are not) relevant in international human rights law. So far, I argue that there is a limited, inconsistent and implicit recognition of the role they play in justifying and maintaining race discrimination. Only the specialised bodies fighting against such discrimination do address the issue explicitly, albeit mostly in non-binding recommendations. The comparison with gender stereotypes and recent case law by the ECtHR indicate some way forward in changing this picture. 



\title{
THE HEAD OF THE WOMAN IS THE MAN
}

\author{
The Failure to Address Gender \\ Stereotypes in the Legal Procedures \\ around the Dutch SGP
}

\author{
Rikki HoltmaAt ${ }^{*}$
}

The theme of this volume, eradicating harmful stereotypes with the help of law, goes to the heart of my academic work in the past two decades. The stubbornness and the detrimental effects of gender stereotypes inspired me to search for legal norms that are available and appropriate to tackle such stereotypes. I have written extensively on this issue, in particular in relation to Article 5(a) of the Convention on the Elimination of all Forms of Discrimination Against Women (CEDAW). ${ }^{1}$ The first part of this provision entails the obligation of States Parties to effectively put an end to prejudices and all customs and practices which are based on the idea of the inferiority or the superiority of either of the sexes or on stereotyped roles for men and women. In the second part, States Parties are encouraged to promote a different (than traditional) understanding of the parental roles of men and women. According to the Committee of experts that supervises the implementation of CEDAW, gender stereotypes and fixed parental gender roles are root causes of discrimination against women. The elimination of all forms of discrimination

I am most grateful to my assistant Paul Post who conducted a thorough review of the first draft of this chapter and to my honours class students Habiba Bellagia, Maria Klomp and Kim van Muiswinkel for assembling and analysing the vast amount of materials on the SGP cases. SGP is the abbreviation for Staatkundig Gereformeerde Partij (see text infra n 13).

1 See for example Rikki Holtmaat, Towards Different Law and Public Policy (Reed Business Information 2004); Rikki Holtmaat, 'Preventing Violence Against Women. The Due Diligence Standard and Article 5(a) CEDAW' in Carin Benninger-Budel (ed), Due Diligence and its Application to Protect Women from Violence (Martinus Nijhoff Publishers 2008); Rikki Holtmaat, 'Article 5' in Marsha A Freeman, Christine Chinkin and Beate Rudolf, The UN Convention on the Elimination of All Forms of Discrimination against Women: a Commentary (OUP 2012); and Rikki Holtmaat, 'CEDAW: A Holistic Approach to Women's Equality and Freedom' in A Hellum and H Sinding-Assen (eds), Women's Human Rights: CEDAW in International, Regional and National Law (CUP 2013). 
against women is impossible without eradicating these causes. ${ }^{2}$ The Committee uses various terms to express this concern. For example, it states that stereotypes are 'adverse cultural norms', ${ }^{3}$ that they 'constitute barriers', ${ }^{4}$ and that they form 'the most serious obstacles', ${ }^{5}$ or 'are a root cause of the disadvantaged position of women'. ${ }^{6}$ Sometimes the Committee considers stereotypes to be discriminatory per se. ${ }^{7}$ In its Concluding Observations on Burundi in 2008, the Committee adopted both approaches in one comment. ${ }^{8}$

It is certainly positive that the CEDAW Committee has systematically stressed the discriminatory nature of gender stereotypes, and that this insight has also been accepted elsewhere in international law, as well as in case law of for example the Supreme Court of the United States. ${ }^{9}$ However, this does not mean that gender stereotypes are always recognised and revealed by the parties in legal procedures in which a violation of women's human rights is at stake, or by the judges that adjudicate such cases. ${ }^{10}$ Recognition of stereotyping is often also lacking in legal procedures that revolve around women's right to equality or nondiscrimination. ${ }^{11}$ Is it possible that the legal framing of 'women's human rights violations' as 'sex equality issues' contributes to the invisibility of the underlying gender stereotypes, and that a claim for legal equality therefore is not the most suitable strategy to address and redress such stereotypes? 'While feminist appeals

$2 \quad$ Already in 1987 the Committee adopted a General Recommendation (No 3) on Article 5. It should be noted that the General Recommendations and the Concluding Observations of this Committee are not binding upon the States Parties. However, they may be considered as an authoritative source of interpretation of the Convention. See about the role of the Committee I Boerefijn, 'Article 17' in Freeman et al (eds) (n 1).

3 Concluding Observations Madagascar, CEDAW/C/MDG/CO/5 (2008) para 16.

4 Concluding Observations Cook Islands, CEDAW/C/COK/CO/1 (2007) para 28.

5 Concluding Observations Cyprus, CEDAW/C/CYP/CO/1-2 (1996) para 45.

6 Concluding Observation New Zealand, CEDAW/C/NZL/CO/6 (2007) para 22.

7 Concluding Observation Guinea, CEDAW/C/EST/GIN/CO/6 (2007) para 23.

8 Concluding Observation Burundi, CEDAW/C/BDI/CO/4 (2008) para 17. The Committee held that it 'continues to be concerned about the persistence of patriarchal attitudes and deeprooted stereotypes regarding the role and responsibilities of men and women in society, which discriminate against women. The Committee is also concerned that the preservation of negative cultural practices and traditional attitudes serves to perpetuate women's subordination in the family and society and constitutes a serious obstacle to women's enjoyment of their fundamental rights.'

9 See eg CESCR, 'General Comment 16’ (2005) UN Doc E/C.12/2005/4, para 14; and CESCR, 'General Comment 20' (2009) UN Doc E/C.12/GC/20, para 20. A wording similar to Article 5(a) CEDAW can for example be found in the Convention of Belém do Para, Articles 7(e) and 8(b); the Protocol to the Banjul Charter on the Rights of Women in Africa, Articles 2(2), 4(d), 6 and 13. The discriminatory nature of gender stereotypes has also been acknowledged in some important court cases, eg by the US Supreme Court in Price Waterhouse v Hopkins, 490 US 228 (1989). See Rebecca Cook and Suzanne Cusack, Gender Stereotyping; Transnational Legal Perspectives (University of Pennsylvania Press 2010).

10 As far as the case law of the ECtHR is concerned, this has been analysed in depth by Alexandra Timmer in her PhD research project at Ghent University; see in particular Alexandra Timmer, 'Towards an Anti-Stereotyping Approach for the European Court of Human Rights' (2011) 11 HRLR 707.

11 Timmer therefore argues in favour of improving the equality analysis of courts, specifically the ECtHR. See Timmer (n 10). 
to equality have been rhetorically useful ... they have proved problematic in practice, and produced either limited or counterproductive results for women. ${ }^{\text {'2 }}$ Is framing women's human rights as claims for legal (sex) equality by definition problematic, or is it possible to use that legal framework in order to put an end to gender stereotyping? And if not, is there a way of legally constructing controversies or conflicts in such a way that the equality framework is avoided?

In an attempt to further develop my thoughts on this topic, ${ }^{13}$ I will discuss the case of the Staatkundig Gereformeerde Partij (Reformed Political Party, SGP), an orthodox protestant Calvinist political party in the Netherlands that up to 2013 denied women their right to participate in political life on the basis of a traditionalist-fundamentalist reading of the Bible. This patriarchal standpoint of the SGP was legally contested by several persons and organisations as violating women's right to equality, in particular their right to equality in respect to political participation. My finding in this chapter is that legally construing the SGP's exclusion of women from political participation as an issue of unequal treatment of women, to a large extent stood in the way of effectively addressing the gender stereotypes at stake in these procedures. However, there is one exception to this finding, showing that, provided that judges are aware of the detrimental role of stereotypes, law can contribute to eradicating them.

This chapter consists of three main sections. Section 1 explains the position of the SGP and describes the (fourteen!) legal procedures that took place between 1993 and 2012 around its founding principle that women should/could not have a right to participate in political life. Section 2 subsequently analyses the options that were theoretically available to legally construct the case and describes the consequences of the chosen construction of 'unequal treatment of women'. This construction, it will be shown, has led to neglecting the fact that the SGP's ideology was based on gender stereotypes in all but one of these fourteen legal procedures. Section 3 then discusses the metaphor of conflicting fundamental rights that played a pivotal role in the legal discourse surrounding these procedures and in the procedures themselves. In the framework of the legal test whether the SGP's patriarchal policies and practices could be justified, lawyers used the language of conflicting, colliding, or clashing rights that should be weighed or balanced by the judge. In what way do these metaphors frame our way of thinking about the nature and possible outcome of cases such as the SGP case? Are other metaphors perhaps better suited to discuss the issue at hand? Finally, in the Conclusion, the question whether and how law or legal procedures could play a role in combating

12 Rosemary Hunter, 'Introduction: Feminism and Equality' in Rosemary Hunter, Rethinking Equality Projects in Law. Feminist Challenges (Hart Publishing 2008) 8.

13 See earlier work arguing that other law needs to be developed, instead of claiming rights equal to those possessed by men. See Rikki Holtmaat, 'The Power of Legal Concepts: the Development of a Feminist Theory of Law' (1989) 5 Intl J Soc L 481; and Rikki Holtmaat, 'Van Gelijke Behandeling naar Ander Recht' in Eva Brems and Liesbet Stevens (eds), Recht en Gender in België (Die Keure 2011). 
(gender) stereotypes is re-examined in the light of my findings about the SGP cases. The most simple and straightforward solution would be to firmly hold on to the idea that human rights are destined for all, ie are 'universal', and that therefore no inroads on this universality principle are possible, but this stance is not accepted in legal doctrine; in practice we need to work with the (formal) equality principle. Although still rare, there are some examples of how Courts can use that legal framework in order to address and redress gender stereotypes. In the last part of the Conclusion, it is suggested that the metaphors of conflicting, colliding, or clashing rights should be replaced by different metaphors that are more suited to imagine less damaging forms of conflict resolution.

\section{THE SGP: ITS ORIGINS AND PRINCIPLES, AND THE POLITICAL AND LEGAL RESPONSES TO ITS DISCRIMINATORY POLICY}

How could a political party continue openly denying women's equal right to political participation for almost three quarters of the $20^{\text {th }}$ century, before this practice was seriously contested as a violation of women's human rights? And who contested the SGP's right to follow, to the detriment of women, their religious beliefs in this respect, and which legal basis was chosen for this contestation? In this part of the chapter, first the historical background of the SGP is explained. Subsequently, the position of the Dutch government as regards the SGP's stance on women's rights is discussed. ${ }^{14}$ Finally, four types of legal procedures that revolved around the SGP are distinguished and briefly described.

\subsection{THE SGP: ITS ORIGINS AND PRINCIPLES}

The SGP was founded in 1918 after a political accord was reached by liberal and Christian political parties that were represented in the (then all-male) Dutch

\footnotetext{
There is extensive Dutch-language literature on this party and the legal procedures concerning its denial of women's right to political participation. See (in English) I Boerefijn, 'The Right to Political Participation. The Case of the SGP' in Rikki Holtmaat and I Boerefijn (eds), Women's Human Rights and Culture/Religion/Tradition: International standards as guidelines for the discussion? Proceedings of the Colloquium in the Peace Palace, The Hague 12 May 2009 (SIM 2010); Barbara Oomen, 'Between Rights Talk and Bible Speak: The Implementation of Equal Treatment Legislation in Orthodox Reformed Communities in The Netherlands' (2011) 33 HRQ 175; and Barbara Oomen, J Guijt and M Ploeg, 'CEDAW, the Bible and the State of the Netherlands: the struggle over orthodox women's political participation and their responses' (2010) 6 Utrecht LR 158. From the perspective of CEDAW, the case is discussed by S Wittkopp, 'Article 7' in Freeman et al (eds) (n 1). The history of the SGP and some of the legal procedures concerning its policy are also described in the (inadmissible) case before the European Court of Human Rights, SGP $v$ the Netherlands no. 58369/10 (ECtHR, 20 July 2012), published in NJ 2012/478 and AB 2012, 334.
} 
Parliament. ${ }^{15}$ The deal provided that, in return for the acceptance by Christian political parties of the introduction of universal suffrage for men and women, the Christian part of the population would gain a constitutionally guaranteed right to found schools and get State funding on a basis of equality with 'neutral' schools. ${ }^{16}$ Some orthodox Christians fiercely rejected this trade-off because of the introduction of female suffrage, and therefore decided to found their own political party, the SGP.

The SGP is a theocratic party, representing a considerable minority of around 250,000 persons belonging to a particular strand of orthodox Calvinism. ${ }^{17}$ Most of these people live in rather secluded communities in the so-called Bible Belt (stretching from the south-west to the central east of the country), and adhere to very strict behavioural rules. These rules include a prohibition to engage in any activities on Sundays apart from going to church, as well as particular dress codes, especially for women. The SGP is described as a party believing in the absolute authority of the Word of God over all areas of societal life. The SGP rejects the idea of absolute equality of human beings, which it sees as false teaching of the French Revolution. In essence, the SGP believes that, although all human beings are of equal value as God's creatures, differences in nature, talents and place in society should be recognised. ${ }^{18}$

From the very beginning, the party's principles and political programme included the principle of women's and men's difference as regards their respective roles in life. According to the SGP, the Bible tells us that the man is the head of the woman and that a woman's role is to be obedient to man. This idea is amongst others based on 1 Corinthians 11, verse 3: 'But I would have you know, that the head of every man is Christ; and the head of the woman is the man; and the head of Christ is God.' It is derived from this verse that women cannot hold any kind of public office. This is expressed in the party's byelaws:

\section{Article 7}

The Word of God holds that, on the basis of the order of creation, man and woman have each been given their own and distinct mission and place. In this order the man is the head of the woman. ... Every effort at emancipation that negates the God-given mission and place of men and women is considered revolutionary and has to be combated forcefully.

15 See M Braun, 'Staatkundig gereformeerde gewetensnood: beginselvastheid door de eeuwen heen’ (1994) Nemesis 12.

16 Currently Article 23 of the Dutch Constitution.

17 Oomen et al, 'CEDAW' (n 14) 162-64; Oomen, 'Between rights talk' (n 14). SGP leadership does not describe the party as being theocratic; nevertheless, the byelaws of the Party contain the principle that the Party strives for a political and social order that is based on Biblical principles and the Party does not acknowledge any normative order above God's Word.

18 SGP v the Netherlands no. 58369/10 (ECtHR, 20 July 2012), NJ 2012, 478; AB 2012, 334, para 8. 


\section{Article 10}

The notion of [the existence of] a right to vote for women which results from a revolutionary striving for emancipation is incompatible with woman's calling. The latter equally holds true for the participation of women in both representative and administrative political organs. Women shall be led by their consciences as regards the question whether casting their vote is in accordance with their Godgiven place. ${ }^{19}$

For the (male) SGP leadership it was a matter of principle that women could and should not participate in political life. However, after some time the SGP gave up its resistance to women casting their vote during elections and declared that this was an issue of women's personal conscience. It may be assumed that this was allowed because without women's votes the party would not be able to get enough support to be represented in Parliament. The founders of the SGP considered it so obvious that women could not become members that this was not included in the party's byelaws. ${ }^{20}$ This altered in the beginning of the 1990 s after some local SGP branches had accepted women as members, which was subsequently contested by a majority of other local branches. Female party membership became impossible after a change of the party's internal rules in 1993, which were subsequently formalised in its byelaws in 1997. Women, from then on, could only apply for 'special membership', which gave them a kind of observer status, having no right to vote about internal party affairs or internal rules and regulations or to be eligible for committees or the general board. Female members were also not eligible for a place on the SGP's election lists. Only in 2007 did the SGP formally enable full female membership. ${ }^{21}$ However, the party leadership publicly declared that it would still be impossible for women to represent the party in any democratically elected forum or to hold any public office on its behalf. The SGP thus still denied women the right to stand for elections, and defended this position through almost two decades (between 1993 and 2012), during which the party was involved in as many as fourteen legal procedures.

19 The translation of these provisions has been derived from SGP $v$ the Netherlands no. 58369/10 (ECtHR 20 July 2012), NJ 2012, 478; AB 2012, 334, para 7-9.

20 Comparably, in the Dutch Constitution of 1882, it was not deemed necessary to explain that only male 'Nederlanders' (Dutch persons) could vote or be elected. After an attempt (in vain) of the Dutch feminist Aletta Jacobs to get elected to the Local Council of Amsterdam in 1883, the Constitution of 1887 explicitly reserved the right to vote or to be elected to men.

${ }_{21}$ In response to the judgment of the Hague Court of Appeal 20 December 2007, ECLI: NL:GHSGR:2007:BC0619, NJ 2008, 133, in which it was decided that the SGP's policy was discriminatory against women and that the Dutch State was therefore obliged to take action. 


\subsection{THE POSITION OF THE DUTCH GOVERNMENT AS REGARDS THE SGP}

The Dutch government has been reluctant to address the exclusion of women by the SGP. ${ }^{22}$ Although the SGP's policy is a clear case of sex discrimination based on patriarchal religious views, it nevertheless continued to exist in the context of a Dutch legal order that progressively recognised women's legal equality. ${ }^{23}$ Until the end of the 1970s, although internally this issue was debated at regular intervals, there was hardly any public debate about the SGP's continuing discrimination against women. Partly this may be due to the fact that the SGP never gained more than a few seats in Parliament. ${ }^{24}$ Neither the Dutch Constitution nor any formal act imposes any substantive requirements on the founding of a political party, or on the right to receive State subsidies for their political work. In fact, the only requirement under the law for party subsidies is that a party may not have been convicted by a court under the prohibition of discrimination in the Dutch Criminal Code. ${ }^{25}$

The question whether the SGP's policy was acceptable from a human rights perspective was for the first time openly raised in the debates during the twelve years that it took the Dutch Parliament to ratify CEDAW (from 1979 to 1991). In these debates several Christian parties expressed their concern about the possible impact of the adoption of CEDAW on the SGP and asked the Government to make a reservation to Article 7. However, the Government assured these parties that the Convention left enough room for a restrictive implementation of the State's obligations at this point 'because the right to equality needs to be balanced against other freedom rights. ${ }^{26}$ The Dutch Government, although on some occasions

$22 \quad$ See on this issue I Boerefijn (n 14).

23 This process was slow after the right to passive (in 1917) and active (in 1919) political participation was gained. Only in 1956 women gained full legal civil rights. After that it took until the mid-1970s to gain the right to equal pay, the right to equal access to employment and the right not to be dismissed because of or during pregnancy. In 1983, the right to nondiscrimination on the ground of (inter alia) sex was for the first time explicitly included in the Dutch Constitution.

24 However, the SGP was rather influential and sometimes even dominant in some Provincial and Local Councils thereby being able to set their own 'Biblical' standards in these communities. For example, in many Bible Belt villages no swimming pools were available, men and women had to swim separately, or swimming was prohibited on Sundays. At the national level, the SGP became very influential in the years 2010-2012, when their votes were decisive to keep the minority government Rutte I in power.

25 This is different from many other countries in Europe where at least the requirement exists that a political party should fully abide by the Constitutional guarantees of human rights or the right to equality or non-discrimination.

26 See the reports that were exchanged between the Government and Parliament: Kamerstukken II 1986/87, 18 950, (R1281), 3, 8 and 11; Kamerstukken II 1986/87, 18 950, 6, 5-6, 16 and 30; Kamerstukken II 1986/87, 18 950, 9, 15. See also the minutes of the oral debates in Parliament: Handelingen II, 26 June 1990, 82-4614-4615 and Handelingen II, 3 July 1990, 85-4848. The debate was held again in the framework of the adoption of the General Equal Treatment Act; see Handelingen II, 10 February 1993, 47-3507 and 47-3523. See on this J Hes and C van Vleuten, 
acknowledging that the SGP's policy was indeed discriminatory, ${ }^{27}$ consequently refused to take effective action - maintaining that CEDAW allowed for a margin of discretion about how to implement the non-discrimination principle in the light of other fundamental rights at stake. ${ }^{28}$

After the Convention had been ratified in $1991,{ }^{29}$ the 'SGP issue', as it had become known by then, was raised in the context of the Dutch reporting to the CEDAW Committee. The Government itself never mentioned the existence of this discriminatory political party in its reports. Women's rights and human rights NGOs drew the attention of the Committee to this situation in a Shadow Report that was submitted on the basis of the Second and Third Dutch Country Report; ${ }^{30}$ these Country Reports were discussed by the Committee in 2001. In its Concluding Observations, the Committee pointed out that allowing the SGP's discriminatory policy constituted a violation of the Convention. ${ }^{31}$ It repeated this stance in 2007. ${ }^{32}$ The Committee's critical position drew some attention in the academic legal press, ${ }^{33}$ but it did not in any way alter the Government's position in this regard. ${ }^{34}$ The Government maintained its argument that CEDAW allowed for a 'balancing of rights', in all legal procedures revolving around the SGP in which the Dutch State was directly or indirectly involved. It is now time to turn to these procedures and describe who instigated them and what their outcome was.

Het Vrouwenverdrag in de Nederlandse rechtsorde (Ministry of Social Affairs and Employment 1996) 89-90; L Groenman, C van Vleuten, R Holtmaat, T van Dijk and JHJ de Wildt, Het vrouwenverdrag in Nederland anno 1997 (Ministry of Social Affairs and Employment 1997) 81-85.

27 eg State Secretary of Social Affairs and Employment Ter Veld in the Parliamentary discussions about the ratification of CEDAW, Handelingen II, 3 July 1990, 85-4848.

28 See for an overview of the reaction of the Government on the CEDAW Committee's Comments, I Boerefijn (n 14) 130. The Government's estimation of the possibilities to justify unequal treatment of women under Article 7 was followed by all instances in the court proceedings, with the exception of the Regional Court of The Hague (see below), as was predicted by L Lijnzaad, 'Het kussen van een kikker' (1991) Nemesis 5, 13.

29 See the Kingdom Act of 3 July 1991 for the Ratification of the CEDAW-Convention (New York, 18 December 1979), Staatsblad 1991, 355.

30 See Defective Acceleration; Shadow Report on the Second and Third Dutch Government's Report to the CEDAW Committee, to be discussed at the $25^{\text {th }}$ Session of the Committee (E-Quality 2000) <www.atria.nl/epublications/IAV_B00077823.pdf> accessed on 22 March 2015.

31 Concluding Observations the Netherlands, CEDAW/C/NLD/CO/2-3 para 196.

32 Concluding Observations the Netherlands, CEDAW/C/NLD/CO/4 paras 25-26. The Committee, in para 25, expresses its concern about the fact that the State decided to launch an appeal against the 2005 District Court judgment in which it was ordered to withdraw the subsidy of the SG.

33 See eg C Flinterman and M Shuteriqi, 'De Staatkunding Gerformeerde Partij, vrouwen en het recht' (2002) 27 NJCM-Bulletin 336; M de Blois, 'De Mannenpartij en het Vrouwenverdrag' (2002) 18 Nemesis 173.

34 Letter dated 1 October 2001 from State Secretary of Social Affairs and Employment Verstand to the Second Chamber, Kamerstukken II 2001/02, SZW00-825. 


\subsection{LEGAL PROCEDURES AGAINST THE SGP AND AGAINST THE DUTCH STATE SUPPORTING THE SGP}

Between 1993 and 2012, as many as fourteen legal proceedings have been initiated by individual women, by feminist and human rights NGOs, and by the SGP itself, in all branches and at all levels of the Dutch legal system, finally resulting in a complaint by the SGP itself at the European Court of Human Rights (ECtHR) in Strasbourg. These procedures can be divided into four categories:

(1) $1993-2001:{ }^{35}$ several proceedings against the SGP were initiated by individual women who wanted to gain full party membership and who stated that the SGP's policy amounted to discrimination against women.

(2) 2004-2005: a coalition of NGOs brought a civil public interest lawsuit against the SGP in order to force the party leadership to change the party's rules or byelaws and to accept female membership/female candidates on election lists.

(3) 2004-2010: the same coalition of NGOs brought civil public interest lawsuits against the Dutch State in order to force the State to take action to enforce women's equal right to political participation.

(4) 2006-2012: the SGP itself instigated several court procedures in response to actions of the third type and the subsequent actions taken by the Dutch government on the basis of judgments in those procedures, culminating in the application to the ECtHR. ${ }^{36}$

The first type of legal action was fruitless. All individual women who started lawsuits against the SGP because of the discriminatory nature of the SGP's policy and/or because they wanted to fully and equally participate in that political party (because this party best represented their world view), were either declared to be inadmissible, or lost their cases. ${ }^{37}$ In 1993, around twenty women made official complaints at a police station about discrimination by the SGP, but the public prosecutor dismissed these complaints because the exclusion of women from political participation was/is not a criminal offence under Dutch criminal law. ${ }^{38}$ In an appeal to this decision of the prosecutor, the Appeal Court also reached the

\footnotetext{
35 In 2010-2011 another individual tried to prevent the registration of the SGP for the national elections by making a formal complaint at the Electoral Council, which was declared inadmissible by the highest administrative court. See Administrative Jurisdiction Division of the Council of State (ABRvS) 27 January 2011, ECLI:NL:RVS:2011:BP2851, AB 2011, 105. Since there is little information available about the identity of the individual and the substantive motivations in this procedure, I will not take it into consideration in my analysis.

36 The procedures of type 2, 3 and 4 and their outcomes are summarised in SGP $v$ the Netherlands App no 58369/10 (ECtHR, 20 July 2012), NJ 2012, 478; AB 2012, 334, para 14-50.

37 See on these cases also Titia Loenen, 'De SGP-discussie revisited' (2010) Nederlands Juristenblad 2269.

$38 \quad$ A Mattijssen, 'Wordt (niet) vervolgd?' (1993) 9 Nemesis 172; and the press release of the Public Prosecution Service, 'SGP wordt niet vervolgd' (1995) 11 Nemesis 158.
} 
conclusion that the SGP's exclusion of women did not amount to discrimination in the sense of the existing criminal law provisions. ${ }^{39}$

One woman instigated a civil lawsuit against the SGP to claim admission to the party, but also lost her case. It was found that she could not prove that she really desired membership of this political party, for she did not declare that she fully subscribed to the SGP's reading of the Bible, in particular their reading as regards women's role in life. ${ }^{40}$ Two complaints, furthermore, were issued at the Equal Treatment Commission, but this Commission concluded that the existing equal treatment legislation did not cover the area of political functions and political associations. ${ }^{41}$ One woman who was a member of the reformed protestant community, Ms Grabijn-Van Putten, very persistently tried to get access to party membership, but in the end gave up because she was threatened and harassed by members of her own community. ${ }^{42}$ Another woman, Ms Franssen, was also very persistent to get the SGP convicted for discrimination against women; she was involved in the criminal, the civil and the equal treatment route, all in vain. ${ }^{43}$ In short, for individual women who tried to change the SGP's policy 'from within' no effective legal remedies were apparently available. ${ }^{44}$

The second type of legal action was also fruitless. In the early 2000 s, a civil public interest lawsuit was brought against the SGP by a coalition of feminist and human rights NGOs. This coalition was deemed inadmissible by the court, mainly because it was unable to prove that it actually represented individual 'SGP women'. ${ }^{45}$

The third type of legal action was eventually successful. In various procedures against the Dutch State, the same coalition of NGOs that brought a public interest

(1)

The Hague Court of Appeal 30 November 1995, ECLI:NL:GHSGR:1995:AD2441, NJ 1996, 324. District Court The Hague 1 November 1995, RN 1996, 539.

Equal Treatment Commission 30 December 1994, Decision 1994-16 and Decision 1994-17; Equal Treatment Commission 21 December 2001, Decision 2001-150. The Equal Treatment Commission is a pseudo-juridical, tribunal-type equality body that dealt with complaints under the (civil law) unequal treatment legislation. From 1 October 2012 onwards, the ETC has been replaced by the Netherlands Institute for Human Rights (NIHR).

R Grabijn-van Putten wrote about her experiences in her booklet Ik wil het gewoon vertellen (Boekencentrum 1996). See also M van Amerongen, 'Riet Grabijn-van Putten' in De Groene Amsterdammer 10 July 1996, <www.groene.nl/1996/28/riet-grabijn-van-putten> accessed 14 June 2015.

43 Mrs Franssen was involved in the procedures leading to the decision of the Regional Court The Hague not to instigate criminal proceedings against the SGP (District Court The Hague 30 November 2006, ECLI:NL:RBSGR:2006:AZ5393), in the first civil law (tort) case against the SGP (District Court The Hague 1 November 1995, RN 1996, 539); and in the first case before Equal Treatment Commission (Equal Treatment Commission 30 December 1994, Decision 1994-16).

44 Against this background, the reproach, made by many commentators and even judges, that the coalition of NGOs had no business in interfering with the SGP's internal affairs and that the women in the SGP should and could come forward themselves to claim their rights, is rather peculiar. See for this stance for example Oomen, 'Between Rights Talk' (n 14).

45 District Court The Hague 7 September 2005, ECLI:NL:RBSGR:2005:AU2091, NJ 2005, 474. The coalition did lodge an appeal against this judgment, but did not actively continue this lawsuit against the SGP, after which the Appeal Court struck the case out of its list. 
lawsuit against the SGP was admitted as acting in the name of the general interest. The general interest in these cases was that Dutch society should be free from discrimination against women. It was therefore proposed that the State could not financially support a party that openly discriminated.

In 2005, the District Court of The Hague ordered the Dutch State to cease its subsidies for the SGP's party organisation. ${ }^{46}$ The State and the SGP both appealed against this decision. The Court of Appeal in The Hague (in 2007) ${ }^{47}$ and the Supreme Court (in 2010) ${ }^{48}$ both agreed with the District Court's finding that Article 7 CEDAW has direct effect in the Dutch legal order and that the SGP was discriminating women (as is prohibited in inter alia Article 7(c) CEDAW). The State was ordered to take appropriate and effective measures to address this discrimination of women. ${ }^{49}$ The Court of Appeal and the Supreme Court did not rule on the kind of action that should be taken. In terms of the separation of powers in a democratic State, it was deemed not the task for the judiciary to tell the State which measures it should take; thus the State had a discretionary power to decide what would be the most appropriate action to put an end to the SGP's discriminatory policy. ${ }^{50}$ This meant that after six years of legal proceedings, in 2010 the coalition of NGOs had finally won its case insofar that the Dutch State was held accountable for allowing the SGP to breach Article 7(c) of CEDAW.

The fourth type of legal action consisted of legal procedures brought by the SGP itself against the Dutch State. The State's decision not to subsidise the SGP after the 2005 District Court judgment, was in the end successfully appealed by the SGP in an administrative law procedure. After the SGP lost its lawsuit against the State in first instance, ${ }^{51}$ the Administrative Jurisdiction Division of the Council of State by contrast held that the Law on Party Subsidies did not offer sufficient grounds to refuse the SGP financial support. ${ }^{52}$ The withdrawal of the subsidy, from that perspective, was illegal. ${ }^{53}$

$46 \quad$ District Court The Hague 7 September 2005, ECLI:NL:RBSGR:2005:AU2088, NJ 2005, 473.

47 The Hague Court of Appeal 20 December 2007, ECLI:NL:GHSGR:2007:BC0619, NJ 2008, 133.

48 Supreme Court of the Netherlands 9 April 2010, ECLI:NL:HR:2010BK4547, NJ 2010, 388; AB 2010, 190.

49 The Supreme Court's judgment was heavily debated in the press as well as in the legal academic literature. See eg S van Bijsterveld, 'Het passief kiesrecht, de staat en de SGP' (2010) 1 TRRB 81; Loenen (n 37); and R Schutgens and J Sillen, 'De SGP, het rechterlijk bevel en het kiesrecht' (2010) NJB 1114. Annotations on this judgment appeared in inter alia NJ 2010, 388 (Alkema); AB 2010, 189 (Van Ommeren); and Gemeentestem 2010, 63 (Broeksteeg).

50 In fact, the Dutch State, after the 2010 Supreme Court judgment, merely declared to wait and see whether the SGP would bring an application to the ECtHR. See C Flintermann and I Lintel, 'Vrouwen verkiesbaar bij de SGP: een kwestie van tijd en politiek?' (2011) NJB 2029.

51 District Court The Hague 30 November 2006, ECLI:NL:RBSGR:2006:AZ5393.

52 Administrative Jurisdiction Division of the Council of State (ABRvS) 5 December 2007, ECLI:NL:RVS:2007, AB 2008, 35.

53 The Administrative Jurisdiction Division of the Council of State also gave several other arguments for its decision, which was made under the guise of a 'weighing of interests and rights' by this Court. 
Furthermore, the SGP submitted a complaint to the ECtHR after the 2010 Supreme Court's judgment that ordered the Dutch State to take appropriate and effective measures to address the discrimination of women by the SGP. According to the SGP, this judgment violated the right to freedom of religion, freedom of expression and freedom of association. The ECtHR held (simply put) that there was nothing wrong with the Dutch Supreme Court judgment and, in an inadmissibility decision, declared the SGP's complaint manifestly ill-founded. ${ }^{54}$

The judgment of the Supreme Court and the decision of the ECtHR were considered a victory for the feminist and human rights NGOs, who thought that the Dutch government now finally had to take effective action against this political party. However, it was still not in hurry to do so. ${ }^{55}$ It was only after a 'good conversation' with the government that, in 2013, the SGP's General Assembly voted in favour of allowing women to be eligible for being a candidate on the Party's election lists. ${ }^{56}$ In March 2014, for the very first time in its history, a woman stood candidate for the SGP, winning a seat in the Local Council of Vlissingen. Finally, after almost twenty years of various types of court procedures, change had been achieved..$^{57}$

\section{THE CONSTRUCTION OF THE LEGAL PROBLEM AS AN ISSUE OF UNEQUAL TREATMENT OF WOMEN}

This section analyses the legal construction of the procedures that were described above. What would, at least in theory, have been the options to legally construct or 'frame' the cases against the SGP and/or against the State? It appears that the legal norm of equal treatment of men and women was the focal point of all legal procedures and of the academic and political discourses surrounding the SGP's exclusion of women. As a consequence of the focus on unequal treatment of women, three issues became important: comparability, disadvantage, and justifications for the unequal treatment. In the latter context,

$54 \quad$ SGP $v$ the Netherlands no 58369/10 (ECtHR, 20 July 2012), NJ 2012, 478; AB 2012, 334. The ECtHR also considered that in fact the SGP was not a victim of any violation of the ECHR because the State had as yet not taken any action against the party.

55 Letter dated 12 October 2012 of the Minister of Interior to the Second Chamber, Kamerstukken II $2012-13,28$ 481, no 19.

56 See an article in Dutch daily NRC Handelsblad <www.nrc.nl/nieuws/2013/03/16/politiekongeschikt-maar-vooruit-vrouwen-mogen-van-de-sgp-op-de-kieslijst/> accessed 15 June 2015. After this development, the Minister of Interior announced that no further action on the basis of the Supreme Court's judgment was necessary. See Kamerstukken 2012-13, 28 481, no 20 .

57 It is debated whether the court procedures in fact hastened or slowed down this process. Oomen argued that the Court proceedings by the coalition of NGOs against the SGP only led to a strengthening of the belief of the SGP constituency that their position was 'right'. See in particular Oomen et al, 'CEDAW' (n 14). 
the main point of dispute became one of 'clashing fundamental rights' and of a weighing or balancing of women's right to equality against other fundamental rights. However, the fact that the SGP's ideology is an example par excellence of gender stereotyping, apparently did not put any weight in the scales. Only the inadmissibility decision of the ECtHR forms an exception to this rule. In the last part of this section I will therefore analyse how this Court, within the framework of application of the formal equality principle, did effectively address the gender stereotypes that underlie the SGP's patriarchal ideology.

\subsection{FOUR DIFFERENT POSSIBILITIES TO LEGALLY ADDRESS THE SGP'S POLICY TO EXCLUDE WOMEN FROM POLITICAL PARTICIPATION}

The issue of the exclusion by the SGP of women from membership and on their election lists can be constructed as a legal issue in at least four different ways. ${ }^{58}$

(1) The beliefs and practices concerning the exclusion of women of the SGP (the SGP policy) amount to a denial of the fundamental right to political participation of women. Under international human rights law all human beings have the right to active and passive political participation. These human rights documents further specify that these rights exist without distinction. ${ }^{59}$ States Parties to these Treaties have a negative duty not to interfere with these rights; and, most importantly, a positive duty to ensure that these rights can be enjoyed effectively by all who are formally eligible (eg on the basis of their nationality, citizenship or age). ${ }^{60}$ In the Netherlands, the right to active and passive political participation is laid down in Article 4 of the Constitution,

58 See about the fact that any 'story' allows to be transformed into a particular 'legal issue' in many different ways S Baer, 'A Closer Look at Law: Human Rights as Multi-level Sites of Struggles over Multi-dimensional Equality' (2010) 6 Utrecht LR 56. Baer, at 63, calls this the tendency to fetishise the law. She contends, at 63: 'Then, discussions of conflicts in human rights focus on court decisions which react to insular claims, again reduced to an abstract narrative of "key" facts and "the" law applicable thereto. ... Then it is "cases" which are discussed, rather than "experience", and "cases" seem to be clear, while experience is personal, ambivalent, shifting, contextual, where details matter.' She concludes, at 74: 'Finally there is this tendency to fetishise the law, to frame complex problems as binary clashes, to disregard multilevel regulation and the richness of norms which may inform a solution to a problem.'

59 See inter alia Articles 1 jo 55 UN Charter; Article 2 ICCPR; Article 2(2) ICESCR; and Article 14 ECHR. The latter right is explicitly accessory (it guarantees that the rights under the Convention can be enjoyed without discrimination), but nevertheless got a free-standing meaning; as a consequence the ECtHR 'balances' this right against other Convention Rights. See A Stuart, 'Without distinction - a defining principle?' in E Brems (ed), Conflicts between Fundamental Rights (Intersentia 2008) 111ff.

60 The positive duty to ensure that fundamental human rights are ensured 'without distinction' can also be derived from the more specific non-discrimination treaties, such as CERD, CEDAW and CRPD. 
which stipulates expressly that these rights belong to all Dutch nationals on a basis of equality.

(2) The policy of the SGP amounts to unequal treatment of women as compared to men; women do not have the right to be a full party member and/or to represent the community in elected political bodies and in public offices while men do have these rights. In legal terms: the SGP's policy is violating several international legal norms/human rights provisions in which women's right to equal treatment has been laid down, most notably Article 7(c) CEDAW. ${ }^{61}$ In terms of national law: the SGP's policy amounts to a violation of the prohibition of discrimination as enshrined in the Dutch Constitution. ${ }^{62}$ The equal treatment or non-discrimination norm has also been laid down in criminal law and in equal treatment laws; ${ }^{63}$ however, these laws do not cover the area of political participation.

(3) Women belonging to traditional SGP communities and/or women in the wider orthodox Protestant communities from which the SGP derives its support, have the right to take part in all aspects of the formation and practising of their (religious) beliefs, customs and practices and to act as spokespersons for these communities. In the words of Article 13(c) CEDAW, women have the right to 'participate in ... all aspect of cultural life' on the 'basis of equality between men and women'. For this international right, no equivalent exists under Dutch law. However, since the Netherlands has a monist system, such a transposition in Dutch law is not necessary, provided that the international norm is clear and precise enough to be applied directly in the Dutch legal order; which in this case is debatable.

(4) The policy of the SGP amounts to gender stereotyping because it reflects a deeply rooted, religiously inspired ideology about the different roles of men and women in life. In legal terms, the SGP's policy as regards women amounts to - in the words of Article 5(a) of CEDAW - 'prejudices and customary and all other practices which are based on the idea of the inferiority or the superiority of either of the sexes or on stereotyped roles for men and women'. Although the SGP, as well as the reformed protestant community in which it is based, has the freedom to adhere to such an ideology, ${ }^{64}$ the Dutch State is under an international legal obligation to put an end to the practice. For

61 Invoking CEDAW in procedures against the SGP is problematic because the SGP is not a party to these human rights treaties and is therefore not directly bound by the norms that they entail. Therefore, this provision in fact only played a role in the third type of legal actions against the SGP's policy, ie holding the Dutch State accountable for allowing this violation of women's right to equality by means of subsidising the SGP.

62 Although it is recognised that this constitutional provision can have horizontal effect, it was not successfully invoked in the procedures of types 1 and 2 .

63 In particular Article $137 \mathrm{f}$ of the Criminal Code and the General Equal Treatment Act of 1994.

64 This freedom of conscience or political conviction is guaranteed under international law, but always under the restriction that the rights and interests of others are nor disproportionately affected. 
this international right, there is also no equivalent under Dutch law. Again, transposition is not a condition for applicability of this norm, provided that it is considered to be clear and precise enough; which in this case is also debatable.

The difference between the first and second conceptualisation of the issue may appear to be a matter of nuance or may even seem trivial, but in fact is crucial. When the human right to vote and to be elected are put central in the construction of a legal issue that is put before the court, the question of whether there is equality when granting these rights becomes an essential normative feature of that right as such. The right to political participation exists as a human right for all; denying that right to a particular group of people is by definition unacceptable. Equality, in that perspective, is a crucial feature of the right that is invoked; without equality this right does not even exist. In the words of Stuart: 'It is contended that the non-discrimination norm was designed to shape the content of each human right internally so as to guarantee that human rights were ensured without distinction. The norm [of non-distinction] cannot therefore be used in an external balancing process. It is part, and foundation, of each human right. ${ }^{36}$ She continues to remark that ' $\mathrm{t}$ ] he duty on the state to ensure human rights without distinction is a stark and simple one. In none of the multiple references to it is there any mention of an allowable limitation to that right. ${ }^{36}$ This is very different in the free standing human right to non-discrimination: this 'right to equality' is open to bring forward 'objective justifications'.

The construction of a legal case against the SGP and/or the Dutch State, as a violation of the norms laid down in inter alia Article 5 and Article 13 of CEDAW, is problematic as long as these norms are deemed to be of a too general and programmatic nature to be invoked in a concrete legal dispute and as long as no transposition in Dutch law has taken place. ${ }^{67}$ However, Article 5 CEDAW could and should be invoked as interpretative tool for any of the other rights at stake (in our case: the right to political participation).$^{68}$ In its General Recommendation No 28 the Committee made it clear that, on the basis of Article 2(c), 'States parties must ensure that courts are bound to apply the principle of equality as embodied in the Convention and to interpret the law, to the maximum extent possible, in

\footnotetext{
Stuart (n 59) 102.

Ibid 106.

The norms in CEDAW, for a very long time, were seen as 'programmatic' by Dutch courts. In that sense, it was a victory of the coalition of NGOs that at least the civil courts, including the Supreme Court, accepted that Article 7 did have direct effect in the Dutch legal order.

68 Article 5 is placed in the part of the Convention that contains the general obligations of the States Parties. This means that it should play a role in the interpretation and implementation of all substantive Convention rights. See Christine Chinkin and Marsha A Freeman, 'Introduction' in Freeman et al (eds) (n 1) 8.
} 
line with the obligations of States parties under the Convention. ${ }^{39}$ As regards the right to political participation, it is of crucial importance that the Committee, in General Recommendation No 23, made explicit reference to the detrimental effects of gender stereotypes for women's realisation of their political rights:

In all nations, the most significant factors inhibiting women's ability to participate in public life have been the cultural framework of values and religious beliefs, the lack of services and men's failure to share the tasks associated with the organisation of the household and with the care and raising of children. In all nations, cultural traditions and religious beliefs have played a part in confining women to the private spheres of activity and excluding them from active participation in public life. $^{70}$

Although at some points the Dutch courts did show awareness of the existence of this General Recommendation, ${ }^{71}$ its content, in particular in relation to gender stereotyping, did not make any difference in the way they evaluated and weighed the various rights that were invoked in the case.

In addition to the use of Article 5 in the construction of the legal issue, Article 13 could and should have been used to argue that women belonging to traditional SGP communities and/or women in the wider orthodox Protestant communities from which the SGP derives its support, have the right to take part in all aspects of the formation and practising of their (religious) beliefs, customs and practices and to act as spokespersons for these communities. ${ }^{72}$ On the basis of Article 13 the stance of the male leadership of the SGP, ie that only they were capable of speaking on behalf of this religious community, could and should have been contested. According to Shaheed, giving women a voice about how they interpret their belief and how they experience particular traditional or religious practices is a prerequisite for the correct implementation of the human right to culture. ${ }^{73}$ Another possible consequence of including this right into the construction of the case is the avoidance of granting fundamental rights, such as the right to freedom of political association, to the SGP as a group, instead of to

\footnotetext{
69 CEDAW Committee, General Recommendation 28 on the Core Obligations of States Parties under Article 2, para 33.

70 CEDAW Committee, General Recommendation 23 on Political and Public Life, para 10.

71 See in particular District Court The Hague 7 September 2005, ECLI:NL:RBSGR:2005:AU2088, NJ 2005, 473, in the case of the coalition against the Dutch State, para 3.21, quoting from CEDAW, General Recommendation 23, paras 32-34.

72 This seems to be an argument of Loenen in her comment on the Supreme Court judgment of 2010, although she does not mention this provision of CEDAW. See Loenen (n 37). See on the content and scope of women's right to cultural participation the report on gender and cultural rights by UN Special Rapporteur on Cultural Rights, F Shaheed, Report to the UN General Assembly 10 August 2012, UN A/67/287. 
individual believers and citizens. ${ }^{74}$ As for cultural and religious rights, frequently the claim is made that these rights belong to the cultural or religious group as such, thus - in the words of Baer - often amounting to 'groupism':

Whenever a 'culture' or a 'religion' claims recognition, we have the problem of reification, in that this suggests that the culture or religion is homogenous. We also usually have the problem of elitism, since and when such collective claims are not defined by all members of the relevant entity. ${ }^{75}$

In the legal cases revolving around the SGP, the fact that no individual woman from that community was actually represented by the coalition of NGOs and the fact that (some) SGP women had openly declared that they did not want to support legal procedures against this party was deemed to be problematic. The civil public interest lawsuit brought against the SGP by the coalition was therefore deemed inadmissible by the court. ${ }^{76}$ In this case, it was presented as a fact that SGP women preferred to discuss the issue internally. ${ }^{77}$ However, none of the courts, nor any of the academics writing on the topic, directly contested the ability and authority of the SGP all male leadership to represent 'their' women in these court procedures. According to the UN Special Rapporteur on Cultural Rights, 'whenever "gender-biased social arrangements are defended in the name of culture, the purported cultural norms need to be challenged", by asking, inter alia ... whether these norms are representative of the community, or are simply a generalization of the narrow interests of a few; and whose power is preserved through the use of the purported cultural norms?'78 Clearly, that did not happen in the cases revolving around the SGP.

\subsection{THE CONSTRUCTION OF THE SGP'S POLICY AS A CASE OF UNEQUAL TREATMENT OF WOMEN}

As regards the choice between the first and second possible way of constructing an issue of equality in relation to a human rights violation, Stuart notes that human rights treaty bodies and other judicial bodies have 'rather than treating

\footnotetext{
${ }_{74} \quad$ On the topic of cultural rights as individual human rights, see Y Donders, Towards a Right to Cultural Identity? (Antwerp 2002); and Y Donders, 'The Legal Framework of the Right to Take Part in Cultural Life' in Y Donders and V Volodin (eds), Human Rights in Education, Science and Culture (Unesco 2007).

75 Baer (n 58) 59. In this quote she refers to R Brubacker, Ethnicity without Groups (HUP 2006). Baer, at 60 , warns against legal recognition of group rights, since 'a collective freedom tends to trump individual rights.'

76 District Court The Hague 7 September 2005, ECLI:NL:RBSGR:2005:AU2091, NJ 2005, 474.

77 Ibid para 3.9. See Oomen et al, 'CEDAW' (n 14), who describe this preference of the SGP women for internal discussion.

78 UN Special Rapporteur on Cultural Rights (n 72), para 68 (reference omitted).
} 
the non-discrimination norm as integral to, and part of, each human right, [have] separated the duty not to discriminate in the fulfilment of each human right, from the development of the scope of the duty to ensure them without distinction, and treated the non-discrimination norm as a substantive human right to be balanced alongside any other human right. ${ }^{79}$ This tendency is clearly visible in the SGP cases ${ }^{80}$ In practice, in all four types of legal proceedings revolving around the SGP's policy of exclusion of women, the second construction or 'legal framing' of this situation prevailed to the exclusion of the other three possibilities, ie the central argument of the claimants was that the unequal treatment of women (as compared to men) by the SGP was prohibited under (international and/or national) law and/ or that the State should put an end to that unequal treatment or at least not support it any longer. ${ }^{81}$

The SGP's stance on the role of women was seen as a violation of women's human right to have access to all aspects of political participation 'on a basis of equality with men' as laid down in (inter alia) Article 7(c) CEDAW. This means, that the 'separate equality norm' became applicable, the consequences of which will be discussed below. Another feature of this construction of the legal issue was that Article 7 was invoked without putting that provision in the context of Articles 5(a) and 13(c) CEDAW, or in the context of the general object and purpose of the Convention as such. ${ }^{82}$ As a result, the principle of equality as included in CEDAW was read in a rather formalistic way, not taking into account the fact that the Convention (for example in Articles 3 and 4) also appeals to States Parties to actively contribute to enhancing women's de facto equality and to see equality as a transformative principle. ${ }^{83}$

What is striking when analysing the extensive case law and academic literature that resulted from the legal procedures around the SGP, is that neither the claimants in the procedures (particularly the coalition of NGOs), nor the judges, nor any of the academic commentators on this case law in any way directly addressed the underlying patriarchal ideology of this party as being

Stuart (n 59) 101.

80 See on this general tendency to rephrase almost every anti-oppression or anti-exclusion claim made by feminists into an equality claim, Holtmaat, 'Van Gelijke Behandeling' (n 13). See for a critique of the 'equality paradigm' in law also Hunter (ed) (n 12).

81 I made this latter argument myself in my only (published) contribution in all these years to the legal debate surrounding the SGP's policy. See Rikki Holtmaat, 'Wèl het opgeheven vingertje, maar niet de hand in eigen boezem' (2001) NJB 2001 1800. There, I argued that the most appropriate action against the SGP would be to (try to) get a court order in which the State would be compelled to stop subsidising this political party.

82 See Holtmaat, 'CEDAW' (n 1). On this omission, I wrote an article together with Alexandra Timmer: 'De SGP-zaak anders bekeken. Maar een holistische uitleg van artikel 7 VN-Vrouwenverdrag' (2011) 36 NTM/NJCM-bulletin, 445.

83 On the transformative potential of CEDAW, see S Fredman, 'Beyond the dichotomy of formal and substantive equality. Towards new definitions of equal rights' in I Boerefijn et al (eds), Temporary special measures. Accelerating de facto equality of women under article 4(1) UN Convention on the Elimination of all forms of Discrimination Against Women (Intersentia 2003). 
discriminatory against women in itself. ${ }^{84}$ The primordial claim was that the actual practices of the SGP (the refusal to admit women as members and the refusal to put women on the election lists) based on this patriarchal belief amounted to unequal treatment of women as compared to men; women did not have the right to full party membership and/or to represent their religious community in elected political bodies and in public offices, while men did have these rights. In legal terms: the SGP's policy was violating several international legal norms/ human rights provisions in which women's right to equal treatment has been laid down, most notably Article 7(c) CEDAW. The legal framing of an issue as a matter of unequal treatment (in this case on the ground of sex) has serious implications for the way a Court will analyse or test whether indeed the legal norm of equal treatment or non-discrimination has been violated. ${ }^{85}$ In particular, issues of comparability, disadvantage and justification have proven to be important 'hurdles' in this test, as is also visible in the SGP cases.

The requirements of comparability and the existence of a disadvantage and the possibility to bring forward objective justifications.

The first result of framing something as an issue of unequal treatment on the ground of sex is that it immediately raises questions about the comparability of men and women: are women in this regard (in this case: political participation) indeed comparable, ie 'equal' to men?86 This opens the door to bring forward (presumed or 'real') differences between men and women, like biological, reproductive differences. Or, as in the case of the SGP, the fact that the Bible ascribes very different characteristics and roles to men and women, which roles are seen as 'God-given' and therefore unchangeable. ${ }^{87}$ The SGP consistently

84 With the exception of the ECtHR in the very last stage of the proceedings. See the last part of this section. A reason for not openly addressing/redressing the SGP's patriarchal ideology could be that in discrimination law there is a general tendency to only prohibit concrete acts/ deeds, not the ideas or ideologies that inspire these deeds, at least not when they are not openly provoking violence against protected groups (hate speech and incitement to discriminatory violence as prohibited forms of discrimination). This may be due to the very strong protection that the freedom of thought and the freedom of expression have gained in international human rights law; in particular when this 'expression' is related to religion. An example of this hesitance to prohibit speech acts is the fact that in Dutch criminal law sexist speech acts (eg in commercial advertising) are not prohibited. See on this division between 'acts' and 'speech acts', Judith Butler, 'Performative Acts and Gender Constitution; An Essay in Phenomenology and Feminist Theory' (1988) 40 Theatre Journal 519.

85 There is extensive literature on the construction of this test. See in particular Janneke Gerards, Judicial Review in Equal Treatment Cases (Martinus Nijhoff Publishers 2005).

86 Although formally being two different issues, the question whether there is comparability in many cases gets easily mixed up with the question whether there is a justification. See Gerards (n 85). See also S Moreau, 'Equality Rights and the Relevance of Comparator Groups' (2006) 5 JL\&Equality 81 . One of the main problems with comparability in a formal equal treatment claim is that this requirement tends to reinforce gender stereotypes: the claimant has to compare her position with the position of the defendant, who can state to be relevantly different on the basis of existing gender roles or stereotypes.

87 Often descriptive and prescriptive stereotypes about the differences between men and women are interwoven. See on this topic Cook and Cusack (n 9). 
argued that although men and women are of equal worth and dignity, they are not equal or similar and therefore equal treatment is not called for. Although this argument was not accepted by the courts, it was also not contested or rejected as not viable (or 'void') in the light of the principles expressed in the international treaties that guarantee human rights for all.

The second result of this way of framing the issue is that it implies that some or all women in the Netherlands have been done injustice to because they have experienced the disadvantage of having been denied benefits or having been subjected to particular burdens that are unfavourable for them as compared to the treatment given to men. Often this requirement is an obstacle for women since the existence of an actual disadvantage is difficult to prove. ${ }^{88}$ In the SGP cases, due to this requirement an individual reformed protestant woman lost her civil law case, for she had not proven that she actually fully subscribed to the SGP's founding principles and because she was free to become a member of another party or to found her own party. Therefore, she was not supposed to be disadvantaged by the SGP's exclusion of women. In the coalition's cases against the SGP and the State, the same argument was made by the SGP and the Dutch State: women in the Netherlands were, supposedly, not in any way disadvantaged by the SGP's policy because they were free to either become members of other political parties or to found their own new party. ${ }^{89}$ In particular women belonging to Dutch reformed protestant communities were supposedly not disadvantaged because it was assumed that they themselves also adhered to the same interpretation of the Bible as not allowing women to 'govern over men'. And even if they would not adhere to this belief any longer, it was possible for them to found a new political party on the basis of their own interpretation of the Bible. ${ }^{90}$

Here, the difference with the first possible construction of the legal issue, as described above, becomes very visible. From the perspective of the fundamental human right to participate in the democratic process, women and men are equal. This right is enshrined in the Dutch Constitution and in many international human rights treaties. Comparability or actually being 'similarly situated' and

88 For that reason, some scholars argue that not causing disadvantage but causing harm should be the standard. For example, sexual harassment does not cause a disadvantage for women as compared to men, but is harmful in the sense of violating women's dignity. This is visible in the different definition of direct and indirect discrimination as compared to the definition of (sexual) harassment in the EU (Recast) Sex Equality Directive. See Article 2 of Directive 2006/54/EC of the European Parliament and of the Council of 5 July 2006 on the implementation of the principle of equal opportunities and equal treatment of men and women in matters of employment and occupation (recast), OJ L204/23.

89 This argument was not accepted by the judges in the civil law cases of the coalition of NGOs against the Dutch State, but it did play a role in the way the Administrative Jurisdiction Division of the Council of State balanced the interests involved in the administrative law case of the SGP against the State when its subsidy was withdrawn.

90 This argument was very important in the judgment of the highest administrative court, the Administrative Jurisdiction Division of the Council of State (ABRvS) 5 December 2007, ECLI:NL:RVS:2007, AB 2008, 35. 
/ or having experienced a disadvantage as compared to men is not at all an issue when the legal issue is framed as a human rights violation. The right to equality is part and parcel of the right to political participation and cannot and should not be separated from it. In the words of Stuart, 'the non-distinction norm delineates the content of each human right'. ${ }^{91}$

Alternative ways of constructing a disadvantage were absent in this equality framing. Is the disadvantage, injustice or harm that Dutch women, or more specifically Dutch reformed protestant women, experienced as a consequence of the policy of the SGP, really that men possessed something that women did not possess? Or is perhaps the harm done to the women who are member of that Protestant community that, apparently, they do not have the freedom to decide what is the proper role for a woman, and are denied the possibility to define what it means (for them) to be a woman? And could the harm done to them not also be that they apparently (according to the SGP Party's byelaws) are not in a position to co-decide what exactly the Bible entails in this regards? (Article 13(c) of CEDAW) Although they are a member of the reformed protestant community and want to stay a member of that community, they may want to bring forward and effectuate a different understanding of the Bible, one that does not exclude women from active political work as a party representative in elected organs of the democratic society. ${ }^{92}$ And is it not harmful more generally (to Dutch women and men) that the Dutch State allows for the existence and even subsidises a party that stereotypes women according to patriarchal norms? Should the legal question not have been whether, or to what extent, the State has an obligation under Article 2(f) in conjunction with Article 5(a) CEDAW to put an end to this policy of the SGP, or at least not to support it any longer by means of granting subsidies to this political party?

The third, and in my view most important consequence of framing an issue as 'unequal treatment on the ground of sex', is that this construction opens the door for the defendant(s) to bring objective justifications. ${ }^{93}$ In the case of the SGP, the rights to religious freedom and/or freedom of political association were brought forward (both by the SGP and the Dutch State) as justifications for the SGP's policy as regards women and for the State's support to this political party. In particular in the legal proceedings of the coalition of NGOs and the SGP itself

$\overline{91 \quad \text { Stuart (n 59) } 121 .}$.

92 There is some evidence that quite a few women who belong to the SGP's traditional constituency had different opinions, but preferred to have that discussion internally, instead of by means of a legal procedure that was instigated by feminist outsiders. See Oomen et al, 'CEDAW' (n 14). There is also evidence that at least one woman did, in vain, try to change the party from within, then opted for legal procedures, but in the end had to give up because of serious intimidations from the side of other members of her community. See Grabbijn van Putten (n 42).

93 This is because, at least at the level of international human rights law (eg Art 14 ECHR) and Dutch constitutional law, the (separate) prohibition of unequal treatment is not absolute, but may be 'objectively justified' when there is a legitimate aim and the means to achieve that aim (ie the unequal treatment) are proportional, ie appropriate and necessary. 
against the Dutch State, ${ }^{94}$ the debates focussed on the question to what extent the State could or should limit fundamental freedoms of the SGP in order to uphold the principle of sex equality.

In this regard, there is again a crucial difference between the first and the second possible legal construction of the issue. The argument that the rights to religious freedom and/or to freedom of (political) association would be violated if the SGP were to be compelled to accept women as members of the party, is not valid (or even irrelevant) from the perspective that the fundamental right to political participation belongs to all human beings, without any exception. Weighing or balancing the right to equality against other 'conflicting' rights that are brought forward by way of justification for the unequal treatment is therefore not appropriate, according to Stuart: 'As the non-distinction norm delineates the content of each human right, it is misleading to talk about there being a clash between the non-distinction norm and a substantive human right as if they were human rights of equal weight. ${ }^{\prime 95}$

In the context of the SGP cases there was a lot of critique about whether the right to equality was by definition an 'absolute' right, which was (implicitly) the stance of the coalition in their pleas. ${ }^{96}$ In fact, the stance taken by Stuart was not accepted by any of the participants in the legal and political discourse surrounding the SGP court cases. The issue was constructed from the very beginning not as a matter of the right to political participation per se, which right belongs to all, but as a matter of unequal treatment of women in respect to this right. The possibility to bring forward justifications for the unequal treatment by the SGP, in the form of an appeal to other rights or interests on the side of the SGP, was deemed in principle possible by almost all judges and academic commentators, because 'the right to equality cannot automatically prevail over other fundamental rights. ${ }^{\prime 97}$ The only exception was the District Court of The Hague in the civil law suit of the coalition of NGOs against the Dutch State, which decided that the drafters of CEDAW had already made the assessment which right should prevail and that therefore there was no room for any balancing or weighing of other rights or interests, at least not in case a political party was involved in the conflict. This was the most far-reaching decision in this regard, which left no room for justifications in this particular equality case. On the basis of an examination of the travaux préparatoires of Article 7, the District Court concluded that the drafters of CEDAW did not intend to make the right to equality in general superior to the

\footnotetext{
94 The cases described under types 3 and 4 in section 1 of this chapter. In cases of types 1 and 2 the balancing act did not take place because these cases were deemed inadmissible or were lost for other reasons.

$95 \quad$ Stuart (n 59) 121.

96 The coalition did not phrase it as such, but stated that the principle of sex-equality should outweigh other possible rights or interests (based on papers submitted to the Courts by the coalition; on file with the author).

97 This was a recurring statement, both in the judgments and in the annotations and academic articles that were published in reaction to them.
} 
right to freedom of association; this was different, however, in the situation where political parties were involved. Besides, the Dutch State had made no reservation to this article; therefore the right to equality should prevail. ${ }^{98}$ This judgment, however, was fiercely criticised by several commentators, ${ }^{99}$ and was subsequently reversed as regards that particular part of its reasoning in the judgments of the Appeal Court and the Supreme Court.

Although the coalition of NGOs in the end won the case against the State, the question whether the State somehow was under a duty under Article 5(a) CEDAW to modify/eliminate the patriarchal views and practices of this political party, or were under a duty under Article 13(c) CEDAW to effectively guarantee protestant women to co-determine the content of their own religious 'culture', was never raised. In that sense, the legal arguments that were put in the judges' scales to be weighed or balanced against the fundamental rights of the SGP were definitely incomplete. ${ }^{100}$

\subsection{THE IMPOSSIBILITY OF JUSTIFYING DISCRIMINATION AGAINST WOMEN WITH AN APPEAL TO TRADITIONAL GENDER ROLES}

Only one court explicitly addressed this political party's patriarchal ideology and declared that it is not legally possible to justify the exclusion of women from the enjoyment of a (human) right solely with a call upon such an ideology. After the Dutch State had lost its Supreme Court case against the coalition of NGOs, the SGP complained in Strasbourg that the State (by means of this judgment alone) had violated its rights under the Convention. Although the case was declared inadmissible, the principles expressed by the ECtHR in this document are very important.

Firstly, the ECtHR has some notable things to say about the relationship between the right to political participation for all and the concept of democracy. ${ }^{101}$ Secondly, the issue of the patriarchal values underlying the SGP's policy was finally

\footnotetext{
$98 \quad$ See also Boerefijn (n 14) 126-27.

99 District Court The Hague 7 September 2005, ECLI:NL:RBSGR:2005:AU2088, NJ 2005, 473. Annotations appeared in AB 2005, 398 (Kanne and Nehmelman), NJCM-Bulletin 2005, 8 (De Blois and Loenen). See also H Dölle, 'De SGP onder vuur' in Jaarboek Documentatiecentrum Nederlandse Politieke Partijen 2005 (DNPP 2006); M Busstra, 'De afweging afgewogen' (2008) 6 Themis 235; G Leenknegt, 'Het gelijkheidsbeginsel en de scheppingsorde: een staatsrechtelijke botsproef', (2005) 54 AA 659.

100 In section 3 I will return to the metaphors that are predominantly used in this 'balancing' or 'weighing' discourse.

101 See paras $69-71$ of this judgment. In particular, the Court reiterates (in para 71) 'that a political party may, under the Convention, pursue its political aims on two conditions: firstly, the means used to those ends must be legal and democratic; secondly, the changes proposed must themselves be compatible with fundamental democratic principles (see Refah Partisi and Others, cited above, $\$ 98)$.'
} 
addressed by this human rights Court, although only in one brief and rather cryptic paragraph. After having confirmed (in para 72) that 'the advancement of the equality of the sexes is today a major goal in the member States of the Council of Europe' and that 'very weighty reasons would have to be advanced before a difference of treatment on the ground of sex could be regarded as compatible with the Convention', the Court, in para 73 continues:

Moreover, the Court has held that nowadays the advancement of the equality of the sexes in the member States of the Council of Europe prevents the State from lending its support to views of the man's role as primordial and the woman's as secondary.

The ECtHR at this point inter alia refers to the Grand Chamber judgment in Konstantin Markin.$^{102}$ In order to understand how the Court applies the principle of formal equality here, it is useful to have a brief look at that judgment. In Konstantin Markin, the ECtHR makes it clear that, as far as justifications for unequal treatment are concerned:

[I]n particular, references to traditions, general assumptions or prevailing social attitudes in a particular country are insufficient justification for a difference in treatment on grounds of sex. For example, States are prevented from imposing traditions that derive from the man's primordial role and the woman's secondary role in the family. ${ }^{103}$

Assessing the case of the applicant Markin, a military serviceman who had no statutory right to three years' parental leave while servicewomen were entitled to such leave, the Court concludes (para 143):

that the reference to the traditional distribution of gender roles in society cannot justify the exclusion of men, including servicemen, from the entitlement to parental leave. The Court agrees with the Chamber that gender stereotypes, such as the perception of women as primary child-carers and men as primary breadwinners, cannot, by themselves, be considered to amount to sufficient justification for a difference in treatment, any more than similar stereotypes based on race, origin, colour or sexual orientation.

The ECtHR, contrary to the Dutch courts in the SGP cases, is sensitive to the underlying gender stereotypes of certain (different or unequal) rights granted to

\footnotetext{
$102 \quad$ Konstantin Markin v Russia App no 30078/06 (ECtHR [GC], 22 March 2012). See on this case in relation to the issue of gender stereotyping, Alexandra Timmer, 'From inclusion to transformation: rewriting Konstantin Markin v. Russia' in Eva Brems (ed), Diversity and European Human Rights. Rewriting Judgments of the ECHR (CUP 2013).

103 Konstantin Markin v Russia App no 30078/06 (ECtHR [GC], 22 March 2012) para 127.
} 
men and women, and uses this knowledge to clearly point out that such ideologies or traditional values cannot justify any unequal treatment between the sexes. Without explicitly mentioning it, the ECtHR applies a norm that was already broadly accepted in international human rights law long before this judgment. ${ }^{104}$

\section{THE METAPHORS USED IN THE JUSTIFICATION TEST IN SEX-EQUALITY CASES}

This section briefly addresses the detrimental effects of using the language of 'conflicting rights'. This language is predominant in any situation where it is argued that women have a right to equal treatment, but where the other party - due to the fact that it is possible to bring forward objective justifications appeals to one or more other fundamental rights that in this party's view are at stake. The first part of this section will explain that the language of 'conflicting rights' should not be taken literally, but that the words used in that context are metaphors - metaphors, in fact, with disastrous effects. The second part of this section considers the possibility of replacing these metaphors with less damaging, alternatives.

\subsection{THE DISASTROUS LANGUAGE OF CONFLICTING RIGHTS}

Application of the objective justification test in discrimination cases implies that other interests may be brought forward that (in the view of the defendant) legitimise the inequality of treatment. In this way a dualistic/oppositional scheme of women's human rights or of women's right to equality versus other fundamental rights, like the freedom of expression, the freedom of religion, or the freedom of association is constructed. This 'conflict of fundamental rights' 105 becomes most poignant when an opposition between on the one hand women's right to equality and on the other hand the freedom of religion or freedom of conscience is constructed, as was the situation in the SGP cases. ${ }^{106}$ This means

\footnotetext{
104 See for various sources confirming this 'principle' R Holtmaat and J Naber, Women's Human Rights and Culture; From Deadlock to Dialogue (Intersentia 2011) 47-49.

105 See on the topic of conflicting human rights S Smet, Resolving Conflicts Between Human Rights; A Legal Theoretical Analysis in the Context of the ECHR, PhD Dissertation University Ghent, 2013-2014. In any situation where inroads on the full enjoyment of the human right by an individual may be justified (ie where limitations of the rights are deemed possible), this issue may arise. Smet's research shows that such conflicts in particular arise between the right to family life or privacy and the right to freedom of expression, and between the right to equality and the right to freedom of religion. See about the conflicts between the last two rights also A McGolgan, Discrimination, Equality and the Law (Hart Publishing 2014), Chapter 5.

106 See T Loenen, W van Rossum and Jet Tigchelaar, 'Human Rights Law as a site for struggle over multicultural conflicts' (2010) 6 Utrecht Law Review 10, who note that often these rights
} 
that, as a consequence of constructing the legal issues surrounding the SGP's exclusion of women as an issue of in principle justifiable unequal treatment of women, the controversy from the very beginning was also framed as an issue of 'opposed', 'competing', 'incommensurable', 'conflicting', 'colliding' or even 'clashing' fundamental rights. ${ }^{107}$ Subsequently, the debate resulted in a firm deadlock between these fundamental rights. ${ }^{108}$

A link appears to exist between usage of the frame of a right to equal treatment and the language of conflicting rights: as soon as something is framed as an issue of (un)equal rights between men and women, it also becomes possible, and often unavoidable, to frame that same issue in terms of conflicting etc. rights, between which in the end the judiciary needs to make a choice. Which right should carry most weight: women's right to equal treatment or the SGP's right to religious freedom or freedom of (political party) association? This image of weighing or balancing of interests or rights is very familiar to lawyers. ${ }^{109}$ It has an appearance of neutrality and objectivity that in fact hides the hidden normative assumptions behind each of these rights. Baer points out that any such 'clashing rights' discourse is based on the belief that legal rights do have a fixed and determined meaning, and are not sites for struggle over meaning: 'Any given law and any given set of rights, including human rights, are contested and, if taken seriously as sites of diverse interpretations, are not useful to mark clear collisions, ie of religious freedom and equality.'110

Baer, in this last quote, although being critical of this framework, still seems to accept that a collision between rights is possible at all. In my view, the critique of this particular legal discourse should be taken a little further. It is necessary also to criticise the metaphors that are constantly used in this discourse, up to a point that they are 'paradigmatic', ie determine our way of being able to conceive of a particular issue. Often, metaphors are used to say something general or abstract by means of making an implicit comparison with something concrete or tangible. Metaphors thus have the power to inspire people's imagination and contribute to their knowledge and understanding of the world that surrounds

are invoked in such legal conflicts, because they offer more strongholds than the vague and under determined 'cultural rights' or 'right to cultural diversity'. According to these authors the framing of multicultural issues as conflicting and opposing fundamental human rights leads to a particular construction of 'clashing' of cultural identity rights or religious rights, as opposed to women's (equal) rights.

The various metaphors used in this regard are slightly different from each other, but all of them somehow presuppose that the rights involved are 'hard' and have a stable and fixed meaning. They all invoke the image of the legal procedure as a conflict or contest with only one possible 'winner'.

108 Holtmaat and Naber (n 104).

109 It is also much criticized. In relation to the SGP cases, M Busstra argued that the fact that this balancing takes place in the framework of a justification test makes it already an 'uneven' exercise because the claimed right is 'equal treatment' and the defendant is therefore in a disadvantaged position to have to bring forward arguments why the equal treatment norm should not apply. Busstra (n 99). However, Busstra does not question the balancing act as such. Baer (n 58) 64. 
them. ${ }^{111}$ The choice of an appropriately 'functioning' metaphor is crucial. In the context of a fictional story metaphors can put people's minds on the right or on the wrong track as regards their understanding of what the story is about and how it will possibly evolve and come to a conclusion. This also applies to any other kind of story; like stories that lead to legal disputes or stories about how these legal disputes can or should be resolved. The role of metaphors in imagining a solution in legal procedures therefore deserves 'strict scrutiny'. ${ }^{112}$ To return to the image of a track: metaphors may lead us to the right conclusion, or they may put us on a carrier that is heading in the wrong direction, or even leading us into a crash with major obstacles on that track.

In legal procedures where more than one fundamental right is invoked, the metaphorical words predominantly used by practicing lawyers and legal academics to describe what is going on are 'balancing', 'weighing' and 'conflicting rights'. My thesis is that the usage of these metaphors about judges' activities and about the character of the issue that needs to be decided by the court, is not an innocent method of helping us to understand the process of legal decision making, but that it structures the way in which this legal process functions, and that it thereby co-determines its outcomes.

In particular the language used to indicate that there is a 'conflict' between rights is very problematic in my view. The term 'conflicting rights' is further specified in this legal discourse by words like 'outweighing', 'colliding', 'competing', 'clashing', 'incommensurability', and 'incompatibility'. Like the metaphor of putting rights in scales and weighing or balancing them, ${ }^{113}$ these words suggest that fundamental rights have a definite, uncontested and concrete substance or content that can 'conflict' with the substance or content of other rights. The more specific words, however, most strongly suggest that fundamental rights are 'hard'. This is certainly the case when words like collision or clash are used. Imagine what

111 See G Lakoff and M Johnson, Metaphors We Live By (University of Chicago Press 2003 [1980]).

112 Metaphors play a role in respect to law in at least four different ways. Firstly, the phenomenon of (the) law as such is often pictured as something else that is more comprehensible or concrete for most people. For example, law is seen as a body of institutions and rules that functions organically. Secondly, law itself uses metaphors when defining the content of a rather abstract or general norm. For example, the 'open' norm that everyone has the obligation to look after someone else's property 'like a good housefather'. Thirdly, metaphors are used to describe what exactly is being done by actors in the legal field, in particular what judges do. Most often used nowadays is the expression that judges are 'balancing' or 'weighing' the interests that are at stake in a particular case. A fourth metaphor in law concerns the nature of the relationship between the norms or rights that are involved in a legal case, like is the case with the metaphor of 'conflicting rights'.

113 This image of the scales of justice is in fact presupposing that judges know exactly what the weight of each right involved is. Of course they do not actually use scales in which they put interests to be weighed; they 'weigh' or 'balance' only in a manner of speaking. Interests, in fact are abstract social constructions and cannot be equated with or treated as natural objects, likes stones or cherries. The same goes for rights: they do not have a particular 'weight' and their content is contested instead of clear and fixed forever. See Baer (n 58), where I quote her objections to the language of conflicting rights. 
happens when a collision or clash between actual objects takes place; any such 'encounter' will lead to serious damage of the least 'hard' one of the two objects involved in it. Clashes or collisions cause fractures or even a 'total loss'.

The word conflict seems less disastrous in this regard. Using that word in the context of adversarial court procedures seems logical: why would people bring something before a court of justice when they do not have a conflict (over something) with each other? However, the phrase 'conflicting fundamental rights' is not referring to a conflict between the parties in the procedure, but to a conflict between the rights that are invoked by these parties. Because rights cannot argue with each other, the word conflict in this context is a metaphor. The same applies to all the other words describing the 'encounter' of the various rights involved in this kind of legal procedures. It is important to realise how metaphors help human beings understand something abstract with the help of something concrete: the image of fractures or a total loss resulting from a 'clash' between objects in real life is used to imagine the outcome of the legal procedure in which these words are being used. One of the rights involved (in the SGP cases in some instances women's equal right to political participation, in other instances the right to political association or religious freedom) has to give way to another right that 'wins' the case; the right that loses the case is 'damaged' (worth less) by the outcome of this procedure. ${ }^{114}$

\subsection{TOWARDS USING A DIFFERENT METAPHOR}

In order to avoid this rather disastrous image of what is at stake in such legal procedures, it is necessary to free ourselves from these dominant (probably even paradigmatic) metaphors about the nature of legal procedures and the role of judges in solving them, and to develop alternative ways of imagining the resolution of the issue that is brought before the court of justice. Perhaps, lawyers and judges should attend creative writing workshops in which they are stimulated to employ other, more constructive and productive, metaphors when a situation arises where more than one fundamental right is invoked by the parties in a legal procedure. One suggestion for such alternative language could be that we imagine the legal procedure as the staging of a play; or, perhaps even more adequate, as a composition (and at the same time the performance) of a piece of music in which various instruments play a part or have a voice. The instrument of the judge, in that situation, would no longer be the two balancing scales, but a synthesiser that would be used to produce a symphony that does not suppress any of the instruments or voices in the play, and that is harmonic and a pleasure to listen to

\footnotetext{
114 The metaphor of competing rights narrowly mirrors this idea of the legal procedure as a competition that can be won or lost by either of the parties.
} 
for all involved in the case. ${ }^{115}$ The resulting work of musical art (ie the judgment) would allow for women's voices, in particular about the harms done by gender stereotypes, also to be expressed and to be heard.

\section{CONCLUSION}

The analysis of the history of the SGP cases has revealed that two topics deserve further investigation, also with a view to more effectively using law for the purpose of combating gender stereotypes. The first concerns the tendency to construct violations of women's (human) rights as legal issues of unequal treatment of women and the consequences thereof. The second concerns the usage of the dominant and negative metaphor of conflicting rights in the context of the justification test that is applied in many of these unequal treatment cases.

As was shown in this chapter, issues of violations of women's human rights can be constructed in various ways. Stuart's suggestion to simply insist that human rights exist for all, and that therefore no justification of unequal treatment as regards the enjoyment of these rights is ever possible, is most often not followed in the legal construction of violations of women's human rights. ${ }^{116}$ On the contrary, most lawyers vehemently emphasise that the right to equality can never be absolute or cannot automatically trump other invoked human rights. The warnings of feminist lawyers about the way legal (sex) equality operates, and their complaints about the very limited or even detrimental effects of using the equal treatment norm to advance women's rights, are manifold, but still this norm is constantly invoked when violations of women's human rights are contested in court. ${ }^{117}$ Issues of comparability and disadvantage are major obstacles to make such claims successful, as is also demonstrated in the analysis of the SGP cases in this chapter. Moreover, the doctrinal framework of the equal treatment norm opens the door to the objective justification test, which brings a conundrum of conflicting rights into play - a situation named as one of 'conflicting' or even 'clashing' fundamental rights.

The analysis shows that constructing women's rights violations as issues of equal treatment (as compared to men) leads to a particular kind of reasoning in which these 'juridical exercises' automatically come up. From a radical feminist perspective, it would therefore be recommendable to think beyond the equality framework, or maybe even to think beyond the 'rights' framework, in particular

\footnotetext{
115 I am most grateful to Westerman, professor of legal philosophy at the University of Groningen, who in an inspiring discussion about this topic suggested this metaphor to me.

116 Stuart (n 59).

117 Critical assessments on the very limited or adverse instrumental value of liberal and formal equality law are abundant. See eg S Fredman, Discrimination Law (OUP 2011), in particular $8 \mathrm{ff}$. More and more it is acknowledged that replacing the notion of formal equality with that of substantive equality will also 'not deliver the goods'. See eg Hunter (ed) (n 12) 8.
} 
when the aim is to combat the gender stereotypes that lie behind (and cause) these human rights violations. But that recommendation, most probably, would lead out of the realm of the rights discourse and of law, as it is currently constructed. Following that route would lead to abandoning the strategy of developing a constructive and effective feminist legal jurisprudence and practice. Maybe it is indeed true, as Brown stated, that equal rights are something that 'we cannot not want to have'? ${ }^{118}$

In the context of the Dutch case law on the SGP's exclusion of women, the framing of this exclusion as an issue of women's equal rights to political participation indeed left the underlying patriarchal ideology and the gender stereotypes involved in this ideology undisputed and uncontested. Although the SGP cases thus confirmed my pessimistic feelings about using the right to equality as a basis for legal proceedings in order to enhance women's human rights and to combat gender stereotypes, the decision of the ECtHR shows that there is some light shining in that darkness: when a Court is determined to do so, it can indeed effectively address and redress beliefs, customs, practices or laws that are based on gender stereotypes. This observation is shared by some scholars who point out that in particular the principle of formal equality can be used in a constructive way to combat gender stereotypes. There is, gradually, a re-appreciation of the possibilities of using the firmly rooted concept of formal equality not only to tackle overt forms of unequal treatment between women and men, but also to combat the underlying assumptions about the different roles of men and women that have justified that difference in treatment for a long time. ${ }^{119}$ In these contributions to feminist legal theory, it is shown that - provided that the gender-biased nature of legal and social constructs is unveiled and openly contested - formal equality can deliver some positive results.

Such a re-appraisal of the principle of formal equality, in my view, deserves our full attention in the light of improving the usefulness of law in enhancing women's human rights. Greater awareness among practicing lawyers and judges of the stubbornness and detrimental effects of gender stereotypes is a crucial condition for such a progressive use of formal equality. Revealing the existence of stereotypes, and bringing them explicitly into the legal discussion about what exactly constitutes equality, is a necessary step in the process of achieving a true

118 In relation to claiming rights in the framework of liberal Western legal systems, Brown argues that - although being a mixed blessing and leading to many paradoxes we cannot not want to have rights. W Brown, 'Suffering Rights as Paradoxes' (2000) 7 Constellations 230, 231. equality by $\mathrm{N}$ and $\mathrm{R}$ Siegel and by Franklin, who discuss the positive and transformative effects - in terms of combating gender stereotypes - of a strict adherence to the principle of formal equality by US Supreme Court Justice Ruth Bader Ginsberg. N Siegel and R Siegel, 'Struck by Stereotype: Ruth Bader Ginsberg on pregnancy discrimination as sex discrimination' (2010) 59 Duke LJ 771; C Franklin, 'The Anti-Stereotyping Principle in Constitutional Sex Discrimination Law’ (2010) 85 NYLR 101. 
transformation of society. ${ }^{120}$ In addition to that, legal scholars - probably in close cooperation with 'literary' scholars - should develop a critical approach towards the metaphorical language that is used to denote and frame legal issues, such as the issue of 'conflicting fundamental rights'. Let us use our human creativity and our power of imagination to propose other concrete images that represent the abstract and almost unconceivable complex issues that are at stake when women (and men) legally contest the existing, gendered state of affairs, in order to guarantee women the full enjoyment of their human rights. Let us work together to produce a new legal symphony, one that does not silence women's voices and clearly expresses the discriminatory nature of gender stereotypes.

$\overline{120}$ See in particular the work of Cook and Cusack (n 9), and Timmer (n 10 and n 102). 



\title{
GENDER STEREOTYPING IN THE MILITARY
}

\section{Insights From Court Cases}

\author{
Rebecca Cook and Cornelia WeIss*
}

\section{INTRODUCTION}

This chapter examines how courts in different regions of the world have determined whether stereotyping of women and men in the military contributes to violations of their constitutional and human rights. The term 'stereotype' derives from the Greek words 'stereo', meaning solid, and 'type', meaning mould that imprints a picture. A gender stereotype is 'a generalized view or preconception of attributes or characteristics possessed by, or the roles that are or should be performed'1 by, women and men. Gender stereotypes are concerned with the social and cultural constructions of women and men due to their physical, biological, sexual, cognitive and social attributes. ${ }^{2}$ Stereotyping is the 'process of ascribing to an individual specific attributes, characteristics, or roles by reason only of her or his membership in a particular group. ${ }^{3}$

Understanding how women and men are stereotyped illuminates the hidden nature of gender prejudice. The pernicious effects of gender prejudice are often

* Rebecca Cook is professor emerita, Faculty of Law, University of Toronto. Cornelia Weiss is a lawyer and a colonel in the US Air Force Reserve. The opinions and views expressed are the authors' personal views and are not intended to represent in whole or in part the opinions of the US government or any of its components. We are grateful to: Michelle Hayman for her excellent research assistance, Christopher Dandeker for his timely insights on UK developments, Ariella Migdal for helpful discussions on pending US litigation, Tania Sordo Ruz for alerting us to the Colombian court decision, and Mumbi Gathoni for her assistance on Kenyan developments. We thank Simone Cusack and Ralph Earle for their perceptive insights and discussions on an earlier draft of this chapter, and anonymous reviewers for their helpful comments. We are indebted to the 2014 Women's Rights in International Law course of the Academy on Human Rights and Humanitarian Law, American University Washington College of Law for thoughtful discussions on gender stereotyping in the military.

1 Rebecca J Cook and Susanne Cusack, Gender Stereotyping: Transnational Legal Perspectives (University of Pennsylvania Press 2010) 9, 20-31.

Ibid 20.

Ibid 12 . 
invisible because their ordinariness blinds societies to such effects, like the proverbial fish that is blind to the water in which it swims. ${ }^{4}$ Stereotyping is one of the quickest ways 'that prejudice can spread and thrive': ${ }^{5}$ it is a 'technology of prejudice.' ${ }^{6}$ Stereotypes 'gain storage extra easily in the human mind and are extra easy to retrieve'?

Gender stereotyping happens in all sectors of society, but it plays a particular role in the military. It has been explained that militaries are gendered institutions. They make use of, rely on and perpetuate the assumptions that women and men not only can but must occupy different roles, and that the place which is right and proper for men to occupy is privileged above that of women. This notion of a hierarchy or a privileging of (what is construed as) the masculine over (what is construed as) the feminine is very important because it helps explain why militaries need to preserve their status as distinctively masculine institutions. ${ }^{8}$

The chapter focuses on court decisions addressing women in the military but not exclusively, because the constraining power of male stereotypes impacts women and the similar power of female stereotypes impacts men. It has been explained that ' $[n]$ otions of masculinity and femininity are created and reinforced by states, societies and militaries in a wide variety of subtle and reciprocal ways. Accepting the ideas that militaries are distinctively male entities which have nothing to do with women and that it is natural for men to become soldiers makes it easier to accept the privileging of masculinity and men over femininity and women in society at large. ${ }^{\prime 9}$

The term 'sex' in this chapter is used to refer to individuals' biological sex, and the term 'gender' is used to refer to how individuals are socially constructed. Understandings of gender are fluid and can vary according to different contexts. Women can be considered to be 'masculine' or to have masculine attributes, and men can be considered to be 'effeminate' or to have feminine qualities. What constitute masculine and feminine attributes often depends on fixed notions or stereotypes that are dominant or hegemonic. It has been explained that 'hegemonic masculinity is the ideal form and is considered to be the most respected, desired, and dominant within society'. ${ }^{10}$ Military institutions have contributed significantly, and sometimes exclusively, to the formulation of hegemonic masculinities.

\footnotetext{
$4 \quad$ Laurie A Rudman, 'Rejection of Women? Beyond Prejudice as Antipathy' in John F Dovidio, Peter Glick and Laurie A Rudman (eds), On the Nature of Prejudice: Fifty Years after Allport (Wiley-Blackwell 2005) 107, 117.

$5 \quad$ Anita Bernstein, 'What's Wrong with Stereotyping' (2013) 55 Arizona LR 665, 678. Ibid 680 .

Ibid 678 .

$8 \quad$ Jennifer G Mathers, 'Women and State Military Forces' in Carol Cohn (ed), Women \& Wars (Polity 2013) 126.

$9 \quad$ Ibid 145.

10 Tyson Smith and Michael Kimmel, 'The Hidden Discourse of Masculinity in Gender Discrimination Law’ (2005) 30(31) Signs 1827, 1831.
} 
This chapter explains how courts have served and are serving an important role in naming detrimental gender stereotypes in the armed forces, exposing their harms and in determining how they infringe constitutional and human rights. It has purposely analysed decisions from different national and regional courts because 'decisions from around the world may provide a much-needed external perspective on the myths and stereotypes that may continue to permeate the values and laws of our own communities and cultures. ${ }^{\text {'1 }}$ The chapter argues that the ways in which national and international courts are determining constitutional and human rights violations can blunt the spread of stereotyping harms, and contribute to the eradication of gender prejudices in military institutions. This chapter will analyse national and international court decisions and pending cases around the following interconnected themes:

(a) Exclusion, such as exclusion from the draft: Rostker $v$ Goldberg ${ }^{12}$ (Rostker), Alexander Dory $v$ Federal Republic of Germany ${ }^{13}$ (Dory), from full integration including combat: Gauthier v Canada (Canadian Armed Forces) ${ }^{14}$ (Gauthier), Angela Sirdar $v$ The Army Board and Secretary for Defence ${ }^{15}$ (Sirdar), Tanja Kreil v Bundesrepublik Deutschland ${ }^{16}$ (Kreil), Hegar et al v Hagel ${ }^{17}$ (Hegar), and from military training: Alice Miller $v$ Minister of Defence ${ }^{18}$ (Miller), United States $v$ Virginia ${ }^{19}$ (Virginia);

(b) Unequal treatment, including discharge for pregnancy: Struck $v$ Secretary of Defense ${ }^{20}$ (Struck), Crawford v Cushman ${ }^{21}$ (Crawford), unequal dependency benefits: Frontiero $v$ Richardson ${ }^{22}$ (Frontiero), and unequal parental leave: Konstantin Markin v Russia ${ }^{23}$ (Markin);

(c) Sexual assault, including rape, sexual assault and sexual harassment by military personnel of their comrades: Mary Gallagher et al $v$ United States of

Claire L'Heureux-Dubé, 'Beyond Myths: Equality, Impartiality and Justice' (2001) 10 Journal of Social Distress and the Homeless 87, 101.

453 US 57 (1981) (US Supreme Court).

Case C-186/01 [2003] ECR I-2508.

[1989] CHRD No 3, [1989] DCDP No 3 (Canadian Human Rights Tribunal).

Case C-273/97 [1999] ECR I-07403.

C-285/98 [2000] ECR I-00069.

C12-06005 (First amended complaint filed 31 October 2013 pending in the US District Court for the Northern District of California) <https://www.aclu.org/womens-rights/hegar-etal-v-hagel-amended-complaint $>$ accessed 8 January 2015; originally filed as Hegar et al $v$ Panetta (27 November 2012) <https://www.aclu.org/womens-rights/hegar-et-al-v-hagel> accessed 8 January 2015. See <www.defense.gov/News/News-Transcripts/Transcript-View/ Article/632578/> (3 Dec 2016) accessed 18 February 2016.

[1995] HCJ 4541/94, IsrSC 49(4) 94, IsrLR 178 (Israel Supreme Court).

518 US 515 (1996) (US Supreme Court).

460 F2d 1372 (1971) (US Court of Appeals, 9 $9^{\text {th }}$ Circuit).

531 F2d 1114 (1976) (US Court of Appeals, $2^{\text {nd }}$ Circuit).

411 US 677 (1973) (US Supreme Court).

(2012) ECHR 514. 
America and the U.S. Department of Defense $e^{24}$ (Gallagher), and of the civilian population: Rodríguez Bustamente et al v National Army/National Ministry of Defense $e^{25}$ (Rodríguez Bustamente), Ines Fernández Ortega et al v Mexico ${ }^{26}$ (Fernández Ortega).

\section{ANALYSIS OF CASES}

This section analyses how select domestic and international courts have addressed whether the social practices of gender in militaries are in compliance with their obligations under constitutional and human rights law. The term 'select' is used because this analysis does not intend to be comprehensive, but rather only an introductory overview. Other decisions are referenced where they impact issues concerning exclusion, unequal treatment or sexual assault.

Discussion of each area of case law, exclusion, unequal treatment, and sexual assault, will conclude by exploring what has been learned about how courts:

- name the degrading stereotypes prevailing in the military;

- discuss their individual and group harms; and

- determine how those harms contribute to violations of human and constitutional rights.

Particular attention will be given to how courts analyse the facts about women's actual military performance in order to better understand how courts' analyses contribute to dismantling stereotypes.

\subsection{EXCLUSION CASES}

Court cases have challenged a range of restrictions on women's military recruitment, including exclusion from the draft (Rostker, Dory), from full integration in the military including combat (Gauthier, Sirdar, Kreil, Hegar), and from military training (Miller, Virginia).

$24 \quad$ Petition filed by the Cornell International Human Rights Clinic in the Inter-American Commission on Human Rights, 23 January 2014 <www.lawschool.cornell.edu/academics/ clinicalprogram/int-human-rights/Military-Sexual-Assault-Petition-to-IACHR.cfm> accessed 8 February 2015. See also Carla Butcher et al $v$ United States of America and the US Department of Defense (Petition filed by the Cornell Global Gender Justice Clinic in the InterAmerican Commission on Human Rights, 18 January 2015) <www.lawschool.cornell.edu/ Clinical-Programs/global-gender-justice/Sexual-Assault-Continues-to-Violate-the-HumanRights-of-US-Service-Members.cfm> accessed 8 February 2015.

25 Consejo de Estado de Colombia (Council of State of Colombia) No 29033 of 9 November 2014, per Ramiro Guerrero Pazos.

26 IACtHR, Judgment of 30 August 2010, Series C No 215. 
In Rostker, the US Supreme Court held that the Military Selective Service Act's authorisation of male-only registration did not violate the constitutional due process guarantee. ${ }^{27}$ The Court explained that:

[s]ince women are excluded from combat, Congress concluded that they would not be needed in the event of a draft, and therefore decided not to register them ... Men and women, because of the combat restrictions on women, are simply not similarly situated for the purposes of a draft or registration for a draft [and therefore the male only draft registration did not] violate the Due Process Clause. ${ }^{28}$

The dissent disagreed: 'The Court today places its imprimatur on one of the most potent remaining public expressions of "ancient canards about the proper role of women"' ${ }^{29}$ The dissent explained that the male-only draft registration 'categorically excludes women from a fundamental civic obligation - inconsistent with the Constitutional guarantee of Equal Protection', ${ }^{30}$ and continued:

Legislative classifications which distribute benefits and burdens on the basis of gender carry the inherent risk of reinforcing sexual stereotypes about the 'proper place' of women and their need for special protection ... Where, as here, the [Government's] ... purposes are as well served by gender-neutral classification as one that gender classifies, and therefore carries with it the baggage of sexual stereotypes, the [Government] cannot be permitted to classify on the basis of sex. ${ }^{31}$

In line with the Rostker result, the European Court of Justice (ECJ) held in Dory that member states could restrict the draft to men. ${ }^{32}$ Because of the compulsory nature of conscription as opposed to the voluntary nature of the professional service, the ECJ considered that conscription fell outside the scope of European Community law on sex discrimination, especially the Equal Employment Directive. ${ }^{33}$ In focusing on the scope of European Community law, the ECJ regrettably avoided any discussion on the discriminatory aspects of an all-male

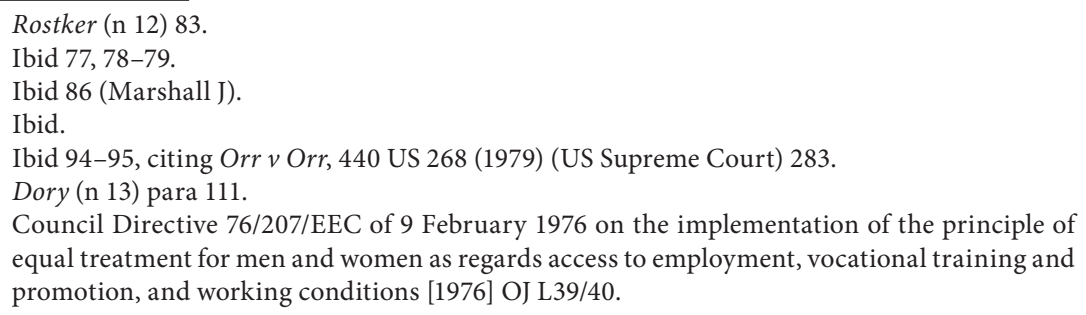


draft. ${ }^{34}$ In contrast to the US and Germany, Norway in 2015 started conscripting both men and women. ${ }^{35}$

The cases addressing exclusion from full integration in the military include Gauthier, Sirdar, Kreil and Hegar. In Gauthier, the Canadian Human Rights Tribunal addressed whether operational effectiveness of the Canadian Armed Forces (CAF) constitutes 'a bona fide occupational requirement of such a nature that the exclusion of women from combat-related occupations is justified, even though it is, on its face, a discriminatory practice. ${ }^{36}$ The three female plaintiffs argued that the categorical employment of men to the exclusion of women was not a bona fide occupational requirement for operational effectiveness. As a result, the female plaintiffs contended that the policy of excluding women from combat training and positions was unjustifiable sex discrimination under the Human Rights Act. ${ }^{37}$ The male plaintiff, a retired military pilot, argued that the exclusion of women from the risks assumed by men of flying fighter aircraft and fulfilling combat duties was sex discrimination under the same Act. ${ }^{38}$ The CAF did not deny that its policy of excluding women constituted sex discrimination, but argued that it was justifiable under the Human Rights Act as a bona fide occupational requirement to ensure operational effectiveness. ${ }^{39}$

The Tribunal recognised that the 'principle of operational effectiveness in time of war or national emergency is the fundamental criterion against which the CAF has developed and continually assesses its personnel policies. Operational effectiveness, or combat readiness and preparedness, determines personnel policy, and that policy by logical extension must seek to minimize the risk or hazards to life and limb that combat readiness might, or usually, entails. ${ }^{30}$ The issue is 'whether the occupational requirement is justifiable only if it increases safety by a substantial amount and whether the evidence is sufficient to show that the risk is real and not based on mere speculation. ${ }^{31}$ To guard against the risk of speculation about women's capacities, the Tribunal meticulously considered the factual record. This record included evidence from the SWINTER (Servicewomen in Non-Traditional Environments and Roles) trials which CAF had initiated in

\footnotetext{
$34 \quad$ Karen Rabile, 'Compulsory Military Service and Equal Treatment of Men and Women' (2003) 4 German Law Journal 299; Martin Trybus, 'Sisters in Arms: European Community Law and Sex Equality in the Armed Forces' (2003) 9 European Law Journal 631, 656-657; Beate Rudolf, 'European Union: Compulsory Military Service' (2005) 3 International Journal of Constitutional Law 673.

35 Military Service Act and Home Guard Act (universal military service for women) (Endringer i vernepliktsloven og heimevernloven [allmenn verneplikt - verneplikt for kvinner]) 2013 Prop $122 \mathrm{~L}$ (NW) <https://www.regjeringen.no/nb/dokumenter/Prop-122-L-20132014/id762771/? docId=PRP201320140122000DDDEPIS\&ch=1\&q > accessed 6 January 2015.

Gauthier (n 14) 5.

Ibid 2-4.

Ibid 2.

Ibid.

Ibid 23 .

Ibid 27.
} 
1980 to determine the physical, psychological and social problems that might arise 'if all military occupations were opened to women without restriction of any kind. ${ }^{42}$ The factors that the Tribunal deemed essential for operational effectiveness included physical capability, environmental conditions, social relationships, cohesion, and motivation.

With respect to physical capacities, the Tribunal explained that 'until the recent past, it was widely assumed that women as a class lacked the physical capability for certain jobs which demanded strength or stamina. This stereotype assumption has been set aside in favour of a gender-neutral occupational physical standard in which individuals are, without respect to gender, tested for the specific job demands'. ${ }^{43}$ Based on the evidence from many tests in Canada and beyond, the Tribunal concluded that 'there is no risk based on physical capability to the inclusion of qualified women in presently all-male units and occupations. ${ }^{34}$ The Tribunal also concluded that 'pregnancy was not an issue in the definition of risk to operational effectiveness but simply a matter of temporary "disability" or medical condition for which leave was appropriate. The birth of a child to a servicewoman is not a cause for dismissal from the Forces. ${ }^{345}$

Regarding environmental conditions, the Tribunal concluded that 'the environmental factor in operational effectiveness of mixed units was less significant and less problematic than it had once been, largely because first, it could be 'managed' by minimal structural arrangements in existing facilities, and second, unisex environments and facilities for mixed-gender use are now common in civilian life. ${ }^{36}$ The Tribunal did limit one occupational field, finding that 'privacy constitutes a significant factor in operational effectiveness and the exclusion of women from occupations which serve in submarines exclusively is a bona fide occupational requirement'. ${ }^{47}$ When the privacy concerns were resolved, women started serving in submarines. ${ }^{48}$

On social relationships, the Tribunal addressed CAF's allegation that 'gender adds a complicating element to the performance of individuals and of the group when women are added to an all-male unit'. ${ }^{49}$ The Tribunal explained that 'social factors do not themselves compromise operational effectiveness, where the gender relationships are built on shared commitment to a set of work standards

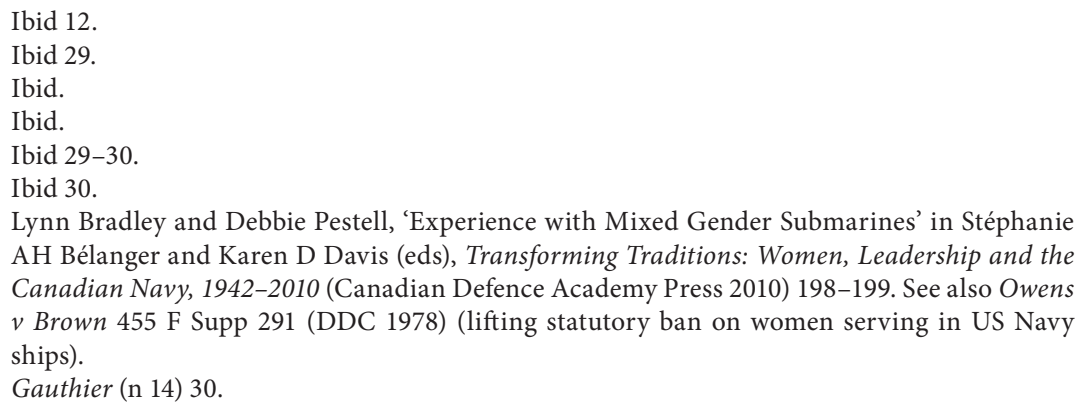


and performance levels, and on shared training. ${ }^{50}$ The Tribunal elaborated that 'education, work experience, leadership, all play a part in removing or modifying stereotypes held by one gender of another, and in this case, particularly held by males in the service about women'. ${ }^{51}$

The Tribunal addressed cohesion as 'an essential ingredient of the drive to reach a goal, to perform well and to die for one another, if necessary'. ${ }^{52}$ The Tribunal found that 'Having considered the evidence at length, we concluded that there was no, or not sufficient evidence of an indisputable kind, to suggest that a mixed gender unit could not develop that cohesion necessary to put in a better than adequate performance. There have been no studies of units during real combat and perhaps never can be. Nevertheless the SWINTER trials ... suggested that the first step to cohesion, social tolerance or acceptance can be managed by good leadership and indeed would develop normally as unit members shared common occupational concerns, experience and training. ${ }^{53}$

Regarding motivation, the Tribunal took the view that 'a variety of motivational elements can be made subject to a management process or will grow out of common service training and experience. No one suggested that women resist discipline any less or more than men, or that those who are determined to succeed have no will. ${ }^{54}$

The Tribunal discussed the historical record of women in all-female or mixed gender units in both regular and partisan forces from various countries, especially during World War II, and concluded that 'the record of women in all female or mixed gender units in both regular and partisan forces ... is reasonably clear. Women fought beside men in combat and combat support units, were armed, suffered both loss of life and limb, inflicted death and injury on others. In short, women were indistinguishable from men in terms of performance. ${ }^{55}$

The Tribunal concluded overall that 'there is no risk of failure of performance of combat duties by women sufficient to justify a general exclusionary policy. Such policy cannot, therefore, constitute a bona fide occupational requirement under the Canadian Human Rights Act. ${ }^{56}$ Since 1989, with the exception of excluding women from submarines, which exclusion was subsequently rescinded, ${ }^{57} \mathrm{CAF}$ excludes neither women nor men from any CAF positions, including combat.

About a decade after Gauthier, Canada's Commonwealth cousin, the UK, argued in Sirdar that it could deny employment to women in the Royal Marines 'by reason of the 'interoperability' rule established for the purpose of ensuring combat

Ibid 31 .

Ibid 30.

Ibid 31 .

Ibid 32 .

Ibid.

Ibid 9-11.

Ibid 34

Bradley and Pestell (n 48) 198-199. 
effectiveness'. ${ }^{58}$ The policy of the Royal Marines excluded women on the ground that 'their presence is incompatible with the requirement of 'interoperability', that is to say, the need for every Marine, irrespective of his specialization, to be capable of fighting in a commando unit'. ${ }^{59}$ The European Community's Equal Treatment Directive requires equal access for women and men to employment, vocational training and promotion, and working conditions. ${ }^{60}$ Upon being made redundant as a female chef in the Royal Artillery, the plaintiff received the offer to join the Royal Marines, subject to the condition of passing the commando training course. The UK rescinded the offer when it realised that the plaintiff was female. The ECJ held that 'the specific conditions for deployment of the assault units of which the Royal Marines are composed, and in particular the rule of interoperability to which they are subject, justified their composition remaining exclusively male'. ${ }^{61}$

Unlike the Gauthier Tribunal, the ECJ did not examine whether the categorical exclusion of women from the Royal Marines was 'necessary and appropriate' to ensure combat effectiveness. ${ }^{62}$ In deferring to the government's determination that exclusion was necessary and appropriate, the ECJ assumed, without questioning, that the male sex is the essential criterion for ensuring combat effectiveness. Had it followed the reasoning in Gautier, it might have required the government, through its military, to establish 'objective standards of competence ... as the universal and ubiquitous reference point for all service personnel, whatever their race, ethnicity, gender, religion, or sexuality. ${ }^{63}$ In the following years, the antipodean Commonwealth cousins, New Zealand ${ }^{64}$ and Australia ${ }^{65}$ have followed Canada's lead in revoking their respective combat exclusion policies, by establishing objective standards of competence irrespective of sex. The UK exclusion policy is currently under review. ${ }^{66}$

In Kreil, the ECJ interpreted the European Community's Equal Treatment Directive to preclude 'the application of national provisions, such as those of German law, which impose a general exclusion of women from military posts involving the use of arms and which allows them access only to medical and

Sirdar (n 15) para 29.

Ibid para 7.

Directive 76/207/EEC.

Sirdar (n 15) para 31.

Ibid para 28; Trybus (n 34) 646-647.

Anthony C King, 'Women in Battle: The Female Solider' (2013) 43(2) Parameters 13, 25.

Human Rights (Women in Armed Forces) Amendment Act 2007 (NZ); Ministry of Defence, 'Maximizing Opportunity for Military Women in the New Zealand Defence Force' (February 2014) <www.nzdf.mil.nz/downloads/pdf/public-docs/2014/maximisingopportunities-military-women-nzdf.pdf > accessed 12 January 2015.

65 Australian Department of Defence, 'Removal of Gender Restrictions from ADF Combat Roles' (August 2013) <www.defence.gov.au/women/ImplementationPlan.asp> accessed 27 January 2015.

66 Joanne Mackowski, 'Women in Combat: British Band of Brothers May Soon be History' (Royal United Services Institute 9 May 2014) <https://www.rusi.org/analysis/commentary/ ref:C536CEF1517EE8/\#.U-jSC7GTKA0> accessed 7 February 2015. 
military-music services'. ${ }^{67}$ The ECJ explained that 'were the contrary view to be adopted, women would continue to be marginalized by being confined to certain sections of the Bundeswehr only - with the risk that the old stereotypical division between the sexes would be perpetuated. ${ }^{68}$ The ECJ ruled that the Equal Treatment Directive does not allow women to be precluded from such employment 'on the ground that public opinion demands that women be given greater protection than men against risks which affect men and women in the same way'. ${ }^{69}$

The ECJ explained that 'the exclusion of women from the Bundeswehr is not restricted to specific units but covers, without distinction, all sections other than the medical and military-music services. ${ }^{70}$ The German government tried to justify its exclusion because all combat units have to be capable of 'interoperable deployment without any distinction between front-line duties (which present a greater risk) and duties behind the lines (which present a lesser risk). ${ }^{71}$ The ECJ did not accept this justification because the interoperability rule applied to all sections, not just, as in Sirdar, to the Royal Marines. Moreover, the Court said that the German authorities, unlike the UK authorities, failed to prove that this rule is actually enforced in all combat units outside the medical and military-music services. ${ }^{72}$ The reaction to Kreil was swift. The German parliament amended its Basic Law to read: 'The [women] may on no account be forced to render services involving the use of arms. ${ }^{73}$

Similar to the Kreil Court's reliance on the facts as a way of addressing gender bias, the European Court of Human Rights held that the discharge of individuals on grounds of their homosexuality from the armed forces was an unjustifiable violation of their right to privacy. ${ }^{74}$ The Court noted that there was a lack of concrete evidence to substantiate the alleged damage to morale and fighting power that any repeal of the ban on homosexuals in the military would entail. ${ }^{75}$ The Court elaborated:

To the extent that they represent a predisposed bias on the part of a heterosexual majority against a homosexual minority, these negative attitudes cannot, of themselves, be considered by the Court to amount to sufficient justification for the interferences with the applicants' rights [of privacy], any more than similar negative attitudes towards those of a different race, origin or colour. ${ }^{76}$

Kreil (n 16) R1 Order.

Ibid para A24.

Ibid paras A13, A23.

Ibid para A27.

Ibid para A27. See also ibid para A14.

Ibid paras A27-A28.

Trybus (n 34) 653.

Lustig-Prean and Beckett $v$ the United Kingdom (1999) ECHR 71; Smith and Grady $v$ the United Kingdom (1999) ECHR 72.

Lustig-Prean (n 74) paras 33, 92.

Ibid para 90. 
The Court explained that 'even if it can be assumed that the integration of homosexuals would give rise to problems not encountered with the integration of women or racial minorities, the Court is not satisfied that the codes and rules [of conduct] which have been found to be effective in the latter case would not equally prove effective in the former. ${ }^{37}$

The Hegar case, currently pending in a US federal district court, alleges that the combat exclusion policy of the US Department of Defense (DoD) violates the constitutional equal protection guarantee. ${ }^{78}$ The plaintiffs, two of whom 'were awarded the Purple Heart after being wounded while serving in combat, ${ }^{79}$ ask the Court to 'require the [DoD] to allow women to apply for all combat related positions and schools and to be considered on their individual merit'. ${ }^{80}$ They explain that 'women - as a class and solely because of their gender - are currently barred from nearly 20 percent of jobs across the active duty force, including all or nearly all positions in the infantry units, armour units, artillery units, reconnaissance units, Special Forces Units and all other units below the battalion level that have direct ground combat as a primary mission. Women are also categorically excluded from combat arms schools, courses, and training programs, such as Ranger School and Special Forces.' ${ }^{81}$ Shortly before the DoD's answer to the complaint was due in court, the combat exclusion policy was revoked. ${ }^{82}$ The case is still pending because the Services have yet to actually integrate women into combat units and positions. ${ }^{83}$

The Amended Complaint contends that the 'categorical exclusion of women from combat units, occupational specialties and schools is based on outdated stereotypes of women and ignores the realities of the modern military and battlefield conditions' ${ }^{84}$ The Complaint explains how the exclusionary policy and practice harm servicewomen in significant ways:

In addition to explicitly prohibiting women from serving in certain positions and career specialties, the DoD's current exclusionary policies put servicewomen at a disadvantage in the promotion process, even within career specialties that are open to women. Formal assignment to combat arms units and positions is an important factor in promotion to leadership positions in the officer corps and among enlisted personnel, particularly in the Army and the Marine Corps. For example, more than 80 percent of the general officers in the Army came from the

\footnotetext{
77 Ibid para 94.

78 Hegar (n 17) paras 1-8. See also Martha E McSally, 'Defending America in Mixed Company: Gender in the US Armed Forces' (Summer 2011) 140 Daedalus 148, 149.

$79 \quad H e g a r(n$ 17) paras 13, 17, 22.

80 Ibid para 8, ibid 'Prayer for Relief' 27, para 2.

$81 \quad$ Ibid para 52.

82 Ibid para 2.

83 Greg Jacob, 'The 'Brass Ceiling' is Still Alive and Well in the US Military' (Defense One 12 November 2014) <www.defenseone.com/ideas/2014/11/brass-ceiling-still-alive-and-wellus-military/98837/?oref=d-river $>$ accessed 7 January 2015. Defense (n 17)

84. Hegar (n 17) para 4.
} 
combat arms, from which women are largely excluded. Chances for promotion to senior enlisted positions are likewise enhanced for those who have served in combat arms positions and career specialties. Further, even in open specialties, servicewomen are prevented from being assigned to as many units as their male counterparts, and these restrictions can limit their ability to gain careerbroadening assignments and attend leadership and other schools. The DoD combat exclusion policy and practice thus serve as a structural barrier to the advancement of women with the Armed Forces. ${ }^{85}$

The Complaint explains that the exclusionary policy and practice imply that women are not capable of serving in the same manner as men, thus relegating them 'literally and figuratively, to a "supporting role" in our Armed Forces based on stereotypes about women and assumptions about battlefield conditions that do not reflect the reality that women, including the individual Plaintiffs, are already serving in combat situations, and doing so with distinction'. ${ }^{86}$ In short, the military should use its basic training period to evaluate potential recruits, and include or exclude them based on their individual performance, not on the premise that all women cannot adequately perform..$^{87}$

The Israeli Supreme Court in Miller and the US Supreme Court in Virginia have addressed exclusion of women from certain kinds of military training. The Israeli Supreme Court held that the Ministry of Defence general exemption of women from aviation courses could not be justified by planning considerations. ${ }^{88}$ A perceptive concurring opinion explained that the harm of deprecating stereotypes is degradation: 'closing a profession or a position to a person because of his sex, race or the like sends a message that the group to which he belongs is inferior, and this creates a perception of inferiority of the men and women in the group. This creates a vicious cycle that perpetuates the discrimination. The perception of inferiority, which is based on the biological ... difference, causes discrimination, and the discrimination strengthens the deprecating stereotypes of the inferiority of the victim of discrimination. Therefore the main element of discrimination because of sex ... is the degradation of the victim. ${ }^{89}$

This same concurring opinion explained that equality 'permits, and even necessitates, different treatment when the "difference" is relevant, but it does not contain criteria for determining that relevance. In the absence of such criteria, there is a danger ... that the criteria applied in each case will reflect the degrading stereotypes which the prohibition of discrimination was originally intended to

\footnotetext{
$85 \quad$ Ibid para 59.

86 Ibid para 63. See also Helen Thorpe, Soldier Girls - The Battle of Three Women at Home and at War (Scribner 2014).

87 Maia Goodell, 'Exclusion of Women from Military Combat Positions' (2010) 34 Seattle University Law Review 17, 33-36.

88 Daphne Barak-Erez, 'The Feminist Battle for Citizenship: Between Combat Duties and Conscientious Objection' (2007) 13 Cardozo J L \& Gender 531, 541-547.

89 Miller para 4 (Dorner J).
} 
prevent. In our case, the prohibition against the discrimination of women is likely to be rendered meaningless by a determination - based on accepted degrading stereotypes - that the difference between women and men justifies, and even necessitates, different treatment of women. ${ }^{90}$

A year after the Miller decision, the US Supreme Court in Virginia overturned a law preventing women from attending an all-male military institute because Virginia had relied on unsubstantiated generalisations about the talents, capacities, or preferences of women that have impeded women's progress toward 'full citizenship stature.." The Court explained that 'generalizations about "the way women are," estimates of what is appropriate for most women, no longer justify denying opportunity to women whose talent and capacity place them outside the average description. ${ }^{\prime 2}$ Similar to the concurrence in Miller, Virginia emphasised the degrading nature of generalisations about women as a class: sex 'classifications may not be used, as they once were ... to create or perpetuate the legal, social and economic inferiority of women. ${ }^{\prime 93}$

With the exception of the Rostker and Dory decisions on the exclusion of women from the draft and the Sirdar interoperability decision, the exclusion decisions stand for the proposition that women can no longer be categorically excluded from the military, its particular operations or its training. Women must be given the opportunity to prove they can meet objective standards of military performance. Gauthier meticulously analysed the facts about women's capabilities to find generalisations about women's physical, emotional and cognitive inabilities to serve in combat roles to be unsubstantiated. In so finding, the decision contributed to the dismantling of prejudices of women as incapable of being combatants or successfully completing military institutes or training programmes.

The exclusion decisions did not elaborate on the sex role stereotypes and gender prejudices. The sex role stereotype of men is that they are and should be warriors and military leaders. The prejudice about women is that they do not have the capacities to be warriors and military leaders and as a result should be limited to support roles. The hesitancy to analyse the stereotypes and prejudices might be due to a lack of awareness of the gender dimensions of the military. It has been explained that 'military organizations and war itself [are] inherently gendered and "naturally" masculine, so that women are seen as fundamentally not suited to soldiering and warfare. ${ }^{\text {'94 }}$ Militaries 'construct, rely on, and perpetuate beliefs

Ibid para 6 (Dorner J).

Virginia (n 19) 533 (Ginsburg J).

Ibid 550 .

Ibid 534.

Mathers (n 8) 124. See also Valorie K Vodjik, 'Beyond Stereotyping in Equal Protection Doctrine: Reframing the Exclusion of Women from Combat' (2005) 57 Alabama LR 303, 341-349. 
about gender, and they depend on women and men to accept, internalise, and act on those beliefs'. ${ }^{95}$

The exclusion cases discussed the individual and group harms to include marginalisation and degradation of women, disadvantaging them in their military careers, and denying them their full citizenship. Miller, Virginia, Kreil and the dissent in Rostker all pointed to individual and group harms of gender classifications. Virginia specified that gender classifications 'may not be used, as they once were ... to create or perpetuate the legal, social and economic inferiority of women.' Miller explained that the harm of deprecating stereotypes is 'degradation'.

The Hegar complaint perceptively addressed the effects of the combat exclusion policy on women's inability to rise to the top levels of military leadership. ${ }^{96}$ The complaint explained that currently 'more than 80 percent of the general officers in the Army came from the combat arms'. The dissent in Rostker and the majority in Virginia specified the harm of exclusion policies limiting women's chances of becoming civilian leaders. ${ }^{97}$ The Virginia majority eloquently explained that the Virginia Military Institute's exclusion policies impeded women's progress toward 'full citizenship stature', challenging the assumption that men's 'military service defines citizenship. ${ }^{98}$

\subsection{UNEQUAL TREATMENT CASES}

Equal treatment of men and women is essential for gender-integration to be effective in the military. Court decisions that address stereotypes embedded in unequal treatment by the military include those on the discharge of pregnant military personnel (Struck, Crawford), the unequal treatment of dependents of female military personnel (Frontiero), and denying military men parental leave on an equal basis with military women (Markin).

In Struck, a US Court of Appeals held that the Air Force regulation providing for the discharge of pregnant officers did not deny liberty or property without due process, equal protection or right to privacy. Captain Struck appealed this decision to the US Supreme Court, but because the Air Force thought its chances of success were slim, it agreed to waive her discharge and abandon its policy of automatically discharging its pregnant personnel. ${ }^{99}$

\footnotetext{
$95 \quad$ Mathers (n 8) 124.

96 Emerald M Archer, 'The Power of Gendered Stereotypes in the US Marine Corps' (2012) 39 Armed Forces and Society 359.

97 Nancy Levit, 'Feminism for Men: Legal Ideology and Construction of Maleness' (1995-1996) 43 UCLA Law Rev 1037, 1059; Ellen Symons, 'Under Fire: Canadian Women in Combat' (1990-1991) 4 Canadian Journal of Women and Law 477, 507.

$98 \quad$ Catherine A MacKinnon, Toward a Feminist theory of State (HUP 1989) 224.

99 Neil S Siegel and Reva B Siegel, 'Struck by Stereotype: Ruth Bader Ginsburg on Pregnancy Discrimination as Sex Discrimination’ (2009-2010) 59 Duke L J 771, 778.
} 
Consistently with Gauthier's treatment of pregnancy as a temporary disability, ${ }^{100}$ a US Court of Appeals in Crawford found that a US Marine Corps regulation that mandated the discharge of female Marines for pregnancy was unconstitutional. The Court reasoned that the distinction between pregnant personnel and other personnel with other temporary disabilities was irrational. The Court determined that the 'regulation as a tool for insuring mobility and readiness is applied in a manifestly underinclusive fashion. As the District Court found, at the time of appellant's discharge, pregnancy was the lone disability subjected to the rather drastic treatment. The Marine Corps left all other temporary disabilities, which undeniably undermined the ability of all personnel to respond like quicksilver to duty's call, free from the mandatory discharge "solution". ${ }^{101}$ The Court stated that: "In short, we can regard the regulation here only as one based on unsubstantiated generalizations about the sexes, in the class of those 'archaic and overbroad' premises which have been rejected as unconstitutional'. The Court continued: 'Not the least of these outmoded generalizations are the taboos inherent in connection with pregnancy, whether as a result of Victorian embarrassment at its physical capacity or as a presumption of physical incapacity.' ${ }^{102}$

Both Struck and Crawford challenged the presumption embedded in military regulations that pregnant women as a group, and without regard to their individual capacities for service during pregnancy, are unfit for service. This presumption subordinated pregnant women as a group because they were assessed as a class of pregnant women, rather than on the basis on their individual fitness to serve. Moreover, women in the military were supposed to fit into 'the stereotypical vision ... of the "correct" female response to pregnancy.'103 These pregnancy regulations "prohibited the employment of officers who became mothers, while allowing the employment of officers who became fathers,' 104 thus constraining women's family life while privileging men's. As a result, 'mandatory pregnancy discharge reinforces societal pressure to relinquish career aspirations for a hearth-centered existence.' ${ }^{105}$

The Frontiero and Markin decisions dismantled the sex role stereotypes of men as breadwinners and women as dependent homemakers in the military sector. Frontiero concerned a female military member's right to create automatic entitlements (such as increased housing allowances and medical and dental benefits) for her husband that a military husband already could provide for his wife. The US Supreme Court found that a federal law allowing wives of male military members automatically to become dependents, while husbands of

Gauthier (n 14) 45.

Crawford (n 21), para 24.

Ibid para 30.

Siegel and Siegel (n 99) 780, quoting from the Ginsburg brief in Struck (n 20).

Ibid.

Ibid. 
female military members were not considered dependents unless they relied on their wives for over one-half of their income support, violated the due process guaranty. In so finding, the Court enabled women to be providers in the military sector.

Frontiero explained that laws that restrict women's rights have historically been rationalised as benign protections of women, in that wives were afforded protection of their husbands' support that wives could not afford their husbands. The Court elaborated that the nation's 'long and unfortunate history of sex discrimination' was 'traditionally ... rationalized by an attitude of "romantic paternalism" which in practical effect, put women not on a pedestal, but in a cage.' ${ }^{106}$ Due to notions of benign paternalism, the Court explained, 'our statute books gradually became laden with gross, stereotyped distinctions between the sexes'. ${ }^{107}$ The Court continued:

what differentiates sex from such non-suspect classes as intelligence or physical disability, and aligns it with the recognised suspect criteria, is that the sex characteristic frequently bears no relation to ability to perform or contribute to society. As a result, statutory distinctions between the sexes often have the effect of invidiously relegating the entire class of females to inferior legal status without regard to the actual capabilities of its individual members. ${ }^{108}$

In Markin, the Grand Chamber of the European Court of Human Rights (ECtHR-GC) held that the exclusion of servicemen from entitlement to parental leave, while servicewomen are so entitled, amounted to sex discrimination in family life. The ECtHR-GC addressed the decision of the Constitutional Court of Russia holding that the Military Service Act granting female military members three years of parental leave, while granting their male military colleagues only three months special leave to arrange for childcare, was constitutionally compliant. ${ }^{109}$ In rejecting the request for parental leave, the Constitutional Court did not envision a need to accord men a better way to balance the demands of family life and military work. The Constitutional Court said: the 'purpose of such a leave is to give the serviceman a reasonable opportunity to arrange for the care of his child and, depending upon the outcome, to decide whether he wishes to continue the military service. If the serviceman decides to take care of his child himself, he is entitled to early termination of his service for family reasons'. ${ }^{110}$ The Constitutional Court explained that the legislature took account of the limited

Frontiero (n 22) 684 (Brennan J).

Ibid 685 .

Ibid 686-687.

Markin (n 23), para 34.

Ibid (citing para 2.2 of the Russian Constitutional Court decision of 15 January 2009). 
participation of women in the military and the special role of women associated with motherhood. ${ }^{111}$ The applicant responded:

Far from mitigating any historic disadvantage suffered by women, a policy whereby only women were entitled to take parental leave perpetuated gender stereotypes, inequality and hardship arising out of women's traditional role of caring for the family in the home rather than earning money in the workplace. As a result, that policy discriminated both against men (in family life) and against women (in the workplace). ${ }^{112}$

In finding a breach of the right to non-discrimination on grounds of sex in relation to family life, the ECtHR-GC concluded that: 'traditional distribution of gender roles in society cannot justify the exclusion of men, including servicemen, from entitlement to parental leave. ${ }^{313}$ It explained:

gender stereotypes, such as the perception of women as primary child-carers and men as primary breadwinners, cannot, by themselves, be considered to amount to sufficient justification for a difference in treatment, any more than similar stereotypes based on race, origin, colour or sexual orientation. ${ }^{114}$

In enabling military men to take parental leave (as opposed to 'special leave'), the Court dismantled the myth of men as inadequate parents and began to build a norm of men as nurturers. ${ }^{115}$

A concurring opinion would have also found discrimination on the ground of military status, because servicemen were treated less favourably than civilian men, since the latter were entitled to parental leave. The concurrence explained that no factual evidence was presented of any risk to operational effectiveness of the armed forces due to the possible parental leave taken by servicemen. ${ }^{116}$

The unequal treatment decisions explicate the prejudicial nature of military regulations with regard to pregnancy and parental leave and dependency benefits. They name the stereotypes, discuss their individual and group harms and explain why generalisations violate military women's rights. Markin's naming of the sex role stereotypes of men as breadwinners and women as homemakers shows how such stereotypes unjustifiably denied Mr Markin, and other similarly situated men, parental leave and thus infringing their family life in the military sector. Frontiero explains the harms of the stereotypes of military women as a group: invidiously relegating the entire class of females to inferior legal status without

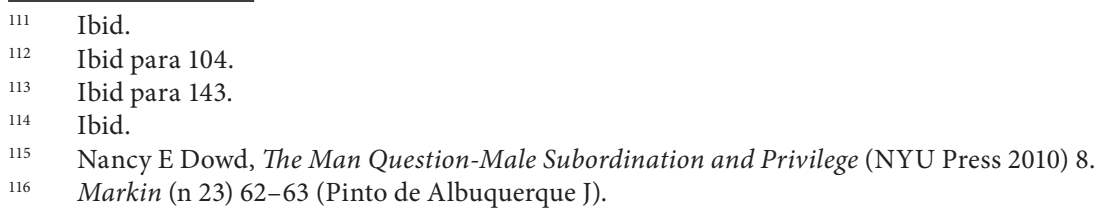


regard to the actual capabilities of its individual members.' Crawford determined that the generalisations about pregnant women were 'unsubstantiated' and 'underinclusive' because pregnancy was the only temporary disability subject to discharge. The courts showed how sex role stereotypes deny military men the equal benefits of family life and how generalisations about military women are under-inclusive, thus obstructing their military careers. In so doing, the courts have enabled military personnel, irrespective of gender, to enjoy family life consistently with their military duties.

\subsection{SEXUAL ASSAULT CASES}

This section addresses pending and decided cases on sexual harassment, assault and rape by male military personnel of their military comrades (Gallagher), and by male military personnel of civilian women (Rodríguez Bustamente, Fernández Ortega).

The Gallagher case against the US is pending before the Inter-American Commission on Human Rights on behalf of 20 military personnel (17 women and 3 men) who had been subjected to sexual violence, in most cases rape, by their military comrades. In ignoring petitioners' subjection to sexual assaults and in overlooking the retaliation against them for reporting the assaults, the case alleges that the US violated petitioners' rights under the American Declaration of Human Rights to life and security of the person, to be free of inhumane treatment, to privacy and protection of honour and reputation, to special protection, and to inviolability of the home. The case further claims that the US failure to investigate petitioners' complaints and provide them with appropriate remedies violated their rights under the American Declaration to equal protection before the law on the basis of military status, gender and sexual orientation, and their rights to truth, to resort to the courts, and to petition the government and receive a prompt decision. ${ }^{117}$

The claim alleges violations of the right to work for all the petitioners who experienced sexual harassment in the workplace and for those petitioners who had to leave the military because of, for example, physical injuries, military sexual trauma-related post-traumatic stress disorder (PTSD), and being discharged under the 'Don't Ask Don't Tell' policy on sexual orientation. ${ }^{118}$

Consistently with the Commission's previous decision that military justice systems, including investigations and trials, are considered ineffective remedies to address human rights violations, ${ }^{119}$ the petition requests that:

\footnotetext{
117 Gallagher (n 24) 47-65, 69-77.

118 Ibid 10, 18, 20, 22, 66-69.

119 IACtHR, Márcio Lapoente da Silveira v Brazil, Case 4524-02 Report No 74/08, OEA/Ser L/V/ II 130 Doc 22, rev 1 (2008), para 64.
} 
- the decision whether to investigate, prosecute, and punish alleged perpetrators be removed from the military Chain of Command;

- an independent reporting procedure is established to encourage victims to come forward without fear of reprisal from their Chain of Command; and

- victims have access to US federal courts so they may sue for civil relief when the US Military violates their human and United States constitutional rights, which they are currently unable to do under US law. ${ }^{120}$

The petition requests that the US Uniform Code of Military Justice be amended to include provisions that prevent retaliation, prohibit prosecuting perpetrators of sexual violence with adultery instead of the more appropriate charge of rape, and prohibit punishing perpetrators of sexual violence under lesser provisions on non-judicial punishment, such as docking the perpetrators' pay. Ultimately, the petitioners seek an Advisory Opinion from the Inter-American Court of Human Rights regarding the nature and scope of the US obligations under the American Declaration in light of the Inter-American Convention on the Prevention, Punishment and Eradication of Violence against Women and the Convention on the Elimination of All Forms of Discrimination against Women. ${ }^{121}$

The complaint explains how the petitioners in basic training were described as: 'weak or incompetent,' 122 'bitch, pussy, fag or a cunt', ${ }^{123}$ or how the petitioners who reported rape were labelled as 'trouble makers', ${ }^{124}$ 'difficult', ${ }^{125}$ 'liars', ${ }^{126}$ 'whores', ${ }^{127}$ or 'sluts'. ${ }^{128}$ Such hostile labelling often takes place when an out-group joins an in-group. ${ }^{129}$ When left unchecked, such degradation contributes to a culture of impunity that encourages sexism and misogyny, ${ }^{130}$ and 'condones a culture that allowed sexual harassment, sexual assault and rape.'131

The complaint explains that the consequences of military sexual trauma are multiple, including PTSD. The complaint elaborates that:

According to Department of Veterans Affairs ... statistics, in 2012, 85,000 veterans sought treatment for military sexual trauma. One study of female veterans found that those with military sexual trauma had higher rates of PTSD than those

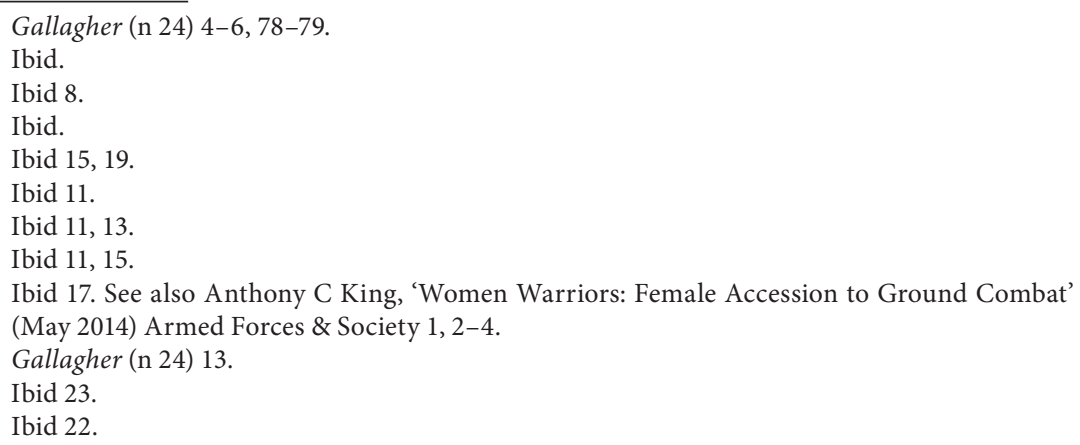


who had experienced other forms of trauma. Sixty percent of those who had experienced military sexual trauma suffered from PTSD. ${ }^{132}$

Yet despite these higher rates, disability claims for military sexual trauma-related PTSD for both women and men are granted at significantly lower rates than other PTSD claims. ${ }^{133}$ Litigation regarding this unequal treatment is pending. ${ }^{134}$

Sexual violence and rape by male military personnel extend to the civilian population, for example rapes of Somali women and girls by the African Union military force. ${ }^{135}$ Much of it happens with impunity, as was the case in Kenya where British male military personnel sexually violated Kenyan women. Despite calls by Amnesty International ${ }^{136}$ and by the Kenyan Truth, Justice and Reconciliation Commission ${ }^{137}$ for investigation, neither the British nor the Kenyan governments have established commissions of inquiry, suggesting that women's sexual bodies are expendable and crimes against women are lesser crimes that do not warrant state investigation. ${ }^{138}$ In contrast, the Colombia Council of State in Rodríguez Bustamente held its military accountable for sexual violations of civilian women. Where national courts have not held militaries responsible for sexual violence by military personnel against civilian women, international tribunals, such as the Inter-American Court of Human Rights in the Fernández Ortega decision, have done so.

$132 \quad$ Ibid 37.

133 American Civil Liberties Union, American Civil Liberties Union of Connecticut, Service Women's Action Network, Yale Law School Veterans Legal Service Clinic, 'Battle for Benefits: VA Discrimination Against Survivors of Military Sexual Trauma’ (November 2013) <aclu. org/womens-rights/battle-benefits-va-discrimination-against-survivors-military-sexualtrauma> accessed 24 January 2015.

${ }_{134}$ Service Women's Action Network, American Civil Liberties Union and American Civil Liberties Union of Connecticut v US Department of Defense and Department of Veteran's Affairs Civil Action No: 3: 10-cv-1953 (SPU) (April 2013) <https:/www.aclu.org/womensrights/service-womens-action-network-v-department-defense> accessed 24 January 2015; Service Women's Action Network and Vietnam Veterans of America v Sloan D Gibson (Second Petition for Review, 28 July 2014) <www.law.yale.edu/documents/pdf/Clinics/vlsc_SWAN_ SecondPetionReview_July_29_2014.pdf > accessed 5 February 2015; 'Military Sexual Trauma Rulemaking and Litigation' <www.law.yale.edu/academics/18333.htm> accessed 5 February 2015.

135 Human Rights Watch, 'The Power These Men Have Over Us: Sexual Exploitation and Abuse by African Union Forces in Somalia' (2014) <www.hrw.org/sites/default/files/reports/ somalia0914_ForUploadR.pdf> accessed 10 February 2015.

136 Amnesty International, 'Decades of Impunity: Serious Allegations of Rape of Kenyan Women by UK Army Personnel' (2003) <www.amnesty.org/en/library/asset/EUR45/014/2003/en/ f72561dd-d6c0-11dd-ab95-a13b602c0642/eur450142003en.html> accessed 21 January 2015.

137 Kenyan Truth, Justice and Reconciliation Commission, 'Report of the Truth, Justice and Reconciliation Commission' (2013) vol IIC ch 1, para $227<$ http://nisisikenya.com/ wp-content/uploads/2013/06/TJRC_report_Volume_2C.pdf> accessed 24 January 2015; Kenyan Truth, Justice and Reconciliation Commission, 'Report of the Truth, Justice and Reconciliation Commission' (2013) vol IV ch 1, 32, 36, 64 <http://nisisikenya.com/wp-content/ uploads/2013/06/TJRC_report_Volume_4.pdf > accessed 24 January 2015. 
In Rodríguez Bustamente, the Colombian Council of State ordered the National Ministry of Defence to pay moral damages to the young victim, Mónica Marisol Rodríguez Bustamente, her mother and three siblings, damages to Ms Mónica for harm to her life plan, payment for her psychotherapeutic treatment, and damages to compensate her for loss of profits and other material harms. Finally, in order to achieve full reparation and non-repetition, the Council ordered non-pecuniary measures, such as dissemination of its decision to relevant governmental bodies for adoption of preventative and corrective measures, training programmes in women's rights, including of women affected by internal armed conflict, for the national army in the area where this violation took place, and the development of guidelines for the military for the prevention, investigation and punishment of violence against women. ${ }^{139}$ The Council of State called for the prevention of gender prejudice and stereotyping, such as in the treatment of women as the sexual property of men, and the biased treatment of women in investigations and prosecutions. ${ }^{140}$

The Inter-American Court of Human Rights in Fernández Ortega held Mexico responsible for the rape of an indigenous woman, Mrs Fernández Ortega, by military personnel. The Court found that this rape entailed a violation of her right to personal integrity constituting an act of torture, ${ }^{141}$ her rights to personal integrity and dignity, and to private life, ${ }^{142}$ and an abusive interference with her family residence. ${ }^{143}$ Because the state did not act with due diligence in the investigation of the rape, the Court found a violation of her rights to judicial guarantees and to judicial protection. ${ }^{144}$ Moreover, because of Mrs Fernández Ortega's inability to file a claim in her own language, the Court found unequal treatment in her access to justice. ${ }^{145}$ It also held that the rape and the facts related to the pursuit of justice, and the perpetrator's impunity, involved a violation of the right to personal integrity of her husband and children. ${ }^{146}$ While the Court did not expose the operative stereotypes, its decision helped to overcome the prejudice against indigenous people as lesser citizens by finding a violation of the right to equal access to justice of Mrs Fernández Ortega and her immediate family.

Consistently with its previous rulings, ${ }^{147}$ the Court held that the military justice system does not have jurisdiction to determine whether its military personnel violated the human rights of civilians, because of the lack of independence and impartiality within the system. ${ }^{148}$ It ordered appropriate changes in the Mexican

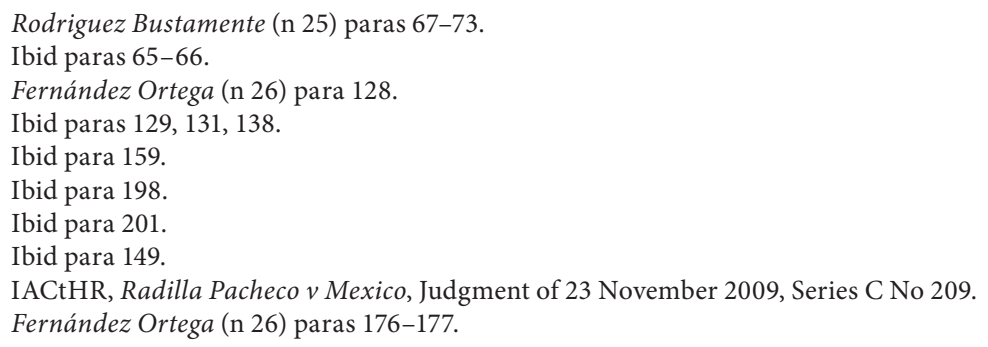


Code of Military Justice, ${ }^{149}$ and establishment of procedures to contest the inappropriate intervention of the military justice system. ${ }^{150}$

In ordering pecuniary and non-pecuniary damages, the Court emphasised the need to continue with the federal and state training programmes on the diligent investigation of sexual violence against women, applying a gender and ethnicity perspective by governmental officials who are the first responders to female victims of violence. ${ }^{151}$ The Court further asked the state to implement a training programme on human rights for all members of the Mexican Armed Forces. ${ }^{152}$ Research is needed to determine whether these training programmes have been undertaken and whether they are effective in dismantling patriarchal structures, such as the socio-cultural practices of gender including hostile gender stereotyping, in order to achieve women's equality. ${ }^{153}$

Militaries are realising that they have to be far more effective in preventing and remedying sexual assault. ${ }^{154}$ Failure to do so will spur further litigation against them, exacerbating reputational and budgetary costs and compromise operational effectiveness. Explanations about the prevalence and persistence of sexual violence in the military abound, including lack of military leadership, ${ }^{155}$ tolerance of an unprofessional work environment, hypermasculinity, ${ }^{156}$ power dynamics, ${ }^{157}$ rigid sex roles and hostility toward women who transgress gender boundaries. ${ }^{158}$ Elaboration of these and other explanations is beyond the scope of this chapter, except to say that more research is needed on how military policies and practices spawn prejudices and degrading stereotyping that can facilitate sexual violence.

\footnotetext{
$149 \quad$ Ibid paras 178, 179, 239.

150 Ibid para 240.

151 Ibid para 260.

152 Ibid para 262.

$153 \quad$ Ibid para 79.

154 Chief of Army Lieutenant General David Morrison, 'Speech' (United Nations International Women's Day Conference, New York, 8-9 March 2013) <www.army.gov.au/Our-work/ Speeches-and-transcripts/United-Nations-International-Womens-Day-Conference> accessed 8 February 2015; Chief of Army Lieutenant General David Morrison, 'The standard you walk past is the standard you accept...' (12 June 2013) <https://www.youtube.com/ watch?feature=player_embedded\&v=QaqpoeVgr8U $>$ accessed 8 April 2015; Edith M Lederer, 'Congo military leaders sign pledge to combat rape in war' Washington Post (Washington, 31 March 2015); Marie Deschamps, 'External Review into Sexual Misconduct and Sexual Harassment in the Canadian Armed Forces' (27 March 2015) <www.forces.gc.ca/en/cafcommunity-support-services/external-review-sexual-mh-2015/culture-caf.page> accessed 4 May 2015.

155 Australian Human Rights Commission, 'Review into the Treatment of Women in the Australian Defence Force, 2012’ (2012) <www.humanrights.gov.au/defencereview> accessed 12 January 2015, 310.

156 Ibid 306

157 Elizabeth L Hillman, 'Front and Center: Sexual Violence in US Military Law' (2009) 37(1) Politics \& Society 101, 103, 114, 116, 119.

158 Jessica Turchik and Susan Wilson, 'Sexual Assault in the US Military: A Review of the Literature and Recommendations for the Future' (2010) 15 Aggression and Violent Behavior $268,270-272$.
} 
Lessons from these cases are preliminary because one case is pending and only two decided cases are discussed. The explication of the degrading labelling, whether it concerns professional competence, sexuality, or truthfulness in the Gallagher brief and the naming of women as the 'sexual property of men' in Rodríguez Bustamente, illuminate the prejudices about women. The hostile labelling suggests that women are less than human, justifying their sexual assaults. Moreover, in failing to adequately address such assaults, the military is sending a message that it is permissible to ignore women's individual values. In delivering justice for Mrs Fernández Ortega and her family, the Inter-American Court overcame prejudices against indigenous people as lesser citizens. In so doing, the Court ensured that individuals, regardless of their sex and, for example, their indigenous status, 'should be able to rely on a [legal] system free of myths and stereotypes, and judiciary whose impartiality is not compromised by ... biased assumptions.' ${ }^{\text {159 }}$

\section{CONCLUSION}

Where women take on warrior and leadership roles that have traditionally belonged to men, hostile stereotyping emerges to keep women out of, invisible in, or relegated to support roles in, the military rather than embraced by it. This phenomenon is not unique to the military. When women joined other professions, such as law, ${ }^{160}$ medicine, ${ }^{161}$ and religious ministries, ${ }^{162}$ hostile stereotyping emerged, and with the help of courts, has been or begun to be addressed. ${ }^{163}$ As female participation in defence forces grows (approximating 9\% in the UK, $12 \%$ in the US, $13 \%$ in Australia, and $17 \%$ in Canada $)^{164}$ militaries will have to address hostile gender stereotyping to ensure that professional competence, irrespective of gender, is given priority. ${ }^{165}$

The lessons learned from this analysis of select court cases on women's exclusion from the military, the unequal treatment of women and men, and sexual assault, are multiple. Courts' deference to presumptions constituting military expertise, evident in Rostker, Dory and Sirdar, is being replaced by

$159 \quad R v$ Ewanchuk [1999] 1 SCR 330 (Supreme Court of Canada) para 95 (L'Heureux-Dubé J).

160 Cook and Cusack (n 1) 34, 127, 163; Simone Cusack, 'Eliminating Judicial Stereotypingequal access to justice for women in gender-based violence cases' (UN Office of the High Commissioner for Human Rights 2014) <www.ohchr.org/EN/Issues/Women/WRGS/Pages/ GenderStereotypes.aspx $>$ accessed 5 February 15.

161 Cook and Cusack (n 1) 20, 34.

162 Jane Kramer, 'A Canterbury Tale - the Battle within the Church of England to Allow Women to be Bishops' The New Yorker (New York, 26 April 2010) 47.

163 Cook and Cusack (n 1) 96.

164 Australian Human Rights Commission (n 155) 187.

165 Christopher Dandeker, 'Selling Army 2020: The British Army and society after the wars of 9/11' (commissioned by the Chief of the General Staff of the Army, Sir Peter Wall, 9 May 2014) $15,33-38,42$ (on file with authors). 
fact-based assessments, as was meticulously done in Gauthier. The fact that the US Department of Defense did not appeal the Hegar case suggests that the Department understood that it would not have been able to substantiate the generalisations about women's inability to meet combat standards in part because, as the complaint explains, women have successfully served in combat as acknowledged by combat decorations awarded by the military to women.

As to the debate about whether claims involving the human and constitutional rights and obligations of military personnel should be litigated in the military or the civilian justice system, all the cases analysed in this chapter were brought in the civilian system. The Gallagher complaint, pending before the Inter-American Commission on Human Rights, exhausted all remedies before both the US military and civilian systems to no avail, as did the complaint in Fernández Ortega in the Mexican systems. To better overcome gender prejudice and to eliminate detrimental gender stereotypes, further research is necessary of military laws and policies and court judgments about equal treatment of men and women in the military, similar to analyses of civilian law. ${ }^{166}$

In the unequal treatment and the sexual assault cases, the naming of the hostile stereotypes was well done in part because consciousness had already been raised about the prejudices in those issue areas outside the military. In the exclusion decisions, stereotypes were less well articulated in part because consciousness had not been raised. Moreover, '[w] hen one sex is disproportionately represented, there is a danger of seeing this as some naturally occurring pattern, rather than questioning the socially constructed norm. Asking why there is disproportion is critical, as well as how that informs the structure and goals of the system.' ${ }^{167}$

The judicial exposition of harms of stereotyping, as was pointedly done in Miller, is essential: 'The presence of unacknowledged harms means a silencing that harms individuals and their relationships, and their communities.'168 The individual and group harms of stereotypic generalisations varied according to kinds of decisions discussed in this chapter. Exclusion cases addressed unsubstantiated generalisations, while the unequal treatment decisions focused on under-inclusive generalisations. Sexual harassment cases exposed false stereotyping. How well courts articulate the individual and group harms, and explain how they violate human and constitutional rights, matters. Legal language shapes and reinforces social meaning. Courts are playing a critical role by articulating how the substitution of individual assessment for inappropriate stereotypes denies the military and civil society, more generally, particular capacities of both men and women.

\footnotetext{
166 UK Judicial College, Equal Treatment Bench Book (2013) <www.judiciary.gov.uk/wp-content/ uploads/JCO/Documents/judicial-college/ETBB_all_chapters_final.pdf $>$ accessed 9 February 2015).

167 Dowd (n 115) 9-10.

168 Dowd (n 115) 10.
} 

